\title{
TRANSFORMAÇÕES DA AGRICULTURA NO ESTADO DE SANTA CATARINA, 1920-1985
}

\author{
EVELISE NUNES DO ESPÍRITO SANTO
}

Orientador: Profa. ZILDA PAES DE BARROS MATTOS

Tese apresentada à Escola Superior de Agricultura

"Luiz de Queiroz", Universidade de São Paulo, para obtenção do título de Doutor em Ciências, Área de Concentração: Economia Aplicada.

P I R A C I C A B A

Estado de São Paulo - Brasil

Janeiro - 1998 
Dados Internacionais de Catalogação na Publicação (CIP) DIVISÃO DE BIBLIOTECA E DOCUMENTAÇÃO - Campus "Luiz de Queiroz"/USP

\section{Espirito Santo, Evelise Nunes do}

Transformaçōes da agricultura no Estado de Santa Catarina, 1920-1985 / Evelise Nunes do Espirito Santo. - - Piracicaba, 1998.

198 p. : il.

Tese (doutorado) - Escola Superior de Agricultura Luiz de Queiroz, 1998.

Bibliografia.

1. Desenvolvimento agricola 2. Inovação tecnológica 3. Modernização agricola 4. Planejamento econômico 5. Propriedade rural 6 . Trabalhador rural 1. Título 


\section{TRANSFORMAÇÕES DA AGRICULTURA NO ESTADO DE SANTA CATARINA, 1920-1985}

EVELISE NUNES DO ESPÍRITO SANTO

Aprovada em: 20.03.1998

Comissão julgadora:

Profa. Dra. Zilda Paes de Barros Mattos

ESALQ/USP

Prof. Dr. Rodolfo Hoffmann

ESALQ/USP

Prof. Dr. Carlos José Caetano Bacha

ESALQ/USP

Prof. Dr. José Juliano de Carvalho Filho

FEA/USP

Dr. Dirceu João Duarte Talamini

EMBRAPA/SC

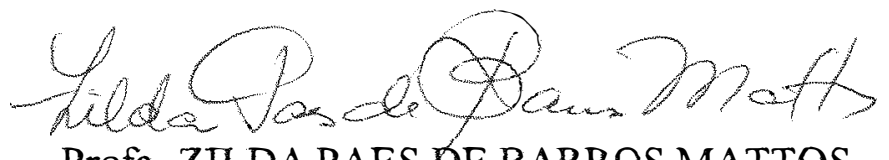

Profa. ZILDA PAES DE BARROS MATTOS

Orientadora 


\section{AGRADECIMENTOS}

À Profa. Dra. Zilda Paes de Barros Mattos, pela criteriosa orientação que possibilitou a realização deste estudo;

Ao Prof. Dr. Rodolfo Hoffmann, pela prestimosa co-orientação e sugestões à metodologia e resultados do estudo;

Ao Prof. Dr. Carlos José Caetano Bacha, pelas críticas e sugestões apresentadas;

Ao Analista de Sistemas, Marcelo Corrêa Alves (CIAGRI/USP) pela colaboração na parte computacional do estudo;

Ao Engenheiro Agrônomo Francisco Roberto Carvalhaes do Espírito Santo (EPAGRI/SC), pelo fornecimento de parte da bibliografia sobre o Estado de Santa Catarina;

Aos colegas, professores e funcionários do Departamento de Economia e Sociologia Rural pelo convívio e troca de conhecimentos. 


\section{SUMÁRIO}

Página

LISTA DE MAPAS ........................................................................... vii

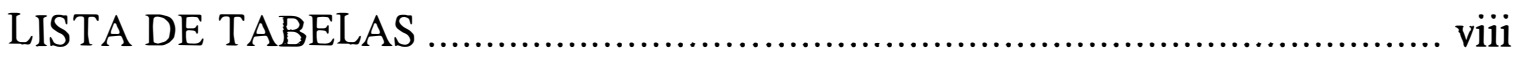

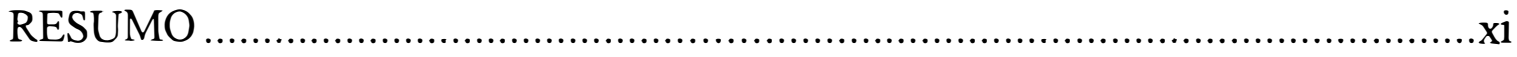

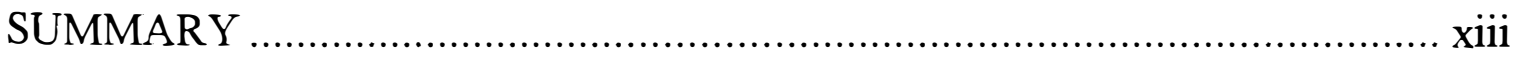

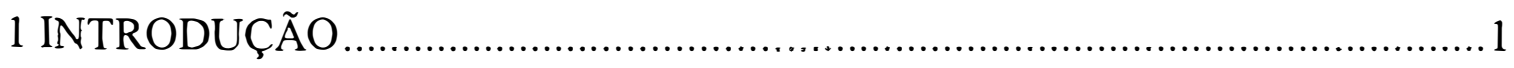

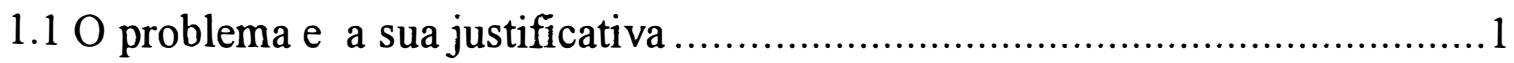

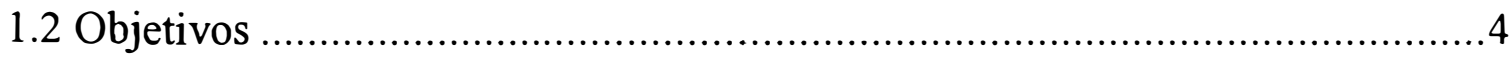

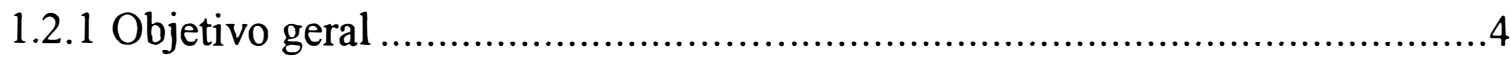

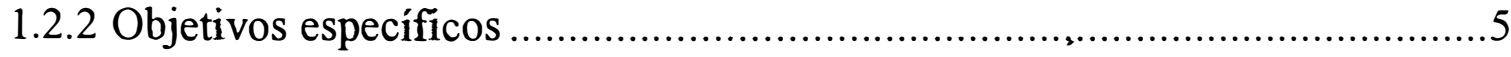

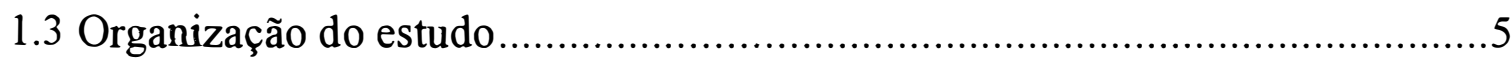

2 MODERNIZAÇÃO DA AGRICULTURA ...............................................6

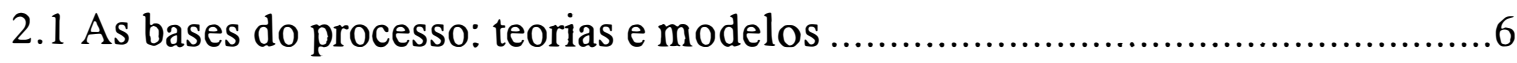

2.2 Conseqüências gerais da modernização ................................................... 15

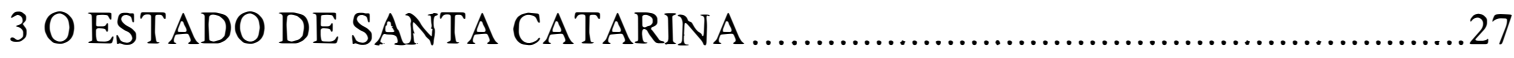

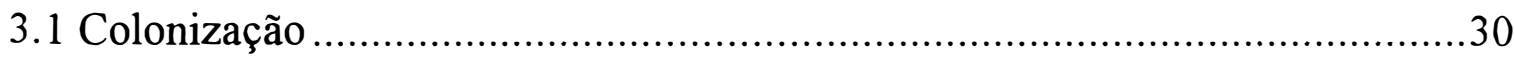

3.2 A modernização da agricultura em Santa Catarina ...................................... 42

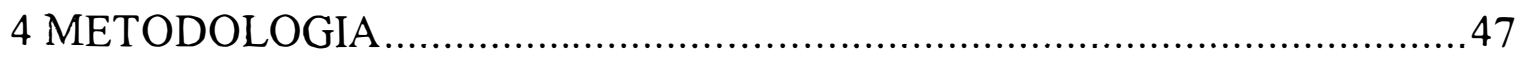

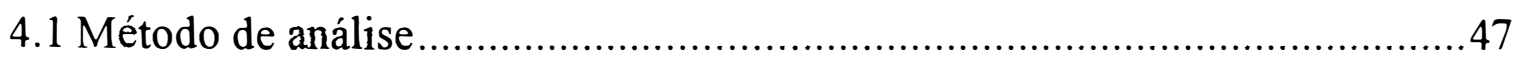

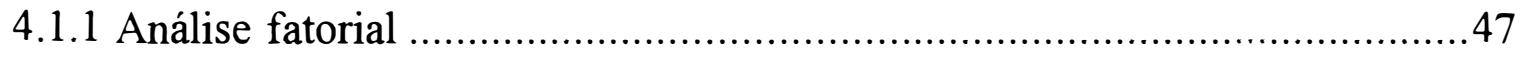

4.1.1.1 Variáveis utilizadas na análise fatorial .............................................51

4.1.2 Medidas do grau de concentração da posse da terra ................................62

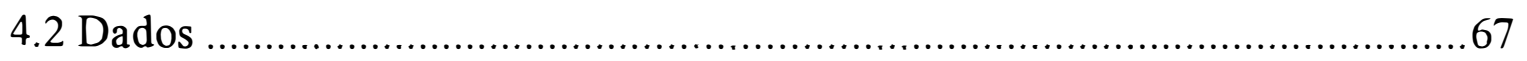

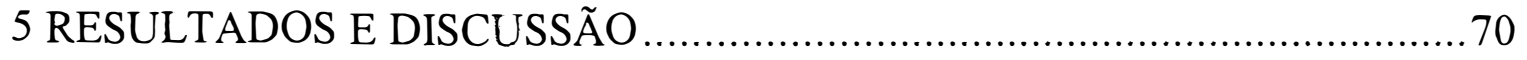

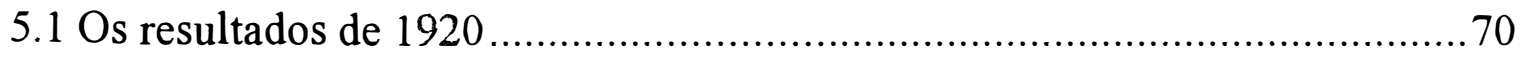




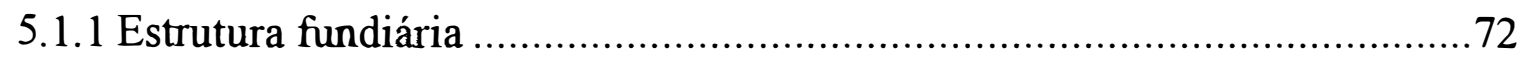

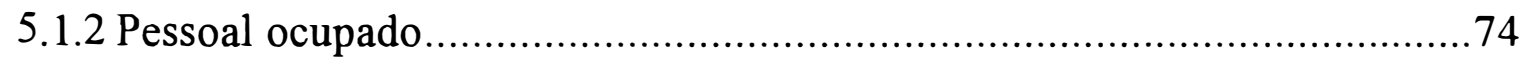

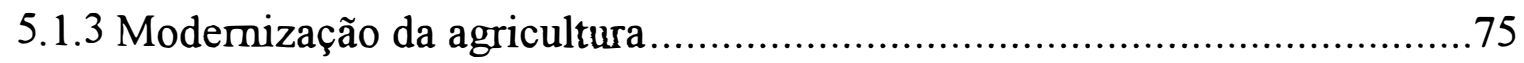

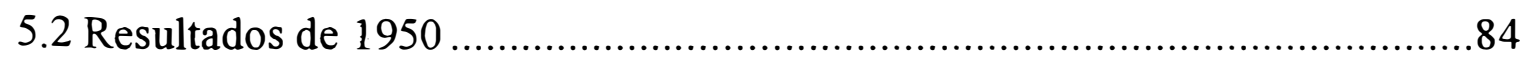

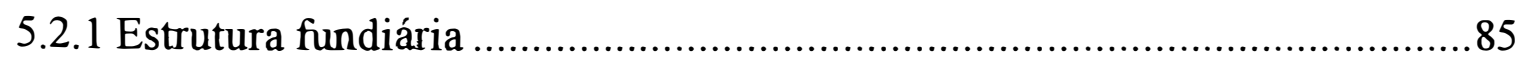

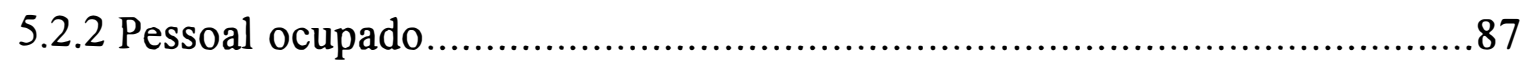

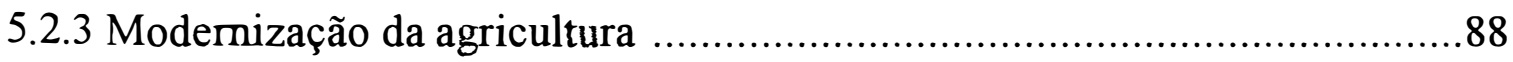

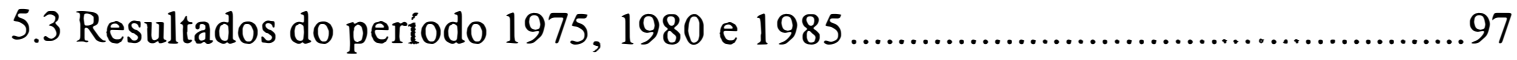

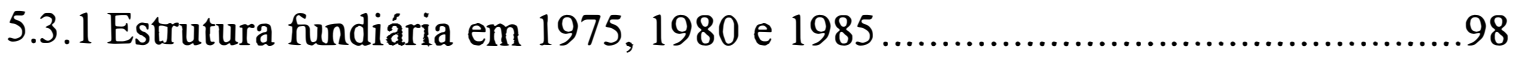

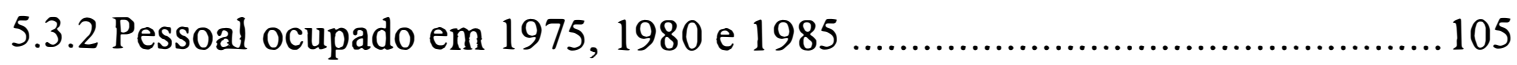

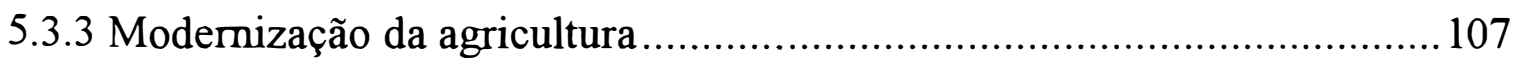

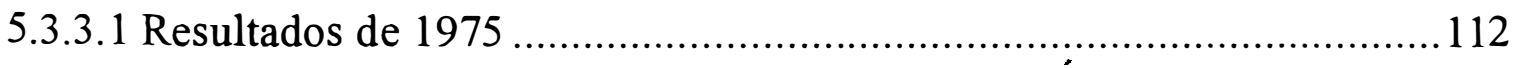

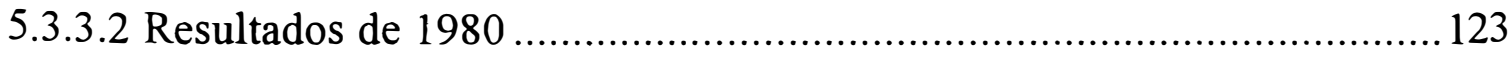

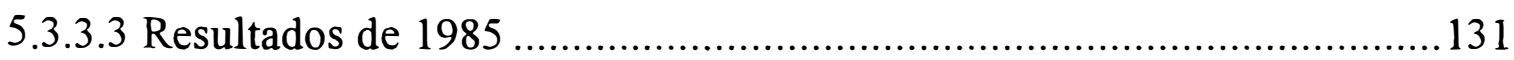

5.4 Resumo dos resultados de 1920 a 1985 ................................................. 140

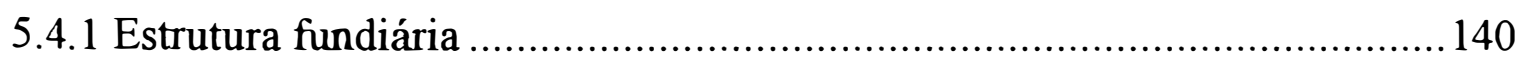

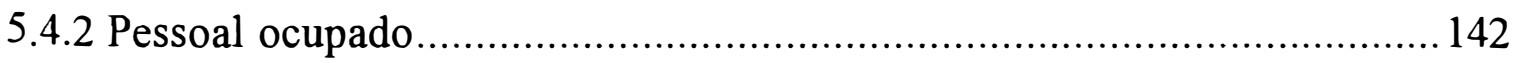

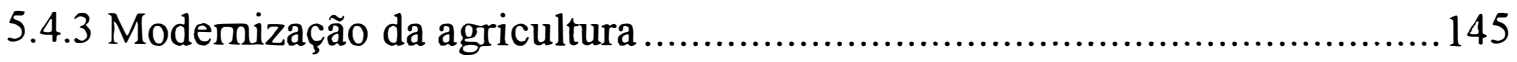

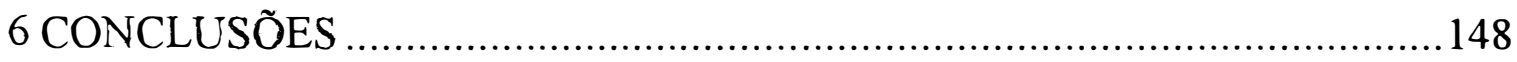

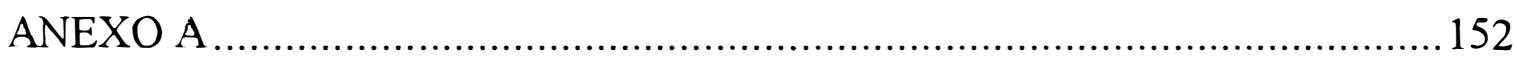

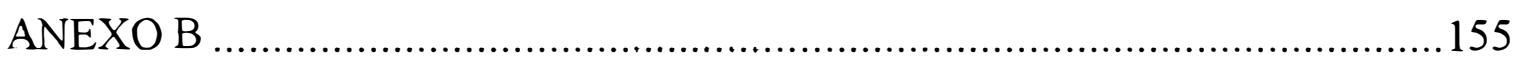

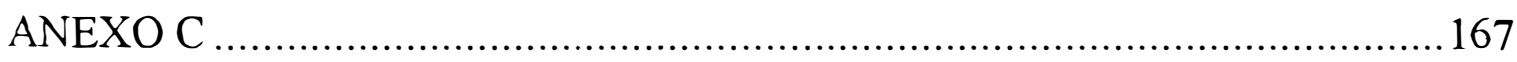

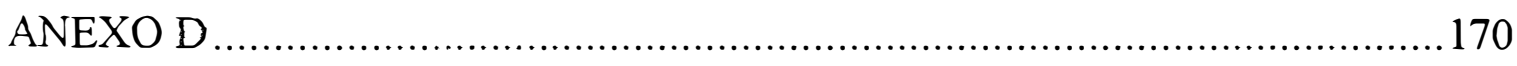

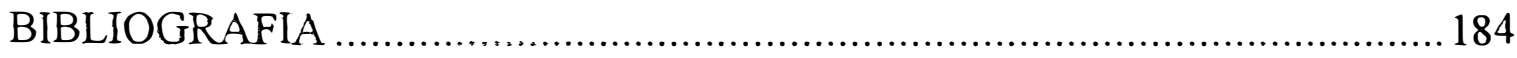




\section{LISTA DE MAPAS}

Página

1 Localização geográfica do Estado de Santa Catarina .28

2 Processo de ocupação do Estado de Santa Catarina. 31

3 Complexos industriais do Estado de Santa Catarina 41

4 Distribuição dos fatores nos municípios do Estado de

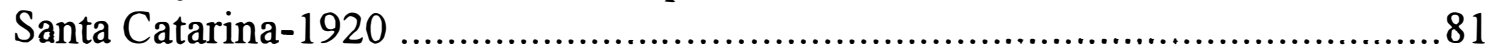

5 Distribuição dos fatores nos municípios do Estado de Santa Catarina-1950

6 Distribuição dos fatores nos municípios do Estado de Santa Catarina-1975 118

7 Distribuição dos fatores nos municípios do Estado de Santa Catarina-1980 128

8 Distribuição dos fatores nos municípios do Estado de Santa Catarina-1985 136 


\section{LISTA DE TABELAS}

Página

1 População total, urbana e rural do Estado de Santa Catarina-1920, 1950, 1970,1980 e 1991

2 Percentual de municípios de acordo com o valor do índice de Gini e percentual de municípios com estabelecimentos de área média superior a 50 hectares, MRHs do Estado de Santa Catarina, 1920

3 Pessoal ocupado na agricultura, criação, caça e pesca em equivalenteshomem e percentual de mão-de-obra masculina e feminina, maiores de 21 anos e menores de 21 anos, MRHs do Estado de Santa Catarina, 1920 .....75

4 Raízes características da matriz de correlações simples $(13 \times 13)$ para ra os municípios do Estado de Santa Catarina, 1920

5 Coefíciente de correlação, comunalidade de cada variável e variância explicada pelos fatores após rotação pelo método VARIMAX, municípios do Estado de Santa Catarina, 1920.

6 Percentual de municípios que apresentaram valores positivos (altos e médios) para os fatores, segundo as MRHs do Estado de Santa Catarina, 1920

7 Percentual de municípios de acordo com o valor do índice de Gini, área média superior a 50 hectares e percentual de estabelecimentos com área menor do que 10 hectares, MRHs do Estado de Santa Catarina, 1950

8 Composição percentual do pessoal ocupado na agricultura, MRHs do Estado de Santa Catarina, 1950 .88

9 Raízes características da matriz de correlações simples (19 x 19) para os municípios do Estado de Santa Catarina, 1950 90 
Página

10 Coeficiente de correlação, comunalidade de cada variável e variância explicada pelos fatores após rotação pelo método VARIMAX, municípios do Estado de Santa Catarina, 1950.

11 Percentual de municípios que apresentaram valores positivos (altos e médios) para os fatores, segundo as MRHs do Estado de Santa Catarina, 1950

12 Percentual de municípios de acordo com o valor do índice de Gini, MRHs do Estado de Santa Catarina, 1975, 1980 e 1985

13 Percentual de municípios com estabelecimentos de área média superior a 50 hectares, MRHs do Estado de Santa Catarina, 1975, 1980 e 1985

14 Percentual de estabelecimentos com área inferior a 10 hectares, MRHs do Estado de Santa Catarina, 1975, 1980 e 1985

15 Percentual de municípios que apresentaram aumento do número de estabelecimentos, aumento da área média e aumento do valor do índice de Gini no período 1975-1985, MRHs do Estado de Santa Catarina 104

16 Composição percentual do pessoal ocupado na agricultura, MRHs do Estado de Santa Catarina, período 1975-1985

17 Raízes características da matriz de correlações simples $(22 \times 22)$ para ra os municípios do Estado de Santa Catarina, 1975

18 Coeficiente de correlação, comunalidade de cada variável e variância explicada pelos fatores após rotação pelo método VARIMAX, municípios do Estado de Santa Catarina, 1975.

19 Percentual de municípios que apresentaram valores positivos (altos e médios) para os fatores, segundo as MRHs do Estado de Santa Catarina, 1975 
Página

20 Raízes características da matriz de correlações simples $(22 \times 22)$ para ra os municípios do Estado de Santa Catarina, 1980

21 Coefíciente de correlação, comunalidade de cada variável e variância explicada pelos fatores após rotação pelo método VARIMAX, municípios do Estado de Santa Catarina, 1980.

22 Percentual de municípios que apresentaram valores positivos (altos e médios) para os fatores, segundo as MRHs do Estado de Santa Catarina, 1980

23 Raízes características da matriz de correlações simples $(22 \times 22)$ para ra os municípios do Estado de Santa Catarina, 1985

24 Coefíciente de correlação, comunalidade de cada variável e variância explicada pelos fatores após rotação pelo método VARIMAX, municípios do Estado de Santa Catarina, 1985

25 Percentual de municípios que apresentaram valores positivos (altos e médios) para os fatores, segundo as MRHs do Estado de Santa Catarina, 1985

26 Número, área total, área média, índice de Gini e percentual da área total correspondente aos 50\% menores e 5\% maiores estabelecimentos agropecuários do Estado de Santa Catarina, 1920, 1950, 1975, 1980 e 1985

27 Pessoal ocupado na agricultura em equivalentes-homem e composição percentual da mão-de-obra rural no Estado de Santa Catarina, $1920,1950,1975,1980$ e 1985 


\title{
TRANSFORMAÇÕES DA AGRICULTURA NO
}

\author{
ESTADO DE SANTA CATARINA, 1920-1985
}

\author{
Autora: EVELISE NUNES DO ESPÍRITO SANTO \\ Orientadora: Profa. ZILDA PAES DE BARROS MATTOS
}

\section{RESUMO}

O objetivo deste estudo foi verificar as transformações ocorridas na agricultura dos municípios do Estado de Santa Catarina, tendo como pressuposto que as mesmas já vinham ocorrendo em períodos anteriores ao das intensas políticas de modernização adotadas na década de 1960. A metodologia utilizada foi a análise fatorial ponderada, o cálculo das medidas do grau de concentração da posse da terra e a análise do pessoal ocupado na agricultura, em cinco cortes temporais: 1920, 1950, 1975, 1980 e 1985.

Os resultados mostraram que apesar de terem ocorrido alterações significativas no número de municípios, número e área total dos estabelecimentos agropecuários, o valor do índice de Gini predominou, na maior parte dos municípios, de 1920 a 1985 na faixa de média e forte concentração fundiária, com o aumento da concentração no período mais recente de 1975 a 1985. A forma de ocupação do Estado parece ter sido o principal fator a contribuir para uma distribuição menos desigual da posse da terra, quando comparado a outras regiões do Brasil.

O pessoal ocupado na agricultura foi crescente de 1920 a 1985, estando no início do século principalmente nas regiões litorâneas e em 1985 na microrregião 
homogênea Colonial do Oeste Catarinense. A mão-de-obra familiar foi, sem dúvida, a categoria mais importante da força de trabalho desde 1950 em todo o Estado, embora tenha sofrido um leve declínio durante o período analisado.

A intensidade de exploração da terra, quase sempre associada ao uso da força animal, o uso de mão-de-obra familiar e pastagens plantadas, foi o principal fator explicativo das transformações ocorridas na agricultura catarinense, divergindo dos resultados obtidos para outras regiões brasileiras.

A modernização da agricultura foi parcial, limitando-se a setores ligados às agroindústrias como avicultura, suinocultura, cana-de-açúcar e fumo. Entretanto, alguns desses setores (avicultura e suinocultura principalmente) foram afetados pelas políticas econômicas adotadas desde o início do Plano Real, resultando na migração de milhares de pequenos produtores, especialmente do Oeste Catarinense. Portanto, sugere-se que futuros estudos devam considerar e avaliar os reflexos das políticas econômicas sobre os complexos agroindustriais assim como as relações destes com os produtores, com vistas a um desenvolvimento sustentável. 


\title{
TRANSFORMATIONS OF THE AGRICULTURE \\ IN THE STATE OF SANTA CATARINA, 1920-1985
}

\author{
Author: EVELISE NUNES DO ESPÍRITO SANTO \\ Adviser: Profa. ZILDA PAES DE BARROS MATTOS
}

\section{SUMMARY}

The objective of this study was to verify the transformations occurred in the agriculture of the municipalities of the state of Santa Catarina, assuming that they were already in course in periods before that of the more intense modemization policies adopted of the sixties. The methodologies utilized were the weighted factorial analysis, the calculation of indicators of land tenure concentration and the analysis of rural labor force in five cross sections: 1920, 1950, 1975 e 1985.

The results showed that in spite of the significant changes that occurred in the number of municipalities and in the number and total area of farms, the Gini values prevailing in the majority of the municipalities, from 1920 to 1985, indicated that land concentration ranged from medium to high, with increase in the concentration in the most recent period, from 1975 to 1985 . The way the State was occupied seems to be the main factor contributing to a less unequal land tenure distribution when compared to other regions in Brazil.

Rural labor force increased from 1920 to 1985, being mainly in the Coastal regions in the beginning of the century and in 1985 in the homogeneous microregion Colonial do Oeste Catarinense. Family labor was, undoubtedly, the 
most important labor category since 1950 , in the whole State, although it has slightly declined during the analysed period.

The intensity of land use, almost always related to animal drafting, the use of family labor and cultivated pastures, was the main factor explaining the transformations occurred in the catarinense agriculture, as opposed to results obtained for other Brazilian regions.

The agriculture modernization was partial, restricted to sectors related to agribusiness like poultry, swine, sugar cane and tobacco. However, some of these sectors (poultry and swine mainly) were affected by economic policies adopted since the beginning of the so-called Plano Real, resulting in the migration of thousands of small farmers, specially from the West. Therefore, it is suggested that future studies should consider and evaluate the effects of economic policies on agribusiness complexes as well as the relations of the latter with farmers, in search for a sustained development. 


\section{INTRODUÇÃO}

\subsection{O problema e a sua justificativa}

A modernização ocorrida na agricultura asiática no final dos anos 60 e início dos anos 70, envolvendo principalmente a Índia e o Paquistão, foi marcante na história da agricultura mundial (vide Evenson, 1983; Brown, 1983 e Stern, 1994). Esta modernização foi denominada de revolução verde e baseou-se na adoção e difusão de sementes de alta produtividade e de insumos como fertilizantes, irrigação e máquinas que produziram um rápido aumento na produtividade de certas culturas como a do trigo e do arroz, com vistas a tornar estes Países auto-suficientes em alimentos.

No Brasil, entretanto, no mesmo período, segundo Hoffmann \& Kageyama (1985), o processo de modernização da agricultura não ocorreu sob o mesmo tipo de impacto da revolução verde. Possivelmente porque o processo de industrialização e as bases da agricultura brasileira já estavam mais avançados do que naqueles Países, juntamente com a pesquisa de novas variedades, especialmente de híbridos do milho, assim como os objetivos deste processo que no Brasil visava a exploração do excedente agrícola exportável para financiar o 
setor industrial .

O processo de modernização da agricultura brasileira, em geral definido como o uso de tecnologias, ou inovações, que alteram a estrutura técnica produtiva e também as relações sociais de produção, tomou maior impulso na primeira metade da década de 60 . A concessão de crédito rural relacionada à posse da terra foi a principal política utilizada com o objetivo de modernizar a agricultura. As políticas modemizantes adotadas conduziram, basicamente, ao aumento da produtividade agrícola e a um maior assalariamento da mão-de-obra rural, levando também à associação entre a concentração fundiária e a modemização, tendo como principais conseqüências negativas o aumento da desigualdade na distribuição da renda e o êxodo rural.

Nas últimas décadas, devido a sua importância, o estudo do processo de modemização da agricultura e as suas conseqüências sobre os níveis de produtividade, distribuição de retornos, nível de emprego e mesmo sobre os recursos naturais, tem sido objeto de diversas análises (vide Paiva, 1975; Vergara Filho, 1993; Silva, 1993 e Kageyama, 1993). Verificando-se, assim, inúmeras questões e estudos envolvendo a modernização da agricultura brasileira, o que torna o conhecimento de todo este processo e de suas conseqüências sobre o desenvolvimento rural essencial para aumentar a eficácia de políticas voltadas ao setor, principalmente a partir da abertura política e da tendência de descentralização do Estado.

Entretanto, apesar dos diversos estudos para o caso brasileiro, são poucos os que avaliam ou descrevem o processo de modernização da agricultura no Estado de Santa Catarina e em suas microrregiões. Este Estado onde predominam as pequenas propriedades, e que em termos de extensão territorial é um dos menores do País, apresenta relativa importância para a economia nacional devido aos complexos agroindustriais de fumo, suínos e aves ali instalados e que foram 
favorecidos pelos amplos incentivos governamentais fornecidos, principalmente na década de 70 , os quais estimulavam a integração vertical com destaque aos setores de avicultura e suinocultura.

Atualmente, tem sido atribuído às agroindústrias o papel de agente de mudança tecnológica, pois acredita-se que impõem aos produtores associados à elas um determinado padrão de qualidade que evidencia a necessidade do uso de tecnologias modernas. A acirrada competição existente entre as empresas do complexo agroindustrial do Estado teria, desta forma, contribuido para o desenvolvimento regional. Autores como Sorj et al. (1982), Paulilo (1987) e Marques (1991), por exemplo, avaliaram o sistema como trazendo vantagens aos produtores, na forma de menores oscilações de preços e melhor assistência técnica, sendo uma forma de fixar o homem ao campo, pois pode proporcionar uma renda mais uniforme.

A modernização da agricultura relacionada às agroindústrias também foi colocada em um estudo específico para o Estado de Santa Catarina, realizado por Zanchet (1990) para o período 1970-1980. Este estudo concluiu ter havido uma modernização articulada ao complexo agroindustrial, sendo que a mesma não teria ocorrido de uma forma homogênea nas microrregiões. Assim, teríamos o setor agroindustrial como tendo modernizado e levado a agricultura catarinense a apresentar resultados positivos nos segmentos relacionados a ele, mantendo a estrutura de pequena propriedade.

Entretanto, dentro dos padrões estabelecidos para o País, o Estado foi um dos que apresentaram maior grau de atraso com relação à modernização da agricultura (Hoffmann \& Kageyama, 1985) relacionado principalmente com a alta participação da mão-de-obra familiar na agricultura. A alta participação da mãode-obra familiar teria levado também, segundo Hoffmann (1992), várias microrregiões a apresentar uma relação capital/trabalho bastante reduzida. Porém, 
estes estudos se referem apenas ao período considerado na literatura como sendo de mais intensa modemização no País, as décadas de 1970 e 1980, não tendo sido encontrados estudos específicos anteriores a este período que pudessem conduzir a maiores conclusões sobre a modernização da agricultura catarinense e a possibilidade de este processo já vir ocorrendo através do tempo.

Assim, a presente pesquisa buscou verificar, em um período de tempo mais amplo, as transformações ocorridas na agricultura catarinense utilizando os municípios como unidades de análise em cinco cortes temporais: 1920, 1950, 1975, 1980 e 1985. Para tal, supôs-se a possibilidade de que, dentro do contexto sócio-político e econômico do País, já vinha ocorrendo desde o primeiro período considerado na pesquisa, a década de 1920, mudanças no setor agropecuário do Estado de Santa Catarina, as quais poderiam ser consideradas como tentativas de modernização de acordo com as características específicas do Estado.

\subsection{Objetivos}

\subsubsection{Objetivo geral}

O objetivo geral do estudo foi verificar as transformações ocorridas na agricultura do Estado de Santa Catarina envolvendo a modernização, o pessoal ocupado e a sua estrutura fundiária, tendo como base as teorias e modelos de desenvolvimento agrícola e o contexto sócio-político-econômico no qual ocorreu o processo de modernização da agricultura brasileira. No estudo foram analisados os municípios catarinenses em cinco corte temporais: 1920, 1950, 1975, 1980 e 1985. 


\subsubsection{Objetivos específicos}

a) Verificar se ocorreu uma modemização, qual o seu grau efetivo, e as variáveis relacionadas a este processo nos municípios das microrregiões homogêneas do Estado de Santa Catarina, nos anos de 1920, 1950, 1975, 1980 e 1985;

b) Verificar a evolução da estrutura fundiária nos municípios das microrregiões homogêneas do Estado de Santa Catarina, nos anos de 1920, 1950, 1975, 1980 e 1985;

c) Identificar as mudanças ocorridas no mercado de trabalho rural dos municípios das microrregiões homogêneas de Santa Catarina, nọs anos de 1920, 1950, 1975,1980 e 1985.

\subsection{Organização do estudo}

O estudo está organizado em capítulos. No capítulo 2 consta a literatura acerca das políticas, teorias e modelos que formaram a base do processo de modernização da agricultura brasileira e os efeitos desta modernização sobre o nível de renda, o mercado de trabalho rural, a distribuição de renda e a posse da terra. O capítulo 3 apresenta o Estado de Santa Catarina, a sua divisão territorial, população, a sua importância econômica para o Brasil e o processo de ocupação de suas terras, colonização, com ênfase sobre a modernização da sua agricultura.

No capítulo 4 é apresentado o método de análise utilizado na condução do estudo e algumas considerações sobre os dados utilizados. No capítulo 5 são apresentados os resultados obtidos no estudo e a sua discussão e no capítulo 6 estão as conclusões resultantes da análise realizada. 


\section{MODERNIZAÇÃO DA AGRICULTURA}

Neste capítulo estão as principais teorias e modelos que forneceram a base para a modemização do setor agrícola brasileiro e algumas considerações acerca das conseqüências deste processo sobre o nível de renda, o mercado de trabalho rural, a distribuição de renda e a posse da terra.

\subsection{As bases do processo: teorias e modelos}

Na literatura existente consta uma série de modelos que explicam como ocorre, ou em que se baseia, o desenvolvimento da economia de uma forma global, incluindo a importância do setor agrícola. Este assunto é tratado por autores como Stern (1994 e 1991); Araújo (1975); Johnston \& Mellor (1961), entre outros. São vários também os modelos que formaram a base da modemização do setor agrícola, sendo que, os conceitos e idéias que direcionaram a teoria da modernização tiveram papel importante no crescimento da agricultura dos Países mais desenvolvidos tendo influenciado, também, a agricultura brasileira. 
$\mathrm{O}$ crescimento da agricultura e os baixos índices de produtividade registrados pelo setor no final dos anos 50 e início dos anos 60, se constituiu em alvo de opiniões controvertidas que foram amplamente discutidas e divulgadas pela literatura. A divergência de opiniões deu origem a diversas correntes que buscavam uma explicação e solução para os problemas da agricultura, as quais podem ser agrupadas em apenas duas: a que considerava as questões relacionadas a estrutura agrária, isto é, se a mesma deveria ocorrer e em que condições, e a que tinha enfoque na estrutura de produção (modernização do setor). Pelas suas características, esta última foi a que prevaleceu, principalmente a partir de 1964, onde foi adotado um conjunto de políticas e ações direcionadas ao que viria a ser denominado de "revolução tecnológica". Isto porque a agricultura não podia mais crescer apenas em extensão; eram necessários aumentos de produtividade que deveriam ser obtidos em um curto espaço de tempo.

Cline (1970) aponta duas diferenças primárias entre as políticas que partem da redistribuição de terras e as convencionais ( referentes a preços, subsídios a insumos modernos, extensão, crédito rural, armazenamento, transporte, sem que a redistribuição de terras seja o ponto de partida) que marcam os estudos neste aspecto: "A redistribuição de terras pode aumentar a produção melhorando a eficiência da estrutura agrícola, enquanto as políticas convencionais aumentam a produção induzindo a utilização de mais insumos numa ineficiente base estrutural. E, a redistribuição de terras opera simultaneamente na procura de atingir duas metas, eqüidade na distribuição de renda e aumento no nível de produção, enquanto as políticas convencionais tem por meta o aumento da produção, só incidentalmente atendendo eqüidade na distribuição de renda."

Devido a abrangente literatura existente acerca do assunto foram colocados neste capítulo, de forma sucinta, os principais aspectos do referencial teórico que serviu de fundamento para estas correntes, especialmente com relação à trajetória 
e às variáveis que caracterizaram a modernização da agricultura brasileira. Inicialmente são abordados alguns estudos cujo enfoque é a estrutura agrária, seguidos dos modelos neoclássicos.

A princípio, destaca-se a tese estruturalista cuja base se encontra no

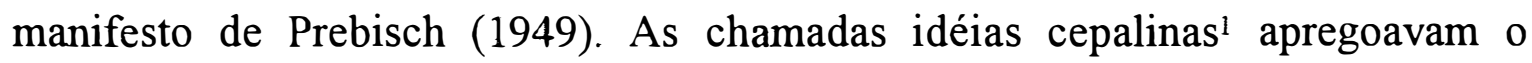
desenvolvimento via mercado interno através da industrialização: "...ela (a industrialização), não é um fim em si mesma, mas o único meio de que se dispõe para captar uma parte do fruto do progresso técnico e elevar progressivamente o nível de vida das massas" (Prebisch, 1949, p.48), isto porque, segundo ele, a demanda mundial por produtos agrícolas era inelástica com relação a preços e a renda, impossibilitando o desenvolvimento via exportação de produtos primários. Portanto, o desenvolvimento só poderia ser alcançado via industrialização.

Esta industrialização ocorreu no Brasil com a adoção do modelo de substituição de importações. Este modelo protegia a indústria nacional através da criação de oportunidades de investimentos geradas pela não importação de produtos de consumo. Segundo esta tese, a industrialização seria acompanhada de aumentos de demanda de alimentos e da transferência de mão-de-obra do setor rural para o urbano. Por sua vez, o êxodo rural aumentaria o salário rural, favorecendo a modernização da agricultura.

A princípio, os estruturalistas baseados nos primeiros estudos da CEPAL defendiam a posição de que a estrutura fundiária não teria necessidade de transformações para que pudesse ocorrer o desenvolvimento através da industrialização, pois acreditavam que a concentração fundiária não tinha sido um obstáculo ao crescimento da produção agrícola nas terras da Argentina e do Estado de São Paulo no Brasil.

\footnotetext{
${ }^{1}$ Cepalinas, termo relacionado a CEPAL (COMISSÃO ECONÔMICA PARA A AMÉRICA LATINA)
} 
Para o caso brasileiro, as idéias iniciais da CEPAL foram contestadas por Furtado (1972, p.112): "(...)essa análise passava por alto o fato de que, existindo uma fronteira móvel e uma oferta elástica de mão-de-obra originária de fora da região, tratava-se menos de desenvolvimento que de ocupação econômica de um território". Para Furtado era a estrutura agrária concentrada que impedia alterações na oferta de mão-de-obra rural, que se mantinha com baixos salários e elástica. Assim, a modernização ocorreria a partir de mudanças na estrutura agrária e na distribuição da renda; como conseqüência, a corrente estruturalista propôs mudanças na estrutura agrária para que o desenvolvimento pudesse ocorrer.

Por sua vez, Guimarães (1977) coloca a estrutura fundiária concentrada e com características feudais como sendo o principal fator de atraso no desenvolvimento da agricultura no Brasil. Esta estrutura agrária concentrada teria sua origem no período de colonização do País, onde houve a sua divisão em lotes de terras, as chamadas donatarias e sesmarias. Este fato criou uma relação feudal e concentrada de posse e uso da terra levando também à concentração de renda. Este processo veio acompanhado inicialmente da mão-de-obra escrava, posteriormente substituída pela mão-de-obra imigrante. As relações de produção, principalmente o latifúndio (ou monopólio) feudo-colonial, dificultavam 0 desenvolvimento capitalista, situação esta que poderia ser modificada através de uma reforma agrária.

Um dos primeiros oponentes `a tese feudal foi Prado Júnior (1979) cujos argumentos estavam baseados principalmente no fato de que, do processo de colonização originaram-se os trabalhadores sem-terra e os baixos salários rurais, 0 que resultou em baixos níveis de vida, impedindo, assim, o desenvolvimento da agricultura. Basicamente este enfoque enfatiza que a mão-de-obra no País, inicialmente de origem escrava, foi substituída pelo trabalhador assalariado que 
almeja a melhoria de salário e não a exploração e posse da terra como os agricultores europeus. Não fazendo sentido, muitas vezes, uma reforma agrária que viria a dividir e destruir as grandes propriedades, ao invés de socializá-las, num contexto onde as reivindicações são melhores empregos e salários. As mudanças na estrutura fundiária, segundo esta tese, devem necessariamente ser acompanhadas de melhorias na qualidade de vida e renda dos trabalhadores.

O dualismo existente na agricultura brasileira foi caracterizado pela coexistência de relações de produção modernas com as tradicionais, sendo avaliado por Rangel (1962), que foi um dos principais representantes desta linha. A corrente dualista priorizava questões tais como: solucionar a escassez de determinados produtos agrícolas, o mercado de trabalho rural e a transformação dos latifúndios feudais em propriedades modernas. Estẹs fatores se constituíam em barreiras que impediam o desenvolvimento capitalista, os quais eram mais rápidos e viáveis de serem removidos do que implementar uma reforma agrária.

A tese dualista tinha como proposta solucionar os problemas rurais a partir da doação de lotes de terra aos trabalhadores rurais, que além de se assalariarem ao latifúndio próximo, produziriam para o auto-consumo complementando suas rendas, o que garantiria o mercado de mão-de-obra rural. Com relação ao mercado de produtos agrícolas, o desenvolvimento de políticas de preços mínimos, armazenagem e crédito foram as medidas propostas. Já as modificações com relação ao mercado de terras, que levassem à redução do seu preço, visavam transformar a terra em uma unidade produtiva tornando, assim, o latifúndio feudal em capitalista.

O mesmo autor em outro estudo de 1979, novamente coloca a sua posição, perante às condições de urbanização existentes, contra um determinado tipo de reforma agrária que viria a multiplicar o número de pequenas explorações 
familiares orientadas para a policultura e com o objetivo primordial de autoconsumo com a retenção de mão-de-obra no campo.

Entretanto, as colocações referentes à mudanças ou não na estrutura agrária foram pouco enfatizadas pela chamada corrente neoclássica, que fundamentou as políticas e o processo de modernização da agricultura brasileira, segundo o qual a agricultura não poderia apenas crescer em extensão; deveriam haver aumentos de produtividade no curto prazo. Dos modelos pertencentes à corrente neoclássica, relacionando agricultura e desenvolvimento, destacam-se os trabalhos pioneiros de Schultz (1953 e 1964), seguidos do modelo de difusão, e dos modelos de Hayami \& Ruttan $(1971)^{2}$, De Janvry (1978) e Paiva (1975) que melhor explicam o caso brasileiro.

O modelo de impacto urbano industrial, ou modelo de localização, desenvolvido por Schultz (1953), enfatiza como hipótese o melhor funcionamento de mercados agrícolas em função de sua localização próxima aos centros industriais dinâmicos. Schultz formulou as suas implicações para o desenvolvimento agrícola a partir do estudo pioneiro de Johann Heinrich Von Thünen (1783/1850), que buscava explicar como a urbanização determina a localização da produção agrícola e influencia as técnicas e intensidades de cultivo.

O modelo de impacto urbano-industrial tem como princípio os pólos industriais, que trariam como conseqüências o aumento de demanda de mão-deobra, insumos e produtos originários do setor agrícola levando a um aumento da tecnificação do setor. Este modelo foi utilizado como explicação para o desenvolvimento da atividade agrícola do Estado de São Paulo e de outras regiões de mais recente desenvolvimento. Apesar de ter sido validado para várias situações foi considerado limitado para os Países menos desenvolvidos, onde

\footnotetext{
2 Constantes de Hayami e Ruttan (1988)
} 
não existem as tecnologias necessárias ao crescimento da agricultura e tem-se como prioridade o crescimento dos setores não-agrícolas.

A disseminação de técnicas de exploração, variedades de culturas e de raças de animais, formaram a base do chamado modelo de difusão que influenciou grande parte do trabalho de pesquisa e extensão em uso na atualidade. O elemento-chave deste modelo é a pressuposição de que já existiam conhecimentos técnicos suficientes para levar aos aumentos de produtividade desejados, sendo o problema a sua difusão. Na década de 50, partindo destas colocações, foram estabelecidos programas de assistência técnica, que entretanto não foram bem sucedidos em levar à rápida modernização das fazendas tradicionais ou ao rápido crescimento da produção agrícola. O trabalho de Griliches (1957) sobre a produção e propagação do milho híbrido nos Estados Unidos é um exemplo deste modelo.

Através da crítica com relação à possibilidade de transferir um pacote tecnológico agrícola de Países de alta produtividade para os de baixa produtividade, surgiu o modelo de insumos modernos desenvolvido por Schultz (1964). Em seu modelo, Schultz considera os agricultores tradicionais de Países pobres como sendo eficientes na alocação de seus recursos, porém com oportunidades técnicas e econômicas limitadas; por isto, permanecem pobres. A mudança tecnológica foi vista por Schultz não como um conceito analítico para explicar o crescimento econômico, pois é uma denominação para um conjunto de resíduos não explicados: "(...) isso não quer dizer que o termo "mudança tecnológica" não possa ser um artifício útil para certas finalidades expositórias. Mas não é um conceito analítico para explicação do crescimento econômico. Usálo com essa finalidade é uma confissão de ignorância, porque é apenas um nome para um conjunto de resíduos não explicados" (Schultz, 1964, p. 141).

$\mathrm{Na}$ opinião de Schultz, o que desenvolve o setor agrícola são os 
investimentos especificamente em educação e pesquisa que tornam os insumos modernos disponíveis aos agricultores. Este modelo foi considerado incompleto como teoria de crescimento agrícola, pois não esclarece adequadamente 0 processo pelo qual a ação conjunta, desde a comunidade local até ao governo central, pode ser organizada para a oferta de bens públicos.

Foi a partir de Hayami \& Ruttan (1971) que o processo de mudança técnica se tornou endógeno ao sistema econômico, através do modelo de inovações induzidas, que considera o desenvolvimento de tecnologias poupadoras de fatores escassos. O modelo propõe que, para alcançar um crescimento rápido na produção e produtividade agrícola, é necessário que o País faça uma escolha eficiente de acordo com a dotação relativa de seus recursos, indicando os mecanismos de inovação induzida nos setores público e privado, dando ao setor público papel de destaque na geração de tecnologias.

No setor público, a inovação técnica é induzida pela dotação de fatores, expressa pelos preços de mercado e que conduz os agricultores a pressionarem por tecnologias. No setor privado, as firmas competitivas são racionais quando alocam os seus recursos financeiros no desenvolvimento de tecnologias que facilitam a substituição dos fatores mais caros pelos mais baratos. Neste modelo os insumos primários são os fatores terra e trabalho, o capital é secundário, porém o modelo pode ser aplicado se qualquer outro recurso tiver oferta inelástica.

De acordo com Santos (1986), o modelo de Hayami \& Ruttan enfatiza a escassez relativa dos fatores a nível agregado indicando a direção da inovação, mas a distorção na alocação dos fatores entre os produtores não é considerada. É o caso, por exemplo, de haver um grande número de pequenos agricultores com escassez de terra, mas se o mesmo não ocorre para a economia global, a inovação não se direcionará no sentido de poupar terra; enfatiza também a necessidade de existir um sistema de comunicação entre os produtores, instituições públicas de 
pesquisa, empresas privadas que ofertam insumos e os mercados de fatores e produtos.

Na mesma linha de análise de Hayami \& Ruttan está o modelo de pressão de grupos sociais de De Janvry (1978), que considera a geração de inovações técnicas e institucionais de um bem público. A oferta e demanda por bens públicos está localizada, segundo este modelo, na matriz de retornos esperados e condicionada pelas estruturas sócio-econômica e político-burocrática e as instituições produtoras de inovações. Fazem parte da estrutura sócio-econômica a posse da terra, o nível tecnológico, o preço dos fatores e produtos, o acesso ao crédito, a informação e a educação.

$\mathrm{Na}$ estrutura político-burocrática deste modelo são importantes o sistema de pressão social, o sistema eleitoral, o sistema de ganhos burocráticos e o sistema legislativo que transforma os compromissos em específicas apropriações de orçamento e leis. O poder de pressão dos diferentes grupos sobre a estrutura político-burocrática determina se a demanda latente é transformada em demanda real, que se torna oferta real de inovações pelas instituições produtoras. Nestas instituições o armazenamento do conhecimento científico, e a alocação do capital físico e humano para a pesquisa básica, são os determinantes da posição da curva de possibilidades de inovações.

Para finalizar os modelos que teriam influenciado de alguma forma às políticas de modernização da agricultura brasileira, temos o mecanismo de autocontrole de Paiva (1975) que considera o dualismo tecnológico existente na agricultura como sendo uma característica normal nos Países em desenvolvimento. Neste modelo, uma economia regida pelas leis de mercado, a adoção e difusão de tecnologias levariam a aumentos de produção e de produtividade com uma conseqüente queda de preços dos produtos e dos fatores tradicionais de produção (terra e mão-de-obra). Este mecanismo faz com que 
diminua a vantagem econômica do uso da tecnologia moderna sobre a tradicional reduzindo o interesse de novos agricultores em se modernizar.

O chamado grau máximo de modernização influencia a modernização da agricultura, que fica então dependente da expansão do setor não-agrícola, através da capacidade deste em expandir o consumo de produtos agrícolas e absorver a mão-de-obra expulsa do setor agrícola. As técnicas demandantes em capital fixo estariam sujeitas a este mecanismo, enquanto técnicas que não exigem despesas adicionais de produção são as únicas não sujeitas ao mesmo. Isto implicaria que os Países em desenvolvimento não podem contar com uma modernização generalizada. Forçar a mesma só levaria a maiores prejuízos e ao êxodo.

Assim, a agricultura passaria a exercer um papel secundário na criação de novos fluxos de renda e no desenvolvimento sendo, portanto, considerados de fundamental importância os serviços de pesquisa e assistência técnica, com vistas ao desenvolvimento de técnicas que proporcionem melhores retornos e o atendimento daqueles agricultores que não podem se modernizar.

\subsection{Conseqüências gerais da modernização}

Os efeitos do desenvolvimento capitalista sobre os níveis de renda, de uma forma geral, vêm sendo estudados por diversos autores, havendo também, dois gnupos formadores de hipóteses com relação à questão. O primeiro grupo, e o mais difundido, é o liderado pelas idéias de Kuznets (1955), para quem nos estágios iniciais e intermediários do desenvolvimento de um País o crescimento vem acompanhado do aumento da desigualdade distributiva. O segundo grupo defende as idéias de que a distribuição de renda não só é conseqüência do nível de desenvolvimento, mas também das políticas e estratégias adotadas pelo País. Neste último grupo, onde estão Fields (1980) e Cline (1975), são defendidas as 
idéias de que a distribuição de renda não necessariamente deve piorar antes de se tornar mais igualitária; o crescimento não é prejudicial às classes populares sendo, portanto, contra a suposição de que para haver crescimento rápido pode haver mais desigualdade.

No Brasil, uma forma geral, nos períodos iniciais do desenvolvimento se confirmaram as hipóteses de Kuznets, pois no período denominado de "milagre econômico brasileiro" (1968-1973) a economia cresceu aceleradamente, sendo este crescimento acompanhado do aumento da desigualdade na distribuição de renda. Especificamente para o setor agropecuário as políticas voltadas ao desenvolvimento, tais como a modernização da agricultura, também conduziram ao aumento da desigualdade na distribuição da renda. Estas hipóteses se confirmam também na atualidade, onde o Brasil se encontra em uma fase onde é considerado um País em desenvolvimento, e a desigualdade ainda permanece.

Entre os anos de 1970 e 1980, o processo de concentração da renda no País, entre famílias e pessoas, foi mais intenso no setor agropecuário do que nos setores urbano-industrial, inversamente ao ocorrido na década de 1960-1970, verificando-se também, que o elemento fundamental da desigualdade na distribuição da renda, entre as regiões de agricultura menos modemizada e mais modernizada era a própria modernização. Hoffmann \& Kageyama (1986, p.37), por exemplo, evidenciaram que: "As características da modernização a que esteve submetida a agricultura na década de 70 , especialmente as que dependem da escala de produção, e as políticas associadas, tais como a política fundiária e a de crédito rural, são em grande parte responsáveis pelas desigualdades da distribuição de renda no setor agropecuário. A modernização tendeu a favorecer o aumento da participação relativa das camadas mais ricâs na apropriação da renda total, a despeito de ter contribuído para a melhoria geral dos níveis de renda e para a redução da pobreza absoluta". 
No período 1975-1980, as associações neste sentido relacionam positivamente o grau de modernização com o nível de renda "per capita" e a desigualdade na distribuição de renda e negativamente com os níveis de pobreza absoluta no meio rural, o que pode ser constatado em estudos para as diversas unidades da federação (Hoffmann \& Kageyama, 1985) e para o Brasil (Hoffmann et al., 1985). Pesquisas baseadas em dados de microrregiões homogêneas também conduziram a resultados semelhantes na maior parte dos casos.

Estudos como o de Leone (1988), para o Estado da Bahia, Del Grossi (1989), para o Estado do Paraná e Hoffmann \& Kassouf (1989) para 158 microrregiões de oito Estados brasileiros, no período 1970-1980, igualmente relacionam a modernização da agricultura com maiores níveis de renda e desigualdade na sua distribuição e menor pobreza absoluț. Para o Estado de São Paulo, segundo Kiyuna (1989), e o Estado de Santa Catarina, segundo Zanchet (1990), estas relações foram distintas.

$\mathrm{Na}$ agricultura do Estado de São Paulo, apesar da modernização estar associada ao aumento da renda média e `a diminuição da pobreza absoluta, foi observada a ausência de uma relação com significância estatística entre a modernização e a desigualdade da distribuição de renda.

No Estado de Santa Catarina as associações obtidas para outros Estados não foram estatisticamente comprovadas, não sendo constatada uma relação significativa entre a modernização e as características da distribuição de renda. Neste Estado, onde a estrutura de posse da terra se destaca no cenário nacional por apresentar um dos mais baixos índices de Gini, foram feitas também associações entre a distribuição de renda e a distribuição de posse da terra. No período 1970-1980 houve no Estado um aumento da desigualdade da distribuição da posse da terra, porém como no caso da modernização, não foi encontrada uma 
relação significativa entre a desigualdade da distribuição da posse da terra e as características da distribuição de renda.

Nos Estados do Mato Grosso e Mato Grosso do Sul, com características de uma estrutura agrária altamente concentrada, segundo Tarsitano (1990), todas as microrregiões homogêneas apresentaram no período 1970-1985 um grau de modemização (maior ou menor) ao lado de uma diminuição na concentração da posse da terra, com o aumento da área média, sendo exceção a microrregião homogênea de Bodoquena (MS). Até 1970 houve uma tendência de aumento da desigualdade da posse da terra, mas entre 1970 e 1985 os dois Estados apresentaram uma diminuição na desigualdade, apesar do grau de desigualdade da posse da terra ainda manter-se elevado, principalmente no Estado do Mato Grosso. Nos 55 municípios do Estado do Mato Grosso do Sul, entre os anos de 1970 e 1980, as relações entre modernização, renda média, pobreza absoluta e desigualdade da distribuição de renda apresentaram, segundo Andrade (1989), resultados semelhantes aos demais estudos associando estas variáveis, apresentando também, os municípios deste Estado, uma relação positiva entre a desigualdade da distribuição da posse da terra e a desigualdade da distribuição de renda.

No período 1981-1990, os dados da Pesquisa Nacional por Amostra de Domicílios (PNAD) para o Brasil, São Paulo e as regiões Centro-Oeste, Sul, Nordeste e Sudeste, mostraram que ocorreu um aumento do grau de concentração dos rendimentos obtidos do trabalho e incidência da pobreza. No Estado de São Paulo e na região Centro-Oeste, onde é maior a desigualdade da distribuição de renda é também mais elevado o rendimento médio, mas é menor a incidência de pobreza. No Nordeste onde a desigualdade é menor é bem inferior o rendimento médio e a pobreza é muito elevada.

Estas constatações feitas por Corrêa (1995) colocam a posição na ocupação 
como o fator mais relevante para a explicação da desigualdade, seguido da educação e região geográfica, tendo contribuição menor a idade e o sexo. No período 1981-1990, foram considerados também como condicionantes do crescimento da desigualdade e da pobreza, o crescimento inflacionário ocorrido no País na segunda metade da década de 80, e especialmente no Estado de São Paulo e região Centro-Oeste, a adoção do salário-mínimo como padrão de custo para a mão-de-obra agrícola assalariada.

Sabe-se também, que em decorrência do processo modernizante ocorreram transformações na composição da mão-de-obra rural, que são caracterizadas como um dos resultados da adequação deste mercado ao sistema capitalista introduzido no campo. No Brasil, segundo Hoffmann (1992), as modificações nas relações sociais de produção, decorrentes do intenso progresso técnico ocorrido na agricultura na década de 70 , se refletiram na crescente participação do trabalho assalariado na composição da mão-de-obra ocupada.

Para os anos de 1970 e 1980, os Censos Demográficos indicaram que excluindo da população economicamente ativa as pessoas não-remuneradas, cresceu a participação dos empregados e diminuiu a participação dos autônomos. A participação dos empregados aumentou de 31,8\% em 1970 para 46,0\% em 1980 e a dos autônomos diminuiu de 66,2\% para 50,9\%. As transformações sociais decorrentes da modernização no campo têm se traduzido em uma migração do setor rural para os setores industriais e de serviços. Se considerarmos a participação do pessoal ocupado na agricultura na população economicamente ativa, segundo dados publicados pela CEPAL (1995), poderemos verificar que esta diminuiu de 52\% em 1960 para 44,9\% em 1970 e 31,2\% em 1980.

Porém, de acordo com as diferentes fontes de dados existentes no País, o comportamento da composição da mão-de-obra no meio rural pode ser diferenciado. Em estudo sobre a composição da mão-de-obra no meio rural, na 
década de 80, Carvalho \& Bacha (1994) evidenciaram que existem diferenças substanciais conforme a fonte de dados utilizada, o que conduz a conclusões imprecisas sobre o real comportamento apresentado pelo mercado de trabalho na agricultura brasileira.

Segundo os autores, se consideramos os dados das PNADs, para as pessoas ocupadas no setor agrícola brasileiro, no período 1976-1989, verificaremos que ocorreu uma queda na participação relativa da categoria não remunerados, com o acréscimo relativo da categoria empregados. Entretanto, na análise por Estado, apenas os Estados do Maranhão, Paraíba, Sergipe, Bahia, Minas Gerais, Espírito Santo, São Paulo (exceto no período 1976-79), Santa Catarina e Rio Grande do Sul mostraram a tendência mencionada. O Estado do Ceará mostrou esta tendência apenas no período 1987-89. Portanto, devido aos padrões distintos de desenvolvimento agrícola, não se evidenciou um comportamento generalizado para todos os Estados brasileiros durante a década de 80 .

Ao considerar os dados dos Censos Agropecuários, os autores verificaram que para 1975-80 o número de pessoas ocupadas na agropecuária cresceu 4\%, enquanto entre 1980 e 1985 a expansão foi de $11 \%$. O aumento de pessoal ocupado no período 1975 e 1980 foi de pouco mais de 818 mil pessoas, enquanto entre 1980-85 atingiu mais de 2,3 milhões de pessoas. Com estas constatações, alguns autores, como Martine (1987), Silva (1987) e Mueller (1987), levantaram a suposição de que teria ocorrido um aumento do subemprego e da subocupação no campo.

Tais suposições foram refutadas por Carvalho \& Bacha (1994) ao constatarem que houve um aumento, entre 1980-85, da produtividade do trabalho no setor agropecuário brasileiro e nos seis Estados em que houve maior crescimento do emprego rural (Rondônia, Pará, Ceará, Paraíba, Bahia e Minas 
Gerais). Como não houve redução do salário relativo agricultura/mínimo e agricultura/servente, o crescimento do número de pessoas ocupadas na agropecuária não caracterizou uma situação de aumento da subocupação e subemprego no campo.

Na literatura é discutida também a questão fundiária que, apesar de não ter sido priorizada pelas políticas modernizantes adotadas, envolve relações com a distribuição de renda, as quais vêm sendo analisadas em diversos estudos que buscam subsídios ao desenvolvimento econômico. Segundo alguns autores, principalmente os pertencentes às primeiras correntes defensoras da reforma agrária, onde se destacaram Furtado (1972) e Guimarães (1977), seria no processo de formação da estrutura agrária que estariam as causas da concentração da posse da terra no Brasil. Para Guimarães (1977) as características feudais do processo de colonização brasileira, que ocorreu através da divisão das terras em lotes, as donatarias e sesmarias, levaram à concentração da posse da terra, da renda e ao atraso no desenvolvimento da agricultura.

As sesmarias até 1822 eram a forma legal de ocupação do território, porém ocorria de forma paralela o sistema de posses que multiplicava os pequenos agricultores. Entretanto, de 1822 em diante, apesar de ainda ocorrerem as ocupações de pequenos agricultores em lotes menores, passam a ocorrer as doações de terras públicas que viriam a originar os extensos latifúndios. No ano de 1850 alguns acontecimentos vieram a marcar a história da estrutura fundiária do Brasil: a promulgação da Lei de $n^{\circ} 601$, chamada Lei de Terras, e a regulamentação da imigração com a fundação de colônias e a criação de um órgão nacional denominado Repartição Geral das Terras. Este órgão tinha como objetivo fazer cumprir a Lei.

A Lei de Terras estabelecia em seu primeiro artigo a proibição das aquisições de terras por outro meio que não a compra, extinguindo o regime de 
posses. A Lei também buscava dificultar a aquisição de terras, através da elevação do seu preço, sendo o produto das vendas de terras destinado à imigração de colonos estrangeiros. Neste período também foi importante o papel desempenhado por algumas companhias colonizadoras, especialmente na região Leste de Santa Catarina.

Segundo Furtado (1988) foi justamente em 1850 que a Sociedade Blumenau \& Hackradt promoveu a fundação da colônia de Blumenau, constituída de alemães, às margens do rio Itajaí-Açu, cujo mérito deve-se ao Dr. Hermann Bruno Otto Blumenau. Inicialmente, as atividades desenvolvidas na região foram o cultivo do fumo e a agricultura de subsistência em pequenas propriedades, seguido do cultivo da cana-de-açúcar, que não se expandiu devido às condições de solo e clima. Foi considerado, então, como o maior impulso de desenvolvimento, o transporte fluvial iniciado entre Blumenau e Itajaí (1879) o que levou à instalação de indústrias, principalmente têxteis, que atualmente se constituem em um dos centros industriais do Estado.

Do mesmo período, também consta a ocorrência de uma colonização alemã no Vale do Rio Doce, no Estado do Espírito Santo, que apesar de ter-se dispersado, devido a forte influência de hábitos regionais instituiu ali, também, a divisão da terra em pequenas propriedades. Os resultados desta colonização se refletem nos indicadores de concentração de posse da terra que colocam estes dois Estados, Santa Catarina e Espírito Santo, como os que apresentam os mais baixos índices de concentração de posse da terra do País.

A estrutura de posse da terra foi considerada por Hoffmann (1967), entre outros, como um dos grandes obstáculos ao desenvolvimento econômico de alguns Países, entre eles o Brasil, pois especialmente nos Países subdesenvolvidos, a terra é considerada o principal componente do capital agrário (vide Censos Agropecuários). Os valores de índices de concentração da posse da 
terra calculados para o período 1940 a 1960 mostraram que a concentração de posse da terra no Brasil era elevada e aumentou de 1940 a 1960, com grandes variações de Estado para Estado e de região para região.

A concentração de posse da terra, no período, foi mais elevada nas regiões Norte e Nordeste e menos elevada nas regiões Sul e Sudeste. Os Estados que apresentaram menores índices de Gini foram o Estado do Espírito Santo e o Estado de Santa Catarina. Segundo o autor, resultados semelhantes foram obtidos por Câmara (1949), utilizando dados do Censo Agrícola de 1940, especialmente para o Estado de Santa Catarina que apresentou uma baixa concentração da posse da terra, o que estaria relacionado às políticas de colonização.

No período 1940-1960, Hoffmann (1971) constatou que apesar dos valores dos índices de Lorenz indicarem que teria havido um aumento da concentração fundiária, o conjunto de todos os demais índices calculados (índice de Gini modificado, redundância e índice de Theil), mostrou que não havia tendência para diminuir ou aumentar a concentração da posse da terra no País. Os índices de concentração da renda, para os dados de 1960 indicaram que a distribuição da renda era mais desigual na região Nordeste e menos concentrada no Sul, ocorrendo entre fins da década de 1950 e fins da década de 1960, um aumento na concentração da distribuição de renda no Brasil. Sendo a terra o principal componente do capital agrário no Brasil foram obtidas correlações significativas, para o período 1940-1960, entre os índices de concentração da renda no setor primário e os índices de concentração da posse da terra.

Para o período 1960-1980, a evolução da desigualdade da distribuição da posse da terra no Brasil foi avaliada também por Hoffmann (1982), através do índice de Gini, porcentagem de estabelecimentos menores do que a mediana (os $\left.50 \%^{-}\right)$e a porcentagem de estabelecimentos com área maior do que o $95^{\circ}$ percentil da distribuição (os $5 \%+$ ). Os três indicadores mostraram um 
crescimento pequeno, porém persistente para o Brasil como um todo. $\mathrm{O}$ índice de Gini aumentou de 0,842 em 1960 para 0,859 em 1980, a porcentagem da área total ocupada pelos 50 - diminuiu de $3,1 \%$ para $2,4 \%$ e a porcentagem da área total ocupada pelos $5+$ aumentou de $67,9 \%$ para $69,7 \%$. As regiões Nordeste e Sul apresentaram uma ligeira tendência de crescimento da desigualdade, a região Norte oscilações, porém predominou uma relativa estabilidade do grau de desigualdade.

Nas regiões Norte e Nordeste o índice de Gini, em geral, era maior do que 0,8 , a porcentagem da área ocupada pelos estabelecimentos menores do que a mediana era inferior a $4 \%$ e a porcentagem da área ocupada pelos $5+$ era superior a $60 \%$.

Neste período, novamente os Estados do Espírito Santo e de Santa Catarina destacaram-se como os que apresentaram graus de desigualdade menos elevados das regiões Sul e Sudeste e do Brasil, sendo as únicas unidades da federação onde a área ocupada pelos 50 - era superior a $10 \%$ de uma forma persistente. A explicação deste fato foi o processo de colonização ocorrido nestes Estados.

Apesar da relativa estabilidade do elevado grau de desigualdade da distribuição da posse da terra, no período 1960-1980, algumas regiões, tais como os Estados do Paraná e do Espírito Santo, apresentaram uma tendência de mudança cujas causas deveriam ser pesquisadas. Parte destas causas foram detectadas por Motta (1982), para o caso do Estado do Espírito Santo, como sendo um resultado da instalação do projeto Aracruz Celulose destinado à plantação de eucaliptos, que conduziu à extinção da pequena propriedade e o aumento da concentração fundiária com a diminuição da população rural.

Entretanto, ressalta-se o fato de que apesar dos Estados do Espírito Santo e de Santa Catarina apresentarem os mais baixos índices de desigualdade de distribuição da posse da terra do Brasil, (o Espírito Santo com um índice de Gini 
de 0,604 em 1970 e 0,660 em 1980 e Santa Catarina com 0,647 em 1970 e 0,676 em 1980) isto não significa que a posse da terra não esteja concentrada nestes dois Estados, já que estes valores são considerados como indicando concentração.

No caso específico de Santa Catarina, a situação fundiária não pode ser considerada a mais adequada também no que se refere a qualidade das terras. Dados do Instituto de Planejamento e Economia Agrícola de Santa Catarina (INSTITUTO CEPA/SC, 1984) indicam que a área mecanizável do Estado é de apenas $36 \%$, isto é, a maior parte das terras catarinenses é acidentada, imprópria ou difícil para ser utilizada em pastagens ou cultivo, destacando-se também o fato dos solos da maior parte do Estado necessitarem de contínuas correções de acidez para que possam ser obtidos melhores níveis de produtividade. Esta questão quando relacionada ao fato da maior parte dos estabelecimentos agropecuários de Santa Catarina serem pequenas propriedades, torna-se um problema que se traduz, muitas vezes, em falta de área disponível para a obtenção de um nível de produção que ofereça melhoria da renda e qualidade de vida dos agricultores. Esta situação levou às ações fundiárias que vêm sendo implementadas no Estado de Santa Catarina e que se enquadram no Plano Nacional de Reforma Agrária (PNRA) e no Programa Fundo de Terras.

O Programa Fundo de Terras, segundo Cazella (1995), visa justamente atender aos agricultores minifundiários. Foi criado e regulamentado em 1983 e a partir de 1992 foi incluído como instrumento de política agrária na Lei Agrícola de Santa Catarina, Lei $\mathrm{n}^{\circ} 8676$, em cujo artigo 32, parágrafo $1^{\circ}$, estão definidos como beneficiários do Programa Fundo de Terras, em primeiro lugar, os minifundiários; em seguida os trabalhadores rurais sem terra, os pescadores artesanais e, ainda, suas associações ou cooperativas. Este programa visa a compra e venda de terras para fins de reordenamento fundiário e de assentamento de agricultores, o que é uma das proposições da Organização das Nações Unidas 
para a Agricultura e Alimentação/Instituto de Colonização e Reforma Agrária (FAO/INCRA, 1994) para solucionar as necessidades de terra dos agricultores brasileiros de uma forma geral.

O Programa Fundo de Terras, uma política estadual, estaria então enquadrado nesta proposição da $\mathrm{FAO}$, pois o "ordenamento agrário visa atender jovens rurais e/ou agricultores com terras, mas em quantidade insuficiente, ou em regime de posse inadequado, tornando-os proprietários de unidades familiares de produção agrícola viáveis. Além disso, este tipo de ação objetiva prioritariamente, evitar que as terras que se encontram no mercado fundiário por razões diversas transferência do proprietário para outra região, abandono da atividade, aposentadoria, etc.- acabem nas mãos de proprietários não agrícolas, ou de grandes fazendeiros" (Cazella, 1995, p.41). Desta forma, constata-se que o Estado de Santa Catarina, apesar de apresentar um dos mais baixos índices de concentração da posse da terra e de ter sido colonizado principalmente a partir de pequenas propriedades, muitas vezes inviáveis, foi e é também alvo de políticas agrárias que visam melhorar as condições de vida dos agricultores. 


\section{O ESTADO DE SANTA CATARINA}

Neste capítulo está a descrição geral do Estado de Santa Catarina, sua economia, população, divisão territorial, o processo de 'colonização do Estado e os estudos relacionados à modemização de sua agricultura.

Economia - Santa Catarina é um Estado localizado na região Sul do Brasil. (vide Mapa 1). Sua atual extensão territorial de $95.442,9 \mathrm{~km}^{2}$ ocupa $1,12 \%$ do território brasileiro e sua população de 4,5 milhões de habitantes representa $3 \%$ da população total do País. É um dos menores Estados brasileiros ocupando respectivamente, o $20^{\circ}$ lugar em área territorial e o $11^{\circ}$ lugar em população. Segundo dados da Federação das Indústrias do Estado de Santa Catarina (FIESC, 1995) de 1985 a 1993 a economia catarinense apresentou uma taxa de crescimento média anual do Produto Interno Bruto (PIB) de 2,45\%. O PIB catarinense que era composto em 1985 de 14\% pelo setor primário, 45\% pelo secundário e $41 \%$ pelo terciário, passou a ser constituído em 1993 de $18 \%$ pelo setor primário, $43 \%$ pelo secundário e $39 \%$ pelo terciário, demonstrando um leve aumento de importância do setor primário no Estado. 
O Estado é o maior produtor brasileiro de alho, maçã, erva-mate cancheada, mel, carvão mineral, louça de mesa, cerâmica para revestimento, compressores, toalhas, tubos, conexões plásticas e ferro maleável; o segundo em cebola, pescado, fumo; e o terceiro em uva, banana, madeira, papel e papelão, mobiliário, produtos de matéria plástica, vestuário, calçados, artefatos de tecido, produtos têxteis e em número de cabeças de suínos e frangos.

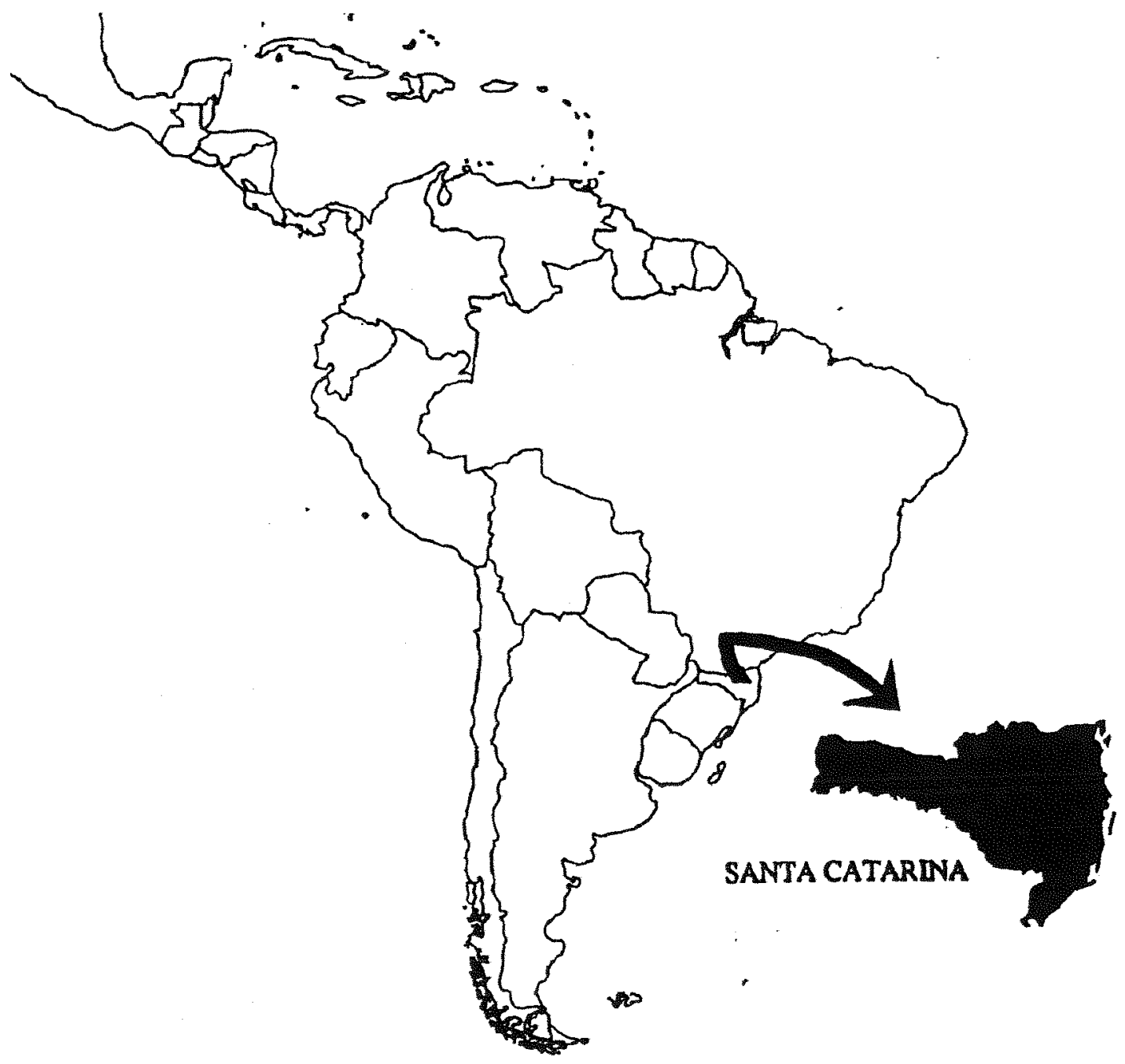

MAPA 1 - Localização geográfica do Estado de Santa Catarina 
População - Os dados relativos à população do Estado de Santa Catarina constam da Tabela 1. Em 1920, o $4^{\circ}$ Censo Geral da População (BRASIL, 1930) dividiu a população recenseada em profissões. A profissão predominante em Santa Catarina, assim como nos demais Estados da União, era a destinada a exploração do solo (agricultura, criação, caça e pesca) considerada então como a população que exercia profisssões rurais. Pode ser observado que a população catarinense era predominantemente rural até a década de 70. De um percentual de $78,06 \%$ em 1920 passou a 76,8\% em 1950, 57,06\% em 1970, 40,62\% em 1980 e 29,36\% em 1991. No período 1920-1950 o declínio da população rural foi pouco expressivo sendo mais intenso na década de 80.

Tabela 1. População total, urbana e rural do Estado de Sạta Catarina, 1920, 1950, 1970,1980 e 1991.

\begin{tabular}{lccccc}
\hline Ano & População Total & Urbana & Rural & \%Urbana & \%Rural \\
\hline 1920 & $213.105^{*}$ & 46.750 & 166.355 & 21,94 & 78,06 \\
1950 & 1.560 .502 & 362.717 & 1.197 .785 & 23,20 & 76,80 \\
1970 & 2.901 .734 & 1.246 .043 & 1.655 .691 & 42,94 & 57,06 \\
1980 & 3.627 .933 & 2.154 .238 & 1.473 .695 & 59,38 & 40,62 \\
1991 & 4.541 .994 & 3.208 .537 & 1.333 .457 & 70,64 & 29,36 \\
\end{tabular}

Fonte: BRASIL (1930)

Fundação Instituto Brasileiro de Geografia e Estatística (IBGE, 1951, 1973, 1982 e 1994)

*Este número inclui as pessoas com profissões que as definiram como pertencentes ao meio urbano e rural

Divisão territorial - Em 1920 o Estado estava dividido em apenas 34 municípios não havendo ainda uma divisão regionalizada dos mesmos. Em 1950, a divisão administrativa fixada para o qüinqüênio 1949/53, passa a ser composta por zonas fisiográficas e municípios obedecendo à divisão fixada pela resolução 
$\mathrm{n}^{\circ} 143$ de Julho de 1945 (IBGE, 1956). A divisão estadual estava composta de oito zonas fisiográficas, 52 municípios, 216 distritos, 52 cidades e 164 vilas. No período 1975/1985 a divisão regional ou territorial passa a ser baseada em mesorregiões, microrregiões homogêneas e municípios fixadas de acordo com o Decreto $n^{\circ} 67.647$ de Novembro de 1970. (IBGE, 1991, p.XI-XII).

De acordo com esta divisão havia no Estado de Santa Catarina no período 1975/1980, quatro mesorregiões, 16 microrregiões e 197 municípios. De 1980 a 1985 o número de mesorregiões e microrregiões não sofreu alterações, mas o número de municípios passou a 199. No período 1985/1991 o Estado passou a ser dividido em seis mesorregiões, 20 microrregiões e 217 municípios. Em 1994, os dados referentes a municípios divulgados pela FIESC (1995), mostraram que existiam 260 municípios instalados no Estado.

\subsection{Colonização}

O modo como ocorreu o processo de colonização do território catarinense teve como alicerce a pequena propriedade baseada na policultura, o que, supostamente, contribuiu para a atual situação do seu setor agropecuário e de sua economia global. Entretanto, segundo o INSTITUTO CEPA/SC (1978), existem inúmeras lacunas na literatura sobre a história econômica e social do Estado que enfoca, na maior parte dos casos, a sua história cronológica. Este fato, que ainda persiste na atualidade, levou ao desenvolvimento do presente capítulo que busca maiores conexões entre a história e a economia de Santa Catarina.

Historicamente, o processo de ocupação do território catarinense envolveu três grandes regiões: o Litoral, o Planalto e o Oeste (o Meio e o Extremo) que podem ser visualizados no Mapa 2. 


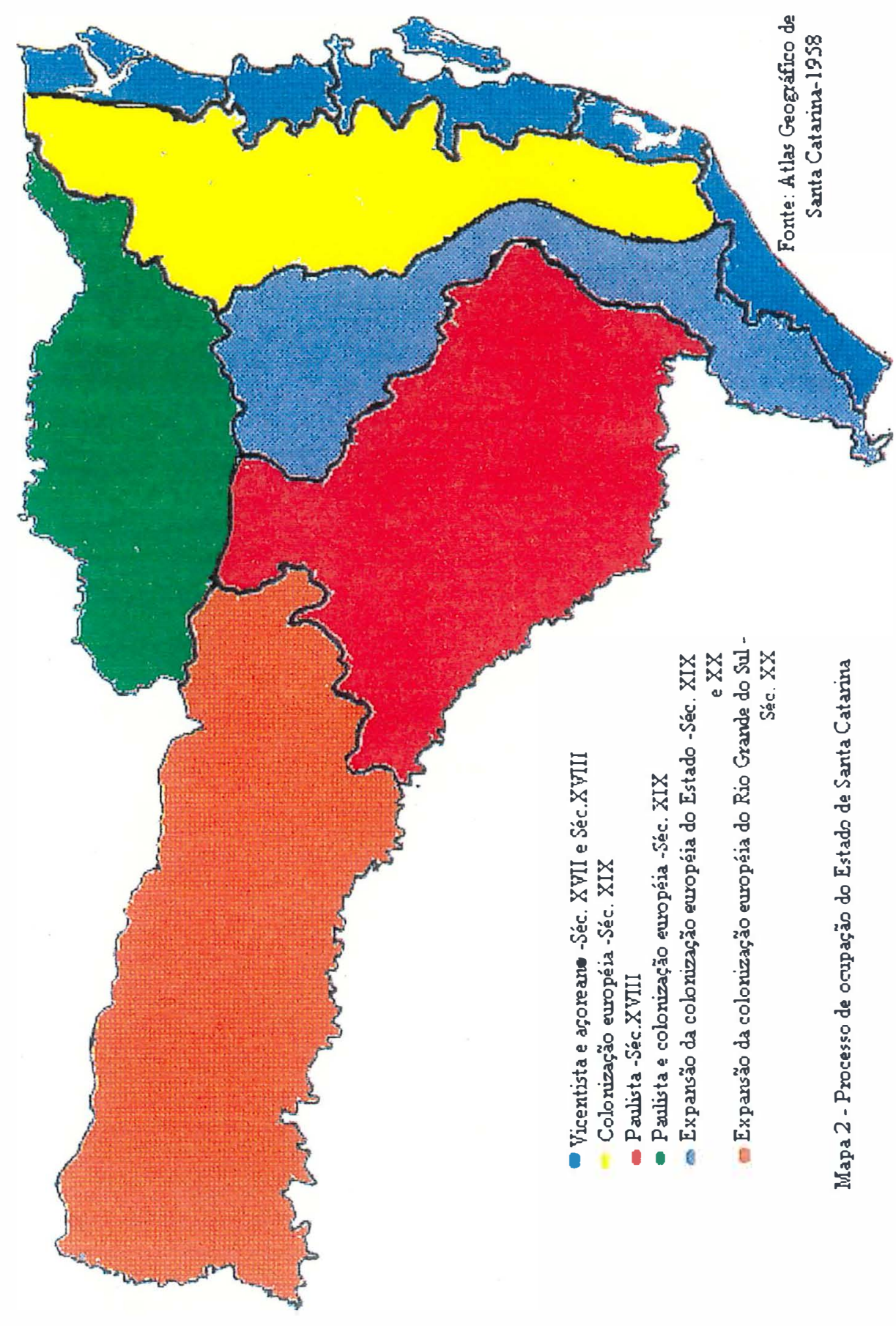


As populações colonizadoras se constituiram de vicentistas no século XVII, açorianos e paulistas no século XVIII, seguidas da colonização européia nos séculos XIX e XX e da expansão de colonos descendentes de europeus oriundos do Rio Grande do Sul no século XX.

Ocupação do Litoral - a ocupação do Litoral catarinense ocorreu através de três fluxos: os vicentistas no século XVI, os açorianos no século XVIII e os europeus (alemães, italianos e poloneses) no século XIX. Os vicentistas, oriundos de São Vicente e Piratininga em São Paulo, se instalaram na Ilha de São Francisco, em Desterro (atual Florianópolis) e Laguna e representavam as bases para a conquista portuguesa no Sul. Esta ocupação serviu de apoio logístico às atividades militares, devido aos conflitos com a Espanha, que também buscava o controle da região. Este processo veio associado ao aprisionamento de índios, busca de minérios, prata oriunda do Peru, e acesso ao rio da Prata.

A forma de organização das atividades econômicas adequou-se à natureza da ocupação, sendo assim: “do ponto de vista de Portugal,..., Florianópolis representava uma base através da qual trocava-se víveres por pólvora, sal e roupas velhas.... por volta de 1700 , Florianópolis produzia excedentes em farinha de mandioca, enquanto Laguna comercializava peixe seco e farinha. São Francisco, por seu turno, possuia lavoura de algodão e cana-de-açúcar. Aparentemente a forma de organização da produção era artesanal com leves indícios de escravagismo bem como pouco excedente agrícola comercializável" (INSTITUTO CEPA /SC, 1978, p.17).

As povoações vicentistas, em fins do século XVII e início do século XVIII, foram consideradas por esta referência bibliográfica como não tendo sìdo bem sucedidas nos seus objetivos, com Florianópolis se tornando centro contrabandista, Laguna beirando à extinção e São Francisco ligando-se à Vila de 
Paranaguá. Entretanto, segundo o Centro de Assistência Gerencial de Santa Catarina (CEAG/SC, 1980) é referenciado que Desterro e Laguna cumpriram o seu papel: Desterro como base militar estrategicamente importante, além de ponto de aguada para a demanda do Sul, e Laguna como entreposto para a exportação de gado. A importância estratégica de Desterro induziu a que se criasse a capitania subalterna de Santa Catarina (1738) diretamente subordinada ao Rio de Janeiro. A criação da capitania representou o aumento das exigências de excedente para as funções político-burocráticas, levando ao aumento do contigente produtor, o que teria sido a motivação da colonização açoriana.

O povoamento açoriano deu-se ao redor do século XVIII (1748-1756), abrangendo Desterro e o continente, indo de São Miguel às vizinhanças de Laguna. O contingente açoriano era basicamente constituído de pequenos agricultores e pescadores e serviu também às atividades militares, além das econômicas. O sistema fundiário imposto foi o de pequena propriedade, isto porque, segundo Piazza (1970), estas propriedades tinham em média 27 hectares.

A pesca, antes destinada a subsistência, passa a ter caráter mercantil, em especial a pesca da baleia. Em 1776 a pesca foi liberada, o que teria levado `a crise na primeira metade do século XIX, devido à competição estrangeira, culminando em seu fim. A produção de farinha de mandioca também foi importante, principalmente no século XVIII, quando foi a atividade mais rentável. Entretanto, a exportação da farinha dependia da flutuação da demanda de outras regiões. Os açorianos e vicentistas passaram pelo mesmo tipo de dificuldades, sendo que alguns fatores impediram a introdução das atividades manufatureiras: o atraso científico cultural das populações vicentistas e açorianas, as políticas impostas pela metrópole que restringiam tais atividades, assim como o seu isolamento das regiões mais importantes do País. 
Além dos colonos portugueses, segundo o INSTITUTO CEPA/SC (1978), outros imigrantes europeus ocuparam o Estado, mais destacadamente os alemães, italianos e poloneses que se instalaram em especial no Litoral do Estado se expandindo após para regiões próximas ao Litoral. A colonização estrangeira teria sido uma alternativa do governo imperial no sentido de preencher um vazio populacional próximo ao eixo de decisão política representando, também, a possibilidade de melhoria da capacitação dos recursos humanos com um baixo custo social para o País.

O primeiro contingente a chegar no País foi o de alemães, os quais fundaram a colônia de São Pedro de Alcântara em 1829, nas proximidades de Florianópolis, e duas décadas depois se estabeleceram no Norte do Estado, ao longo da Mata Tropical Atlântica especialmente no Vạe dos Rios próximo ao Litoral. São destaques a fundação da colônia Dona Francisca em 1851, atual cidade de Joinville, e as colônias do Vale do Itajaí em 1850, que originaram as cidades de Blumenau e Brusque. Em 1836 inicia-se a colonização italiana, na bacia do rio Tijucas, que originou os municípios de Nova Trento e Nova Itália; em 1875 os imigrantes italianos se instalaram no Litoral Sul do Estado originando, entre outros, o município de Criciúma.

A colonização polonesa ocorreu a partir de 1882, sendo os pontos de chegada no Litoral: Laguna, Florianópolis, Itajaí e São Francisco, contribuindo para a formação dos municípios de Turvo (1882), Orleães (1890), Grão-Pará (1900), Major Gercino (1895) e Guaramirim (1890). Esta colonização de alemães, italianos e poloneses no Litoral catarinense apresentou duas etapas distintas: a primeira, de 1829 a 1850, era de organização oficial, com características militares, e a segunda, a partir de 1851, chamada de instalação das Grandes Colônias, onde a iniciativa e a organização são tipicamente privados, exceção feita à cidade de Brusque. 
É importante ressaltar que muitas destas colônias receberam volumosas ajudas em infra-estrutura, mesmo sendo de organização privada, representando, assim, maior atenção às colônias estrangeiras, principalmente as alemãs, pois o mesmo parece não ter ocorrido com os fluxos italianos e poloneses, o que deve ter contribuído para o avanço econômico destas colônias: "por exemplo, em 1851 ano de sua implantação - a colônia Dona Francisca (hoje Joinville) já contava com $25 \mathrm{~km}$ de caminhos, constituídos às expensas do governo imperial......proporcionalmente, as colônias de Joinville, Blumenau e Brusque receberam muito mais do que a colônia nacional de Angelina" (INSTITUTO CEPA /SC, 1978, p.38).

As vantagens também são evidentes quando cada colono poderia ser dono de mais de um lote de terra, de tamanho variável entre 20 e 37,5 hectares, e sob diferentes formas de pagamento cujos solos eram mais férteis e cujo clima não parece ter sido um obstáculo ao crescimento econômico. As atividades de policultura associadas à criação de animais, desenvolvidas por estes imigrantes, são características que ainda perduram na atualidade.

Ocupação do Planalto - o processo de ocupação do Planalto Catarinense e sua ligação com a ocupação do Vale do Rio do Peixe e a região Oeste Catarinense são avaliados em publicações do INSTITUTO CEPA/SC (1978 e 1990) e CEAG/SC (1980). A princípio, o Planalto Catarinense era apenas caminho para a passagem do gado gaúcho servindo de ligação das "vacarias" ao Sudeste e Centro-Oeste do Brasil. A cidade de Laguna se constituia, neste período, no ponto de partida para a conquista do Rio Grande sendo o primeiro caminho do gado sulino em direção a Minas Gerais, através de São Vicente ou São Paulo (via marítima). Com a descoberta do caminho do Morro dos Conventos, por volta de 1720, que atingia o Planalto de Lages, Laguna perde a sua importância. A rota 
terrestre foi chamada "Caminho do Sul" e fazia ligação entre Vacaria-LagesMafra dali partindo o gado para a feira de Sorocaba em São Paulo, o que perdurou até o século XIX.

O grande impulso ao processo de ocupação regional foi a fundação de Lages, em 1771, ligada também ao chamado "tropeirismo" e a formação das estâncias (grandes propriedades) obtidas através da concessão de sesmarias, unidades típicas do Planalto cujas marcas estão presentes ainda hoje. Ao longo do "Caminho do Sul" se instalaram as correntes povoadoras do Planalto. A Oeste surgem pastagens de invernada e criação originando os municípios de Curitibanos e Campos Novos e nos campos naturais do Oeste e do Vale do Rio do Peixe, oriundos dos Campos de Guarapuava, outra corrente povoadora. A partir do Rio Grande do Sul ocorre uma nova frente de fazendeiros e sobreviventes da Revolução Farroupilha (1835-45) e posteriormente da Revolução Federalista de 1893 (Piazza, 1983). A estrutura de latifúndio passa a ser predominante no Planalto, se tornando uma exceção no contexto estadual, com uma nítida estratificação social. A heterogeneidade social, resultante da forma de ocupação inicial do Planalto, irá se refletir no movimento político e social denominado de "Contestado" que marcou a colonização do Oeste Catarinense.

Ocupação do Meio e Extremo-Oeste - a princípio, a região do Oeste Catarinense foi disputada pela Argentina e pelo Brasil na chamada "Questão das Missiones" ou "Palmas", que foi resolvida em 1903, com o Brasil como vencedor da questão. O conflito levou à instalação da colônia militar de Chapecó (atual Xanxerê) em 1882 o que influenciou o processo colonizador que viria a ser concretizado nas décadas de 1910 e 1920. Esta região também foi palco de conflitos com os indígenas e local onde ocorreu um dos mais importantes movimentos políticos e sociais do meio rural brasileiro, a chamada guerra do 
"Contestado" que perdurou de 1912 a 1916. Pelo ângulo político, o "Contestado" representou a disputa pelas áreas do Vale do Rio do Peixe parte do Planalto de Lages e do Planalto Norte, entre os Estados do Paraná e Santa Catarina e que envolvia interesses ervateiros e madeireiros dos dois Estados. Pelo ângulo social, as origens deste movimento se encontram na construção da estrada de ferro São Paulo-Rio Grande, cuja construção foi autorizada em 1893 e que também foi considerada como marco de colonização do Oeste.

O objetivo principal da construção da estrada de ferro São Paulo-Rio Grande era o transporte de produtos gaúchos, erva-mate e madeira do Paraná e Santa Catarina. Seu controle acionário foi absorvido em 1907 pela Brazil Railway Company que recebeu como concessão 15 quilômetros em cada lado dos trilhos da estrada, desconsiderando qualquer posse anterior. Com o compromisso de colonizar as terras chegaram à região, trazidos pela empresa para trabalhar na estrada, cerca de 10.000 pessoas de variada etnia e camadas sociais. Estas pessoas ao serem concluídas as obras da estrada ficaram abandonadas à própria sorte criando as bases sociais para a eclosão do "Contestado", isto é, a miséria das populações e a impossibilidade de reconhecer legalmente as propriedades de posseiros da área teria sido uma das causas do conflito. $\mathrm{O}$ aspecto social do "Contestado" chegou a envolver 20.000 caboclos, 6.000 soldados e 1.000 vaqueanos cujo desfecho deu-se em 1915, através da ação do exército. O aspecto político, que envolvia a contestação de terras pelos Estados do Paraná e Santa Catarina, teve seu desfecho em 1916, após várias contestações judiciais, determinando a atual delimitação territorial dos dois Estados.

A colonização do Vale do Rio do Peixe e do Oeste Catarinense, apesar de ser concretizada a partir da construção da estrada de ferro São Paulo-Rio Grande, já tinha sido iniciada com os sobreviventes da Revolução Farroupilha (1835) e Federalista (1893) a partir dos Campos de Lages e no sentido do Oeste formando 
fazendas de gado que se estendiam dos Campos de Guarapuava para os de Palmas, Campo Erê e Irani. A partir de 1911, após tentativas não bem sucedidas de colonização e em áreas contestadas pelo Paraná e Santa Catarina, o governo autorizou que as terras obtidas pela construtora, por concessão, fossem vendidas em grandes glebas a empresas colonizadoras particulares.

Segundo a literatura, é relevante destacar que esta foi a forma escolhida pelo governo para colonizar as terras, sendo o tamanho médio das propriedades independente de qualquer critério: "este caso aparentemente isolado é, na verdade, a forma geral de colonização escolhida pelas autoridades estaduais. $\mathrm{Ou}$ seja, uma determinada empresa encarrega-se de construir estradas e como pagamento recebe terras devolutas. Desta forma organizam-se empresas colonizadoras que tem como instrumento de receita e lucro a venda de terras a colonos. Em conseqüência, os tamanhos médios das propriedades vendidas aos colonos independiam de condições naturais nem se apoiavam em qualquer embasamento científico-econômico. Os tamanhos médios dos lotes variavam de 21 a 25 hectares" (INSTITUTO CEPA/SC, 1978, p.54).

Devido à escassez de terras que já o corria no Estado do Rio Grande do Sul, foram fundadas as colônias de Rio das Antas e Erval com imigrantes gaúchos. Os atuais municípios de Concórdia, Itá e Seara foram os primeiros estruturados com o padrão de colonização que veio a perdurar posteriormente. Em 1917, são criados os municípios de Cruzeiro (atual Joaçaba) e Chapecó. As empresas de Santa Catarina passaram a transferir suas concessões as empresas colonizadoras que se formavam no Rio Grande do Sul. Assim, os colonos descendentes de imigrantes alemães e italianos ocuparam a região ao longo do Rio do Peixe. A forma de colonização era a mesma, as empresas colonizadoras exploravam a madeira das terras e vendiam os lotes de cerca de 24 hectares aos colonos. As áreas de 100 a 1000 hectares eram destinadas especificamente às atividades 
agropastoris e extrativistas.

Após a resolução do "Contestado", em 1916, são ocupados o Meio e Extremo-Oeste, principalmente a partir da década de 20 , sendo que extensas áreas do Extremo-Oeste pertenciam à construtora da estrada de ferro São Paulo-Rio Grande. O processo migratório para esta região estendeu-se até a década de 60 , se constituindo basicamente de descendentes de italianos e alemães oriundos de colônias do Noroeste do Estado do Rio Grande do Sul. A principal atividade desenvolvida por estes colonos era a criação de porco tipo banha, além das culturas de subsistência. Segundo o INSTITUTO CEPA/SC (1978), este sistema de produção gerava excedentes que eram enviados ao seu Estado de origem, o Rio Grande do Sul, o que impulsionou o crescimento desta região.

A criação de suínos gerou no transcorrer do processo de ocupação a instalação de pequenos matadouros, levando a "uma integração setorial regional" resultante da expansão do envio da produção excedente para grandes centros urbanos como Curitiba, São Paulo e Rio de Janeiro. Em seqüência, são instalados os frigoríficos de aves e suínos que passam a substituir o suíno tipo banha pelo suíno tipo carne. Através do uso de tecnologias modernas e a agricultura por contrato, este setor veio a se tornar um dos setores industriais mais dinâmicos da economia estadual.

A ocupação do território catarinense, iniciada no século XVII, ainda na década de 1970 era alvo atrativo de migrantes, sendo observada, neste período, a migração de agricultores descendentes de japoneses para a região do Planalto. $\mathrm{Na}$ atualidade, os resultados de todo este processo de colonização podem ser verificados através do destacado setor industrial e da distribuição das atividades produtivas pelo território catarinense. O setor de indústria ocupa todo o Estado e está dividido, segundo a FIESC (1995), em cinco grandes complexos, constantes 
do Mapa 3, e que são classificados de acordo com o Valor da Transformação Industrial (VTI) em:

-no Sul está o complexo mineral, composto pela indústria extrativa mineral e produtos de minerais não metálicos, carvão e cerâmica para revestimento, que representa $9 \%$ do VTI, sendo também representativa nesta região a cultura do fumo ligada ao setor industrial;

-no Norte está o complexo eletro-metal-mecânico, fundidos de ferro, motocompressores, motores elétricos e refrigeradores, representando $18 \%$ do VTI;

-no Vale do Itajaí se localiza o complexo têxtil é do vestuário, calçados e artefatos de tecidos, que representa $25 \%$ do VTI;

-no Planalto está o complexo florestal (madeira, mobiliário, papel e papelão) que representa $14 \%$ do VTI e;

-no Oeste, o complexo agroindustrial de frangos, suínos, milho e soja, que representa $19 \%$ do VTI;

É no segmento agroindustrial, localizado principalmente na região do Oeste Catarinense, que ocorre a integração entre a agricultura, a pecuária e a indústria, representados respectivamente pelas culturas do milho e soja, a criação de suínos e aves e a indústria frigorífica. 


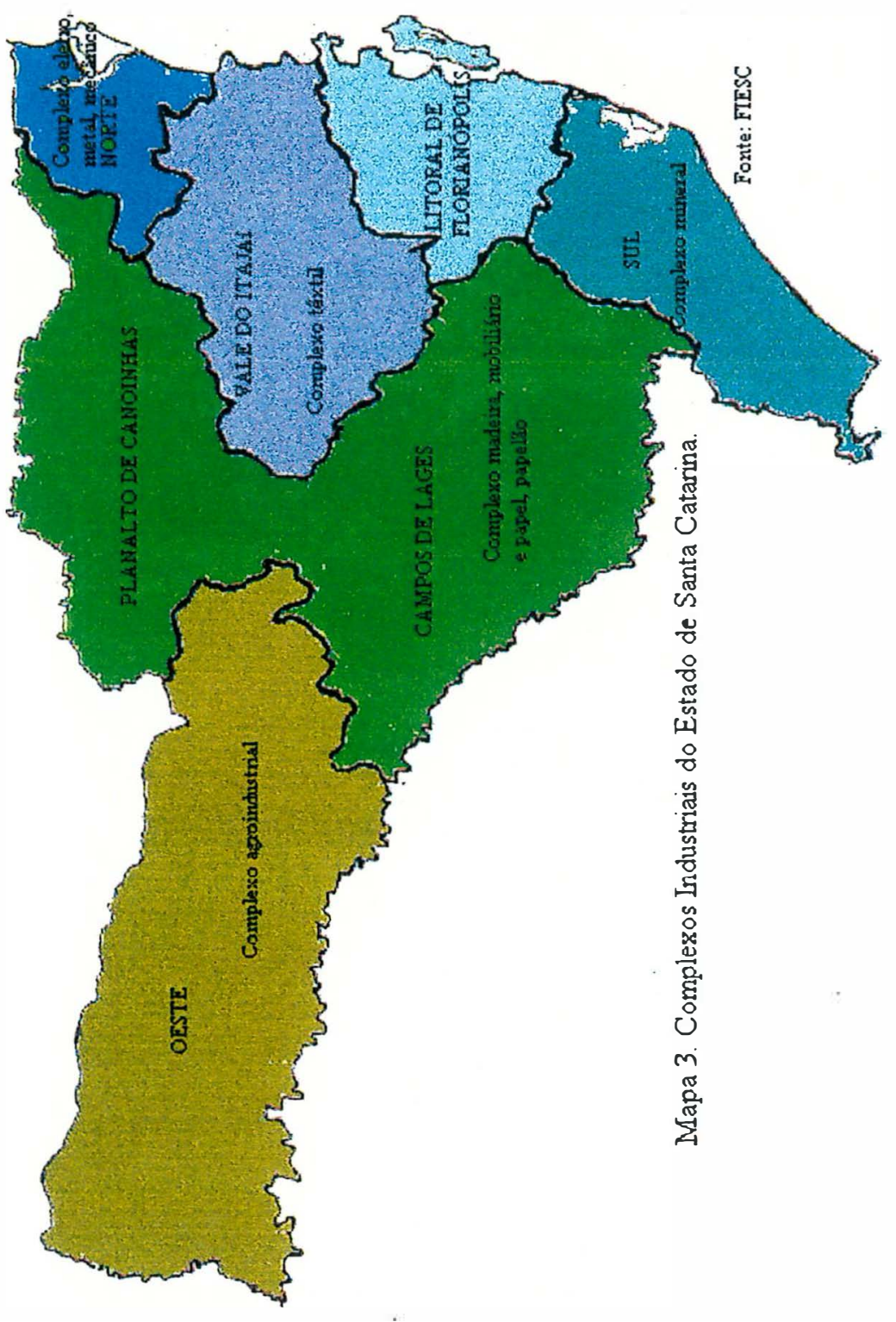




\subsection{A modernização da agricultura em Santa Catarina}

O Estado de Santa Catarina, como já exposto, se insere no contexto nacional de modernização da agricultura pelas suas características de colonização e posse da terra e também pela presença das agroindústrias, que vieram a influir nas concessões do crédito rural ao Estado. Entretanto, os estudos envolvendo o Brasil colocaram este Estado, de uma maneira geral, para os dados do Censo Agropecuário de 1975 e do Censo Demográfico de 1980, como um dos Estados que apresentavam menor grau de modemização da agricultura, com um grau de intensidade de exploração da terra relativamente alto e um grau relativamente baixo de mecanização e de modernização das relações de trabalho, fato associado à importância da pequena produção familiar tecnificada, em especial a relacionada à produção de cames (Hoffmann \& Kageyama, 1985).

Por outro lado, na avaliação do impacto ocasionado pela expansão das culturas voltadas às alternativas energéticas e à exportação sobre a agricultura de alimentos e com dados de 1970 e 1975, relativos ao número de tratores, ocupação da mão-de-obra por categoria, estrutura fundiária e utilização das terras, Hess et al. (1983) ao dividir o Estado em quatro regiões denominadas de Litoral Norte, Litoral Sul, Planalto e Oeste, constataram a adequação da expansão do progresso técnico às condições de produção na agropecuária catarinense, sendo a modernização considerada como tendo ocorrido de forma uniforme no Estado.

Entretanto, no estudo de Hoffmann \& Kassouf (1989), com os dados dos Censos Agropecuário e Demográfico de 1980, o Estado foi descrito novamente como em situação de relativo atraso da modernização da agricultura.Ao avaliarem a intensidade de exploração da terra, a produtividade do trabalho e a produção familiar com o uso de tração animal, verificaram ser maior a identificação com a 
produção familiar e o uso da tração animal em sete das 16 microrregiões homogêneas do Estado.

Vista sob um ângulo mais antropológico e especificamente para o Sul do Estado, a modernização de Santa Catarina foi avaliada por Paulilo (1990). No seu estudo o número de tratores foi considerado como um dos indicadores da "rapidez" do processo de modernização. Os dados do INSTITUTO CEPA/SC (1984), referentes às mudanças ocorridas no Estado no período 1960-1980, mostraram que o aumento dos valores reais das máquinas agrícolas, dos investimentos realizados e das despesas de custeio para a produção agrícola foram respectivamente de $2448 \%$, $574 \%$ e $1530 \%$. No caso particular dos tratores, uso de fertilizantes, ração e produtos veterinários, os valores foram $2893 \%, 3000 \%$ e $2800 \%$.

Segundo a autora, um dos fatores que teriam facilitado a modernização do Sul do Estado, caracteristicamente produtor de fumo, foi o crédito bancário, principalmente o destinado aos produtores ligados às agroindústrias de fumo. Outro fator muito importante foi a ação da Associação de Crédito e Assistência Rural de Santa Catarina (ACARESC) ${ }^{3}$ criada nos anos 50 e que além da assessoria e serviços de extensão prestados aos agricultores de todo o Estado, colocou em ação um programa de educação do jovem rural, os chamados clubes $4 \mathrm{~S}^{4}$ que significam respectivamente: Saber (Head), Sentir (Heart), Servir (Hand) e Saúde (Health). Nestes clubes, os filhos de agricultores na faixa etária entre $14 \mathrm{e}$ 25 anos, além de terem um local de reunião e diversão, recebem uma educação modernizante com acesso a pequenos créditos, com juros baixos, oriundos do Banco do Estado de Santa Catarina (BESC) com a finalidade de junto com os

\footnotetext{
${ }^{3}$ Atualmente integrada a Empresa de Pesquisa Agropecuária e Extensão Rural de Santa Catarina (EPAGRI)

4 Baseado nos clubes $4 \mathrm{H}$ dos Estados Unidos da América
} 
técnicos fazerem experiências nas propriedades dos pais.

Verifica-se a partir destas colocações que o Estado de Santa Catarina, apesar de não ser considerado como um dos mais modernizados do País, mostrou um crescimento rápido, no que se refere ao Sul do Estado, relacionado ao uso de máquinas, especialmente tratores e crédito bancário.

Em uma análise mais específica, relativa ao período 1970-1980, para verificar o grau de modernização e suas relações com a distribuição de renda e posse da terra nas microrregiões homogêneas de Santa Catarina, Zanchet (1990) constatou que a modernização no Estado estava relacionada a três indicadores: propriedade familiar, criação modernizada, financiamentos e uso intensivo de mecanização e insumos modernos.

A modernização, no período em questão, não ocorreu de maneira análoga nas diversas regiões do Estado, pois as microrregiões homogêneas com "alto grau" de modernização agrícola como Litoral de Itajaí, Colonial Sul Catarinense e Colonial do Rio do Peixe coexistiam com microrregiões homogêneas muito "atrasadas" como Litoral de Laguna. Sete regiões foram identificadas quanto ao grau de modernização: Litoral Norte e Florianópolis, Litoral de Itajaí, Vale do Itajaí e Sudeste Catarinense, Sul Catarinense, Planalto Catarinense, Vale do Rio do Peixe e Oeste Catarinense. As microrregiões onde se desenvolvem a cultura do fumo, aves e suínos, ligadas às agroindústrias, se encontram mais modernizadas juntamente com a microrregião homogênea Litoral de Itajaí, notadamente produtora de cana-de-açúcar.

Para o período 1970-1980, o mesmo estudo constatou que as relações sociais de produção apresentaram, em geral, poucas alterações não desaparecendo a unidade de produção familiar e o trabalho familiar. $\mathrm{O}$ assalariamento agrícola ocorreu em menor escala do que em outras regiões do País devido, provavelmente, ao tipo de contrato estabelecido entre o produtor e a agroindústria. 
Entretanto, foi considerado não haver contradições entre propriedade familiar e modernização nas principais regiões agrícolas de Santa Catarina. Porém, ocorreu um aumento da desigualdade de distribuição da posse da terra no Estado não tendo sido considerados estatisticamente significativos os efeitos da modemização e da distribuição da posse da terra sobre as características da distribuição da renda, isto é, não houve tendência do que foi considerado como modernização vir acompanhado do aumento da desigualdade da distribuição de renda.

As prováveis causas apontadas para o grau relativamente baixo de desigualdade da distribuição da renda obtido para o Estado teriam sido a relativa homogeneidade dos dados e o pequeno número de observações (apenas 16 microrregiões) assim como a presença do setor industrial e dos oligopólios agroindustriais.

A microrregião homogênea Litoral de Itajaí teria se destacado, no período 1975-1980, segundo Hoffmann (1992), pela intensa modernização associada a formação de lavouras de cana-de-açúcar tecnificadas. As microrregiões Colonial de Joinville, Florianópolis e Colonial do Rio do Peixe também teriam apresentado uma modernização relativamente intensa. Destaca-se que a microrregião Colonial do Oeste Catarinense apresentou grande aumento da intensidade de exploração da terra e uma diminuição da relação capital/trabalho. Entre 157 microrregiões homogêneas brasileiras, esta microrregião foi a que apresentou menor valor do fator em 1980. Várias microrregiões apresentaram relação capital/trabalho bastante reduzida com a predominância da agricultura familiar no Estado.

Em 1975, as microrregiões que apresentaram maior grau de modernização com relação à capacidade produtiva da força de trabalho e à modernização das relações sociais de produção (assalariamento), grau de monetarização da produção e grau de mecanização, segundo Espírito Santo (1995), foram Litoral Sul Catarinense e Colonial do Sul Catarinense, produtoras de fumo e as de menor 
grau de modernização Colonial Serrana Catarinense, produtora de fumo e Litoral de Laguna, produtora de pescado. Em 1985, somente Litoral de Itajaí, então produtora de pescado e cana-de-açúcar, foi incluída no grupo de maior modernização sendo excluída do grupo de menor modernização a microrregião Colonial Serrana Catarinense.

As microrregiões captadoras de recursos financeiros de forma significativa foram as que concentram as agroindústrias de fumo (Litoral e Colonial do Sul Catarinense), suínos e aves (Colonial do Rio do Peixe e do Oeste Catarinense). Entretanto, as regiões onde predominam a avicultura e a suinocultura apresentaram um menor grau de modernização das relações sociais de produção (assalariamento) do que algumas regiões produtoras de fumo. Isto porque ocorreu naquelas microrregiões uma "transformação parcial" das relações sociais de produção. Este fato se pressupôs explicável pela expansão da avicultura industrial e ao tipo de contrato feito entre o produtor e a agroindústria, que manteve as pequenas propriedades que se utilizam basicamente da mão-de-obra familiar, enquanto nas regiões produtoras de fumo, cultura sazonal, o uso da mão-de-obra assalariada é maior.

Apesar de não termos encontrado estudos que pormenorizassem as análises sobre a modernização nos municípios do Estado de Santa Catarina, podemos constatar pelos existentes que a modernização de sua agropecuária vem sendo relacionada aos complexos agroindustriais de fumo, aves, suínos e cana-deaçúcar. 


\section{METODOLOGIA}

O capítulo de metodologia consiste da descrição dos procedimentos utilizados para a realização do estudo e consta de duas partes. Na primeira parte está o método específico de análise e na segunda parte está a descrição dos dados utilizados. O estudo segue uma ordem cronológica, considerando cinco cortes temporais: 1920, 1950 e o período 1975, 1980 e 1985.

\subsection{Método de análise}

Esta parte do estudo apresenta os métodos que foram utilizados e consta especificamente da análise fatorial ponderada, do cálculo das medidas de concentração da posse da terra e a forma de cálculo do pessoal ocupado na agricultura em equivalentes-homem.

\subsubsection{Análise Fatorial}

Para a identificação do grau de modernização existente nos municípios em cada um dos anos em estudo foi necessário utilizar uma metodologia que 
reduzisse o número de variáveis envolvidas e que se correlacionam, transformando-as em um conjunto de variáveis independentes entre si, que são os chamados fatores ou componentes, com um mínimo de perda de informação. Este processo facilita a compreensão das análises. O método de análise fatorial é o mais indicado neste caso e vem sendo utilizado por diversos autores como um método de análise da modernização da agricultura nas microrregiões homogêneas do Brasil sendo considerados pioneiros na sua utilização, no País, Mesquita et al. (1977) e Cunha (1978).

A literatura evidencia que existem vários métodos para se proceder a uma análise fatorial. Harman (1976) e Johnson \& Wichern (1982), por exemplo, indicam o método da máxima verossimilhança, o método dos fatores principais e o método dos componentes principais, também citados em Hoffmann (1994). A análise fatorial pelo método dos componentes principais é considerada a mais simples e foi a utilizada no presente estudo. Este método consiste, na realidade, de um conjunto de métodos estatísticos que é utilizado quando se tem um grande número de variáveis correlacionadas entre si, o que para Chatfield \& Collins (1980), ocasionaria o problema da multicolinearidade, pela associação entre as variáveis, não sendo possível o tratamento estatístico de regressão múltipla.

A análise fatorial consiste no desenvolvimento de equações cujo entendimento parte de $(l)$ observações e $(n)$ variáveis, com as quais construimos inicialmente uma matriz denominada matriz $\mathrm{X}$, cujos valores $x_{i j}$ (j-ésima observação da i-ésima variável) são obtidos a partir de:

$$
x_{i j}=\frac{X_{i j}-\bar{X}_{i}}{\sqrt{\sum_{j}\left(X_{i j}-\overline{X_{i}}\right)^{2}}}
$$


Este procedimento faz com que as variáveis passem a ter uma padronização das unidades de medida com média zero e soma dos quadrados de $x_{i j}$ igual a um.

É a partir da matriz X que ocorre a análise fatorial pelo método dos componentes principais e da qual se obtém as matrizes $R$, A e F. Da matriz $\mathrm{R}=\mathrm{XX}$, de correlações simples, são obtidos os fatores comuns ou componentes principais, os quais são combinações lineares das variáveis iniciais e que são organizados obedecendo a uma ordem decrescente para explicar a variância total dos dados originais.

Os componentes principais são obtidos utilizando-se as raízes características da matriz R. A cada componente principal corresponde uma raiz característica da matriz R. Estas raízes são colocadas em ordem decrescente e os seus valores indicam em qual valor os componentes principais explicam a variância total das variáveis $\mathrm{X}$. O primeiro componente principal é a melhor combinação linear para explicar a variância, o segundo componente é a segunda melhor combinação e assim sucessivamente até que a variância total seja explicada, mantendo-se a ortogonalidade entre eles.

Para a determinação do número de fatores, ou componentes principais, a serem utilizados na análise, costuma-se utilizar os componentes que apresentam raízes características maiores ou iguais a um, e que explicam a maior porcentagem da variância dos dados, assim substituindo os dados originais. Entretanto, segundo Hoffrnann (1992), os critérios de decisão de qual o número de fatores que devem ser extraídos não são absolutos, enquanto um menor número de fatores simplificaria e facilitaria a análise, um maior número de fatores explicaria uma maior proporção da variância total das variáveis originais enriquecendo a análise.

$\mathrm{Na}$ matriz A estão os coeficientes de correlação entre cada uma das variáveis e os fatores extraídos. Os coeficientes de correlação são chamados de 
cargas fatoriais. A denominação dos fatores consiste em considerar as variáveis que mais forte correlação apresentam com o fator; em geral, esta correlação é superior a 0,60. A proporção da variância de cada variável que é explicada pelos fatores comuns é a comunalidade desta variável, cujo valor quanto mais próximo de um, indica maior contribuição dos componentes para a variância total de cada variável considerada. A interpretação da comunalidade corresponde à interpretação do coeficiente de determinação $\left(\mathrm{R}^{2}\right)$ na análise de regressão sendo que uma baixa comunalidade indica que a variável não deve pertencer ao conjunto.

$\mathrm{Na}$ matriz $\mathrm{F}$ encontram-se os valores dos componentes principais transformados que relacionam as observações com os fatores. Como os fatores apresentam média ponderada igual a zero e variância igual a um, considerou-se uma escala para interpretar o grau de modernização das observações. Os valores negativos indicam antagonismo com relação aos fatores, enquanto valores positivos indicam concordância com os fatores. Valores superiores a 0,5 indicam elevado grau de associação com os fatores, enquanto valores que se situam entre zero e 0,5 estão associados a um grau médio de modernização. Entretanto, salienta-se que a análise dos valores das cargas fatoriais irá depender do contexto e do ponto de vista do pesquisador.

Para ser obtida uma estrutura simples, que facilite a interpretação dos fatores, é bastante utilizado fazer uma rotação ortogonal dos fatores possibilitando que os valores absolutos se aproximem de zero ou de um. Esta rotação pode ser feita através do método VARIMAX (Harman, 1976), que mantém a ortogonalidade entre os fatores, mas faz com que os fatores apresentem após a rotação forte correlação relativa com uma ou mais variáveis e fraca correlação relativa com as demais variáveis. $\mathrm{Na}$ rotação não é alterado o valor da comunalidade das variáveis e a contribuição conjunta dos fatores, mas é alterada a 
contribuição de cada fator na explicação da variância e a participação de cada uma das variáveis na explicação dos indicadores de modernização.

A análise fatorial utilizada no presente estudo foi a análise fatorial estática, que é feita em cortes temporais. Esta análise indica a posição relativa das unidades de observação em relação às variáveis com as quais os fatores tem elevada correlação, identificando-se, assim, as unidades mais modernas em relação às outras. Devido ao fato de estarmos trabalhando com municípios, cuja participação no contexto estadual é variável, constatou-se a necessidade da análise ser ponderada.

A variável de ponderação utilizada foi o número de pessoas ocupadas na agricultura constante dos Censos Agropecuários. A ponderação foi feita de acordo com os procedimentos utilizados em Hoffmann (1992), onde os valores da variável de ponderação são normalizados. Nesta normalização primeiro é feito o cálculo da média dos valores da variável de ponderação, de cada município em cada ano, sendo o número obtido utilizado como divisor de cada um dos valores da variável de ponderação. Os cálculos da análise fatorial foram feitos com 0 auxílio dos programas estatísticos Excel e SAS (Statistical Analysis System).

\subsubsection{Variáveis utilizadas na análise fatorial}

Dentro do desenvolvimento teórico, constante do capítulo de revisão de literatura, pôde ser constatado que o conceito de modernização da agricultura no Brasil esteve explicitamente relacionado a um conjunto de variáveis que conduziram a alterações da estrutura técnica produtiva e das relações sociais de produção, mais especificamente relacionado às políticas adotadas na década de 60. Para o período anterior a este ainda não havia sido estabelecido um conceito, ou padrão, do que poderíamos considerar como modernização, como o utilizado 
no período intenso de modernização pós 64, sendo que os Censos de 1920 e 1950 não contém muitas das informações que podem ser encontradas nos Censos de 1975,1980 e 1985 acerca do assunto.

Os dados coletados pelo Censo da Agricultura de 1920 não abrangeram informações sobre o valor das despesas de qualquer natureza, financiamentos, investimentos, valor da produção agropecuária ou a indicação do uso de adubos, corretivos, sementes, mudas e a área com pastagens plantadas e subdivisões do pessoal ocupado na agricultura em categorias; enquanto o Censo Agrícola de 1950 não traz o valor das despesas com medicamentos e alimentos, nem o valor dos investimentos e financiamentos, não constando também o valor da produção agropecuária. Em 1950 não existiam informações referentes ao uso de força mecânica em 50 dos 52 municípios existentes naquele ano.

Com o objetivo de identificar e qualificar o processo de modernização no Estado de Santa Catarina, e com as informações disponíveis nos Censos Agropecuários de cada ano em estudo, foram agrupados conjuntos de variáveis que através da análise fatorial pudessem definir: o tipo e grau de adoção de tecnologia, o valor dos financiamentos, investimentos e bens existentes nos estabelecimentos agropecuários, a intensidade de uso da terra, mão-de-obra e máquinas e as relações no mercado de trabalho. Para homogeneizar os dados referentes ao rebanho animal e a força de trabalho foi utilizada a conversão em unidades-animal e equivalentes-homem, como descrito a seguir.

$\mathrm{O}$ número de unidades-animal (UA) é utilizado no caso de estabelecimentos que criam vários tipos de animais. Para o cálculo do número total de unidades-animal é necessário que seja estabelecido um critério, como a quantidade de alimento requerido, a partir do qual se determina a equivalência entre os diferentes animais considerando uma unidade-animal como sendo, por exemplo, um bovino adulto (fêmea). Com base em metodologia de conversão 
recomendada por Hoffmann et al. (1984) e no conjunto da pecuária, pequenos animais e aves constantes dos Censos Agropecuários, foram consideradas as seguintes equivalências:

\section{Espécie animal}

Bovinos

Bubalinos

Eqüínos

Muares

Suínos

Ovinos

Caprinos

Coelhos

Galinhas e galos

Frangos e frangas

Perus e gansos

Patos, marrecos e codornas

\section{Número de unidades-animal}

1,00

1,00

1,00

0,70

0,30

0,20

0,20

0,01

0,01

0,01

0,03

0,03

$\mathrm{Na}$ força de trabalho foi utilizado o número de equivalentes-homem $(\mathrm{EH})$ que converte o número de pessoas em unidades homogêneas da força de trabalho. Um equivalente-homem pode ser definido como sendo a equivalência da força de trabalho com um assalariado do sexo masculino, adulto, durante os 300 dias do ano. As equivalências consideradas no estudo foram baseadas em conversões sugeridas por Kageyama \& Silva (1983) e nos dados censitários. Em 1920 a população estava dividida por profissões, segundo o sexo e a idade, nas diversas categorias de trabalho. Dos dados existentes foram utilizados os correspondentes 
a agricultura, criação, caça e pesca correspondendo um maior de 21 anos a 1,0 equivalente-homem, uma mulher maior de 21 anos a 0,6 equivalentes-homem, e os menores de 21 anos a 0,5 equivalentes-homem.

Em 1950 o pessoal ocupado na agricultura estava dividido em quatro categorias que seguiram as seguintes conversões:

Categoria de trabalhador

Responsável e membros não remunerados da família

Homens maiores de 15 anos

Mulheres maiores de 15 anos

Menores de 15 anos

Empregados permanentes e temporários

Homens maiores de 15 anos

Mulheres maiores de 15 anos

Menores de 15 anos

Parceiros(residentes e não residentes no estabelec.)

Homens maiores de 15 anos

Mulheres maiores de 15 anos

Menores de 15 anos
Número de equivalentes-homem

$$
\begin{aligned}
& 1,00 \\
& 0,60 \\
& 0,40
\end{aligned}
$$

1,00

1,00

0,50

1,00

0,66

0,40

Para os demais anos 1975, 1980 e 1985 os dados são um pouco mais abrangentes e exigiram além das conversões a seguir descritas alguns ajustes nas categorias de empregados temporários e serviços de empreitada: 
Categoria de trabalhador Número de equivalentes-homem

Responsável e membros não remunerados da família

Homens maiores de 14 anos

1,00

Mulheres maiores de 14 anos

0,60

Menores de 14 anos

0,40

Empregados permanentes e temporários

Homens maiores de 14 anos

1,00

Mulheres maiores de 14 anos

1,00

Menores de 14 anos

0,50

Parceiros (empregados)

Homens maiores de 14 anos

1,00

Mulheres maiores de 14 anos

0,66

Menores de 14 anos

0,40

Outra condição

Homens $\quad 1,00$

$\begin{array}{ll}\text { Mulheres } & 0,66\end{array}$

Com relação à categoria de empregados temporários, a definição constante dos Censos Agropecuários de 1975, 1980 e 1985, a coloca no conjunto do pessoal ocupado como sendo: "pessoas contratadas para execução de tarefas eventuais ou de curta duração, mediante remuneração em dinheiro ou sua equivalência em produtos, inclusive os membros da família desses empregados que os auxiliavam na execução de suas respectivas tarefas" (IBGE, 1991, p.XV), e em seguida define a utilização do pessoal temporário como sendo o número máximo de empregados temporários contratados, mês a mês, no respectivo ano de cada Censo, para execução de trabalhos eventuais ou de curta duração dos estabelecimentos. 
Sendo assim, foi necessário estimar o trabalho temporário considerando estas duas definições, que envolvem dois tipos de dados. Com os dados mensais, no respectivo ano de cada Censo, foi calculada a média anual de empregados temporários do estabelecimento, cujo resultado foi multiplicado pela proporção do trabalho temporário de homens e mulheres adultos e menores de 14 anos.

Os dados sobre o serviço de empreitada, que é um tipo de mão-de-obra contratada através de terceiros, e que não estão incluidos na categoria de pessoal ocupado, foram convertidos em equivalentes-homem através da divisão do total das despesas com empreitadas pelo valor correspondente a 300 dias de trabalho volante, isto é, a diária média multiplicada pelos dias trabalhados. Para o ano de 1985 as despesas com serviços de empreitadas foram obtidas de tabulações especiais do Censo Agropecuário. Para obter uma estimativa do emprego total na agricultura catarinense em cada ano, convertido em equivalentes-homem, foi feita a soma das categorias de pessoal ocupado consideradas.

Foi utilizado, também, o conceito de área explorada (AE), que nos Censos Agropecuários corresponde à soma das áreas com lavouras permanentes e temporárias, pastagens, matas e florestas plantadas (área trabalhada) e as áreas com pastagens, matas e florestas naturais. A seguir estão relacionadas as variáveis utilizadas no estudo dentro do grupo ao qual pertencem:

\section{Variáveis utilizadas na análise fatorial ponderada de 1920}

\section{1) Tipo e grau de adocão de tecnologia}

$\mathrm{TEC} 1$ = percentual de estabelecimentos que usam a força mecânica (hidráulica e a vapor)

TEC2 $=$ percentual de estabelecimentos que usam a força animal 
TEC3 = número de instrumentos agrários por área explorada

TEC4 $=$ percentual de estabelecimentos que possuem máquinas

TEC5 = número de máquinas por equivalente-homem

2)Valor dos bens existentes nos estabelecimentos

CAP1 $=$ valor das terras no valor total dos bens

$\mathrm{CAP} 2=$ valor das benfeitorias no valor total dos bens

CAP3 = valor das máquinas e instrumentos agrários por área explorada

3)Intensidade de uso da terra, mão-de-obra e máquinas

SAT1 = percentual de área trabalhada na área total dos estabelecimentos recenseados

$\mathrm{HECl}=$ hectares de área explorada por trator

HEC2 = hectares de área explorada por equivalente-homem

\section{4)Relacões no mercado de trabalho}

RMT1 = percentual de mão-de-obra masculina no total de equivalentehomem

RMT2 = percentual de mão-de-obra feminina no total de equivalente-homem

Em 1920 foram considerados como instrumentos agrários os arados, grades, semeadeiras, cultivadores, ceifadores e tratores; e, como máquinas, as máquinas de beneficiar (arroz, café, mate), fabricar (açúcar, manteiga), descaroçar algodão, moer cereais e outros. 
$\underline{\text { Variáveis utilizadas na análise fatorial ponderada de } 1950}$

\section{1) Tipo e grau de adocão de tecnologia}

$\mathrm{TEC} 1$ = percentual de estabelecimentos que usam a força animal

TEC2 = número de instrumentos agrários por área explorada

TEC3 = valor das despesas com adubos e fertilizantes por área explorada

TEC4 = valor das despesas com inseticidas e fungicidas por área explorada

TEC5 = número de instrumentos agrários por equivalente-homem

TEC6 = percentual de estabelecimentos que usam veículos de carga (tração animal)

TEC7 $=$ percentual de estabelecimentos que usam veículos de carga (motor)

TEC8 = número de arados de tração animal (aiveca) por área explorada

TEC9 = número de tratores por área explorada

\section{2) Valor dos bens existentes nos estabelecimentos}

CAP1 $=$ valor das terras no valor total dos bens

CAP2 $=$ valor das benfeitorias no valor total dos bens

CAP3 = valor das máquinas e instrumentos agrários por área explorada

CAP4 = valor dos veículos e animais de trabalho no valor total dos bens

\section{3)Intensidade de uso da terra, mão-de-obra e máquinas}

SAT1 = percentual de área trabalhada na área total dos estabelecimentos SAT2 = percentual de área com pastagens plantadas na área total com 
pastagens

$\mathrm{HECl}=$ hectares de área explorada por equivalente-homem

\section{4)Relacões no mercado de trabalho}

RMT1 = percentual da mão-de-obra familiar no total de equivalente-homem RMT2 = percentual da mão-de-obra permanente no total de equivalentehomem

RMT3 = percentual da mão-de-obra temporária no total de equivalentehomem

Em 1950 as máquinas e instrumentos agrários constam juntos na mesma categoria do Censo Agrícola. Porém, no presente estudo considerou-se os tratores como máquinas e os arados, grades, rolos, semeadeiras, pulverizadores, polvilhadeiras e ceifadeiras como instrumentos agrários.

Variáveis utilizadas na análise fatorial ponderada de 1975, 1980 e 1985

\section{1)Tipo e grau de adocão de tecnologia}

As políticas voltadas para a modernização da agricultura, implantadas na década de 60, incentivaram através de subsídios o uso dos chamados insumos modernos. Estes compreenderam o uso de sementes melhoradas, fertilizantes, corretivos do solo, defensivos (tanto vegetal como animal) e de força mecânica (máquinas, equipamentos e implementos em geral). Para definir quais destes insumos tiveram maior importância na agricultura catarinense as seguintes variáveis foram definidas: 
TEC1 = percentual de estabelecimentos que usam a força mecânica TEC2 = percentual de estabelecimentos que usam a força animal TEC3 = valor das despesas com adubos e corretivos por área explorada TEC4 = valor das despesas com sementes e mudas por área explorada TEC5 = valor das despesas com defensivos agrícolas por área explorada TEC6 = valor das despesas com medicamentos e alimentos por unidade-animal TEC7 = número de arados de tração animal por área explorada TEC8 = número de tratores por área explorada

2)Valor dos investimentos, financiamentos e bens existentes nos estabelecimentos

O modelo de modernização da agricultura dos anos 60 , mesmo no caso onde foram liberados poucos recursos, está relacionado com o uso de capital financeiro, através do incentivo ao uso dos chamados insumos modernos e aos investimentos em bens de capital em geral. A importância desta característica do mencionado modelo no Estado de Santa Catarina foi testada através de variáveis que expressam o valor dos bens existentes, dos investimentos realizados na aquisição de bens de capital e os financiamentos obtidos para investimento, custeio e comercialização nos estabelecimentos:

CAP1 = valor dos financiamentos por área explorada

$\mathrm{CAP} 2=$ valor dos investimentos por área explorada

CAP3 $=$ valor dos financiamentos por equivalente-homem

CAP4 $=$ valor dos bens em animais no valor total dos bens

CAP5 = valor dos bens em máquinas e instrumentos agrários por área explorada 
3)Intensidade de uso da terra, mão-de-obra e máquinas

O aumento da capacidade produtiva da força de trabalho (produção por equivalente-homem ou unidade-animal) e a intensificação do uso da terra (aumento percentual da área explorada, aumento da produção por área explorada) e das máquinas foram os principais objetivos da modernização capitalista no campo se refletindo diretamente nos níveis de produção da agropecuária. Para investigar a intensidade do uso destes recursos foram selecionadas as seguintes variáveis:

SAT1 = percentual de área trabalhada na área total dos estabelecimentos SAT2 = percentual de área com pastagens plantadas na área total com pastagens VAP1 = valor da produção agropecuária (vegetal e animal) por área explorada VAP2 = valor da produção agropecuária (vegetal e animal) por equivalentehomem

HEC1 = hectares de área explorada por trator

HEC2 = hectares de área explorada por equivalente-homem

\section{4)Relacões no mercado de trabalho}

Estudos mostram, em geral, que a modernização da agricultura tem modificado as relações de trabalho no setor. As modificações ocorridas estão relacionadas à substituição do trabalho familiar pelo assalariado, principalmente o temporário, como uma característica do próprio modelo capitalista. Entretanto, o processo de colonização do Estado de Santa Catarina, conforme descrito no item 3.1, se caracterizou pela predominância da mão-de-obra familiar em pequenas propriedades podendo fazer com que os resultados para este Estado sejam 
diferenciados do geral. Foram utilizadas três variáveis que buscaram detectar o comportamento e a composição da mão-de-obra rural catarinense:

RMT1 = percentual da mão-de-obra familiar no total de equivalente-homem RMT2 = percentual dos empregados permanentes no total de equivalente-homem RMT3 = percentual dos empregados temporários no total de equivalente-homem

Nos anos de 1975, 1980 e 1985 foram considerados como máquinas os tratores e as máquinas para plantio e colheita e como instrumentos agrícolas os arados de tração animal e tração mecânica.

\subsubsection{Medidas do grau de concentração da posse da terra}

Ao consultar a literatura referente a este tópico verificou-se que existem várias formas de medir o grau de desigualdade de uma distribuição. Estas são normalmente utilizadas nas análises de distribuição da renda, mas podem expressar, também, o grau de concentração de quaisquer outras distribuições, como o grau de concentração da posse da terra. No estudo foram utilizadas três medidas de desigualdade no cálculo da distribuição da posse da terra: o índice de Gini (GT) e a proporção da área total correspondente aos 50\% menores estabelecimentos (A50-) e aos 5\% maiores estabelecimentos (A5+), e uma medida de tendência central, a área média dos estabelecimentos (mT).

O índice de Gini e a proporção da área total pertencente aos 50\% menores estabelecimentos e aos 5\% maiores estabelecimentos são medidas diretamente associadas à curva de Lorenz. Hoffmann (1989) salienta que o índice de Gini é a melhor medida, pois é afetado por modificações ao longo de toda a curva de Lorenz, enquanto o valor dos 50- e dos 5+ corresponde a um único ponto daquela, 
e também por obedecer à condição de Pigou-Dalton, o qual estabelece que o valor de uma medida de desigualdade deve aumentar sempre que houver uma transferência regressiva, no caso da posse da terra, de terras (transferência de áreas de terra de um estabelecimento para outro que já possui mais terras). A seguir são descritas estas medidas.

\section{1) Área média dos estabelecimentos}

A área média dos estabelecimentos corresponde à divisão da área total dos estabelecimentos pelo número total de estabelecimentos existentes em cada município.

\section{2) Índice de Gini}

O índice de Gini é a medida mais comumente utilizada quando se estuda a desigualdade de uma distribuição. O seu cálculo, no caso de dados de posse da terra, parte da análise de estratos de área de terra em um sistema de eixos cartesianos ortogonais. Com o número de estabelecimentos e as suas respectivas áreas divididos em estratos e considerando a fração acumulada dos estabelecimentos, até certo estrato, representada no eixo dos $\mathrm{X}$, e a sua correspondente fração acumulada da área representada no eixo dos $\mathrm{Y}$, obtém-se uma visualização gráfica (Figura 1) da curva de Lorenz. 


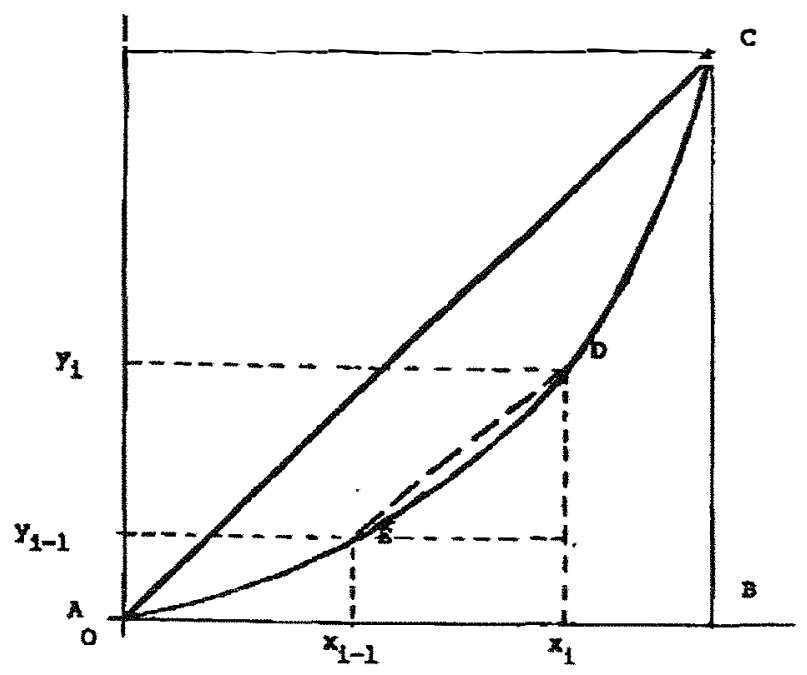

Figura 1. Curva de Lorenz

A denominada "linha de perfeita igualdade" ou "reta de equidistribuição", que parte da origem do plano cartesiano, representa o caso onde os valores de $\mathrm{Xe}$ Y são iguais (segmento $\mathrm{AC}$ ). A área entre a linha de perfeita igualdade e a curva de Lorenz é denominada de área de concentração $(\alpha)$. Por definição, a área do triângulo $\mathrm{ABC}$ é igual a 0,5 e o índice de Gini (G) que é obtido pela divisão entre a área de concentração e a área do triângulo $A B C$ é igual a $2 \alpha: G=\alpha / 0,5=2 \alpha$. Obtém-se, assim, que $0 \leq \alpha<0,5$ e $0 \leq \mathrm{G}<1$. Com os dados deste gráfico podemos obter o índice de Lorenz, que é a razão entre a área ACD e a área ACB: $\mathrm{L}=$ área $\mathrm{ACD} / \mathrm{a} r e a \mathrm{ACB}$ e o índice de Gini. O índice de Gini é obtido "aproximadamente" ao se decompor a área ACD em n trapézios. No caso da Figura 1, as medidas do trapézio são $Y_{i}$, a base maior e $Y_{i-l}$, a base menor, sendo a sua altura $\left(X_{i}-X_{i-1}\right)$. A área deste trapézio $\left(S_{i}\right)$, é assim, medida por:

$$
S_{i}=\frac{Y_{i}+Y_{i-1}}{2}\left(X_{i}-X_{i-1}\right)
$$$$
\mathrm{i}=1, \ldots, \mathrm{n}
$$ 
sendo, portanto, o índice de Gini definido por:

$$
G=1-\frac{\sum_{i=1}^{n} S_{i}}{0,5}=1-2 \sum_{i=1}^{n} S_{i}
$$

Após substituição de $S_{i}$, obtemos o índice de Gini denominado de Ge:

$$
\begin{aligned}
& G_{e}=1-\sum_{i=1}^{n}\left(Y_{i}+Y_{i-1}\right)\left(X_{i}-X_{i-1}\right) \\
& G_{e}=1-\sum_{i=1}^{n}\left(Y_{i}+Y_{i-1}\right) \pi_{h}
\end{aligned}
$$

Entretanto, verifica-se que Ge é uma medida da desigualdade entre estratos, não se incluindo na área de desigualdade as áreas compreendidas entre a curva de Lorenz e a poligonal cujos vértices são a origem dos eixos e os pontos $X_{i}$ e $Y_{i}$. Conforme Hoffmann $(1971,1979$ e 1980), isto torna o índice de Gini uma subestimativa da desigualdade real, surgindo então a necessidade de se estimar a desigualdade dentro dos estratos. É salientado pelo autor que, quando o número de estratos é bastante grande, o procedimento de cálculo descrito acima é aceitável, mas se o número de estratos é pequeno e/ou o intervalo $\pi_{h}$ correspondente a um ou mais estratos é grande, a subestimativa pode se tornar muito grande. Neste caso, é necessário calcular o índice de Gini com estimativas de desigualdade dentro dos estratos. Considerando a desigualdade dentro dos estratos $(k)$, o índice de Gini para a população $(G)$ será dado por: 


$$
G=G_{e}+\sum_{h=1}^{k} \pi_{h} Y_{h} G_{h}
$$

onde:

$G_{e}$ é o índice de Gini referente à desigualdade entre os estratos como calculado em (4) e as demais variáveis como constante em Hoffmann (1980):

$$
\pi_{h}=\frac{n_{h}}{N}
$$

é a proporção dos estabelecimentos que se situa no h-ésimo estrato;

$$
Y_{h}=\sum_{i=1}^{n_{h}} y_{h i}
$$

é a proporção da área total que está no h-ésimo estrato e $y_{h i}$ a fração da área total pertencente ao i-ésimo elemento do h-ésimo estrato;

$$
G_{h}=1-\frac{1}{n_{h}} \sum_{i=1}^{n_{h}}\left(\phi_{h i-1}+\phi_{h i}\right)
$$

é o índice de Gini referente à desigualdade dentro do h-ésimo estrato, e $\phi_{h i}$ :

$$
\phi_{h i}=\frac{1}{n_{h} \mu_{h}} \sum_{j=1}^{i} x_{h i}
$$

considerando que $x_{h i}$ é a área de cada estabelecimento; $n_{h}$ o número de estabelecimentos do h-ésimo estrato e $\mu_{h}$ a área média do h-ésimo estrato.

É bastante claro que para o cálculo de $G_{e}$ é suficiente sabermos apenas a proporção dos estabelecimentos e da área em cada estrato, mas para o cálculo de $G_{h}$ é preciso conhecer também a área de cada estabelecimento. Entretanto, os dados de área por estabelecimento não são de fácil acesso, devendo-se, então, quando estes dados não são disponíveis, buscar estimar o valor de $G_{h}$ através de outros procedimentos, como o proposto por Hoffmann (1971 e 1979), onde são 
conhecidos os limites dos estratos e se pressupõe que a distribuição dentro dos estratos com limite superior finito tem função de densidade linear e dentro dos estratos de maiores áreas, sem limite superior finito, a distribuição é a de Pareto com dois parâmetros. É importante salientar que o método indicado é utilizado apenas para se obter estimativas de desigualdade podendo levar à subestimativa ou superestimativa desta desigualdade. De acordo com Hoffmann (1979, p.727): "este método é melhor do que simplesmente ignorar as desigualdades dentro dos estratos ou admitir que a distribuição dentro de um estrato com limites finitos é necessariamente uma distribuição uniforme."

No presente estudo, para o cálculo do índice de Gini, como para a interpolação dos percentis, admitiu-se que a distribuição é a do tipo descrita, pois foram utilizados dados por estrato de área, e não por estabelecimento, constantes dos Censos. Os cálculos das medidas de posse da terra foram feitos com o auxílio do programa estatístico DESPOB-R.

Também foram considerados nas análises da estrutura fundiária os estabelecimentos de área inferior a 10 hectares, os minifúndios, chamados de estabelecimentos com "pequena área de terra", como utilizado por Figueiredo (1996), e não com o significado mais complexo estabelecido no Estatuto da Terra, que está relacionado ao conceito de módulo rural.

\subsection{Dados}

Os dados utilizados no estudo foram extraídos do Censo da Agricultura de 1920 (BRASIL, 1923, 1924, 1927 e 1930), Censo Agrícola de 1950 (IBGE, 1956), Censos Agropecuários de 1975, 1980 e 1985 (IBGE, 1979, 1983 e 1990) e de tabulações especiais do Censo Agropecuário de 1985 (dados não publicados), sendo referentes aos municípios do Estado de Santa Catarina. Entretanto, devido ao período de tempo existente entre as publicações foi necessário serem feitas 
algumas considerações quanto aos dados e conceitos utilizados nas mesmas. Foi relevante considerar a definição de um estabelecimento agropecuário.

O Censo da Agricultura de 1920 considerou que: "para fins censitários, entende-se por estabelecimento rural toda a extensão de terra sujeita à administração exclusiva de um proprietário, arrendatário, interessado, ou administrador, que faça diretamente a exploração da lavoura ou da criação, por si só ou com o auxílio de pessoal remunerado. De ordinário, o estabelecimento rural é constituído por um só lote de terras - fazenda, sítio, situação, estância, engenho, lote colonial, etc. Entretanto, pode ser às vezes representado por vários lotes, separados uns dos outros e situados num mesmo distrito ou em distritos diferentes, contanto que estejam sujeitos a uma só direção. Não devem, porém, ser considerados estabelecimentos rurais os quintais, as chácaras e os viveiros, pertencentes às casas das cidades e vilas, e bem assim os pequenos sítios da zona rural, desde que a produção deles se destine ao consumo doméstico, ou seja de pequeno valor, não constituindo verdadeiro e especial ramo de negócios" (BRASIL, 1923, p.VIII). Do Censo de 1920 foram excluídas as propriedades rurais cuja produção anual era inferior a $500 \$ 000$, sendo que apenas $37,6 \%$ da área total do total do Estado foi recenseada.

No Censo Agrícola de 1950 o conceito foi mais abrangente, sendo considerado como estabelecimento "toda exploração agropecuária constituída de área contínua, de qualquer extensão, subordinada a uma única administração. Excluiram-se as explorações exclusivamente destinadas ao consumo doméstico. Como atividade agropecuária compreenderam-se a lavoura; a criação, engorda ou guarda de gado; a criação de aves, abelhas e bicho-da-seda; o cultivo de flores e hortaliças e, ainda; a extração de produtos vegetais. Um estabelecimento pode ser constituído de terras próprias, de terras de terceiros, ou de terras próprias e de terceiros. As áreas sob a mesma administração quando não confinantes, bem 
como as explorações pertencentes a um só proprietário mas entregues a administrações diversas, foram consideradas estabelecimentos distintos. Consideram-se também estabelecimentos distintos as áreas exploradas em regime de parceria quando os responsáveis por sua administração eram os próprios parceiros. As fazendas, hortos, escolas agrícolas, postos zootécnicos, estações experimentais ou áreas semelhantes pertencentes a entidades públicas, instituições pias ou religiosas, foram investigadas apenas em relação à parte diretamente ligada à atividade agropecuária. Cada posto ou aldeamento indígena foi recenseado como um estabelecimento" (IBGE, 1956, p.XIII).

A definição de estabelecimento agropecuário, constante dos Censos Agropecuários de 1975, 1980 e 1985 é semelhante a do Censo de 1950: é "todo terreno de área contínua, independente do tamanho ou șituação (urbana ou rural), formado de uma ou mais parcelas, subordinado a um único produtor, onde se processasse uma exploração agropecuária....." (IBGE,1991,p.XIII). A importância destes conceitos é com relação aos dados utilizados na análise de posse da terra, referentes a 10 grupos de área total em 1920 e a 15 grupos de área total em 1950, 1975, 1980 e 1985 e que tem como base o número de estabelecimentos. Entretanto, pelos conceitos utilizados um estabelecimento é uma unidade de produção e não de propriedade, o que pode levar a uma superestimativa do número de estabelecimentos com relação ao número de propriedades, mas não de forma que venha a afetar significativamente as medidas de desigualdade. 


\section{RESULTADOS E DISCUSSÃO}

Os resultados e discussão estão apresentados em três períodos de tempo: 1920, 1950 e o período mais recente, 1975, 1980 e 1985. Em cada caso foram analisados a estrutura fundiária, a força de trabalho e a modernização da agricultura nos municípios catarinenses. No final do capítulo estão os resultados para todo o período analisado. Para que fosse possível uma melhor visualização das transformações ocorridas em cada período os resultados foram agregados sob a forma de percentuais de municípios em cada microrregião. A divisão do Estado vigente no período 1975, 1980 e 1985 também foi considerada em 1920 e 1950.

\subsection{Os resultados de 1920}

O primeiro ano de análise da pesquisa, 1920, ainda se situa dentro do período denominado de Primeira República. Os anos vinte, segundo Furtado (1988), abrangeram a fase áurea da economia agroexportadora que se estendeu até 1928. A economia brasileira, que tinha o café e a borracha como os principais produtos de exportação do qüinqüênio 1908-1912, representando em média 54\% e $28 \%$ do valor total das exportações brasileiras, (BRASIL, 1917), passa a 
concentrar-se exclusivamente na produção de café o que levou a uma crise de superprodução em 1929. Esta crise seguida da grande depressão precipitou a Revolução de Trinta. A participação do Estado de Santa Catarina, apesar de pequena nas exportações, ocorria através do café e de produtos menos importantes na pauta de exportações como o fumo e a erva-mate.

A produção catarinense de café, em 1920, se localizava principalmente na região de Porto Belo, na MRH de Florianópolis (297) e Blumenau, na MRH Colonial de Blumenau (294), também o maior produtor de fumo, mel, aves, leite e suínos do Estado naquele ano. A produção de erva-mate se concentrava na $\mathrm{MRH}$ de Planalto de Canoinhas (307).

A baixa participação do Estado nas exportações brasileiras ocorreu devido às limitações de natureza, principalmente climática, que não eram as mais adequadas para produzir produtos como o café. Tendo sofrido também a influência dos imigrantes europeus e dos descendentes de europeus oriundos do Rio Grande do Sul para Santa Catarina, os quais se destacaram desde o início da colonização pela produção agrícola diversificada associada a criação de animais em pequenas propriedades, (vide item 3.1), voltada para o auto-consumo e o mercado interno. A bovinocultura e ovinocultura (produção de lã) eram destaque na região de Lages. Além dos produtos mencionados, eram também produzidos no Estado, em 1920, caprinos, cana-de-açúcar, madeira, arroz, feijão, milho, mandioca, mamona, trigo, maniçoba, côco, batata e algodão.

Antes de serem apresentados os resultados da análise para este ano é preciso enfatizar que os resultados de 1920 devem ser interpretados com cautela, pois o Censo excluiu os estabelecimentos agropecuários cuja produção anual não atingia $\mathrm{Cr} \$ 500,00$. Também não foi possível analisar os minifúndios como nos demais anos, porque em 1920 os limites inferiores dos dois primeiros estratos eram zero e 41 hectares, não existindo o estrato de 10 ou menos hectares. Assim, 
os resultados apresentados devem ser interpretados levando-se em conta estas limitações dos dados.

\subsubsection{Estrutura fundiária}

Conforme os dados da Tabela 2, a concentração fundiária, medida pelo valor do índice de Gini e classificada de acordo com a escala proposta por CÂMARA $(1949)^{5}$, predominou no Estado na faixa de média e forte. Dos 34 municípios existentes, 23,6\% apresentaram concentração fundiária média, 58,8\% concentração fundiária forte e apenas $17,6 \%$, concentração fundiária muito forte. Quatro microrregiões apresentaram concentração da posse da terra muito forte: MRH de Florianópolis (297), MRH Campos de Curitibạnos (304), MRH Planalto de Canoinhas (307) e MRH Colonial do Oeste Catarinense (306), na época representada apenas pelo município de Chapecó. Nas microrregiões MRH de Campos de Lages (303) e MRH Litoral Sul Catarinense (301) todos os municípios apresentaram índice forte de concentração fundiária.

As microrregiões MRH Colonial de Blumenau (294), MRH Colonial Serrana Catarinense (298) e MRH Colonial do Rio do Peixe (305) apresentaram 100\% dos seus municípios com concentração fundiária média. Nenhum município apresentou concentração nula, fraca ou absoluta de posse da terra.

\footnotetext{
${ }^{5}$ Concentração Valor do Índice de Gini

nula zero-0.100

fraca $\quad 0,101-0,250$

média $\quad 0,251-0,500$

forte $\quad 0,501-0,700$

muito forte $\quad 0,701-0,900$

absoluta $\quad 0,901-1,000$
} 
Tabela 2. Percentual de municípios de acordo com o valor do índice de Gini e per centual de municípios com estabelecimentos de área média superior a 50 hectares, MRHs do Estado de Santa Catarina, 1920.

\begin{tabular}{|c|c|c|c|c|}
\hline \multirow[t]{2}{*}{ Microrregião } & \multicolumn{3}{|c|}{ Índice de Gini } & \multirow{2}{*}{$\begin{array}{l}\text { Area média > } \\
50 \text { hectares }\end{array}$} \\
\hline & Média & Forte & Muito forte & \\
\hline Col. de Joinville(292) & 33,3 & 66,7 & - & - \\
\hline Litoral de Itajaí(293) & 50,0 & 50,0 & - & 50,0 \\
\hline Col. de Blumenau(294) & 100,0 & - & - & 50,0 \\
\hline Col. do Itajaí do Norte(295)* & - & - & - & - \\
\hline Col. do Alto Itajaí(296)* & - & - & - & - \\
\hline Florianópolis(297) & - & 71,4 & 28,6 & 57,0 \\
\hline Col.Serrana Catarinense(298) & 100,0 & - & - & - \\
\hline Litoral de Laguna(299) & 50,0 & 50,0 & - & 100,0 \\
\hline Carbonifera(300) & 33,3 & 66,7 & - & 33,3 \\
\hline Litoral Sul Catarinense(301) & - & 100,0 & - & 50,0 \\
\hline Col.do Sul Catarinense(302)* & - & - & - & - \\
\hline Campos de Lages(303) & - & 100,0 & - & 100,0 \\
\hline Campos de Curitibanos(304) & - & 50,0 & 50,0 & 100,0 \\
\hline Col. do Rio do Peixe (305) & 100,0 & - & - & - \\
\hline Col.doOeste Catarinense(306) & - & - & 100,0 & 100,0 \\
\hline Planalto de Canoinhas(307) & - & 66,7 & 33,3 & 100,0 \\
\hline Estado de Santa Catarina & 23,6 & 58,8 & 17,6 & 62,0 \\
\hline
\end{tabular}

Fonte: Dados da pesquisa

* Microrregiões que não apresentavam municípios em 1920.

Neste ano, a área média dos estabelecimentos no Estado superava os 100 hectares e a maior parte dos municípios (62\%) apresentava estabelecimentos com área média superior a 50 hectares. As microrregiões de Litoral de Laguna (299), Campos de Lages (303), Campos de Curitibanos (304), Colonial do Oeste Catarinense (306) e Planalto de Canoinhas (307) apresentaram 100\% dos seus municípios com área média dos estabelecimentos maior do que 50 hectares, sendo 
o município de Curitibanos o que apresentou a maior área média dos estabelecimentos no Estado.

As microrregiões MRH Colonial de Joinville (292), MRH Colonial Serrana Catarinense (298) e MRH Colonial do Rio do Peixe (305) apresentaram área média dos estabelecimentos menor do que 50 hectares em todos os seus municípios.

\subsubsection{Pessoal Ocupado}

No ano de 1920 o Censo Populacional dividiu a população recenseada em homens e mulheres de zero a 20 anos, maiores de 21 anos e por profissões. Esta divisão permitiu apenas uma classificação baseada neste critério, impossibilitando análises em categorias de pessoal ocupado na agricultura (familiar, permanente, temporária, parceiros e outra condição e serviços de empreitada) como nos demais anos. A profissão predominante no Estado era a destinada à exploração do solo (agricultura, criação, caça e pesca) denominada população que exercia profissões rurais. Pode ser verificado na Tabela 3 que o pessoal ocupado era de 139.361 equivalentes-homem, estando o maior contingente (78\%) situado em regiões litorâneas, ou próximas ao Litoral e mais destacadamente na MRH Colonial de Joinville (292), MRH de Florianópolis (297), MRH Colonial de Blumenau (294) e MRH de Carbonífera (300).

Os dados disponíveis permitiram constatar que a população era composta principalmente de homens maiores de 21 anos. A mão-de-obra feminina maior de 21 anos se destacou, superando $20 \%$ do total, apenas na MRH Colonial de Joinville (292). A participação dos menores de 21 anos no total de equivalenteshomem variou de 10,4\% na MRH Colonial do Oeste Catarinense (306) a 20,5\% na MRH de Carbonífera (300). 
Tabela 3. Pessoal ocupado na agricultura, criação, caça e pesca, em equivalenteshomem, e percentual da mão-de-obra masculina e feminina, maiores de 21 anos e menores de 21 anos, MRHs do Estado de Santa Catarina, 1920.

\begin{tabular}{|c|c|c|c|c|c|}
\hline Microrregiōes & EHTOTAL ${ }^{\star}$ & $\begin{array}{c}\text { \%Masculino maior } \\
\text { de } 21 \text { anos }\end{array}$ & $\begin{array}{c}\text { \%Feminino maior } \\
\text { de } 21 \text { anos }\end{array}$ & $\begin{array}{c}\% \text { Maior } \\
\text { de } 21 \text { anos }\end{array}$ & $\begin{array}{l}\% \text { Menor } \\
\text { de } 21 \text { anos }\end{array}$ \\
\hline Col. de Joinville(292) & 17.130 & 72,6 & 27,4 & 82,9 & 17,1 \\
\hline Litoral de Itajai(293) & 7.861 & 97,3 & 2,70 & 88,7 & 11,3 \\
\hline Col. de Blumenau(294) & 20.201 & 86,0 & 14,0 & 84,0 & 16,0 \\
\hline Col. do Itajaí do Norte(295)* & - & - & - & - & - \\
\hline Col. do Alto Itajai(296)* & - & - & - & - & - \\
\hline Florianópolis(297) & 27.496 & 94,7 & 5,30 & 88,9 & 11,1 \\
\hline Col.Serrana Catarinense(298) & 1.394 & 90,7 & 9,30 & 84,5 & 15,5 \\
\hline Litoral de Laguna(299) & 8.173 & 93,8 & 6,20 & 85,3 & 14,7 \\
\hline Carbonifera(300) & 14.187 & 86,3 & 13,7 & 79,5 & 20,5 \\
\hline Litoral Sul Catarinense(301) & 9.548 & 97,9 & 2,10 & 85,3 & 14,7 \\
\hline Col. do Sul Catarinense(302)* & - & - & - & - & - \\
\hline Campos de Lages(303) & 9.730 & 97,3 & 2,70 & 88,7 & 11,3 \\
\hline Campos de Curitibanos(304) & 6.047 & 97,6 & 2,40 & 88,0 & 12,0 \\
\hline Col. do Rio do Peixe (305) & 2.854 & 92,1 & 7,87 & 89,9 & 10,1 \\
\hline Col. do Oeste Catarinense(306) & 2.401 & 96,8 & 3,20 & 89,6 & 10,4 \\
\hline Planalto de Canoinhas(307) & 12.339 & 90,3 & 9,70 & 87,6 & 12,4 \\
\hline Estado de Santa Catarina & 139.361 & 91,2 & 8,80 & 86,4 & 13,6 \\
\hline
\end{tabular}

Fonte: Dados da pesquisa EHTOTAL=total de equivalentes-homem *Não tinham municípios neste ano

\subsubsection{Modernização da agricultura}

As políticas voltadas à modernização da agricultura brasileira, apesar de terem tomado maior impulso na década de 1960, já eram evidenciadas no $1^{\circ}$ Censo da Agricultura realizado no País em 1920. As máquinas e instrumentos agrários movidos principalmente pelas forças hidráulica e a vapor e direcionadas mais especificamente às culturas da cana-de-açúcar e do café já existiam naquele 
período, apesar de representarem um reduzido valor percentual nos vários Estados da União e de se destinarem mais ao beneficiamento dos produtos agropecuários e não ao seu cultivo.

O uso de máquinas, instrumentos agrários e sementes já era considerado como um dos instrumentos de melhoramento da agricultura: "a substituição dos atuais processos de cultura pela aparelhagem agrícola é um melhoramento indispensável num País, como o Brasil, onde a falta de braços se torna cada vez mais premente. Somente a mecânica agrícola, auxiliada pelos métodos inteligentes de lavrar a terra, poderá transformar a nossa lavoura e colocá-la em condições de satisfazer as necessidades do País. Nesse sentido se tem esforçado bastante o Ministério da Agricultura, por intermédio dos campos de cooperação, isto é, as estações de lavra, devendo os fazendeiros dar o terreno e pagar aos trabalhadores, e ao governo cabendo o encargo de distribuir as sementes e fornecer os instrumentos de campo, assim como providenciar quanto ao auxílio do pessoal técnico, método prático de propaganda em prol dos melhoramentos agrários“ (BRASIL, 1927, p.V).

Já havia naquele período, 138 dos chamados campos de cooperação, de vários tipos de lavouras, em uma área de 720 hectares cultivados nos Estados brasileiros. Na distribuição dos campos de cooperação pelos 20 Estados existentes, Santa Catarina, com nove campos de cooperação, era o quarto Estado junto com o Ceará. Os Estados mais beneficiados com esta política foram o Rio de Janeiro, com 21 campos de cooperação, Minas Gerais, 19, Rio Grande do Sul e São Paulo com 12. A seguir são apresentados os resultados da análise fatorial que objetivou captar mais detalhadamente as características da agricultura catarinense em 1920.

Os resultados do processamento da matriz X (34 X 13) do ano de 1920 , constantes da Tabela 4, mostram que em 1920 foram obtidas quatro raízes 
características com valor superior a um, porém, na análise foram utilizados três fatores que representaram $73,6 \%$ da variância total, cujos valores das raizes características em ordem decrescente são: 5,$44 ; 2,82$ e 1,30. O primeiro fator captou $41,9 \%$ da variância total, o segundo $21,7 \%$ e o terceiro $10 \%$.

Tabela 4. Raízes características da matriz de correlações simples (13 X 13) para os municípios do Estado de Santa Catarina, 1920.

\begin{tabular}{cccc}
\hline FATORES & $\begin{array}{c}\text { RAIZ } \\
\text { CARACTERISTICA }\end{array}$ & \% DA VARIÂNCIA & \% ACUMULADO \\
\hline $\mathbf{1}$ & $\mathbf{5 , 4 4}$ & $\mathbf{4 1 , 8 5}$ & $\mathbf{4 1 , 8 5}$ \\
$\mathbf{2}$ & $\mathbf{2 , 8 2}$ & $\mathbf{2 1 , 7 2}$ & $\mathbf{6 3 , 5 7}$ \\
$\mathbf{3}$ & $\mathbf{1 , 3 0}$ & $\mathbf{1 0 , 0 4}$ & $\mathbf{7 3 , 6 1}$ \\
$\mathbf{4}$ & $\mathbf{1 , 0 2}$ & $\mathbf{7 , 8 7}$ & $\mathbf{8 1 , 4 8}$ \\
$\mathbf{5}$ & 0,79 & 6,12 & $\mathbf{8 7 , 6 0}$ \\
6 & 0,52 & 4,00 & 91,60 \\
$\mathbf{7}$ & 0,43 & 3,29 & 94,89 \\
$\mathbf{8}$ & 0,32 & 2,44 & 97,33 \\
9 & 0,21 & 1,60 & 98,93 \\
10 & 0,090 & 0,69 & 99,63 \\
11 & 0,035 & 0,27 & 99,90 \\
12 & 0,013 & 0,10 & 100,0 \\
13 & 0,000 & 0,00 & 100,0 \\
\hline
\end{tabular}

Fonte: Dados da pesquisa

Na Tabela 5 estão os coeficientes de correlação entre as variáveis e os fatores obtidos após a rotação ortogonal pelo método VARIMAX, constando também o valor da comunalidade e a proporção da variância de cada fator.

Em 1920 o primeiro fator (F1 1920) apresentou correlação forte e positiva com as variáveis: 
Tabela 5. Coeficiente de correlação, comunalidade de cada variável e variância explicada pelos fatores após rotação pelo método VARIMAX, municípios do Estado de Santa Catarina, 1920.

\begin{tabular}{ccccc}
\hline VARIÁVEL & FATOR 1 & FATOR 2 & FATOR 3 & COMUNALIDADE \\
\hline TEC1 & 0,0196 & $-0,118$ & $\mathbf{0 , 8 2 6}$ & 0,696 \\
TEC2 & $\mathbf{0 , 8 4 2}$ & $-0,416$ & 0,0837 & 0,888 \\
TEC3 & $-0,0133$ & $\mathbf{0 , 7 6 8}$ & 0,306 & 0,684 \\
TEC4 & $\mathbf{0 , 8 1 0}$ & $-0,288$ & 0,383 & 0,886 \\
TEC5 & 0,201 & 0,235 & $\mathbf{0 , 6 6 2}$ & 0,534 \\
CAP1 & $\mathbf{- 0 , 8 1 8}$ & $-0,453$ & $-0,220$ & 0,923 \\
CAP2 & $\mathbf{0 , 6 2 6}$ & 0,540 & 0,245 & 0,744 \\
CAP3 & $\mathbf{0 , 7 8 6}$ & 0,0926 & $-0,0510$ & 0,629 \\
SAT1 & $\mathbf{0 , 7 8 6}$ & 0,191 & $-0,0829$ & 0,661 \\
HEC1 & $-0,497$ & $-0,217$ & $-0,340$ & 0,410 \\
HEC2 & $\mathbf{- 0 , 7 5 0}$ & $-0,301$ & $-0,232$ & 0,707 \\
RMT1 & $-0,142$ & $\mathbf{0 , 9 3 7}$ & 0,0691 & 0,903 \\
RMT2 & 0,143 & $\mathbf{0 , 9 3 7}$ & $-0,0699$ & 0,903 \\
VARIÂNCIA \% & 35,0 & 25,8 & 12,8 & \\
\hline
\end{tabular}

Fonte: Dados da pesquisa

TEC2 $=$ percentual de estabelecimentos que usam a força animal

TEC4 = percentual de estabelecimentos que possuem máquinas .

CAP2 $=$ valor das benfeitorias no valor total dos bens

$\mathrm{CAP} 3$ = valor das máquinas e instrumentos agrários por área explorada

SAT 1 = percentual de área trabalhada na área total dos estabelecimentos recenseados

As correlações com as variáveis TEC2 e SAT1 indicam o uso da força animal na área trabalhada dos estabelecimentos, isto é, a exploração da terra. indicado também pela variável CAP3. O uso de máquinas em 1920 evidencia o desenvolvimento de atividades de exploração da terra como as culturas do arroz, 
café, erva-mate, açúcar, algodão e cereais em geral. Entretanto, as máquinas eram destinadas ao beneficiamento, fabricação, descaroçamento e moagem e não ao cultivo da terra. As variáveis TEC4, CAP2 e CAP3 indicam também a realização de investimentos em bens de capital. A associação negativa e elevada com as variáveis:

$\mathrm{CAP} 1=$ valor das terras no valor total dos bens

HEC2 $=$ hectares de área explorada por equivalente-homem

reforça o uso e a existência de outros bens de capital e não somente a terra, isto é, a diversificação dos investimentos em bens de capital e também a baixa intensidade no uso da força de trabalho. O fator 1 de 1920 pelas características gerais que expressa foi denominado de intensidade de exploração da terra.

O segundo fator (F2 1920) apresentou correlação forte e positiva com as variáveis:

TEC3 = número de instrumentos agrários por área explorada

RMT2 = percentual de mão-de-obra feminina no total de equivalentehomem

enquanto a correlação negativa ocorreu com a variável RMT1 (percentual de mãode-obra masculina no total de equivalente-homem). Devido as características das variáveis correlacionadas com o fator, o F2 1920 foi denominado de uso de mãode-obra feminina.

O F3 1920 se correlacionou positiva e fortemente com duas variáveis:

TEC1 = percentual de estabelecimentos que usam a força mecânica (hidraúlica e a vapor)

TEC5 = número de máquinas por equivalente-homem 
indicando o uso de máquinas e a sua associação com as forças hidraúlica e a vapor. Em 1920 eram bastante utilizadas as forças hidraúlicas e a vapor principalmente no beneficiamento do café, da cana-de-açúcar e na moagem de cereais em geral. O F3 1920 foi denominado de uso de máquinas de beneficiamento.

Apenas a variável HEC1 (hectares de área explorada por trator) apresentou uma comunalidade considerada baixa.

O Mapa 4 e a Tabela 6 mostram o número e o percentual de municípios que apresentaram valores positivos (altos e médios) para os três fatores no ano de 1920. Apenas três microrregiões apresentaram valores positivos para os três fatores simultaneamente, em pelo menos um município: MRH de Florianópolis (297), MRH Colonial Serrana Catarinense (298) e MRH de Carbonífera (300). A MRH de Florianópolis (297) apresentou valores positivos para a intensidade de exploração da terra (F1 1920), em 86\% dos seus municípios, a MRH de Carbonífera (300) em 67\% e a MRH Colonial Serrana Catarinense (298), em seu único município, Nova Trento.

Com relação ao F2 1920, uso de mão-de-obra feminina, a MRH de Florianópolis (297) apresentou valores positivos apenas em $14 \%$ dos seus municípios, a MRH de Carbonífera em 67\% e a MRH Colonial Serrana Catarinense (298) em 100\%, enquanto os valores positivos de F3 1920, uso de máquinas de beneficiamento, estavam em $71 \%$ da MRH de Florianópolis (297) em 33\% de Carbonífera (300) e em 100\% da MRH Colonial Serrana Catarinense (298). A MRH de Florianópolis (297) era a principal produtora de café do Estado e as outras duas de caprinos. 


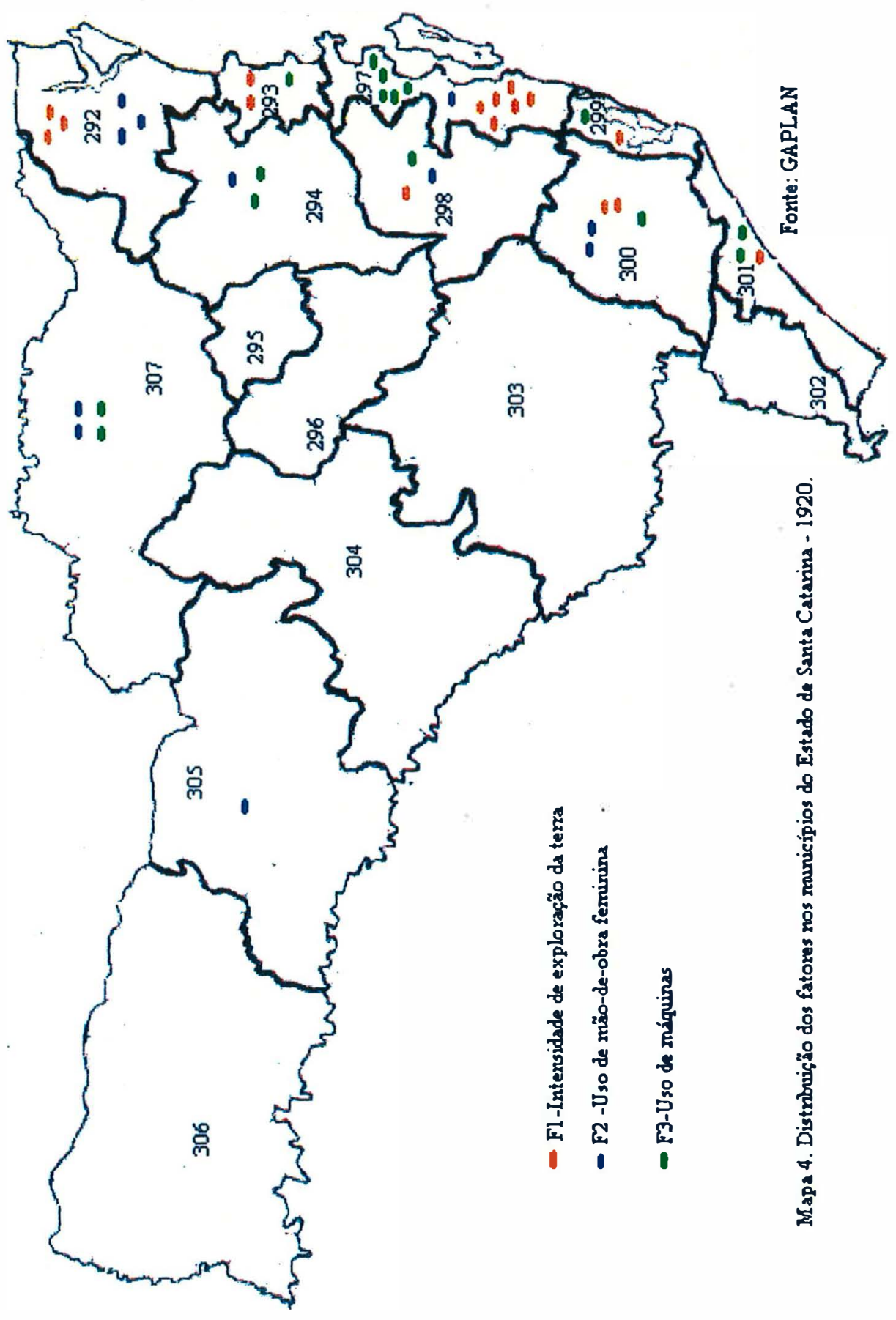


Tabela 6. Percentual de municípios que apresentaram valores positivos (altos e mé dios) para os fatores, segundo as MRHs do Estado de Santa Catarina, 1920.

\begin{tabular}{|c|c|c|c|}
\hline Microrregiāo Homogênea & $\begin{array}{c}\text { Fator } 1 \\
\text { (intensidade de } \\
\text { exploraçāo da terra) }\end{array}$ & $\begin{array}{c}\text { Fator } 2 \\
\text { (uso de māo-de-obra } \\
\text { feminina) }\end{array}$ & $\begin{array}{c}\text { Fator } 3 \\
\text { (uso de máquinas de } \\
\text { beneficiamento) }\end{array}$ \\
\hline Col. de Joinville (292) & 100,0 & 100,0 & - \\
\hline Litoral de Itajaí (293) & 100,0 & - & 50,0 \\
\hline Col. de Blumenau (294) & - & 50,0 & 100,0 \\
\hline Col. do Itajaí do Norte (295)* & - & - & - \\
\hline Col. do Alto Itajaí (296)* & - & - & - \\
\hline Florianópolis (297) & 86,0 & 14,0 & 71,0 \\
\hline Col. Serrana Catarinense (298) & 100,0 & 100,0 & 100,0 \\
\hline Litoral de Laguna (299) & 50,0 & - & 50,0 \\
\hline Carbonífera (300) & 67,0 & 67,0 & 33,0 \\
\hline Litoral Sul Catarinense (301) & 50,0 & $r$ & 100,0 \\
\hline Col. do Sul Catarinense (302)* & - & - & - \\
\hline Campos de Lages (303) & - & - & - \\
\hline Campos de Curitibanos (304) & - & - & - \\
\hline Col. do Rio do Peixe (305) & - & 100,0 & - \\
\hline Col. do Oeste Catarinense (306) & - & - & - \\
\hline Planalto de Canoinhas (307) & - & 33,0 & 33,0 \\
\hline
\end{tabular}

Fonte: Dados da pesquisa

*Microrregiões Homogêneas sem nenhum município em 1920.

A MRH Colonial de Joinville (292) apresentou valores positivos para o F1, intensidade de exploração da terra, e F2, uso de mão-de-obra feminina com instrumentos agrários, em $100 \%$ dos seus municípios. Esta microrregião produzia entre outros produtos a cana-de-açúcar, o arroz e o café.

As microrregiões MRH de Litoral de Itajaí (293), MRH Litoral de Laguna (299) e MRH Litoral do Sul Catarinense (301) apresentaram valores positivos para o F1, intensidade de exploração da terra, em respectivamente $100 \%$ e $50 \%$ dos seus municípios e valores positivos para o F3, uso de máquinas de 
beneficiamento, em 50\% e 100\% dos municípios, indicando a produção intensiva e o beneficiamento de produtos como o café, cana-de-açúcar, mandioca e arroz.

Os municípios das microrregiões MRH Colonial de Blumenau (294) e MRH Planalto de Canoinhas (307) apresentaram valores positivos para o F2 (50\% e $33 \%$, respectivamente) e o F3 (100\% e 33\%). Na região de Blumenau o destaque era a produção de leite e no Planalto de Canoinhas, a produção diversificada de milho, trigo, mel, fumo, mate e caprinos.

Na MRH Colonial do Rio do Peixe (305), com apenas um município (Cruzeiro, atual Joaçaba), somente o F2 (uso de mão-de-obra feminina) apresentou valores positivos, associado às lavouras de trigo, feijão e milho, ali predominantes no período.

Três microrregiões não apresentaram municípios neste ano: MRH Colonial do Itajaí do Norte (295), MRH Colonial do Alto do Itajaí (296) e MRH Colonial do Sul Catarinense (302) e três microrregiões apresentaram os três fatores negativos em seus municípios: MRH Campos de Lages (303), MRH Campos de Curitibanos (304) e MRH Colonial do Oeste Catarinense (306), regiões associadas principalmente à produção de ovinos e outras criações (caprinos, bovinos e eqüinos). 


\subsection{Resultados de 1950}

Trinta anos são decorridos do primeiro para o segundo ano da análise tendo o Brasil passado pelo primeiro governo de Getúlio Vargas, iniciado com a Revolução de Trinta e que se estendeu até 1945. No início dos anos Trinta, com a queda dos preços do café e o aumento dos preços dos produtos importados, o governo passa a dar ênfase na industrialização, assim introduzindo o processo de substituição de importações que levou à mudanças importantes no País. O ano de 1950, segundo da análise da agricultura catarinense, se insere no período 194664, considerado politicamente democrático.

Segundo Delgado (1997), a maior parte das políticas agrícolas e comerciais antes de 1930 tinham um caráter estadual, eram regionalizadas, sendo este quadro alterado com a crise internacional e a Revolução de 30, dando lugar à federalização das políticas de fomento e defesa dos segmentos rurais organizados. No período denominado de Estado Novo, ou ditadura de Vargas, o Governo estabelece inúmeras instituições estatais, denominadas pelos produtos rurais a que atendiam. Porém, não existiam instituições voltadas ao desenvolvimento da pecuária. Segundo o mesmo autor, a centralização das políticas agrícolas era coerente com o processo de centralização política do Estado Nacional, centralização que protegia e articulava interesses agrários regionais e setoriais.

A cultura do café que nos anos trinta havia sofrido um declínio, dando espaço ao desenvolvimento de outras culturas como a do açúcar, algodão, trigo e arroz, retorna no período de 1946-1961, denominado de pós-guerra, com um novo ciclo de valorização externa.

Em Santa Catarina, um dos principais produtos de exportação brasileiros, o café, apesar das condições climáticas adversas e da pequena participação do Estado, ainda permanece sendo produzido principalmente na MRH de 
Florianópolis (297), tendo a sua produção aumentada de 1920 para 1950 em 346\%. A cana-de-açúcar produzida principalmente nas regiões de Laguna, Joinville e Blumenau, foi o produto que apresentou o menor crescimento da produção no período (23\%).

Além do café, a produção de outras culturas sofreram acréscimos substanciais no período: arroz (305\%), milho (194\%), fumo (180\%), feijão (141\%), mandioca (143\%), lã (571\%), trigo (4166\%) e batata (144\%). Na produção animal, cresceram a produção de mel (2164\%), os rebanhos de ovinos (157\%), caprinos (179\%), bovinos (49\%), o plantel de suínos (167\%) e o de aves (82\%). Desaparecem da pauta dos principais produtos do Estado o algodão, o côco, a maniçoba e a mamona, enquanto novos produtos importantes surgem em 1950: laranja, uva, banana, maçã e cebola.

A evolução da produção agrícola e animal de 1920 para 1950 já sinalizava a importância que a produção animal viria a ter no Estado. Na década de 1950 surgem as Organizações Chapecó (1952), um dos primeiros grandes frigoríficos de suínos da região Oeste, oriundo dos pequenos matadouros que se instalaram no Estado desde o início de sua colonização e que na década de 70 , juntamente com os grupos Sadia, Cooperalfa, Perdigão e Ceval Alimentos, viria a constituir o complexo agroindustrial de aves e suínos do Estado.

\subsubsection{Estrutura fundiária}

Em 1950 todas as microrregiões passaram a apresentar municípios, o que mostra o avanço na ocupação do Estado, apesar de ter ocorrido o acréscimo de apenas 18 municípios. Conforme os dados da Tabela 7, a concentração fundiária, medida pelo valor do índice de Gini, predominou no Estado na faixa de média e forte. Neste ano, 38,5\% do total dos municípios apresentaram concentração 
fundiária média, $50 \%$ concentração fundiária forte e apenas $11,5 \%$ dos municípios apresentaram concentração muito forte.

Os municípios com os maiores valores do índice de Gini estavam localizados em quatro microrregiões: Campos de Lages (303), Campos de Curitibanos (304), Colonial do Rio do Peixe (305) e Colonial do Oeste Catarinense (306), todas localizadas no interior do Estado. Estas microrregiões juntamente com a MRH de Planalto de Canoinhas (307) foram as que apresentaram no ano de 1950 municípios com estabelecimentos de área média superior a 50 hectares.

Tabela 7. Percentual de municípios de acordo com o valor do Índice de Gini, área média superior a 50 hectares e percentual de estabelecimentos com área menor do que 10 hectares, MRHs do Estado de Santa Catarina, 1950.

\begin{tabular}{|c|c|c|c|c|c|}
\hline \multicolumn{6}{|c|}{ Índice de Gini } \\
\hline Microrregiāo & MÉDIA & FORTE & MUITO FORTE & Área $>50$ hec & Área $<10$ hec \\
\hline Col. de Joinville(292) & 40,0 & 60,0 & - & - & 27,6 \\
\hline Litoral de Itajai(293) & 50,0 & 50,0 & - & - & 24,6 \\
\hline Col. de Blumenau(294) & 66,7 & 33,3 & - & - & 21,0 \\
\hline Col. do Itajai do Norte(295) & 100,0 & - & - & - & 14,0 \\
\hline Col. do Alto Itajaí(296) & 100,0 & - & - & - & 13,7 \\
\hline Florianópolis(297) & - & 100,0 & - & - & 39,6 \\
\hline Col.Serrana Catarinense(298) & 100,0 & - & - & - & 10,1 \\
\hline Litoral de Laguna(299) & - & 100,0 & - & - & 48,4 \\
\hline Carbonifera(300) & 75,0 & 25,0 & - & - & 29,0 \\
\hline Litoral Sul Catarinense(30 1) & $=$ & 100,0 & - & - & 40,3 \\
\hline Col. do Sul Catarinense(302) & 100,0 & - & - & - & 18,4 \\
\hline Campos de Lages(303) & - & 33,3 & 66,7 & 100,0 & 9,61 \\
\hline Campos de Curitibanos(304) & - & - & 100,0 & 100,0 & 14,6 \\
\hline Col. do Rio do Peixe (305) & 57,1 & 28,6 & 14,3 & 43,0 & 11,2 \\
\hline Col. do Oeste Catarinense(306) & - & - & 100,0 & 100,0 & 13,4 \\
\hline Planalto de Canoinhas(307) & - & 100,0 & - & 100,0 & 8,58 \\
\hline Estado de Santa Catarina & 38,5 & 50,0 & 11,5 & 28,8 & 19,8 \\
\hline
\end{tabular}

Fonte: Dados da pesquisa 
As microrregiões de Florianópolis (297), Litoral de Laguna (299), Litoral Sul Catarinense (301) e Planalto de Canoinhas (307) apresentaram concentração fundiária forte em $100 \%$ de seus municípios, sendo que as três primeiras microrregiões foram as que apresentaram as maiores porcentagens de estabelecimentos com área menor do que 10 ha no Estado e a MRH Planalto de Canoinhas (307) apresentou o menor percentual de estabelecimentos menores do que 10 hectares.

As microrregiões Colonial do Itajaí do Norte (295), Colonial do Alto Itajaí (296), Colonial Serrana Catarinense (298) e Colonial do Sul Catarinense (302) apresentaram todos os seus municípios com concentração fundiária média e nenhum município apresentou estabelecimentos com área média superior a 50 hectares. Nenhum município apresentou concentração nula, fraca ou absoluta de posse da terra neste ano.

\subsubsection{Pessoal ocupado}

No ano de 1950 o Censo Agropecuário dividiu a população recenseada em categorias de pessoal ocupado: mão-de-obra familiar, permanente, temporária e de parceiros. Pode ser verificado na Tabela 8 que o pessoal ocupado era de 286.256 equivalentes-homem e estava situado principalmente na MRH Colonial do Rio do Peixe (305), seguida das MRH de Carbonífera (300) e MRH Colonial do Oeste Catarinense (306). O uso da mão-de-obra familiar era bastante expressivo em todas as microrregiões, variando de $73,7 \%$ do total na $\mathrm{MRH}$ Campos de Curitibanos (304) até 96,5\% na MRH Colonial Sul Catarinense (302). O emprego temporário superava o emprego permanente no Estado e era destaque na MRH Campos de Curitibanos (304) e MRH Planalto de Canoinhas (307). O 
emprego permanente e a parceria estavam distribuidos de uma forma mais ou menos homogênea no Estado.

Tabela 8. Composição percentual do pessoal ocupado na agricultura, MRHs do Estado de Santa Catarina, 1950.

\begin{tabular}{lccccc}
\hline Microrregiāo Homogênea & EH TOTAL50 & \%FM50 & \%EP50 & \%ET50 & \%PAR50 \\
\hline Col. de Joinville (292) & 22.356 & 93,1 & 1,72 & 3,80 & 1,36 \\
Litoral de Itajai (293) & 9.906 & 78,6 & 2,41 & 15,4 & 3,61 \\
Col. de Blumenau (294) & 19.938 & 90,4 & 3,66 & 5,16 & 0,784 \\
Col. do Itajai do Norte (295) & 4.397 & 92,7 & 1,42 & 4,39 & 1,50 \\
Col. do Alto Itajai (296) & 21.170 & 94,3 & 1,54 & 3,55 & 0,605 \\
Florianópolis (297) & 20.171 & 75,4 & 3,11 & 17,0 & 4,58 \\
Col. Serrana Catarinense (298) & 6.034 & 86,6 & 0,862 & 12,5 & 0,0275 \\
Litoral de Laguna (299) & 7.744 & 91,3 & 1,00 & 6,66 & 1,04 \\
Carbonifera (300) & 32.493 & 84,6 & 2,65 & 8,65 & 4,15 \\
Litoral Sul Catarinense (301) & 8.470 & 94,7 & 2,49 & 1,80 & 0,969 \\
Col. do Sul Catarinense (302) & 4.026 & 96,5 & 2,15 & 0,969 & 0,367 \\
Campos de Lages (303) & 15.333 & 76,9 & 3,43 & 10,0 & 9,62 \\
Campos de Curitibanos (304) & 18.169 & 73,7 & 3,43 & 22,1 & 0,815 \\
Col. do Rio do Peixe (305) & 48.221 & 89,0 & 2,07 & 6,24 & 2,67 \\
Col. do Oeste Catarinense (306) & 24.301 & 89,7 & 3,19 & 6,77 & 0,353 \\
Planalto de Canoinhas (307) & 23.527 & 75,1 & 3,79 & 19,7 & 1,41 \\
Estado de Santa Catarina & 286.256 & 85,7 & 2,56 & 9,34 & 2,40 \\
\hline
\end{tabular}

Fonte: Dados da pesquisa EHTOTAL=total de equivalentes-homem; FM=mão-de-obra familiar, $\mathrm{EP}=$ =emprego permanente; $\mathrm{ET}=$ =emprego temporário; $\mathrm{PAR}=$ parceiros

\subsubsection{Modernização da agricultura}

Segundo a literatura (Nicholls, 1975; Smith, 1983; Araújo et al., 1983; Araújo \& Meyer, 1983, entre outros) o processo de modernização da agricultura brasileira tomou maior impulso na década de 1960, especificamente a partir de 1964, e estava baseado em melhorias da infra-estrutura agrícola.

Antes deste período, de acordo com Delgado (1997, p.215): "as condições técnicas e econômicas da produção rural brasileira evoluíram muito lentamente....., só vindo a incorporar mudanças técnicas modernas praticamente dos anos cinqüenta e sessenta em diante.....a base técnica da produção sobre a qual se materializa o crescimento da agropecuária no período estava ainda fortemente ligada à tração animal, à força de trabalho residente e à abertura de 
terras novas na fronteira agrícola externa, que continuou a expandir-se durante todo o período coberto pelos Censos Agropecuários de 1940 a 1960".

Entre 1920 e 1950, apesar de não ter havido um grande aumento do número de municípios existentes, ocorreu um aumento do número, da área total dos estabelecimentos agropecuários e da força de trabalho na agricultura de Santa Catarina, refletindo a expansão da fronteira agrícola e a ocupação do seu território com um crescimento substancial da sua produção agropecuária. Os resultados da análise fatorial, apresentados a seguir, caracterizam mais detalhadamente as condições técnicas e as relações sociais de produção encontradas para 1950.

$\mathrm{Na}$ Tabela 9 estão os resultados do processamento da matriz X (52 X 19) do ano de 1950. Neste ano foram obtidas cinco raízes características com valor superior a um. Porém, na interpretação dos resultados foram utilizadas quatro raízes características, representando $70,2 \%$ da variância total, cujos valores em ordem decrescente são: 6,$40 ; 2,83 ; 2,40$ e 1,71 . O primeiro fator captou $33,7 \%$ da variância total, o segundo $14,9 \%$, o terceiro $12,6 \%$ e o quarto $9 \%$.

Da Tabela 10 constam os coeficientes de correlação entre as variáveis e os fatores obtidos após a rotação ortogonal pelo método VARIMAX, o valor da comunalidade e a proporção da variância de cada fator.

Em 1950, o primeiro fator (F1 1950) apresentou correlações positivas e elevadas com as variáveis:

SAT1 = percentual da área trabalhada na área total dos estabelecimentos

SAT2 $=$ percentual de área com pastagens plantadas na área total com pastagens

RMT1=percentual de mão-de-obra familiar no total de equivalente-homem que refletem a intensidade de exploração da terra associada ao uso de mão-deobra familiar e pastagens plantadas. As correlações fortes e negativas do fator 1 foram com as variáveis: 
Tabela 9. Raízes características da matriz de correlações $(19 \times 19)$ para os municípios do Estado de Santa Catarina, 1950.

\begin{tabular}{cccc}
\hline FATORES & RAIZ & \% DA VARIÂNCIA & \% ACUMULADO \\
& CARACTERISTICA & & \\
\hline $\mathbf{1}$ & $\mathbf{6 , 4 0}$ & $\mathbf{3 3 , 6 8}$ & $\mathbf{3 3 , 6 8}$ \\
$\mathbf{2}$ & $\mathbf{2 , 8 3}$ & $\mathbf{1 4 , 8 9}$ & $\mathbf{4 8 , 5 7}$ \\
$\mathbf{3}$ & $\mathbf{2 , 4 0}$ & $\mathbf{1 2 , 6 4}$ & $\mathbf{6 1 , 2 1}$ \\
$\mathbf{4}$ & $\mathbf{1 , 7 1}$ & $\mathbf{9 , 0 0}$ & $\mathbf{7 0 , 2 1}$ \\
$\mathbf{5}$ & $\mathbf{1 , 3 8}$ & $\mathbf{7 , 2 8}$ & $\mathbf{7 7 , 4 8}$ \\
6 & 0,92 & 4,82 & $\mathbf{8 2 , 3 0}$ \\
7 & 0,82 & 4,31 & 86,61 \\
8 & 0,59 & 3,14 & 89,75 \\
9 & 0,49 & 2,61 & 92,35 \\
10 & 0,34 & 1,80 & 94,15 \\
11 & 0,31 & 1,63 & 95,78 \\
12 & 0,24 & 1,26 & 97,04 \\
13 & 0,17 & 0,89 & 97,93 \\
14 & 0,13 & 0,68 & 98,60 \\
15 & 0,10 & 0,55 & 99,15 \\
16 & 0,075 & 0,39 & 99,54 \\
17 & 0,045 & 0,24 & 99,78 \\
18 & 0,036 & 0,19 & 99,97 \\
19 & 0,0053 & 0,03 & 100,0 \\
\hline
\end{tabular}

Fonte: Dados da pesquisa

TEC7 $=$ percentual de estabelecimentos que usam veículos de carga a motor

RMT2 = percentual da mão-de-obra permanente no total de equivalentehomem

RMT3 = percentual da mão-de-obra temporária no total de equivalentehomem 
também indicam que o fator 1 representa o uso de mão-de-obra familiar. O F1 1950 foi denominado de intensidade de exploração da terra associado ao uso de mão-de-obra familiar e pastagens plantadas.

Tabela 10. Coeficiente de correlação, comunalidade de cada variável e variância explicada pelos fatores após rotação pelo método VARIMAX, municípios do Estado de Santa Catarina, 1950.

\begin{tabular}{|c|c|c|c|c|c|}
\hline VARIAVEL & FATOR 1 & FATOR 2 & FATOR 3 & FATOR 4 & COMUNALIDADE \\
\hline TECI & $-0,214$ & 0,157 & 0,794 & $-0,115$ & 0,714 \\
\hline TEC2 & 0,447 & 0,214 & 0,726 & 0,229 & 0,825 \\
\hline TEC3 & $-0,0290$ & 0,246 & $-0,129$ & 0,806 & 0,727 \\
\hline TEC4 & 0,0462 & 0,0945 & 0,420 & 0,605 & 0,553 \\
\hline TEC5 & 0,00161 & 0,169 & 0,868 & $-0,136$ & 0,800 \\
\hline TEC6 & 0,0576 & 0,618 & 0,301 & 0,102 & 0,487 \\
\hline TEC7 & $-0,730$ & $-0,0608$ & 0,287 & $-0,125$ & 0,635 \\
\hline TEC8 & 0,228 & 0,0505 & 0,817 & - 0,0957 & 0,732 \\
\hline TEC9 & $-0,0780$ & 0,0211 & $-0,0978$ & 0,846 & 0,731 \\
\hline CAPI & $-0,260$ & $-0,915$ & $-0,0728$ & $-0,115$ & 0,923 \\
\hline CAP2 & 0,346 & 0,800 & 0,102 & 0,0256 & 0,771 \\
\hline CAP3 & 0,554 & 0,219 & 0,365 & 0,397 & 0,646 \\
\hline CAP4 & $-0,0725$ & 0,886 & 0,0756 & 0,0674 & 0,801 \\
\hline SAT1 & 0,630 & 0,273 & 0,374 & 0,161 & 0,637 \\
\hline SAT2 & 0,760 & 0,160 & 0,0849 & 0,139 & 0,630 \\
\hline $\mathrm{HECl}$ & $-0,557$ & $-0,655$ & $-0,151$ & 0,257 & 0,828 \\
\hline RMTI & 0,797 & 0,149 & 0,0935 & $-0,239$ & 0,723 \\
\hline RMT2 & $-0,648$ & $-0,0608$ & 0,106 & 0,344 & 0,554 \\
\hline RMT3 & $-0,760$ & $-0,0538$ & $-0,175$ & 0,100 & 0,622 \\
\hline VARIÂNCIA \% & 22,4 & 18,0 & 17,5 & 12,2 & \\
\hline
\end{tabular}

Fonte: Dados da pesquisa

O segundo fator (F2 1950) apresentou correlações fortes e positivas com as variáveis:

TEC6 = percentual de estabelecimentos que usam veículos de carga (tração animal)

CAP2 $=$ valor das benfeitorias no valor total dos bens 
CAP4 $=$ valor dos veículos e animais de trabalho no valor total dos bens

indicando a realização de investimentos em outros bens de capital, além da terra. As correlações negativas com as variáveis:

CAP1 $=$ valor das terras no valor total dos bens

$\mathrm{HECl}=$ hectares de área explorada por equivalente-homem

reforçam a importância dos investimentos em bens de capital que não a terra e indicam baixa intensidade no uso da mão-de-obra com relação à terra. O F2 1950 foi denominado de investimentos em bens de capital.

O F3 1950 se associou positiva e fortemente com as variáveis:

$\mathrm{TEC} 1=$ percentual de estabelecimentos que usam a força animal

TEC2 = número de instrumentos agrários por área explorada

TEC5 = número de instrumentos agrários por equivalente-homem

TEC8 = número de arados de tração animal por área explorada que formam um conjunto relacionado ao uso da força animal, já que todas as variáveis se referem ao uso da mesma. Em 1950, o uso da força mecânica era inexpressivo no Estado, sendo os instrumentos agrários expressos pelas variáveis TEC2 e TEC5 basicamente movidos a força animal. O F3 1950 foi denominado de uso de tração animal.

A associação forte e positiva do $\mathrm{F} 41950$ com as variáveis:

TEC3 = valor das despesas com adubos e fertilizantes por área explorada

TEC4 $=$ valor das despesas com inseticidas e fungicidas por área explorada

TEC9 = número de tratores por área explorada

indica o uso de insumos modernos. Sendo assim, o F4 1950 foi chamado de uso de insumos modernos. 
O Mapa 5 mostra o número de municípios com valores altos e médios para cada fator de modernização e a Tabela 11, o percentual destes municípios para 0 ano de 1950. Pode ser verificado que quatro microrregiões apresentaram valores positivos para os quatro fatores simultaneamente, em pelo menos um município: MRH Colonial do Rio do Peixe (305), MRH Colonial de Joinville (292), MRH Colonial de Blumenau (294) e MRH de Carbonífera (300). As duas primeiras apresentaram valores positivos para o F1 1950, que reflete a intensidade de exploração da terra com o uso de mão-de-obra familiar e pastagens plantadas, em respectivamente $43 \%$ e $60 \%$ dos seus municípios e as duas últimas, em 100\%.

As microrregiões Colonial de Joinville (292), Colonial de Blumenau (294), Colonial do Rio do Peixe (305) e Carbonífera (300) apresentaram respectivamente $100 \%, 83 \%, 43 \%$ e $25 \%$ dos seus municípios com valores positivos para o F2 1950, investimentos em bens de capital.

As microrregiões Colonial do Rio do Peixe (305), Colonial de Joinville (292), Colonial de Blumenau (294) e Carbonífera (300) apresentaram valores positivos para $\mathrm{F} 3$, uso de tração animal, em $100 \%, 60 \%$, 50\% e $25 \%$ dos seus municípios enquanto os valores positivos do $\mathrm{F} 4$, uso de insumos modernos, estavam em $43 \%, 40 \%, 50 \%$ e $25 \%$ dos municípios.

Estas quatro microrregiões eram as mais importantes do Estado em termos de produção agropecuária no ano de 1950. A MRH Colonial de Joinville (292) era a maior produtora de banana e arroz do Estado; a MRH de Carbonífera (300) apresentava as maiores produções de citrus (laranja e tangerina), cana-de-açúcar, mandioca e cebola; a MRH Colonial de Blumenau (294) apresentava o maior plantel de aves e as maiores produções de leite, ovos, aipim e fumo e a $\mathrm{MRH}$ Colonial do Rio do Peixe (305) possuia o maior plantel de suínos e a maior produção de uva, batata, feijão, milho e trigo do Estado. 


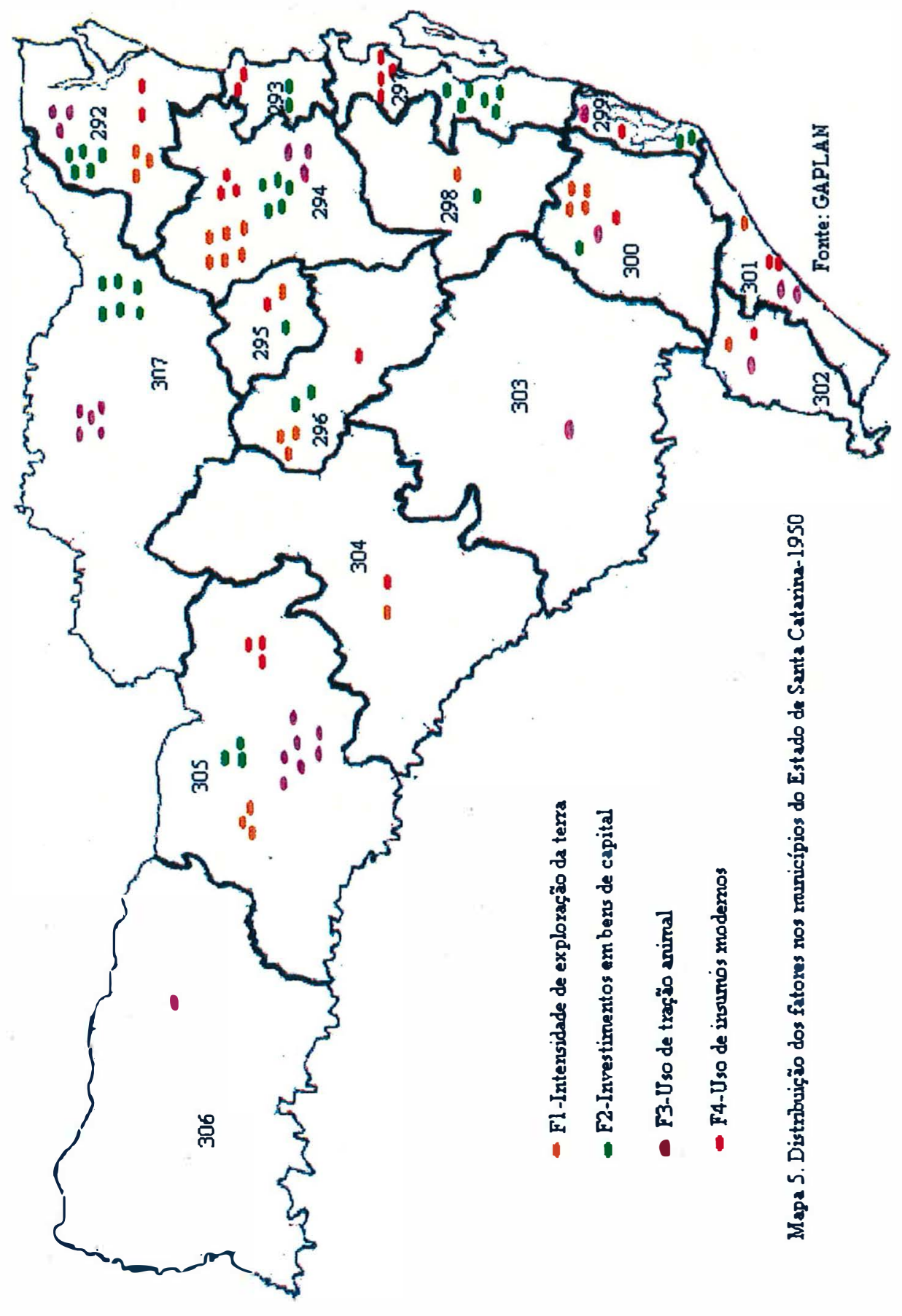


Tabela 11. Percentual de municípios que apresentaram valores positivos (altos e médios) para os fatores, segundo as MRH do Estado de Santa Catarina, 1950.

\begin{tabular}{|c|c|c|c|c|}
\hline Microrregião Homogênea & $\begin{array}{c}\text { Fator } 1 \\
\text { (intensidade de } \\
\text { exploração da } \\
\text { terra) }\end{array}$ & $\begin{array}{c}\text { Fator } 2 \\
\text { (investimentos } \\
\text { em bens de } \\
\text { capital) }\end{array}$ & $\begin{array}{c}\text { Fator } 3 \\
\text { (uso de tração } \\
\text { animal) }\end{array}$ & $\begin{array}{c}\text { Fator } 4 \\
\text { (uso de } \\
\text { insumos } \\
\text { modernos) }\end{array}$ \\
\hline Col. de Joinville (292) & 60,0 & 100,0 & 60,0 & 40,0 \\
\hline Litoral de Itajai (293) & - & 100,0 & - & 100,0 \\
\hline Col. de Blumenau (294) & 100,0 & 83,0 & 50,0 & 50,0 \\
\hline Col. do Itajaí do Norte (295) & 100,0 & 100,0 & - & 100,0 \\
\hline Col. do Alto Itajaí (296) & 100,0 & 67,0 & - & 33,0 \\
\hline Florianópolis (297) & - & 100,0 & - & 67,0 \\
\hline Col. Serrana Catarinense (298) & 100,0 & 100,0 & - & - \\
\hline Litoral de Laguna (299) & - & 100,0 & 50,0 & 50,0 \\
\hline Carbonifera (300) & 100,0 & 25,0 & 25,0 & 25,0 \\
\hline Litoral Sul Catarinense (301) & 50,0 & - & 100,0 & 100,0 \\
\hline Col. do Sul Catarinense (302) & 100,0 & - & 100,0 & 100,0 \\
\hline Campos de Lages (303) & - & - & 33,0 & - \\
\hline Campos de Curitibanos (304) & 50,0 & - & - & 50,0 \\
\hline Col. do Rio do Peixe (305) & 43,0 & 43,0 & 100,0 & 43,0 \\
\hline Col. do Oeste Catarinense (306) & - & - & 100,0 & . \\
\hline Planalto de Canoinhas (307) & - & 100,0 & 83,0 & - \\
\hline
\end{tabular}

Fonte: Dados da pesquisa

Nas microrregiões Colonial do Itajaí do Norte (295) e Colonial do Alto Itajaí (296) todos os municípios apresentaram valores positivos para o F1, intensidade de exploração da terra, F2, investimentos em bens de capital (100\% e $67 \%$ respectivamente) e $\mathrm{F} 4$, uso de insumos modernos $(100 \%$ e $33 \%$ respectivamente). Estas regiões eram produtoras principalmente de fumo neste ano. 
As microrregiões Litoral de Itajaí (293) e Florianópolis (297) apresentaram valores positivos para $\mathrm{F} 2$, investimentos em bens de capital, em $100 \%$ dos seus municípios e $\mathrm{F} 4$, uso de insumos modernos, em respectivamente $100 \%$ e $67 \%$ dos seus municípios. Os principais produtos destas microrregiões em 1950 eram a cana-de-açúcar e o café, nas MRH 293 e 297, respectivamente.

A MRH Colonial Serrana Catarinense (298) se caracterizou pela identificação de seu único município, Nova Trento, produtor de café, com F1, intensidade de exploração da terra e o F2, investimentos em bens de capital.

A MRH Litoral de Laguna (299) apresentou valores positivos para F2, investimentos em bens de capital (100\% dos municípios), F3, uso de tração animal e F4, uso de insumos modernos, em 50\% dos seus municípios. Esta microrregião estava, na época, associada às culturas de mandioca, cana-de-açúcar e arroz.

A MRH Campos de Lages (303) e a MRH Colonial do Oeste Catarinense (306) apresentaram somente o $\mathrm{F} 3$ positivo, em respectivamente $33 \%$ e $100 \%$ dos seus municípios. A MRH Campos de Lages (303) apresentava os maiores rebanhos de bovinos, ovinos, eqǘnos, caprinos, a maior produção de maçã e madeira do Estado e a MRH Colonial do Oeste Catarinense (306), que em 1950 era composta apenas do município de Chapecó, cultivava principalmente fumo, trigo e milho.

A MRH Campos de Curitibanos (304) apresentou valores positivos para F1, intensidade de exploração da terra, e F4, uso de insumos modernos, em metade de seus municípios e já se destacava no período como produtora de maçã. 
A MRH Planalto de Canoinhas (307) apresentou valores positivos para o F2, investimentos em bens de capital, e F3, uso de tração animal. Esta região é caracterizada pela grande diversificação da produção agropecuária (maçã, fumo, trigo, batata, lã, caprinos, equinos, mate e colméias).

As microrregiões MRH Litoral Sul Catarinense (301) e a MRH Colonial Sul Catarinense (302) apresentaram valores positivos para o F1, intensidade de exploração da terra, em $50 \%$ e $100 \%$ dos municípios, respectivamente, e para F3, uso de tração animal e F4, uso de insumos modernos, em 100\% dos seus municípios.

\subsection{Resultados do período 1975, 1980 e 1985}

O último período da análise, 1975-1985, envolve politicamente o regime militar iniciado em 1964 e que teve seu fim em 1985. O modelo de substituição de importações continuou a orientar as políticas do governo militar, sendo observados também, com mais intensidade, os efeitos das políticas sobre a concentração de renda em todos os setores da economia. Neste período o café já não é mais o principal produto de exportação brasileiro, cedendo lugar a produtos como a soja e a laranja, cuja produção também foi estimulada em Santa Catarina.

As políticas estiveram voltadas para a diversificação da pauta de exportações, o que conduziu ao crescimento gradativo da importância dos produtos industrializados que vieram a superar o valor das exportações dos produtos básicos tradicionais. A soja e o alho passam a ser incluídos como um dos principais produtos produzidos no Estado de Santa Catarina, respectivamente em 1975 e 1980. 
O principal instrumento de política agrícola, de 1964 até meados da década de 80 , foi o crédito rural subsidiado vinculado às grandes propriedades, sendo que em Santa Catarina os estímulos do crédito foram destinados principalmente às agroindústrias de aves e suínos. Em 1970, o grupo Sadia implanta no Oeste catarinense o sistema de integração para produzir aves através da parceria com os produtores, o qual foi posteriormente utilizado pelas demais empresas ali instaladas na década de 70 , não só para a produção de aves, mas também de suínos.

A região Oeste constituída pelas MRH Colonial do Oeste Catarinense e MRH Colonial do Rio do Peixe passa a ser considerada o "celeiro catarinense", devido à grande quantidade de grãos produzidos, sendo a principal produtora de feijão, milho, soja, trigo, batata, mandioca, bovinos de leite, suínos e aves do Estado, representando mais de 50\% do Valor Bruto da Produção Agropecuária catarinense.

No período 1980-1985 o Estado representava cerca de 4\% do total das exportações brasileiras, com os produtos agroindustriais como os principais componentes da sua pauta de exportações (produtos do complexo soja, carne de frango e fumo), destacando-se a Ceval Agroindustrial como $0 \cdots$ principal exportador do complexo soja.

\subsubsection{Estrutura fundiária em 1975, 1980 e 1985}

No período entre 1950 e 1975 ocorreu uma alteração significativa no número de municípios existentes em Santa Catarina, que passou de 52 para 197. Com os resultados relativos ao percentual de municípios catarinenses de acordo com o valor do índice de Gini nos anos de 1975, 1980 e 1985, contidos na Tabela 12 , pode ser verificado que a concentração fundiária predominou no Estado nos 
três anos na faixa de média e forte, sendo que nenhum município apresentou uma concentração absoluta da posse da terra, o mesmo acontecendo para as concentrações nula ou fraca.

Tabela 12. Percentual de municípios de acordo com o valor do índice de Gini, MRHs do Estado de Santa Catarina, 1975, 1980 e 1985.

\begin{tabular}{|c|c|c|c|c|c|c|c|c|c|}
\hline & & 1975 & & & 1980 & & & 1985 & \\
\hline Microrregiāo & MEDIA & FORTE & $\begin{array}{l}\text { MUITO } \\
\text { FORTE }\end{array}$ & MEDIA & FORTE & $\begin{array}{l}\text { MUITO } \\
\text { FORTE }\end{array}$ & MÉDIA & FORTE & MUITO \\
\hline Col. de Joinville(292) & 44,4 & 44,4 & 11,1 & 22,2 & 33,3 & 44,4 & 22,2 & 44,4 & 33,3 \\
\hline Litoral de Itajai(293) & 12,5 & 87,5 & - & 25,0 & 75,0 & - & - & 87,5 & 12,5 \\
\hline Col. de Blumenau(294) & 37,5 & 62,5 & - & 25,0 & 62,5 & 12,5 & 37,5 & 56,3 & 6,25 \\
\hline Col. do Itajai do Norte(295) & 100,0 & - & - & 75,0 & 25,0 & - & 75,0 & 25,0 & - \\
\hline Col. do Alto Itajai(296) & 62,5 & 37,5 & - & 68,8 & 25,0 & 6,25 & 62,5 & 37,5 & - \\
\hline Florianópolis(297) & - & 60,0 & 40,0 & - & 30,0 & 70,0 & 10,0 & 20,0 & 70,0 \\
\hline Col.Serrana Catarinense(298) & 41,7 & 58,3 & - & 16,7 & 75,0 & 8,33 & 16,7 & 66,7 & 16,7 \\
\hline Litoral de Laguna(299) & - & 100,0 & - & - & 33,3 & 66,7 & - & 33,3 & 66,7 \\
\hline Carbonifera(300) & 70,6 & 29,4 & - & 76,5 & 17,6 & 5,88 & 82,4 & 11,8 & 5,88 \\
\hline Litoral Sul Catannense(301) & 16,7 & 83,3 & - & - & 100,0 & - & 16,7 & $83,3 \ldots$ & - \\
\hline Col.do Sul Catarinense(302) & 50,0 & 50,0 & - & 16,7 & 83,3 & - & 33,3 & 66,7 & - \\
\hline Campos de Lages(303) & - & 40,0 & 60,0 & - & 40,0 & 60,0 & - & 42,9 & 57,1 \\
\hline Campos de Curitibanos(304) & - & 37,5 & 62,5 & - & 25,0 & 75,0 & - & 37,5 & 62,5 \\
\hline Col. do Rio do Peixe (305) & 70,0 & 13,3 & 16,7 & 66,7 & 13,3 & 20,0 & 66,7 & 13,3 & 20,0 \\
\hline Col.doOeste Catarinense(306) & 73,5 & 17,6 & 8,82 & 70,6 & 20,6 & 8,82 & 67,6 & 29,4 & 2,94 \\
\hline Planalto de Canoinhas(307) & - & 61,5 & 38,5 & - & 53,8 & 46,2 & - & 46,2 & 53,8 \\
\hline Estado de Santa Catarina & 46,7 & 40,1 & 13,2 & 41,6 & 37,1 & 21,3 & 42,2 & 37,7 & 20,1 \\
\hline
\end{tabular}

Fonte: Dados da pesquisa 
Em 1975, sete microrregiões apresentaram municípios com concentração muito forte da posse da terra aumentando em 1980 e 1985 para 12 microrregiões. As microrregiões que apresentaram os maiores percentuais de municípios na classificação de concentração muito forte, em 1975, foram a MRH Campos de Lages (303), MRH Campos de Curitibanos (304), MRH de Florianópolis (297) e MRH Planalto de Canoinhas (307). Em 1985 permanecem estas microrregiões, sendo incluída a MRH Litoral de Laguna (299), que em 1975 apresentou 100\% dos seus municípios com forte concentração fundiária e que em 1985 destacou-se com concentração fundiária muito forte em $66,7 \%$ dos seus municípios.

$\mathrm{Na}$ Tabela 13 encontra-se o percentual de municípios catarinenses com estabelecimentos de área média superior a 50 hectares. No período de 1975-1985, o maior percentual de municípios com estabelecimentos de área média superior a 50 hectares estavam localizados na MRH Campos de Lages (303), 100\% dos municípios, na MRH Campos de Curitibanos (304), 75\% dos municípios, seguidas da MRH Planalto de Canoinhas (307) que apresentou 46,2\% dos municípios. Na MRH Colonial do Oeste Catarinense (306) apenas o município de Abelardo Luz, representando 2,94\% do total, apresentou estabelecimentos com uma área média superior a 50 hectares.

A MRH Colonial Serrana Catarinense (298) e a MRH Colonial do Rio do Peixe (305) apresentaram em 1975, 16,7\% dos municípios, decrescendo este percentual em 1985, para 8,33\% dos municípios apenas na MRH Colonial Serrana Catarinense (298). A MRH de Carbonífera (300) apresentou apenas $5,88 \%$ dos seus municípios com estabelecimentos de área acima de 50 hectares no período.

Em 1975 eram nove microrregiões localizadas em toda a extensão do Litoral e no Vale do Itajaí, que não apresentavam municípios com estabelecimentos de área média acima de 50 hectares, diminuindo para sete 
microrregiões nos anos de 1980 e 1985, sendo as principais alterações ocorridas nas MRH Colonial de Joinville (292) e MRH de Florianópolis (297) que passaram a apresentar municípios com área média superior a 50 hectares. Na MRH Litoral de Itajaí (293) o percentual de municípios (12,5\%) só aparece em 1980.

Tabela 13. Percentual de municípios com estabelecimentos de área média superior a 50 hectares, MRHs do Estado de Santa Catarina, 1975, 1980 e 1985.

\begin{tabular}{|c|c|c|c|}
\hline Microrregião & 1975 & 1980 & 1985 \\
\hline Col. de Joinville $(292)$ & - & 33,3 & 33,3 \\
\hline Litoral de Itajai(293) & - & 12,5 & - \\
\hline Col. de Blumenau(294) & - & - & - \\
\hline Col. do Itajai do Norte(295) & - & - & - \\
\hline Col. do Alto Itajai(296) & - & - & - \\
\hline Florianópolis(297) & - & - & 10,0 \\
\hline Col.Serrana Catarinense(298) & 16,7 & 8,33 & 8,33 \\
\hline Litoral de Laguna(299) & - & - & - \\
\hline Carbonifera(300) & 5,88 & 5,88 & 5,88 \\
\hline Litoral Sul Catarinense(30l) & - & - & - \\
\hline Col.do Sul Catarinense(302) & - & - & - \\
\hline Campos de Lages(303) & 100,0 & 100,0 & 100,0 \\
\hline Campos de Curitibanos(304) & 75,0 & 75,0 & $75 ; 0$ \\
\hline Col. do Rio do Peixe (305) & 16,7 & 16,7 & 16,7 \\
\hline Col.do Oeste Catarinense(306) & 2,94 & 5,88 & 2,94 \\
\hline Planalto de Canoinhas(307) & 46,2 & 53,8 & 46,2 \\
\hline Estado de Santa Catarina & 13,2 & 15,7 & 15,6 \\
\hline
\end{tabular}

Fonte: Dados da pesquisa

Na Tabela 14 está o percentual de estabelecimentos com área inferior a 10 hectares nas microrregiões catarinenses nos anos de 1975, 1980 e 1985. Pode ser verificado que no Estado de Santa Catarina, de uma forma geral, o número de minifúndios evoluiu de $33,9 \%$ em 1975 para $35,1 \%$ em 1980 e $39,1 \%$ em 1985 . A 
MRH Litoral de Laguna (299) apresentou nos três anos o maior percentual de estabelecimentos com área inferior a 10 hectares, mas de uma forma decrescente, $75,5 \%$ em 1975, 74,1\% em 1980 e $72 \%$ em 1985, seguida da MRH de Florianópolis (297) com 61,4\% em 1975, 60,2\% em 1980 e 51,6\% em 1985. A MRH Litoral de Itajaí (293) apresentou um comportamento oscilante do número de minifúndios, de 41,8\% em 1975 passou a 32,3\% em 1980 e 34\% em 1985 devido ao desenvolvimento da cultura canavieira.

Tabela 14. Percentual de estabelecimentos com área inferior a 10 hectares, MRH do Estado de Santa Catarina, 1975, 1980 e 1985.

\begin{tabular}{|c|c|c|c|}
\hline Microrregião & 1975 & 1980 & 1985 \\
\hline Col. de Joinville(292) & 32,9 & 37,8 & 40,0 \\
\hline Litoral de Itajai(293) & 41,8 & 32,3 ， & 34,0 \\
\hline Col. de Blumenau(294) & 41,3 & 40,8 & 44,6 \\
\hline Col. do Itajaí do Norte(295) & 21,8 & 18,4 & 25,4 \\
\hline Col. do Alto Itajai(296) & 29,9 & 31,7 & 37,1 \\
\hline Florianópolis(297) & 61,4 & 60,2 & 51,6 \\
\hline Col.Serrana Catarinense(298) & 29,7 & 30,2 & 36,5 \\
\hline Litoral de Laguna(299) & 75,5 & 74,1 & 72,0 \\
\hline Carbonifera(300) & 32,7 & 32,8 & 39,7 \\
\hline Litoral Sul Catarinense(301) & 48,7 & 48,9 & 57,5 \\
\hline Col.do Sul Catarinense(302) & 37,0 & 37,5 & 40,9 \\
\hline Campos de Lages(303) & 16,5 & 16,0 & 24,4 \\
\hline Campos de Curitibanos(304) & 27,3 & 26,9 & 34,0 \\
\hline Col. do Rio do Peixe (305) & 20,8 & 22,0 & 26,3 \\
\hline Col.do Oeste Catarinense(306) & 37,7 & 40,7 & 45,0 \\
\hline Planalto de Canoinhas(307) & 27,4 & 29,7 & 30,7 \\
\hline Estado de Santa Catarina & 33,9 & 35,1 & 39,1 \\
\hline
\end{tabular}

Fonte: Dados da pesquisa

As microrregiões Colonial do Rio do Peixe (305), Colonial do Oeste Catarinense (306) e Planalto de Canoinhas (307) apresentaram um aumento 
contínuo no número de estabelecimentos com área inferior a 10 hectares, mas ficando em um percentual inferior a $50 \%$ dos estabelecimentos existentes. A MRH de Campos de Lages (303) foi a que apresentou menor número de minifúndios no Estado nos três anos. As microrregiões Colonial de Blumenau (294), Colonial do Itajaí do Norte (295), Colonial Serrana Catarinense (298), Campos de Curitibanos (304) apresentaram um comportamento oscilante. As demais microrregiões mostraram o mesmo comportamento verificado para 0 Estado de uma forma geral.

Na tabela 15 está o percentual de municípios que apresentou aumento do número total de estabelecimentos, aumento da área média e aumento do valor do índice de Gini no período 1975-1985. No Estado, de uma forma geral, 140 municípios $(71,1 \%$ do total) apresentaram aumento no número total de estabelecimentos e apenas 64 municípios (33\% do total) aumento de área média, enquanto 131 municípios $(66,5 \%$ do total) apresentaram aumento do índice de Gini.

Se por um lado houve, na maior parte do Estado, um aumento do número de estabelecimentos, por outro lado, pode ser verificado que nas microrregiões Colonial de Joinville (292), Litoral de Itajaí (293), Colonial de Blumenau (294), Colonial do Itajaí do Norte (295), Florianópolis (297) e Litoral de Laguna (299), localizadas ao Norte e no Litoral do Estado, um percentual expressivo de municípios apresentou redução no número total de estabelecimentos.

Enquanto os municípios que apresentaram estabelecimentos com aumento de área média estavam localizados principalmente nas microrregiões homogêneas Colonial de Joinville (292), Litoral de Itajaí (293), Florianópolis (297) e Litoral de Laguna (299), regiões litorâneas ligadas à cultura da cana-de-açúcar para fins industriais que se utilizam de produção própria e que levaram à diminuição do número de pequenas propriedades e ao êxodo rural, os municípios que 
apresentaram redução de área média, 67\% no Estado, estavam localizados com destaque na MRH Campos de Lages (303) onde 100\% dos municípios apresentaram diminuição da área média, associada com o processo migratório e a instalação de japoneses em grandes propriedades desmembradas do Planalto Catarinense. Na MRH Campos de Lages (303) se situa o município de Lages que possuia a maior área total do Estado desde 1920 a 1982.

Tabela 15. Percentual de municípios que apresentaram aumento do número de estabelecimentos, aumento da área média e aumento do valor do índice de Gini no período 1975-1985, MRHs do Estado de Santa Catarina.

\begin{tabular}{|c|c|c|c|}
\hline Microrregião & $\begin{array}{c}\text { Número de } \\
\text { estabelecimentos }\end{array}$ & Área média & Índice de Gini \\
\hline Col. de Joinville (292) & 44,4 & 100,0 , & $\mathbf{8 8 , 9}$ \\
\hline Litoral de Itajai(293) & 25,0 & 100,0 & 87,5 \\
\hline Col. de Blumenau(294) & 37,5 & 50,0 & 68,8 \\
\hline Col. do Itajai do Norte(295) & 25,0 & 25,0 & 75,0 \\
\hline Col. do Alto Itajai(296) & 93,8 & 25,0 & 56,3 \\
\hline Florianópolis(297) & 30,0 & 80,0 & 80,0 \\
\hline Col.Serrana Catarinense(298) & 58,3 & 25,0 & 58,3 \\
\hline Litoral de Laguna(299) & 33,3 & 100,0 & 100,0 \\
\hline Carbonifera $(300)$ & 88,2 & 5,88 & 64,7 \\
\hline Litoral Sul Catarinense(301) & 66,7 & 16,7 & 66,7 \\
\hline Col.do Sul Catarinense(302) & 83,3 & 33,3 & 50,0 \\
\hline Campos de Lages(303) & 80,0 & - & 40,0 \\
\hline Campos de Curitibanos(304) & 87,5 & 25,0 & 62,5 \\
\hline Col. do Rio do Peixe (305) & 83,3 & 20,0 & 70,0 \\
\hline Col.do Oeste Catarinense(306) & 94,1 & 8,82 & 61,8 \\
\hline Planalto de Canoinhas(307) & 69,2 & 46,2 & 61,5 \\
\hline Estado de Santa Catarina & 71,1 & 33,0 & 66,5 \\
\hline
\end{tabular}

Fonte: Dados da pesquisa

Os valores do índice de Gini aumentaram na maior parte dos municípios de todas as microrregiões, indicando aumento da concentração fundiária com exceção da MRH de Campos de Lages (303), onde 40\% dos municípios apresentaram aumento deste índice. 


\subsubsection{Pessoal ocupado em 1975, 1980 e 1985}

Na Tabela 16 estão os resultados relativos ao total de pessoal ocupado na agricultura, em equivalentes-homem, e a sua composição percentual no período 1975-1985. Pode ser constatado que o total da força de trabalho ocupada na agricultura do Estado cresceu no período, passando de 622.774 equivalenteshomem em 1975 para 689.516 em 1985. Entre 1975-1985, o maior número de equivalentes-homem ocupados na agricultura estava situado na MRH Colonial do Oeste Catarinense (306).

Houve no período um aumento do pessoal ocupado na agricultura, principalmente nas microrregiões Colonial do Oeste Catarinense (306), Colonial do Rio do Peixe (305), Planalto de Canoinhas (307), Campos de Lages (303) e Campos de Curitibanos (304). Isto devido ao crescimento das agroindústrias de cames no Oeste e ao movimento migratório de japoneses para o Planalto. Nas microrregiões Colonial do Alto Itajaí (296), Colonial Serrana Catarinense (298) e Carbonífera (300), também houve aumento do pessoal ocupado.

Por outro lado, houve a diminuição do pessoal ocupado nas microrregiões Colonial de Joinville (292), Litoral de Itajaí (293), Colonial de Blumenau (294), Colonial do Itajaí do Norte (295), Florianópolis (297), Litoral de Laguna (299), Litoral do Sul Catarinense (301) e Colonial do Sul Catarinense (302), devido ao crescimento das indústrias urbanas próximas à zona rural e especificamente em microrregiões do Litoral, devido ao desenvolvimento da agroindústria canavieira que ao se utilizar de produção própria, provocou a diminuição do número de pequenas propriedades e o êxodo rural. Isto é, a industrialização urbana e rural provocou mudanças nas relações sociais de produç̧ão de todo o Estado ao provocar o êxodo. 
Tabela 16. Composição percentual do pessoal ocupado na agricultura, MRHs do Estado de Santa Catarina, período1975-1985.

\begin{tabular}{|c|c|c|c|c|c|c|}
\hline Microrregiāo Homogênea & EHTOTAL & $\% \mathrm{FM}$ & $\%$ EP & $\%$ ET & $\%$ PAROC & \%EMPR \\
\hline \multicolumn{7}{|l|}{1975} \\
\hline Col. de Joinville (292) & 21.320 & 88,7 & 3,95 & 2,89 & 0,575 & 3,90 \\
\hline Litoral de Itajai (293) & 5.436 & 83,8 & 11,5 & 1,91 & 0,349 & 2,44 \\
\hline Col. de Blumenau (294) & 48.635 & 95,3 & 2,12 & 1,63 & 0,242 & 0,695 \\
\hline Col. do Itajai do Norte (295) & 15.178 & 96,4 & 1,09 & 1,76 & 0,0635 & 0,739 \\
\hline Col. do Alto Itajai (296) & 43.438 & 95,6 & 1,35 & 1,61 & 0,312 & 1,16 \\
\hline Florianópol is (297) & 15.972 & 92,1 & 3,70 & 1,58 & 0,327 & 2,33 \\
\hline Col. Serrana Catarinense (298) & 24.999 & 95,7 & 1,17 & 2,07 & 0,253 & 0,819 \\
\hline Litoral de Laguna (299) & 12.975 & 94,8 & 1,01 & 3,43 & 0,351 & 0,453 \\
\hline Carbonifera (300) & 42.694 & 94,3 & 1,71 & 2,17 & 0,906 & 0,862 \\
\hline Litoral Sul Catarinense (301) & 23.327 & 90,3 & 1,76 & 5,33 & 0,967 & 1,67 \\
\hline Col. do Sul Catarinense (302) & 21.734 & 90,0 & 1,31 & 4,47 & 2,11 & 2,09 \\
\hline Campos de Lages (303) & 23.823 & 75,1 & 11,9 & 4,44 & 2,06 & 6,47 \\
\hline Campos de Curitibanos (304) & 36.895 & 81,7 & 6,57 & 7,03 & 0,549 & 4,11 \\
\hline Col. do Rio do Peixe (305) & 78.088 & 90,6 & 5,03 & 1,80 & 0,399 & 2,10 \\
\hline $\begin{array}{c}\text { Col. do Oeste Catarinense } \\
(306)\end{array}$ & 165.223 & 93,7 & 1,61 & 1,99 & 0,787 & 1,96 \\
\hline Planalto de Canoinhas (307) & 43.037 & 82,2 & 5,59 & 9,34 & 0,424 & 2,41 \\
\hline Estado de Santa Catarina & 622.774 & 91,0 & 3,20 & 3,09 & 0,662 & 2,04 \\
\hline \multicolumn{7}{|l|}{1985} \\
\hline Col. de Joinville (292) & 19.917 & 83,2 & 7,89 & 3,89 & 1,06 & 3,97 \\
\hline Litoral de Itajai (293) & 4.336 & 67,2 & 22,3 & 4,92 & 0,935 & 4,60 \\
\hline Col. de Blumenau (294) & 42.443 & 90,4 & 3,94 & 2,37 & 1,07 & 2,18 \\
\hline Col. do Itajai do Norte (295) & 13.335 & 91,3 & 4,53 & 2,68 & 0,882 & 0,587 \\
\hline Col. do Alto Itajai (296) & 47.192 & 89,1 & 4,01 & 4,51 & 0,791 & 1,61 \\
\hline Florianópolis (297) & 11.776 & 77,3 & 15,6 & 3,72 & 1,16 & 2,27 \\
\hline Col. Serrana Catarinense (298) & 25.016 & 91,9 & 3,10 & 3,26 & 1,06 & 0,664 \\
\hline Litoral de Laguna (299) & 9.791 & 87,8 & 3,72 & 6,92 & 0,492 & 1,09 \\
\hline Carbonifera (300) & 45.623 & 89,5 & 3,96 & 3,84 & 1,76 & 0,961 \\
\hline Litoral Sul Catarinense (301) & 23.156 & 82,6 & 5,75 & 9,30 & 0,936 & 1,41 \\
\hline Col. do Sul Catarinense (302) & 20.707 & 86,8 & 4,00 & 6,19 & 1,01 & 2,05 \\
\hline Campos de Lages (303) & 29.357 & 66,7 & 14,8 & 13,1 & 1,56 & 3,84 \\
\hline Campos de Curitibanos (304) & 48.723 & 64,9 & 9,03 & 20,7 & 2,02 & 3,29 \\
\hline Col. do Rio do Peixe (305) & 89.699 & 82,9 & 8,14 & 5,18 & 1,46 & 2,36 \\
\hline $\begin{array}{c}\text { Col. do Oeste Catarinense } \\
(306)\end{array}$ & 204.012 & 89,0 & 3,64 & 5,02 & 0,820 & 1,52 \\
\hline Planalto de Canoinhas (307) & 54.434 & 77,7 & 7,69 & 9,68 & 1,37 & 3,55 \\
\hline Estado de Santa Catarina & 689.516 & 84,1 & 5,99 & 6,63 & 1,17 & 2,08 \\
\hline
\end{tabular}

Fonte: Dados da pesquisa

EHTOTAl=equivalente-homem total; $\mathrm{FM}=$ =mão-de-obra familiar; $\mathrm{EP}=$ =mprego permanente; $E T=e m p r e g o$ temporário; $P A R O C=$ parceiros e outra condição; $E M P R=$ serviços de empreitada

No período 1975-1985, pode ser verificado que houve diminuição da participação da mão-de-obra familiar seguida do aumento da participação do emprego permanente e temporário em todas as microrregiões. A diminuição da 
mão-de-obra familiar foi mais destacada na MRH Litoral de Itajaí (293), MRH Campos de Lages (303) e MRH Campos de Curitibanos (304) e o aumento do emprego permanente nas microrregiões Litoral de Itajaí (293) e Florianópolis (297), enquanto a participação do emprego temporário aumentou destacadamente nas microrregiões de Campos de Lages (303) e Campos de Curitibanos (304).

Todo este processo envolvendo a mão-de-obra familiar, permanente e temporária, ocorreu com maior destaque nas regiões litorâneas pela diminuição do número de pequenas propriedades na cultura canavieira e no Planalto pela culturas do alho e da maçã que se utilizam de mão-de-obra assalariada temporária.

As categorias de parceiros/outra condição e serviços de empreitada, que foram as menos representativas no contexto da mão-de-obra rural, não apresentaram o mesmo comportamento nas microrregiões como nas categorias de mão-de-obra familiar, permanente e temporária. A categoria de serviços de empreitada diminuiu a sua participação em nove microrregiões (MRH 295, MRH 297, MRH 298, MRH 301, MRH 302, MRH 303, MRH 304, MRH 306 e MRH 307) e aumentou nas restantes, indicando uma tendência de diminuição no uso de serviços de terceiros na contratação de mão-de-obra, enquanto a categoria de parceiros/outra condição diminuiu apenas em três microrregiões (MRH 301, MRH 302 e MRH 303) aumentando nas demais.

\subsubsection{Modernização da agricultura}

As políticas agrícolas que foram adotadas na década de 1960, com o objetivo de estimular o processo de modernização da agricultura brasileira, em busca dos aumentos de produtividade, estavam voltadas mais à modernização da estrutura de produção do que à alterações na estrutura fundiária. As melhorias ocorridas foram atribuídas, principalmente, aos empréstimos subvencionados para 
a aquisição de insumos modernos como adubos, fertilizantes, defensivos químicos, sementes melhoradas e máquinas, formando um conjunto que visava a exploração do excedente agrícola exportável cujos retornos destinavam-se ao financiamento do setor industrial.

A transferência de retornos para o setor industrial ocorria através de um sistema de taxas de câmbio múltiplas, que discriminavam as exportações tradicionais e favoreciam a importação de equipamentos industriais e bens de produção, isto é, uma política voltada a explorar a agricultura para financiar o desenvolvimento do setor industrial em detrimento do desenvolvimento e do bemestar rural.

Especialmente no período 1969/1976, os benefícios do crédito subsidiado, através de taxas de juros reais negativas, foram destinados às propriedades que possivelmente apresentariam mais rápidos aumentos de produção, ou seja, às grandes propriedades e aos produtos com possibilidades de industrialização e/ou exportação, sendo as regiões Sul e Sudeste, particularmente os Estados de São Paulo, Paraná, Rio Grande do Sul e Minas Gerais os mais beneficiados (Molinar, 1984; Delgado, 1985). Cabe ressaltar que o Estado de Santa Catarina, apesar de pertencer à região Sul, devido às suas características fundiárias, não foi um dos Estados que mais crédito recebeu neste período (vide Anuário do Crédito). Os maiores incentivos para o Estado, na década de 1970, foram para as agroindústrias ali instaladas, com destaque para os setores de aves e suínos.

A introdução de variedades melhoradas de sementes, exigentes em insumos modernos, importados e de alto custo, resultou também em benefícios para as propriedades de maior tamanho, marginalizando, e não raras vezes, forçando, pequenos produtores a abandonar a atividade. As políticas tecnológicas e econômicas que favoreceram a expansão da indústria nacional de tratores, fertilizantes e defensivos também levaram às disparidades regionais da 
modernização (Santos, 1986). Com o destino de maiores recursos ao Centro-Sul e Oeste originaram-se diferenças regionais de produtividade e renda agrícola, com ganhos maiores nas regiões Sul e Sudeste, principalmente no Estado de São Paulo. O grande desenvolvimento do setor agrícola paulista foi analisado por autores como Schuh (1975), como sendo relacionado, além das políticas, ao modelo de impacto urbano-industrial desenvolvido por Schultz (1953).

De uma forma geral, segundo Barros et al. (1977), Alves \& Pastore (1980), Landim \& Monteiro (1991), entre outros, as políticas de modernização da agricultura brasileira, em termos de modelos e teorias, tiveram basicamente a influência do modelo de inovações induzidas de Hayami \& Ruttan (1971). Porém, alguns autores contestaram este modelo como sendo o apropriado na explicação da modernização da agricultura brasileira. Schuh (1975), por exemplo, argumenta que este modelo é mais útil para explicar a falta de modernização da agricultura brasileira, já que havia uma dotação de fatores imprópria à mudança técnica e políticas econômicas que amorteciam os incentivos de preços.

Também para Santos (1986) o modelo de inovações induzidas não se aplica ao processo de modernização pois, no período 1950-1982, não foi identificada nenhuma relação entre variação de preços relativos de fatores e mudança técnica na agricultura brasileira. Observou-se neste período viéses de mudança técnica, principalmente de terra, trabalho e de usuários de máquinas e outros insumos. Em sua argumentação contra o modelo de inovações induzidas Santos (1988) acrescenta que foram as políticas econômicas beneficiando o setor industrial e a disponibilidade de pacotes tecnológicos importados, que determinaram a aceleração do processo de modernização da agricultura a partir da década de 1960. O incentivo ao uso da tecnologia, segundo o autor, não teria considerado a dotação natural dos fatores.

Porém, a maior parte da literatura sugere que foi baseado no modelo de 
inovações induzidas que ocorreu a evolução da produção agrícola, principalmente através da expansão da fronteira agrícola, pela existência de abundância de terra e trabalho. Entretanto, com a escassez destes fatores na região Centro-Sul criaramse as condições para o aumento da produtividade agrícola, através da pesquisa pública e o desenvolvimento de inovações tecnológicas. A criação da Empresa Brasileira de Pesquisa Agropecuária (EMBRAPA) em 1973, segundo Pastore \& Alves (1975), ilustra uma política de desenvolvimento tecnológico adotada pelo governo que também teria tido a influência, além do modelo de inovações induzidas, do modelo de insumos modernos de Schultz (1964).

Entretanto, o uso de inovações tecnológicas na agricultura brasileira resultou em prejuízos econômicos e sociais a uma parcela de agricultores. Exemplos destes resultados negativos são o dualismo tecnológico e o êxodo rural, geradores de pobreza nas margens das cidades, explicados por Paiva (1975), através do mecanismo de auto-controle, ou os problemas de degradação dos recursos naturais e concentração de renda, citados por Vergara Filho (1993), entre outros. Além do êxodo rural foram consideradas por Silva et al. (1983), como manifestações típicas do desenvolvimento capitalista no campo e conseqüência do aumento do ritmo do processo de modernização da agricultura, a aceleração da concentração fundiária e a proletarização dos trabalhadores rurais.

A participação do Estado neste contexto foi como agente financiador da modernização da agricultura, principalmente através do sistema de crédito rural subsidiado, que por um lado estimulou a modernização e, por outro lado, foi considerado o elemento central para explicar as desigualdades na modernização: "(....)aquelas regiões, produtos e produtores que não tiveram acesso ao crédito ou o tiveram em grau insuficiente estão de antemão excluídos do processo de modernização agrícola ou no mínimo não podem compensar seu atraso relativo em comparação com aqueles mais aquinhoados pelos beneficios do crédito farto e 
barato" (Hoffmann et al., 1985, p.16). Também fica evidente que o Estado, ao direcionar as políticas modernizantes, deu pouca atenção a certos fatores estruturais como: "educação rural deficiente, pesquisa e extensão ineficazes e, talvez, a estrutura de posse da terra" (Smith, 1983, p.214).

Mas, nas atuais décadas, as políticas de concessão de crédito não perduraram nos moldes iniciais. As constantes pressões com relação ao crédito, beneficiando os grandes produtores, fizeram com que fossem introduzidas restrições para afastar os maiores produtores e beneficiar os pequenos (Alves, 1993). Por volta da década de 1980 , não havendo recursos para atender a todos, o crédito restringiu-se aos pequenos agricultores e ao Nordeste. De 1985 a 1990 ampliou-se o programa de irrigação de forma a poupar a fronteira agrícola. De 1990 em diante não se deu continuidade a este programa. A partir de 1985 diminuiu de uma forma geral o crédito para investimento e o crédito para custeio passou a ser praticado à taxas de juros elevadas. O crédito rural deixou então de ser considerado um instrumento de modemização da agricultura.

Na década de 80, segundo Rezende \& Goldin (1993), a intervenção do Estado esteve centrada na política de preços mínimos e na contração do crédito rural e dos gastos públicos com pesquisa e extensão. Não somente a crise fiscal do Estado contribuiu para o perfil das políticas agrícolas adotadas no País. O persistente descontrole inflacionário, que foi objeto dos sucessivos planos econômicos de estabilização adotados a partir de 1986, contribuiram para o quadro econômico e político geral. Destaca Lamounier (1994) que na segunda metade da década de 80, a política agrícola do País assume gradativamente um papel regulatório orientado pela existência dos recursos limitados. Aqui novamente predominaram as medidas de adoção de políticas de curto prazo, visando então o controle da inflação e o equilíbrio das contas públicas, as quais 
priorizaram novamente o setor de mercado (urbano-industrial) em detrimento do desenvolvimento do setor agrícola.

O consenso geral evidencia que o modelo de política agrícola adotado no País até a primeira metade da década de 1980 foi um dos responsáveis pela concentração de renda brasileira, entre outros resultados negativos. Dados do Banco Mundial referentes aos anos de 1988/1989 colocavam o Brasil como sendo o País que apresentava maior desigualdade social e de renda do mundo, fato que persiste no período recente de 1994-1997, que envolve o Plano Real, apesar de ter havido um crescimento do consumo nas classes mais pobres. A seguir são apresentados os resultados da análise fatorial realizada para melhor captar as características da agricultura catarinense no período 1975-1985.

\subsubsection{Resultados de 1975}

Os resultados do processamento da matriz X $(197 \times 22)$ do ano de 1975 , constantes da Tabela 17, mostram que em 1975 foram obtidas quatro raízes características com valores superior a um, representando $70,2 \%$ da variância total, cujos valores em ordem decrescente são: 6,$94 ; 4,0 ; 2,93$ e 1,57 , sendo que o primeiro fator captou $31,6 \%$ da variância total, o segundo $18,2 \%$, o terceiro $13,3 \%$ e o quarto $7,14 \%$. Na interpretação dos resultados foram utilizados estes fatores que explicam grande parte da variância total das 22 variáveis do estudo.

$\mathrm{Na}$ Tabela 18 estão os coeficientes de correlação entre as variáveis e os fatores obtidos após a rotação ortogonal pelo método VARIMAX. São apresentados também o valor da comunalidade e a proporção da variância que cada fator representa. 
Tabela 17. Raízes características da matriz de correlações $(22 \times 22)$ para os municípios do Estado de Santa Catarina, 1975.

\begin{tabular}{|c|c|c|c|}
\hline FATORES & $\begin{array}{c}\text { RAIZ } \\
\text { CARACTERISTICA }\end{array}$ & \% DA VARIÂNCIA & $\%$ ACUMULADO \\
\hline 1 & 6,94 & 31,55 & 31,55 \\
\hline 2 & 4,00 & 18,19 & 49,74 \\
\hline 3 & 2,93 & 13,33 & 63,07 \\
\hline 4 & 1,57 & 7,14 & 70,21 \\
\hline 5 & 0,91 & 4,13 & 74,33 \\
\hline 6 & 0,81 & 3,67 & 78,00 \\
\hline 7 & 0,78 & 3,54 & 81,55 \\
\hline 8 & 0,70 & 3,20 & 84,74 \\
\hline 9 & 0,64 & 2,92 & 87,67 \\
\hline 10 & 0,49 & 2,24 & 89,91 \\
\hline 11 & 0,45 & 2,04 & 91,95 \\
\hline 12 & 0,41 & 1,88 & 93,83 \\
\hline 13 & 0,29 & 1,32 & 95,15 \\
\hline 14 & 0,25 & 1,13 & 96,28 \\
\hline 15 & 0,19 & 0,88 & 97,16 \\
\hline 16 & 0,18 & 0,84 & 97,99 \\
\hline 17 & 0,14 & 0,66 & 98,65 \\
\hline 18 & 0,11 & 0,52 & 99,17 \\
\hline 19 & 0,090 & 0,41 & 99,58 \\
\hline 20 & 0,041 & 0,19 & 99,77 \\
\hline 21 & 0,031 & 0,14 & 99,91 \\
\hline 22 & 0,020 & 0,09 & 100,0 \\
\hline
\end{tabular}

Fonte: Dados da pesquisa

Em 1975, o primeiro fator (F1 1975) apresentou correlação forte e positiva com as variáveis:

TEC2 $=$ percentual de estabelecimentos que usam a força animal

TEC7 = número de arados de tração animal por área explorada

CAP5 = valor das máquinas e instrumentos agrários por área explorada 
Tabela 18. Coeficiente de correlação, comunalidade de cada variável e variância explicada pelos fatores após rotação pelo método VARIMAX, municípios do Estado de Santa Catarina, 1975.

\begin{tabular}{|c|c|c|c|c|c|}
\hline VARIAVEL & FATOR 1 & FATOR 2 & FATOR 3 & FATOR 4 & COMUNALIDADE \\
\hline TECl & 0,0210 & $-0,130$ & 0,644 & 0,283 & 0,512 \\
\hline TEC2 & 0,758 & 0,286 & 0,0410 & $-0,154$ & 0,682 \\
\hline TEC3 & 0,163 & 0,145 & 0,731 & 0,0911 & 0,590 \\
\hline TEC4 & 0,478 & 0,154 & 0,115 & 0,678 & 0,725 \\
\hline TEC5 & $-0,0584$ & $-0,0933$ & 0,860 & 0,0310 & 0,752 \\
\hline TEC6 & 0,120 & 0,901 & $-0,0836$ & $-0,0151$ & 0,833 \\
\hline TEC7 & 0,763 & 0,326 & $-0,0679$ & $-0,367$ & 0,827 \\
\hline TEC8 & $-0,102$ & 0,0161 & 0,826 & $-0,141$ & 0,712 \\
\hline CAP1 & 0,518 & 0,684 & 0,249 & 0,0821 & 0,806 \\
\hline CAP2 & 0,533 & 0,714 & 0,0820 & $-0,0878$ & 0,809 \\
\hline CAP3 & 0,113 & 0,556 & 0,0710 & 0,648 & 0,747 \\
\hline CAP4 & 0,247 & $-0,0612$ & $-0,441$ & $-0,137$ & 0,278 \\
\hline CAP5 & 0,729 & 0,409 & 0,253 & 0,0194 & 0,763 \\
\hline SAT1 & 0,910 & 0,177 & $-0,0737$ & $-0,0287$ & 0,865 \\
\hline SAT2 & 0,741 & 0,0137 & $-0,360$ & $-0,0842$ & 0,687 \\
\hline VAPl & 0,356 & 0,793 & 0,123 & $-0,261$ & 0,838 \\
\hline VAP2 & 0,0711 & 0,837 & $-0,0110$ & 0,253 & 0,769 \\
\hline $\mathrm{HECl}$ & $-0,172$ & $-0,209$ & $-0,645$ & 0,0342 & 0,491 \\
\hline $\mathrm{HEC} 2$ & $-0,566$ & $-0,145$ & $-0,337$ & 0,499 & 0,703 \\
\hline RMT1 & 0,307 & 0,0402 & $-0,0912$ & $-0,903$ & 0,919 \\
\hline RMT2 & $-0,300$ & 0,105 & $-0,0177$ & 0,774 & 0,701 \\
\hline RMT3 & $-0,130$ & $-0,246$ & 0,293 & 0,524 & 0,438 \\
\hline VARLÂNCIA \% & 21,2 & 18,3 & 15,9 & 14,8 & \\
\hline
\end{tabular}

Fonte: Dados da pesquisa

SAT1 $=$ percentual de área trabalhada na área total dos estabelecimentos

SAT2 $=$ percentual de área com pastagens plantadas na área total com pastagens

refletindo a intensidade de exploração da terra (variáveis TEC7, CAP5, SAT1 e SAT2) associada principalmente ao uso da força animal (variáveis TEC2 e TEC7) 
e também ao uso de máquinas, já que existe uma correlação positiva entre o fator e o valor dos bens em máquinas e instrumentos agrários (variável CAP5). A variável SAT2 (percentagem de área com pastagens plantadas na área total com pastagens) indica também o uso intensivo da terra na plantação de pastagens. Pelo conjunto de variáveis associadas, o fator 1 em 1975 foi denominado de intensidade de exploração da terra com tração animal associada às pastagens plantadas. O segundo fator (F2 1975) apresentou correlação forte e positiva com as variáveis :

TEC6 = valor das despesas com medicamentos e alimentos por unidadeanimal

CAP1 $=$ valor dos financiamentos por área explorada

CAP2 = valor dos investimentos por área explorada

VAP1 = valor da produção agropecuária por área explorada

VAP2 = valor da produção agropecuária por equivalente-homem

o que expressa o uso de capital financeiro de terceiros (pelos financiamentos) relacionados ao curto prazo (despesas com medicamentos e alimentos por unidade-animal) e longo prazo (valor dos investimentos por área explorada) e intensidade no uso da terra e do trabalho (VAP1 e VAP2). Este conjunto de variáveis reflete modernização, já que o uso de crédito expresso pelo fator foi uma das premissas deste processo, correspondendo também a realidade catarinense onde o rebanho de aves, suínos e gado (leiteiro e de corte) é expressivo e detectável pelas despesas com medicamentos e alimentos por unidade-animal. O F2 1975 foi denominado, então de uso de capital de terceiros, de curto e longo prazo, relacionado à produção a nimal.

Com o terceiro fator (F3 1975) as correlações fortes e positivas ocorreram com as variáveis:

TEC1 = percentual de estabelecimentos que usam a força mecânica 
TEC3 = valor das despesas com adubos e corretivos por área explorada

TEC5 $=$ valor das despesas com defensivos agrícolas por área explorada

TEC8 = número de tratores por área explorada

o que reflete o uso de insumos modernos (variáveis TEC1, TEC3, TEC5 e TEC8). A correlação forte e negativa com a variável HEC 1 (hectares de área explorada por trator) é coerente com o conjunto, pois ao aumentar o número de tratores por área explorada diminuem os hectares de área explorada por trator. O F3 1975 expressa o uso de insumos modernos.

O quarto fator (F4 1975) apresentou correlação elevada e positiva com as variáveis:

TEC4 $=$ valor das despesas com sementes e mudas por área explorada

$\mathrm{CAP} 3=$ valor dos financiamentos por equivalente-homem

RMT2 = percentual dos empregados permanentes no total de equivalentehomem

correlação forte e negativa com a variável RMT1 (percentual da mão-de-obra familiar no total de equivalente-homem) expressando o uso de mão-de-obra assalariada associada ao uso de crédito (variável CAP3) e também às atividades de curto prazo, como o plantio, identificada pelas despesas com sementes e mudas por área explorada. O uso de mão-de-obra assalariada é bastante representativo do que foi conceituado como modernização. O F4 1975 foi chamado de uso de mãoobra-assalariada.

No conjunto, apenas três variáveis apresentaram uma comunalidade considerada baixa:

CAP4 $=$ valor dos animais no valor total dos bens

$\mathrm{HECl}=$ hectares de área explorada por trator

RMT3 = percentual dos empregados temporários no total de equivalentehomem 
Entretanto, estas variáveis foram mantidas por serem importantes nas análises dos anos de 1980 e 1985.

O Mapa 6 mostra o número e a Tabela 19 o percentual de municípios que apresentaram valores positivos (altos e médios) para os quatro fatores em 1975. Cinco microrregiões apresentaram valores positivos para os quatro fatores simultaneamente, em pelo menos um município: MRH Colonial do Alto Itajaí (296), MRH Litoral do Sul Catarinense (301), MRH Colonial do Rio do Peixe (305), MRH Colonial do Oeste Catarinense (306) e MRH Planalto de Canoinhas (307).

A MRH Colonial do Oeste Catarinense (306) apresentou valores positivos para a intensidade de exploração da terra, F1 1975, em 94,1\% dos seus municípios, enquanto na MRH Litoral do Sul Catarinense (301) este percentual foi de 50\%, na MRH Colonial do Rio do Peixe (305) 46,7\%, na MRH Planalto de Canoinhas (307) $15,4 \%$ e na MRH Colonial do Alto Itajaí (296) apenas $12,5 \%$.

Com relação ao uso de capital financeiro de terceiros relacionado à produção animal, o F2 1975, a MRH Colonial do Rio do Peixe (305) apresentou valores positivos em 56,7\% dos municípios, a MRH Colonial do Oeste Catarinense (306) em 23,5\%, a MRH Litoral do Sul Catarinense (301) 16,7\%, a MRH Planalto de Canoinhas (307) 15,4\% e a MRH Colonial do Alto Itajaí (296) apenas $6,25 \%$.

O percentual de municípios que apresentou valores positivos para o uso de insumos modernos (F3 1975) foi considerado médio nas microrregiões $\mathrm{MRH}$ Colonial do Rio do Peixe (305), MRH Colonial do Oeste Catarinense (306) e MRH Planalto de Canoinhas (307) com respectivamente 20\%, 32,4\% e 38,5\% municípios. 


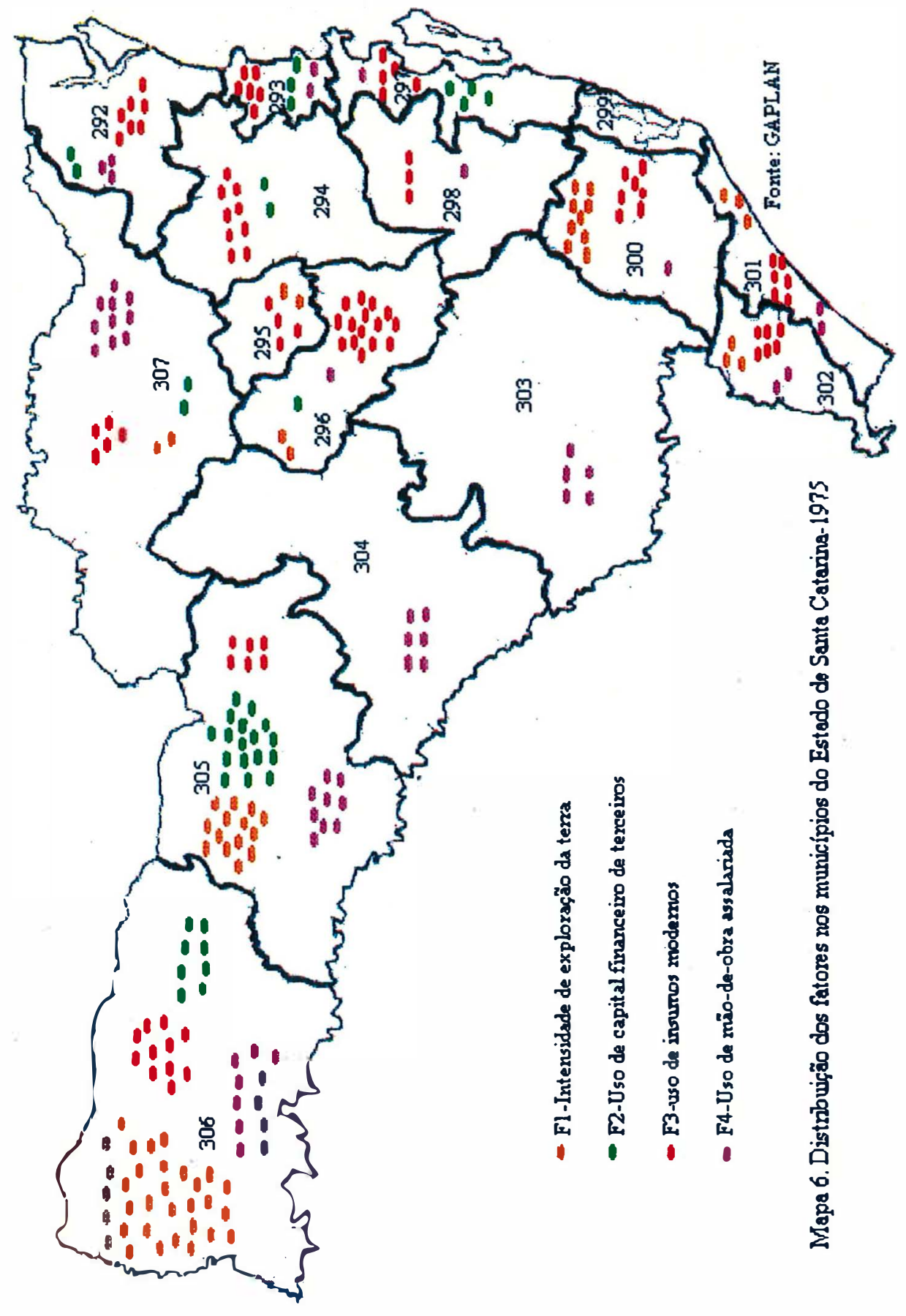


Tabela 19. Percentual de municípios que apresentaram valores positivos (altos e médios) para os fatores, segundo as MRHs do Estado de Santa Catarina, 1975.

\begin{tabular}{|c|c|c|c|c|}
\hline Microrregiāo Homogênea & $\begin{array}{c}\text { Fator } 1 \\
\text { (intensidade de } \\
\text { exploraçāo da } \\
\text { terra) }\end{array}$ & $\begin{array}{c}\text { Fator } 2 \\
\text { (uso de capital } \\
\text { de terceiros } \\
\text { relacionado à } \\
\text { prod. animal) }\end{array}$ & $\begin{array}{c}\text { Fator } 3 \\
\text { (uso de } \\
\text { insumos } \\
\text { modernos) }\end{array}$ & $\begin{array}{c}\text { Fator } 4 \\
\text { (uso de mão- } \\
\text { de-obra } \\
\text { assalariada) }\end{array}$ \\
\hline Col. de Joinville (292) & $\cdots$ & 22,2 & 77,8 & 33,3 \\
\hline Litoral de Itajaí (293) & - & 37,5 & 75,0 & 25,0 \\
\hline Col. de Blumenau (294) & - & 12,5 & 56,3 & - \\
\hline Col. do Itajai do Norte (295) & 50,0 & - & 100,0 & - \\
\hline Col. do Alto Itajaí (296) & 12,5 & 6,25 & 93,8 & 6,25 \\
\hline Florianópolis (297) & - & 40,0 & 50,0 & 10,0 \\
\hline Col. Serrana Catarinense (298) & - & - & 25,0 & 8,30 \\
\hline Litoral de Laguna (299) & - & - & - & - \\
\hline Carbonifera (300) & 52,9 & - & 41,2 & 5,90 \\
\hline Litoral Sul Catarinense (301) & 50,0 & 16,7 & 100,0 & 33,3 \\
\hline Col. do Sul Catarinense (302) & 50,0 & - & 100,0 & 33,3 \\
\hline Campos de Lages (303) & - & - & - & 100,0 \\
\hline Campos de Curitibanos (304) & - & - & - & 75,0 \\
\hline Col. do Rio do Peixe (305) & 46,7 & 56,7 & 20,0 & 30,0 \\
\hline Col. do Oeste Catarinense (306) & 94,1 & 23,5 & 32,4 & 32,3 \\
\hline Planalto de Canoinhas (307) & 15,4 & 15,4 & 38,5 & 76,9 \\
\hline
\end{tabular}

Fonte: Dados da pesquisa

Entretanto, $100 \%$ dos municípios da MRH Litoral do Sul Catarinense (301) e 93,8\% dos municípios da MRH Colonial do Alto Itajaí (296) apresentaram valores positivos para o fator. A MRH Planalto de Canoinhas (307) apresentou valores positivos principalmente para o uso de mão-de-obra assalariada (F4 1975) em 76,9\% dos municípios. Nas microrregiões Colonial do Rio do Peixe (305), Colonial do Oeste Catarinense (306) e Litoral do Sul Catarinense (301) o percentual de municípios com valores positivos para o fator 
foi cerca de $30 \%$, enquanto na MRH Colonial do Alto Itajaí (296) o percentual foi de apenas $6,25 \%$.

Neste período a MRH Colonial do Oeste Catarinense (306) e a MRH Colonial do Rio do Peixe (305) já se destacavam pela produção de milho, suínos, aves e soja, em pequenas propriedades familiares com grande associação às agroindústrias de alimentos que despontaram na década de 1970. A MRH Colonial do Oeste Catarinense (306) era a principal produtora do Estado, em 1975, de produtos como a batata, feijão, mandioca, milho, soja, trigo, bovinos de leite e suínos, seguida, na maior parte dos produtos, pela MRH Colonial do Rio do Peixe (305) que também era a principal produtora de aves do Estado e que se destacou no uso de capital financeiro de terceiros destinado ao incentivo da produção avícola. Estas duas microrregiões juntas já em 1975 representavam mais de $50 \%$ do valor bruto da produção agropecuária catarinense, sendo chamadas, pelo volume de grãos produzidos, de "celeiro catarinense".

Esta região também atraiu um grande contingente de pessoal ocupado, pois na Bacia do Rio Uruguai e seus afluentes estão localizados alguns dos melhores solos do Estado. Entretanto, estes solos que apesar de apresentarem boa fertilidade, a qual dispensa em grande parte o uso de insumos modernos, como adubos, corretivos e defensivos agrícolas, têm relevo que limita o uso da motomecanização sendo mais intenso o uso da força animal. Apesar da agroindústria de aves e suínos estar localizada nesta região isto não impôs necessariamente o uso de tecnologia considerada moderna na agricultura, pois a integração esta relacionada principalmente com a pecuária.

Os municípios pertencentes às principais regiões produtoras de fumo, como no Alto Vale do Rio Itajaí e Litoral Sul ( MRH Litoral do Sul Catarinense, 301, e MRH Colonial do Alto Itajaí, 296), foram os que se destacaram por estarem associados principalmente com o uso de insumos modernos. Nestas 
regiões que apresentam solos mais mecanizáveis, a integração das pequenas propriedades com a agroindústria de fumo tornou obrigatório o uso de insumos modernos, pelo próprio tipo de cultura do fumo e pelos padrões de qualidade exigidos. Na MRH Litoral do Sul Catarinense (301) é destaque além da produção de fumo, o milho, feijão, arroz irrigado, banana e hortaliças em pequenas propriedades. O destaque com relação ao uso de mão-de-obra assalariada na MRH de Planalto de Canoinhas (307) deve-se ao fato de ali estarem estabelecimentos com área média relativamente maior que o restante da região, com solos mais mecanizáveis, e uma signifícativa produção de milho e feijão.

As microrregiões de Carbonífera (300) e Colonial do Sul Catarinense (302), regiões produtoras principalmente de fumo, apresentaram valores positivos para o F1, F3 e F4. A identificação dos municípios das duas microrregiões foi maior com o fator que expressa a intensidade de exploração da terra, sendo bastante expressivo o uso de insumos modernos na MRH Colonial do Sul Catarinense (302) onde $100 \%$ dos municípios apresentou valores positivos para 0 fator. Na MRH de Carbonífera (300) o uso de mão-de-obra assalariada foi pouco expressivo, com apenas 5,9\% dos municípios apresentando valores positivos para o fator, o que indica maior uso de mão-de-obra familiar.

Nas microrregiões Colonial de Joinville (292), Litoral de Itajaí (293) e Florianópolis (297) todos os municípios apresentaram valores antagônicos para o F1 1975, intensidade de exploração da terra, e valores positivos para os demais três fatores. As microrregiões de Florianópolis (297) e Litoral de Itajaí (293), apresentaram valores positivos para o F2, uso de capital financeiro de terceiros, em 40\% e 37,5\% dos seus municípios. Na MRH Litoral de Itajaí (293) o uso de crédito incentivou a produção canavieira e na MRH de Florianópolis (297) a produção avícola. Todas as três microrregiões apresentaram valores positivos para o uso de insumos modernos em $50 \%$, ou mais, dos seus municípios devido às 
culturas da cana-de-açúcar e arroz irrigado. As associações com o uso de mão-deobra assalariada foram mais significativas com os municípios da MRH Colonial de Joinville (292) e MRH de Litoral de Itajaí (293) do que com a MRH de Florianópolis (297).

Os municípios da MRH Colonial de Blumenau (294) apresentaram valores positivos para o uso de capital financeiro de terceiros (F2 1975), em um percentual de $12,5 \%$, e valores positivos para o uso de insumos modernos (F3 1975) em 56,3\% dos municípios. Nesta microrregião são destaques a produção de arroz irrigado e fumo. $\mathrm{Na} \mathrm{MRH} \mathrm{Colonial} \mathrm{do} \mathrm{Itajaí} \mathrm{do} \mathrm{Norte} \mathrm{(295),} \mathrm{onde} \mathrm{é}$ expressiva a produção de fumo, 50\% dos municípios apresentaram valores positivos para o uso intensivo da terra (F1 1975) e 100\% para o uso de insumos modernos (F3 1975). Na MRH Colonial Serrana Catarinense (298), também produtora de fumo, o uso de insumos modernos e de mão-de-obra assalariada, estava em, respectivamente, $25 \%$ e $8,3 \%$ dos municípios, considerados percentuais baixos.

A MRH Campos de Lages (303) e a MRH Campos de Curitibanos (304) apresentaram valores positivos apenas para o uso de mão-de-obra assalariada (F4 1975), respectivamente em $100 \%$ e $75 \%$ dos seus municípios. Estas regiões se distinguem pela pecuária extensiva de bovinos, ovinos, caprinos e eqüínos que demandam mão-de-obra assalariada, sendo também destacável o uso deste tipo de mão-de-obra no cultivo da maçã. A MRH Litoral de Laguna (299) se destacou por apresentar valores negativos para os fatores em todos os seus municípios. 


\subsubsection{Resultados de 1980}

Na Tabela 20 estão os resultados do processamento da matriz X (197 X 22) do ano de 1980 e na Tabela 21 constam os coeficientes de correlação entre as variáveis e os fatores obtidos após a rotação ortogonal pelo método VARIMAX.

Para este ano também foram obtidas quatro raízes características com valores superior a um, representando $75,8 \%$ da variância total, cujos valores em ordem decrescente são: 6,$69 ; 4,27 ; 3,60$ e 2,11 . O primeiro fator captou $30,4 \%$ da variância total, o segundo $19,4 \%$, o terceiro $16,4 \%$ e o quarto $9,60 \%$, sendo estes os fatores analisados.

Em 1980 o primeiro fator (F1 1980) apresentou forte correlação positiva com as variáveis:

TEC6 = valor das despesas com medicamentos e alimentos por unidadeanimal

$\mathrm{CAP} 1=$ valor dos financiamentos por área explorada

CAP2 = valor dos investimentos por área explorada

VAP1 = valor da produção agropecuária por área explorada

VAP2 = valor da produção agropecuária por equivalente-homem este fator é igual ao F2 1975, estando associado ao mesmo conjunto de variáveis, o qual expressa o uso de capital de terceiros (curto e longo prazo) relacionado à produção animal. O fato de em 1980 aparecer como o primeiro fator, significa que o uso do crédito passou de 1975 a 1980 a representar o maior percentual da variância explicada pelos fatores, o que é algo coerente, já que os investimentos e financiamentos foram mais intensos neste período passando a partir daí a decrescer. O F1 1980 foi denominado de uso de capital de terceiros de curto e longo prazo, relacionado à produção animal. 
Tabela 20.Raízes características da matriz de correlações (22 X 22) para os municípios do Estado de Santa Catarina, 1980.

\begin{tabular}{|c|c|c|c|}
\hline FATORES & $\begin{array}{c}\text { RAIZ } \\
\text { CARACTERÍSTICA }\end{array}$ & \% DA VARIÂNCIA & $\%$ ACUMULADO \\
\hline 1 & 6,69 & 30,43 & 30,43 \\
\hline 2 & 4,27 & 19,41 & 49,84 \\
\hline 3 & 3,60 & 16,35 & 66,19 \\
\hline 4 & 2,11 & 9,60 & 75,79 \\
\hline 5 & 0,85 & 3,86 & 79,66 \\
\hline 6 & 0,78 & 3,55 & 83,21 \\
\hline 7 & 0,58 & 2,63 & 85,84 \\
\hline 8 & 0,52 & 2,38 & 88,22 \\
\hline 9 & 0,46 & 2,08 & 90,30 \\
\hline 10 & 0,40 & 1,82 & 92,12 \\
\hline 11 & 0,39 & 1,75 & 93,87 \\
\hline 12 & 0,28 & 1,28 & 95,15 \\
\hline 13 & 0,22 & 0,99 & 96,14 \\
\hline 14 & 0,18 & 0,80 & 96,94 \\
\hline 15 & 0,17 & 0,76 & 97,70 \\
\hline 16 & 0,13 & 0,59 & 98,30 \\
\hline 17 & 0,11 & 0,51 & 98,81 \\
\hline 18 & 0,094 & 0,43 & 99,24 \\
\hline 19 & 0,072 & 0,33 & 99,56 \\
\hline 20 & 0,046 & 0,21 & 99,77 \\
\hline 21 & 0,032 & 0,14 & 99,92 \\
\hline 22 & 0,019 & 0,08 & 100,0 \\
\hline
\end{tabular}

Fonte: Dados da pesquisa

O fator 2 em 1980 (F2 1980) apresentou correlação elevada e positiva com as variáveis:

TEC2 $=$ percentual de estabelecimentos que usam a força animal

TEC7 = número de arados de tração animal por área explorada

CAP5 = valor dos bens em máquinas e instrumentos agrários por área explorada 
Tabela 21. Coeficiente de correlação, comunalidade de cada variável e variância explicada pelos fatores após rotação pelo método VARIMAX, municípios do Estado de Santa Catarina, 1980.

\begin{tabular}{|c|c|c|c|c|c|}
\hline VARIÁVEL & FATOR 1 & FATOR 2 & FATOR 3 & FATOR 4 & COMUNALIDADE \\
\hline TEC1 & $-0,237$ & 0,0161 & 0,152 & 0,651 & 0,503 \\
\hline TEC2 & 0,235 & 0,742 & $-0,312$ & 0,0323 & 0,703 \\
\hline TEC3 & 0,142 & 0,137 & 0,00615 & 0,706 & 0,537 \\
\hline TEC4 & 0,157 & 0,517 & 0,612 & 0,282 & 0,746 \\
\hline TEC5 & 0,0856 & $-0,0235$ & 0,377 & 0,755 & 0,720 \\
\hline TEC6 & 0,913 & 0,123 & $-0,0393$ & $-0,127$ & 0,866 \\
\hline TEC7 & 0,307 & 0,805 & $-0,331$ & $-0,139$ & 0,871 \\
\hline TEC 8 & 0,0226 & $-0,175$ & $-0,215$ & 0,833 & 0,771 \\
\hline CAP1 & $\mathbf{0 , 7 3 0}$ & 0,449 & 0,192 & 0,216 & 0,818 \\
\hline CAP2 & 0,924 & 0,132 & $-0,0310$ & 0,0946 & 0,881 \\
\hline CAP3 & 0,307 & 0,0722 & 0,804 & 0,118 & 0,759 \\
\hline CAP4 & 0,294 & 0,142 & $-0,0807$ & $-0,721$ & 0,633 \\
\hline CAP5 & 0,240 & 0,732 & $-0,0385$ & 0,388 & 0,745 \\
\hline SAT1 & 0,0970 & 0,920 & $-0,0812$ & 0,00807 & 0,863 \\
\hline SAT2 & $-0,0593$ & 0,818 & $-0,0733$ & $-0,224$ & 0,728 \\
\hline VAPI & 0,919 & 0,230 & $-0,156$ & 0,00876 & 0,922 \\
\hline VAP2 & 0,819 & $-0,0661$ & 0,383 & $-0,118$ & 0,834 \\
\hline $\mathrm{HECl}$ & $-0,192$ & $-0,179$ & 0,133 & $-0,737$ & 0,630 \\
\hline $\mathrm{HEC} 2$ & $-0,343$ & $-0,509$ & 0,494 & $-0,378$ & 0,764 \\
\hline RMT 1 & 0,0500 & 0,384 & $-0,877$ & 0,0209 & 0,920 \\
\hline RMT2 & 0,135 & $-0,385$ & 0,802 & 0,0215 & 0,810 \\
\hline RMT3 & $-0,359$ & $-0,214$ & 0,689 & $-0,0382$ & 0,651 \\
\hline VARIÂNCIA \% & 20,7 & 20,5 & 17,4 & 17,2 & \\
\hline
\end{tabular}

Fonte: Dados da pesquisa

SAT1 = percentual de área trabalhada na área total dos estabelecimentos

SAT2 = percentual de área com pastagens plantadas na área total com pastagens

o que se constitui em um conjunto de variáveis igual ao expresso pelo F1 1975, a intensidade de exploração da terra. Entretanto, em 1980, a intensidade de 
exploração da terra deixou de ser o principal fator na explicação da variância total, não deixando porém de ser um dos principais, já que expressa uma das fortes características do Estado de Santa Catarina, o uso intensivo da terra.

Com o terceiro fator (F3 1980) as correlações fortes e positivas foram com as variáveis:

TEC4 $=$ valor das despesas com sementes e mudas por área explorada

CAP3 $=$ valor dos financiamentos por equivalente-homem

RMT2 = percentual dos empregados permanentes no total de equivalentehomem

RMT3 = percentual dos empregados temporários no total de equivalentehomem

a correlação forte e negativa ocorreu com a variável RMT1 (percentual da mãode-obra familiar no total de equivalente-homem), o que se constitui em um conjunto de variáveis semelhante ao expresso pelo fator 4 de 1975, acrescentando-se aqui a variável RMT3, que está relacionada à participação dos empregados temporários no total de equivalentes-homem, reforçando assim o que o fator expressa: o uso de mão-de-obra assalariada, que aumentou a sua importância de 1975 para 1980. O fator 3 (F3 1980) foi denominado de uso de mão-de-obra assalariada.

O quarto fator (F4 1980) apresentou correlação elevada e positiva com as variáveis:

TEC1 = percentual de estabelecimentos que usam a força mecânica

TEC3 = valor das despesas com adubos e corretivos por área explorada

TEC5 = valor das despesas com defensivos agrícolas por área explorada

TEC8 $=$ número de tratores por área explorada

as correlações fortes e negativas foram com as variáveis HECl (hectares de área explorada por trator) e CAP4 (valor dos bens em animais no valor total dos bens), 
se constituindo em um conjunto de variáveis semelhante ao expresso pelo fator 3 de 1975, uso de insumos modernos, sendo acrescentado em 1980 apenas a correlação negativa com a variável CAP4. Esta correlação negativa pode ser interpretada como sendo coerente com o contexto já que o uso de insumos modernos está relacionado ao uso da terra e não a criação animal. $O$ fator 4 de 1980 (F4 1980) foi denominado de uso de insumos modernos.

Em 1980 nenhuma das variáveis consideradas no estudo apresentou uma comunalidade que poderia ser considerada baixa.

No Mapa 7 e na Tabela 22 estão apresentados os resultados obtidos através da análise fatorial para os quatro fatores nos municípios catarinenses no ano de 1980. Apenas quatro microrregiões apresentaram pelo menos um município com valores positivos para os quatro fatores simultaneamente: MRH Litoral de Itajaí (293), MRH de Carbonífera (300), MRH Colonial do Rio do Peixe (305) e MRH Colonial do Oeste Catarinense (306).

Na MRH Litoral de Itajaí (293) 87,5\% dos municípios e na MRH Colonial do Rio do Peixe (305) 70\% dos municípios apresentaram valores positivos para o fator 1, que em 1980 expressou o uso de capital financeiro de terceiros, de curto e longo prazo, indicando o crescimento da sua importância de 1975 para $1980 \mathrm{em}$ explicar a variância total das variáveis. Isto ocorreu devido ao crescimento da avicultura na MRH Colonial do Rio do Peixe (305) e ao crescimento da cultura da cana-de-açúcar na MRH Litoral de Itajaí (293).

Somente na MRH de Carbonífera (300) houve um aumento para $11,8 \%$ de municípios que apresentaram valores positivos para o uso de crédito de terceiros, associados a cultura do fumo e a produção de suínos. Na MRH de Colonial do Oeste Catarinense (306) o percentual de 23,5\% permaneceu o mesmo de 1975. 


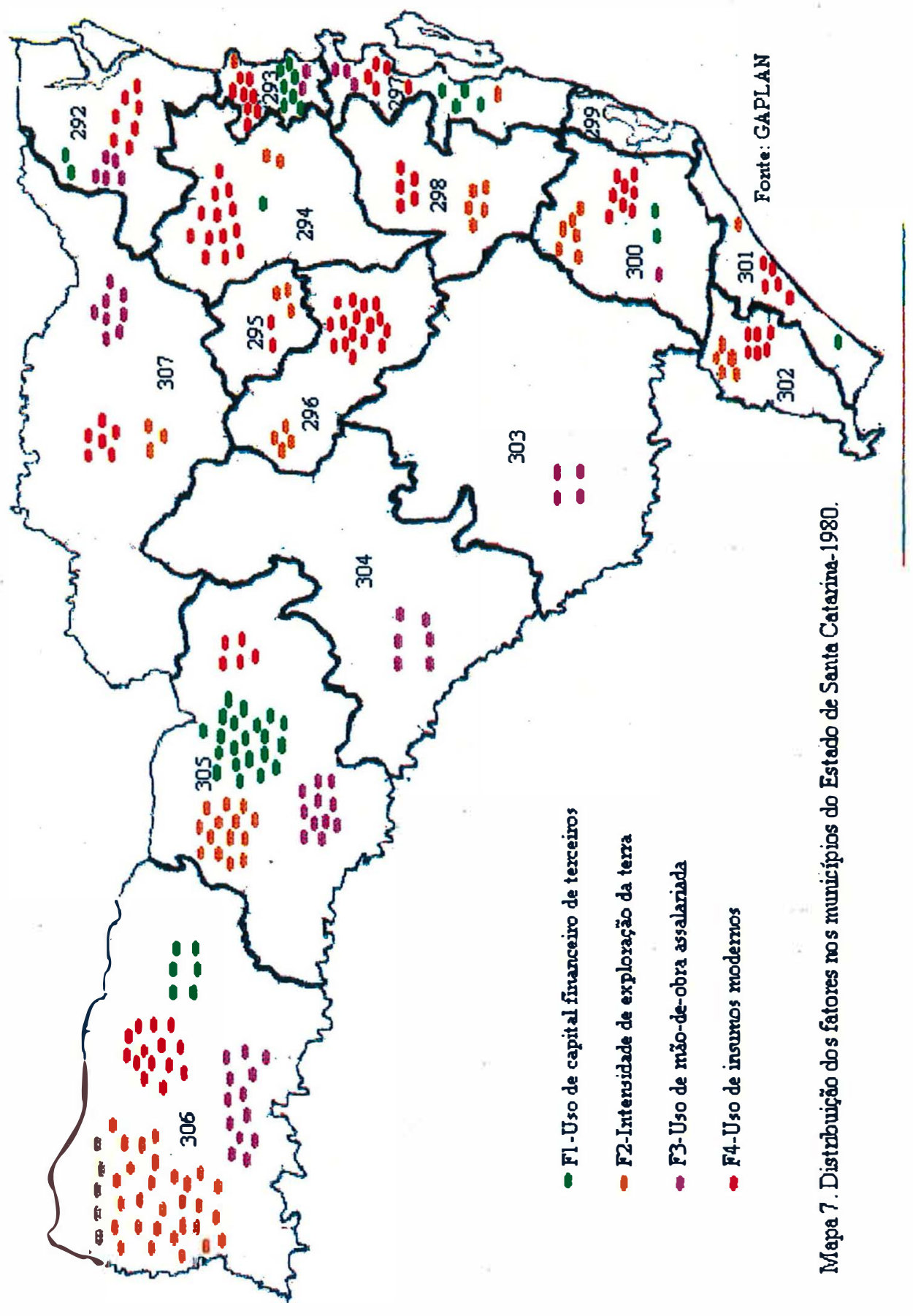


A intensidade de exploração da terra (F2 1980) mostrou-se novamente associada principalmente com os municípios da MRH Colonial do Oeste Catarinense (306). Na tabela 22 verifica-se que $100 \%$ dos municípios apresentaram valores positivos para o fator em 1980.

Tabela 22. Percentual de municípios que apresentaram valores positivos (altos e médios) para os fatores, segundo as MRHs do Estado de Santa Catarina, 1980.

\begin{tabular}{|c|c|c|c|c|}
\hline Microrregiāo Homogênea & $\begin{array}{c}\text { Fator 1 } \\
\text { (uso de capital de } \\
\text { terceiros } \\
\text { relacionado à prod. } \\
\quad \text { animal) }\end{array}$ & $\begin{array}{c}\text { Fator } 2 \\
\text { (intensidade de } \\
\text { exploraçāo da } \\
\text { terra) }\end{array}$ & $\begin{array}{l}\text { Fator } 3 \text { (uso } \\
\text { de māo-de-obra } \\
\text { assalariada) }\end{array}$ & $\begin{array}{l}\text { Fator } 4 \text { (uso } \\
\text { de insumos } \\
\text { modernos) }\end{array}$ \\
\hline Col. de Joinville (292) & 22,2 & 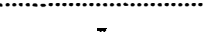 & 55,6 & 77,8 \\
\hline Litoral de Itajaí (293) & 87,5 & 12,5 & 62,5 & 100,0 \\
\hline Col. de Blumenau (294) & 6,25 & 12,5 & - & 81,3 \\
\hline Col. do Itajai do Norte (295) & - & 75,0 & - & 50,0 \\
\hline Col. do Alto Itajai (296) & - & 25,0 & - & 100,0 \\
\hline Florianópolis (297) & 40,0 & - & 30,0 & 50,0 \\
\hline Col. Serrana Catarinense (298) & - & - & - & 41,7 \\
\hline Litoral de Laguna (299) & - & - & - & - \\
\hline Carbonifera (300) & 11,8 & 35,3 & 5,9 & 47,1 \\
\hline Litoral Sul Catarinense (301) & 16,7 & 16,7 & - & 83,3 \\
\hline Col. do Sul Catarinense (302) & - & 83,3 & - & 100,0 \\
\hline Campos de Lages (303) & - & - & 80,0 & - \\
\hline Campos de Curitibanos (304) & - & - & 75,0 & - \\
\hline Col. do Rio do Peixe (305) & 70,0 & 46,7 & 36,7 & 16,7 \\
\hline Col. do Oeste Catarinense (306) & 23,5 & 100,0 & 38,2 & 41,2 \\
\hline Planalto de Canoinhas (307) & - & 23,1 & 61,5 & 46,2 \\
\hline
\end{tabular}

Fonte:Dados da pesquisa

Na MRH Colonial do Rio do Peixe (305) manteve-se o percentual de $46,7 \%$ dos municípios com valores positivos para o fator. Na MRH de Litoral de Itajaí (293) aumentou o percentual de municípios que apresentaram valores 
positivos para a intensidade de exploração da terra e na MRH de Carbonífera (300) diminuiu o percentual de municípios.

$\mathrm{O}$ percentual de municípios que apresentaram valores positivos para o fator 3 de 1980, uso de mão-de-obra assalariada, foi de 62,5\% na MRH Litoral de Itajaí (293) que se destacou na produção de cana-de-açúcar, enquanto nas $\mathrm{MRH}$ Colonial do Rio do Peixe (305) e MRH Colonial do Oeste Catarinense (306) o percentual de municípios manteve-se de forma média. Na MRH de Carbonífera (300) manteve-se o mesmo percentual de 5,9\% de 1975. Nas MRH Litoral de Itajaí (293), MRH de Carbonífera (300) e MRH Colonial do Oeste Catarinense (306), aumentou o percentual de municípios com valores positivos para o fator uso de insumos modernos (F4 1980), com destaque a MRH Litoral de Itajaí (293). $\mathrm{Na} \mathrm{MRH}$ Colonial do Rio do Peixe (305) diminuiu o número de municípios com valores positivos para o uso de insumos modernos.

As microrregiões Colonial de Joinville (292) e de Florianópolis (297) apresentaram valores positivos para o uso de capital financeiro de terceiros (F1 1980), uso de mão-de-obra assalariada (F3 1980) e uso de insumos modernos (F4 1980), regiões que passaram a produzir mais intensamente banana e aves. Na MRH de Planalto de Canoinhas (307) nenhum município apresentou valores positivos para o F1 1980 (uso de capital financeiro de terceiros) devido a cultura do feijão, que recebeu menos crédito, ter superado a cultura do milho no Valor Bruto da Produção. Entretanto, esta microrregião apresentou municípios com valores positivos para a intensidade de exploração da terra, o uso de mão-de-obra assalariada e insumos modernos.

Nas microrregiões Colonial de Blumenau (294) e Litoral Sul Catarinense (301) o antagonismo dos municípios ocorreu apenas com o uso de mão-de-obra assalariada. $\mathrm{O}$ destaque em ambas foram os valores positivos do uso de insumos modernos (F4 1980) em mais de $80 \%$ dos municípios, associado as culturas do 
fumo e do arroz irrigado. Os valores positivos do uso intensivo da terra (F2 1980) e o uso de insumos modernos (F4 1980) estavam em percentuais expressivos de municípios das MRH Colonial do Itajaí do Norte (295), MRH Colonial do Alto Itajaí (296) e MRH Colonial do Sul Catarinense (302), microrregiões onde também predomina a cultura do fumo. A MRH Colonial Serrana Catarinense (298) apresentou valores positivos apenas para o uso de insumos modernos (F4 1980) em $41,7 \%$ dos municípios, sendo o fumo um dos principais produtos ali produzidos.

As microrregiões Campos de Lages (303) e Campos de Curitibanos (304) apresentaram valores positivos apenas para o F3 1980, uso de mão-de-obra assalariada, em respectivamente $80 \%$ e $75 \%$ dos seus municípios, relacionados a pecuária extensiva e também a cultura do alho (MRH 304) e da maçã (MRH 303 e MRH 304). Somente a MRH Litoral de Laguna (299) se destacou por apresentar valores negativos para os fatores em todos os seus municípios.

\subsubsection{Resultados de 1985}

Na Tabela 23 estão os resultados do processamento da matriz X (197 X 22) do ano de 1985 e na Tabela 24 se encontram os valores dos coeficientes de correlação entre as variáveis e os fatores obtidos após a rotação ortogonal pelo método VARIMAX, junto com o valor da comunalidade de cada variável e a proporção da variância que cada fator representa.

Para este ano foram obtidas cinco raízes características com valores superior a um. Entretanto, na análise foram mantidos os quatro primeiros fatores, à semelhança dos anos de 1975 e 1980. As quatro raízes características com valores superiores a um representaram $73,6 \%$ da variância total. Os seus valores 
em ordem decrescente são: 6,$84 ; 5,06 ; 2,95$ e 1,35 . O primeiro fator captou $31,1 \%$ da variância total, o segundo $23,0 \%$, o terceiro $13,4 \%$ e o quarto $6,13 \%$.

Tabela 23.Raízes características da matriz de correlações (22 X 22) para os municípios do Estado de Santa Catarina, 1985.

\begin{tabular}{|c|c|c|c|}
\hline FATORES & $\begin{array}{c}\text { RAIZ } \\
\text { CARACTERÍSTICA }\end{array}$ & \% DA VARIÂNCIA & $\%$ ACUMULADO \\
\hline 1 & 6,84 & 31,08 & 31,08 \\
\hline 2 & 5,06 & 23,02 & 54,10 \\
\hline 3 & 2,95 & 13,40 & 67,50 \\
\hline 4 & 1,35 & 6,13 & 73,63 \\
\hline 5 & 1,06 & 4,83 & 78,46 \\
\hline 6 & 0,77 & 3,49 & 81,95 \\
\hline 7 & 0,65 & 2,95 & 84,90 \\
\hline 8 & 0,61 & 2,78 & 87,68 \\
\hline 9 & 0,50 & 2,27 & 89,95 \\
\hline 10 & 0,43 & 1,95 & 91,91 \\
\hline 11 & 0,40 & 1,82 & 93,72 \\
\hline 12 & 0,34 & 1,54 & 95,27 \\
\hline 13 & 0,27 & 1,24 & 96,50 \\
\hline 14 & 0,22 & 1,01 & 97,51 \\
\hline 15 & 0,15 & 0,67 & 98,18 \\
\hline 16 & 0,12 & 0,52 & 98,70 \\
\hline 17 & 0,095 & 0,43 & 99,14 \\
\hline 18 & 0,076 & 0,35 & 99,48 \\
\hline 19 & 0,060 & 0,27 & 99,76 \\
\hline 20 & 0,029 & 0,13 & 99,89 \\
\hline 21 & 0,017 & 0,08 & 99,96 \\
\hline 22 & 0,0078 & 0,04 & 100,0 \\
\hline
\end{tabular}

Fonte: Dados da pesquisa

O primeiro fator (F1 1985) apresentou correlação elevada e positiva com as seguintes variáveis:

TEC2 $=$ percentual de estabelecimentos que usam a força animal TEC7 = número de arados de tração animal por área explorada 
SAT1 = percentual de área trabalhada na área total dos estabelecimentos

RMT1 = percentual da mão-de-obra familiar no total de equivalentehomem

e correlação negativa e elevada com as variáveis:

HEC2 = hectares de área explorada por equivalente-homem

RMT2 = percentual de empregados permanentes no total de equivalentehomem

RMT3 = percentual dos empregados temporários no total de equivalentehomem

as correlações positivas (variáveis TEC2, TEC7, SAT1 e RMT1) indicam que o fator expressa o uso de mão-de-obra familiar (variável RMT1) associada à intensidade de exploração da terra (TEC7 e SAT1) que se utiliza da força animal (variáveis TEC2 e TEC7).

As correlações negativas relacionadas com o uso da mão-de-obra assalariada (variáveis HEC2, RMT2 e RMT3) reforçam a relação do fator com o uso da mão-de-obra familiar. Neste ano, o fato do valor em bens e máquinas e instrumentos agrários por área explorada (CAP5) ter deixado de estar relacionado ao uso da terra, deve-se ao nível de recursos destinados aos investimentos que de 1975 a 1985 se apresentou decrescente. Este fator, F1 1985, foi denominado de intensidade de exploração da terra associada ao uso de mão-de-obra familiar e força animal.

O segundo fator de 1985 apresentou correlações bastante fortes, próximas à unidade, e positivas com as variáveis:

CAP2 = valor dos investimentos por área explorada

VAP1 = valor da produção agropecuária por área explorada

VAP2 = valor da produção agropecuária por equivalente-homem 
o que indica o uso de capital financeiro próprio na atividade agropecuária (variável CAP2), de uma forma geral, a qual proporciona retorno no longo prazo (variáveis VAP1 e VAP2). O fator 2 de 1985 (F2 1985) foi denominado de uso de capital financeiro próprio de longo prazo.

Tabela 24. Coeficiente de correlação, comunalidade de cada variável e variância explicada pelos fatores após rotação pelo método VARIMAX, mucípios do Estado de Santa Catarina, 1985.

\begin{tabular}{cccccc} 
VARIAVEL & FATOR 1 & FATOR 2 & FATOR 3 & FATOR 4 & COMUNALIDADE \\
\hline TEC1 & $-0,311$ & $-0,202$ & 0,0873 & $\mathbf{0 , 7 5 6}$ & 0,717 \\
TEC2 & $\mathbf{0 , 7 7 4}$ & 0,271 & 0,180 & $-0,0787$ & 0,711 \\
TEC3 & 0,191 & 0,103 & 0,309 & $\mathbf{0 , 7 7 4}$ & 0,741 \\
TEC4 & 0,292 & 0,299 & $\mathbf{0 , 7 6 2}$ & $-0,0377$ & 0,757 \\
TEC5 & $-0,208$ & $-0,174$ & 0,548 & $\mathbf{0 , 6 5 0}$ & 0,797 \\
TEC6 & 0,280 & 0,414 & 0,385 & $-0,288$ & 0,482 \\
TEC7 & $\mathbf{0 , 6 9 7}$ & 0,534 & 0,0637 & $-0,264$ & 0,843 \\
TEC8 & 0,0985 & 0,00756 & $-0,120$ & $\mathbf{0 , 7 6 0}$ & 0,601 \\
CAP1 & 0,00292 & 0,185 & $\mathbf{0 , 7 7 5}$ & 0,419 & 0,811 \\
CAP2 & 0,127 & $\mathbf{0 , 9 2 5}$ & 0,0102 & 0,0458 & 0,873 \\
CAP3 & $-0,284$ & 0,00423 & $\mathbf{0 , 8 2 9}$ & 0,222 & 0,817 \\
CAP4 & 0,294 & 0,283 & $-0,258$ & $-0,581$ & 0,570 \\
CAP5 & 0,434 & 0,240 & 0,527 & 0,418 & 0,699 \\
SAT1 & $\mathbf{0 , 6 5 1}$ & 0,326 & 0,422 & $-0,0618$ & 0,712 \\
SAT2 & 0,462 & 0,464 & 0,0528 & $-0,339$ & 0,546 \\
VAP1 & 0,226 & $\mathbf{0 , 9 4 9}$ & 0,121 & $-0,00451$ & 0,966 \\
VAP2 & $-0,00447$ & $\mathbf{0 , 9 3 6}$ & 0,223 & $-0,0820$ & 0,932 \\
HEC1 & $-0,538$ & $-0,0317$ & $-0,207$ & $-0,558$ & 0,644 \\
HEC2 & $\mathbf{- 0 , 8 1 2}$ & $-0,128$ & $-0,196$ & $-0,245$ & 0,774 \\
RMT1 & $\mathbf{0 , 8 4 2}$ & 0,0400 & $-0,405$ & $-0,0547$ & 0,877 \\
RMT2 & $\mathbf{- 0 , 7 0 5}$ & 0,0298 & 0,548 & 0,0231 & 0,799 \\
RMT3 & $\mathbf{- 0 , 7 1 5}$ & $-0,0448$ & 0,112 & 0,0577 & 0,528 \\
VARIÂNCIA \% & 23,4 & 17,5 & 16,4 & 16,2 & \\
\hline
\end{tabular}

Fonte: Dados da pesquisa

Com o fator 3 as correlações foram elevadas e positivas com as variáveis:

TEC4 $=$ valor das despesas com sementes e mudas por área explorada 
CAP1 $=$ valor dos financiamentos por área explorada

$\mathrm{CAP} 3=$ valor dos financiamentos por equivalente-homem este conjunto de variáveis (TEC4, CAP1 e CAP3) indica o uso de capital financeiro de terceiros, já que são financiamentos direcionados às atividades de custeio da produção, no curto prazo, indicado pelas despesas com sementes e mudas. O fator 3 (F3 1985) foi chamado de uso de capital financeiro de terceiros de curto prazo.

O fator 4 de 1985 (F4 1985) apresentou correlações elevadas e positivas com as variáveis:

TEC1 = percentual de estabelecimentos que usam a força mecânica

TEC3 = valor das despesas com adubos e corretivos por área explorada

TEC5 = valor das despesas com defensivos agrícolas por área explorada

TEC8 = número de tratores por área explorada

expressando, assim, o chamado uso de insumos modernos (TEC1, TEC3, TEC5 e TEC8) também presente nos anos de 1975 e 1980, e que se constitui no conjunto de insumos utilizados no que foi denominado de modernização da agricultura. $O$ F4 1985 foi chamado de uso de insumos modernos.

Os resultados do ano de 1985, obtidos através da análise fatorial, para os quatro fatores nos municípios catarinenses estão apresentados no Mapa 8 e na Tabela 25. Apenas três microrregiões homogêneas, a MRH Litoral do Sul Catarinense (301), MRH Colonial do Rio do Peixe (305) e a MRH Colonial do Oeste Catarinense (306) apresentaram pelo menos um município com valores positivos para os quatro fatores simultaneamente.

Estas três microrregiões apresentaram valores positivos para o F1 1985, intensidade de exploração da terra associado ao uso de mão-de-obra familiar e a força animal, em $50 \%$ ou mais de seus municípios estando o maior percentual na MRH Colonial do Oeste Catarinense ( 306 ) onde 88,2\% dos municípios 


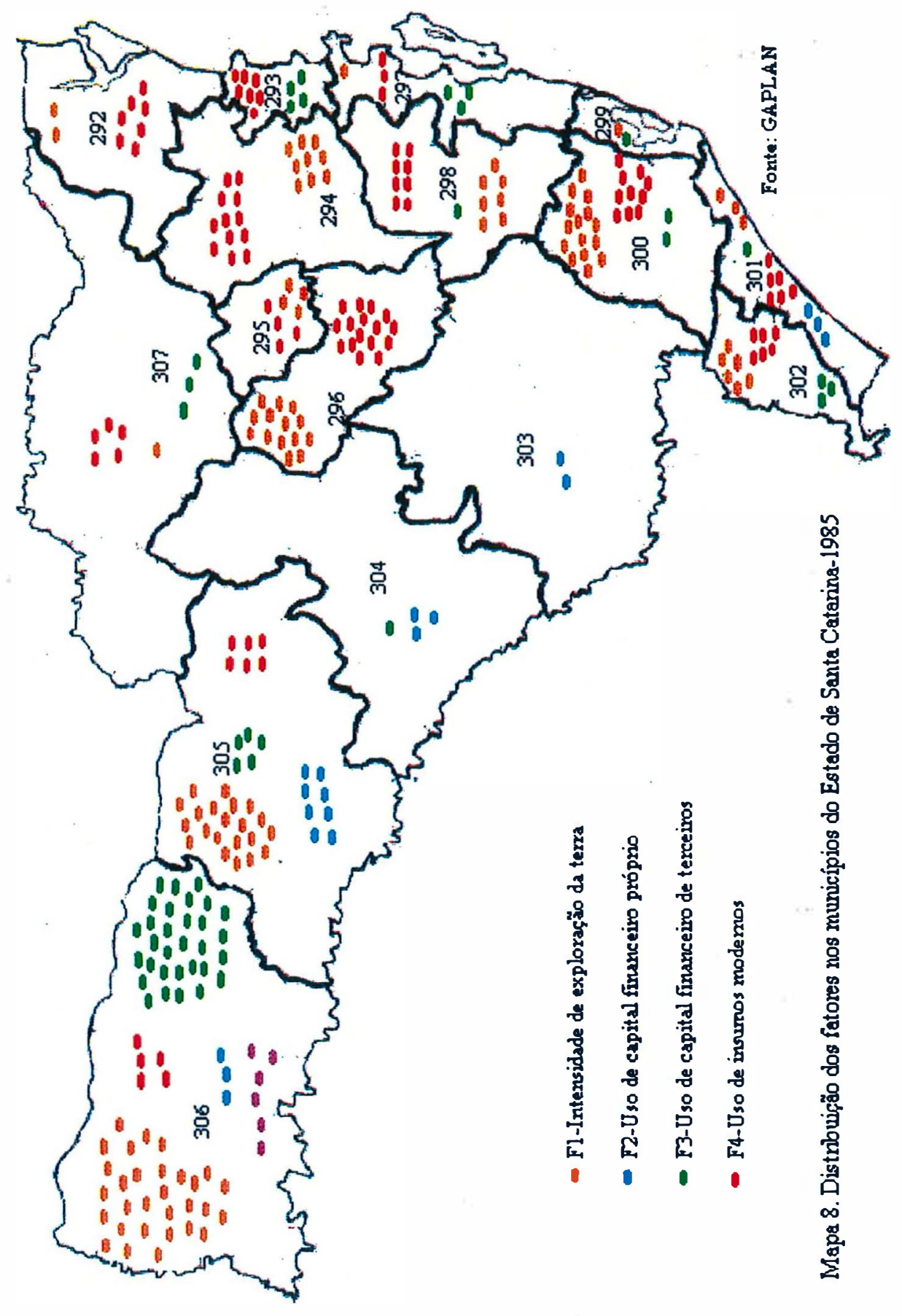


apresentaram valores positivos para o F1 1985.

O uso de capital financeiro próprio de longo prazo (F2 1985) foi destaque na MRH Litoral do Sul Catarinense (301) onde 50\% dos municípios apresentaram valores positivos para o fator, principalmente aqueles que apresentam solos propícios a plantação de hortaliças, indicando uma atividade que proporciona bons retornos.

Tabela 25. Percentual de municípios que apresentaram valores positivos (altos e médios) para os fatores, segundo as MRHs do Estado de Santa Catarina, 1985.

\begin{tabular}{|c|c|c|c|c|}
\hline Microrregiāo Homogênea & $\begin{array}{c}\text { Fator } 1 \\
\text { (intensidade de } \\
\text { exploração da } \\
\text { terra) }\end{array}$ & $\begin{array}{c}\text { Fator } 2 \\
\text { (uso de capital } \\
\text { financeiro } \\
\text { próprio) }\end{array}$ & $\begin{array}{c}\text { Fator } 3 \\
\text { (uso de capital } \\
\text { financeiro de } \\
\text { terceiros) }\end{array}$ & $\begin{array}{c}\text { Fator } 4 \\
\text { (uso de } \\
\text { insumos } \\
\text { modernos) }\end{array}$ \\
\hline Col. de Joinville (292) & 22,2 & - & - & 77,8 \\
\hline Litoral de Itajaí (293) & - & - & 50,0 & 87,5 \\
\hline Col. de Blumenau (294) & 56,3 & - & - & 75,0 \\
\hline Col do Itajaí do Norte (295) & 100,0 & - & - & 100,0 \\
\hline Col. do Alto Itajaí (296) & 87,5 & - & - & 100,0 \\
\hline Florianópolis (297) & 10,0 & - & 30,0 & 30,0 \\
\hline Col. Serrana Catarinense (298) & 58,3 & - & 8,33 & 66,7 \\
\hline Litoral de Laguna (299) & 33,3 & - & 33,3 & - \\
\hline Carbonífera (300) & 88,2 & - & 11,8 & 58,8 \\
\hline Litoral Sul Catarinense (301) & 50,0 & 50,0 & 16,7 & 100,0 \\
\hline Col. do Sul Catarinense (302) & 100,0 & - & 50,0 & 100,0 \\
\hline Campos de Lages (303) & - & 28,6 & - & - \\
\hline Campos de Curitibanos (304) & - & 37,5 & 12,5 & - \\
\hline Col. do Rio do Peixe (305) & 70,0 & 26,7 & 16,7 & 20,0 \\
\hline Col. do Oeste Catarinense (306) & 88,2 & 8,82 & 91,2 & 14,7 \\
\hline Planalto de Canoinhas (307) & 7,69 & - & 23,1 & 38,5 \\
\hline
\end{tabular}

Fonte: Dados da pesquisa

A MRH Colonial do Oeste Catarinense (306) apresentou 91,2\% dos seus municípios com valores positivos para o uso de capital financeiro de terceiros no 
curto prazo (F3 1985) relacionado principalmente às despesas de custeio com sementes e mudas e a cultura do milho. Nas outras duas microrregiões apenas $16,7 \%$ dos municípios apresentaram valores positivos para o fator. No uso de insumos modernos (F4 1985) destacou-se a MRH Litoral do Sul Catarinense (301) onde $100 \%$ dos municípios apresentaram valores positivos para o fator. Nas MRH Colonial do Rio do Peixe (305) e MRH Colonial do Oeste Catarinense (306) os percentuais foram de $20 \%$ e $14,7 \%$ dos municípios, repectivamente. O uso de crédito reflete aqui os efeitos da política de crédito vigente na década de 1980, que associada à crise econômica, diminuiu os recursos destinados aos financiamentos.

A associação do fator 3 com o financiamento de atividades de custeio, como o valor das despesas com sementes e mudas por área explorada, e o fato dos valores positivos deste fator estarem principalmente nos municípios da $\mathrm{MRH}$ Colonial do Oeste Catarinense (306) indica ter havido um incentivo a esta microrregião, considerada como a principal produtora de grãos do Estado. As associações com sementes e mudas, e não com outros tipos de insumos, já foi caracterizada pelo tipo de solo predominante na região.

A MRH de Florianópolis (297), MRH Colonial Serrana Catarinense (298), MRH de Carbonífera (300), MRH Colonial do Sul Catarinense (302) e MRH Planalto de Canoinhas (307) apresentaram valores negativos apenas para o uso de capital financeiro próprio de longo prazo. Os valores positivos da intensidade de exploração da terra (F1 1985) ocorreram em 88,2\% dos municípios da MRH de Carbonífera (300) e 100\% dos municípios da MRH Colonial do Sul Catarinense (302), enquanto os valores positivos do uso de capital financeiro de terceiros de curto prazo (F3 1985) estavam em 50\% dos municípios da MRH Colonial do Sul Catarinense (302) e na MRH de Florianópolis (297) em 30\%. No uso de insumos modernos (F4 1985) também foi destaque a MRH Colonial do Sul Catarinense 
(302) onde $100 \%$ dos municípios apresentaram valores positivos para o fator. Estas microrregiões, com exceção da MRH de Florianópolis (297) que produzia principalmente aves em 1985, tinham como um dos principais produtos o fumo.

A identificação com a intensidade de exploração da terra, associado ao uso de mão-de-obra familiar e tração animal (F1 1985) e o uso de insumos modernos (F4 1985), ocorreu com municípios de quatro microrregiões: MRH Colonial de Joinville (292), MRH Colonial de Blumenau (294), MRH Colonial do Itajaí do Norte (295) e MRH Colonial do Alto Itajaí (296), sendo que, respectivamente 100\% dos municípios da MRH Colonial de Itajaí do Norte (295), 87,5\% da MRH Colonial do Alto Itajaí (296), 56,3\% da MRH Colonial de Blumenau (294) e 22,2\% da MRH Colonial de Joinville (292) apresentaram valores positivos para o F1 1985. O uso de insumos modernos (F4 1985) foi mais intenso atingindo 100\% dos municípios das MRH Colonial do Itajaí do Norte (295) e MRH Colonial do Alto Itajaí (296) e 77,8\% e 75\% da MRH Colonial de Joinville (292) e MRH Colonial de Blumenau (294). O arroz irrigado e o fumo eram os principais produtos ali produzidos.

A MRH Litoral de Itajaí (293) apresentou valores positivos para o uso de capital financeiro de terceiros de curto prazo (F3 1985) em 50\% dos municípios e o uso de insumos modernos (F4 1985) em 87,5\% associados a cultura canavieira. $\mathrm{Na}$ MRH de Laguna (299) apenas um município, representando 33,3\%, apresentou valores positivos para o F1 1985, intensidade de exploração da terra, e o F3 1985, uso de capital financeiro de terceiros de curto prazo, associados a cultura do arroz irrigado. Os municípios da MRH Campos de Curitibanos (304) apresentaram valores positivos para o uso de capital financeiro próprio no longo prazo (F2 1985) e de terceiros no curto prazo (F3 1985), enquanto os municípios da MRH Campos de Lages (303) apresentaram valores positivos apenas para o F2 1985. 


\subsection{Resumo dos resultados de 1920 a 1985}

\subsubsection{Estrutura fundiária}

Na Tabela 26 estão os resultados relativos ao número de estabelecimentos, área total, área média, os valores do índice de Gini e os percentuais da área total correspondente aos 50\% menores estabelecimentos (A50-) e aos 5\% maiores estabelecimentos (A5+) agropecuários de Santa Catarina nos anos de 1920, 1950, 1975, 1980 e 1985. Verifica-se que o número total de estabelecimentos evoluiu de 1920 para 1985 apresentando sempre acréscimos, e mais destacadamente no período 1920-1975, enquanto a área total dos estabelecimentos foi crescente de 1920 até 1980, decrescendo ligeiramente de 1980 para 1985.

Em 1920, a área média dos estabelecimentos no Estado ultrapassava os 100 hectares (105,8 hectares), diminuindo para 50,9 hectares em 1950, e a partir daí apresentou sempre valores inferiores a 50 hectares ficando na média de 31,6 hectares em 1985, o que permite considerá-las, em períodos mais recentes, como pequenas propriedades. Devido ao fato de predominarem as pequenas propriedades, Santa Catarina apresenta um dos mais baixos índices de Gini do Brasil, o que não significa, entretanto, que não haja concentração fundiária no Estado.

Pode ser verificado na Tabela 26 que em 1920, ano que em foram excluídas as propriedades de menor produção, o índice de Gini era próximo a unidade, indicando muito forte concentração fundiária, diminuindo em 1950 para 0,674 e em 1975 para 0,659, enquanto nas últimas décadas vem mostrando um pequeno aumento no grau de desigualdade da posse da terra, apresentando valores de 0,680 em 1980 e 0,685 em 1985. O valor do percentual da área total correspondente aos 50\% menores estabelecimentos (A50-) aumentou de 7,45\% 
em 1920 para $11 \%$ em 1950 e a partir daí diminuiu progressivamente no Estado até 1985 , enquanto o percentual correspondente aos $5 \%$ maiores estabelecimentos (A5+) foi decrescente de 1920 até 1975 e crescente de 1975 para 1985.

Tabela 26. Número, área total, área média, índice de Gini e percentual da área total correspondente aos 50\% menores e 5\% maiores estabelecimentos agropecuários do Estado de Santa Catarina, 1920, 1950, 1975, 1980 e 1985.

\begin{tabular}{lccccc} 
Estabelecimentos & $\mathbf{1 9 2 0}$ & $\mathbf{1 9 5 0}$ & $\mathbf{1 9 7 5}$ & $\mathbf{1 9 8 0}$ & $\mathbf{1 9 8 5}$ \\
\hline Número total & 33.742 & 104.527 & 206.497 & 215.992 & 234.851 \\
Área total & 3.571 .386 & 5.318 .272 & 6.877 .137 & 7.472 .914 & 7.418 .590 \\
Área média & 105,8 & 50,9 & 33,3 & 34,6 & 31,6 \\
Índice de Gini & 0,766 & 0,674 & 0,659 & 0,680 & 0,685 \\
A50\%- & 7,45 & 11,0 & 10,8 & 10,1 & 9,94 \\
A5\%+ & 61,9 & 50,2 & 46,5 & 49,7 & 50,1 \\
Municípios & 34 & 52 & 197 & 197 & 199 \\
\hline
\end{tabular}

Fonte: Dados da pesquisa

No período 1920-1985, apesar de terem ocorrido alterações significativas no número de municípios, número total e área total dos estabelecimentos agropecuários, a concentração fundiária, na maior parte dos municípios, durante todo o período, esteve na faixa de média e forte. Entre 1920 e 1950, as mudanças ocorridas no número de municípios foram menos intensas do que no período 1950-1975, onde o número de municípios quadruplicou, enquanto entre 19751985 o quadro foi estável.

As maiores concentrações fundiárias, medidas pelo índice de Gini, estavam em 1920 em municípios de regiões do Litoral e do Planalto e em 1950 especificamente no Planalto, com exceção nos dois anos da MRH Colonial do 
Oeste Catarinense, representada apenas pelo município de Chapecó, que também apresentou muito forte concentração fundiária. Entre 1975-1985 as maiores concentrações fundiárias estavam novamente em regiões litorâneas e do Planalto. O número de minifúndios foi crescente no estado de 1950 a 1985 com percentuais de respectivamente $19,8 \%, 33,9 \%, 35,1 \%$ e $39,1 \%$ dos estabelecimentos recenseados. Em todo o período, os maiores percentuais de estabelecimentos com área inferior a 10 hectares estavam em municípios de regiões litorâneas, e os menores percentuais em municípios de regiões do Planalto.

No período 1975-1985 um percentual expressivo de municípios apresentou diminuição no número total de estabelecimentos e aumento da área média, localizados no Litoral Norte e Litoral do Estado, regiões ligadas à cultura da canade-açúcar para fins industriais que levaram à diminuição do número de pequenas propriedades e ao êxodo rural. Por outro lado, no Planalto, na MRH de Campos de Lages (303), que tem os estabelecimentos com as maiores áreas médias do Estado, todos os municípios apresentaram diminuição da área média associado ao processo migratório de japoneses para propriedades desmembradas desta região. Entretanto, os valores do índice de Gini, com exceção desta microrregião homogênea, aumentou na maior parte dos municípios catarinenses indicando aumento da concentração fundiária.

\subsubsection{Pessoal ocupado}

$\mathrm{Na}$ Tabela 27 constam os resultados referentes ao pessoal ocupado na agricultura de Santa Catarina, em equivalentes-homem e por percentual de categoria de trabalhador, nos anos de 1950, 1975, 1980 e 1985, com exceção do ano de 1920, onde os resultados se referem apenas ao número de pessoas ocupadas, convertidas em equivalentes-homem, pois não havia este tipo de 
divisão. Os resultados mostram que o pessoal ocupado na agricultura foi crescente de 1920 a 1985 e mais acentuadamente nos períodos de 1920-1950 e 1950-1975, onde duplicou, permanecendo estável no período 1975-1985.

A mão-de-obra familiar representava o maior percentual da mão-de-obra rural nos municípios catarinenses nos anos de 1950, 1975, 1980 e 1985. Este percentual aumentou de 85,7\% em 1950 para 91\% em 1975 havendo, então, um declínio na participação deste tipo de mão-de-obra até 1985. As demais categorias foram pouco expressivas na composição da mão-de-obra rural.

Em 1950 a segunda categoria mais representativa da mão-de-obra rural era o emprego temporário, seguido do emprego permanente e da parceria. No período 1975-1980 a mão-de-obra permanente se equilibrou com a mão-de-obra temporária, em percentuais próximos, sendo em 1985 novamente superada pela mão-de-obra temporária, seguida em todos os anos pelos serviços de empreitada e de parceiros e outra condição.

Tabela 27. Pessoal ocupado na agricultura em equivalentes-homem e composição percentual da mão-de-obra rural no Estado de Santa Catarina, 1920, $1950,1975,1980$ e 1985.

\begin{tabular}{|c|c|c|c|c|c|c|}
\hline Ano & $\begin{array}{c}\text { Pessoal } \\
\text { ocupado EH }\end{array}$ & Familiar & Permanente & Temporária & $\begin{array}{c}\text { Parceiros/outra } \\
\text { condição* }\end{array}$ & $\begin{array}{l}\text { Serviços de } \\
\text { empreitada }\end{array}$ \\
\hline 1920 & 139.361 & - & - & - & - & - \\
\hline 1950 & 286.461 & 85,7 & 2,56 & 9,34 & 2,40 & - \\
\hline 1975 & 622.774 & 91,0 & 3,20 & 3,09 & 0,662 & 2,04 \\
\hline 1980 & 628.696 & 86,9 & 5,54 & 5,62 & 0,842 & 1,12 \\
\hline 1985 & 689.516 & 84,1 & 5,99 & 6,63 & 1,17 & 2,08 \\
\hline
\end{tabular}

Fonte: Dados da pesquisa

*A categoria de outra condição não havia em 1950 
Em 1920 o maior contingente de pessoas ocupadas, em equivalenteshomem, estava situado em regiões litorâneas e próximas ao Litoral, primeiras regiões de colonização do Estado. No ano de 1950, já havendo uma maior ocupação do território, outras regiões como o Oeste do Estado (Colonial do Rio do Peixe e Colonial do Oeste Catarinense) aparecem, além do Litoral, como apresentando os maiores contingentes de pessoal ocupado.

No período 1975-1985 se destacou a região de última colonização do Estado, a MRH Colonial do Oeste Catarinense (306), por apresentar o maior número de pessoal ocupado na agricultura do Estado. Este fato foi relacionado principalmente a localização das agroindústrias de cames e as terras de boa fertilidade existentes na bacia do rio Uruguai, que apesar de apresentarem relevo que difículta a mecanização, agravado neste último período do estudo por um certo esgotamento da fertilidade natural das terras, ainda conduziram a região a se distinguir como a maior produtora de grãos do Estado.

A mão-de-obra familiar se apresentou como o principal componente da mão-de-obra rural durante o período 1950-1985. Entre 1950-1975 houve um aumento da participação deste tipo de mão-de-obra acompanhando o período de maior expansão da fronteira agrícola, enquanto no período 1975-1985 houve um declínio na sua participação, seguido do aumento do emprego permanente e temporário em todas as microrregiões do Estado, relacionado ao processo de industrialização urbana e rural que levou à transformações na composição da mão-de-obra rural alterando de uma forma geral as relações sociais de produção no campo. 


\subsubsection{Modernização da agricultura}

Os resultados da análise fatorial mostraram que no período em estudo: 1920, 1950, 1975, 1980 e 1985 a intensidade de exploração da terra associada ao uso de mão-de-obra familiar e a tração animal, foi o principal fator na explicação das transformações pelas quais passou a agricultura dos municípios de Santa Catarina, com exceção do ano de 1980, quando foi o segundo mais importante. Isto significa que os períodos antes e depois das intensas políticas de modernização tecnológica da agricultura, adotadas na década de 1960, foram caracterizados pelo mesmo fator. Para o período mais intenso de modernização no País este resultado diverge do obtido para outras regiões brasileiras, fato que está associado ao grande número de pequenas propriedades, que se utilizam basicamente da mão-de-obra familiar, ou mesmo às propriedades maiores existentes no Estado de Santa Catarina, cujo tipo de solo e relevo são limitantes ao uso da tração mecânica.

As análises em cada ano mostraram que havia a busca de uma modernização desde o início do século, que foi limitada pelas características das propriedades e dos solos predominantes. Verificou-se que em nenhum dos anos em estudo a distribuição dos fatores pelos municípios ocorreu de forma homogênea, isto é, as transformações foram mais intensas em algumas regiões do que em outras.

No ano de 1920, os outros dois fatores que seguiram a intensidade de exploração da terra (F1 1920) foram o uso de mão-de-obra feminina associada aos instrumentos agrários (F2 1920) e o uso de máquinas de beneficiamento (F3 1920), fatores que de certa forma já expressavam o uso de equipamentos no sentido de melhorar a produtividade da terra e do trabalho. Entretanto, neste ano os instrumentos agrários eram movidos basicamente à força animal e as máquinas 
movidas a força mecânica (hidráulica e a vapor) eram destinadas ao beneficiamento dos produtos e não ao seu cultivo. Apenas três microrregiões apresentaram valores positivos para os três fatores: MRH de Florianópolis (297), MRH Colonial Serrana Catarinense (298) e MRH de Carbonífera (300). Estes resultados evidenciam que no ano de 1920 já havia a intenção de uma modernização e que a mesma ocorria com os instrumentos disponíveis.

Em 1950 junto com a intensidade de exploração da terra associada ao uso de mão-de-obra familiar (F1 1950) estavam os investimentos em bens de capital (F2 1950), uso de tração animal (F3 1950) e o uso de insumos modernos (F4 1950). Quatro microrregiões apresentaram os quatro fatores simultaneamente, em pelo menos um município: MRH Colonial de Joinville (292), MRH Colonial de Blumenau (294), MRH de Carbonífera (300) e MRH Colonial do Rio do Peixe (305), que eram as mais importantes do Estado naquele ano. Em 1950 o fato de termos o uso de insumos modernos, um fator que expressa modernização, entre os fatores explicativos, denota novamente a intenção de modernizar a agricultura, mas devido às características já mencionadas a intensidade de exploração da terra associada à mão-de-obra familiar e a tração animal explicava melhor o processo.

Em 1975 seguiram-se ao principal fator o uso de capital de terceiros, de curto e longo prazo, relacionado à produção animal (F2 1975), o uso de insumos modernos (F3 1975) e o uso de mão-de-obra assalariada (F4 1975). Cinco microrregiões, das 16 existentes, apresentaram os quatro fatores positivos: Colonial do Alto Itajaí (296), Litoral Sul Catarinense (301), Colonial do Rio do Peixe (305), Colonial do Oeste Catarinense (306) e Planalto de Canoinhas (307). Neste ano percebe-se a intenção de modernizar a agricultura com os instrumentos utilizados pela política agrícola, mas as condições de uso da terra e do tipo de mão-de-obra predominaram. 
Em 1980 os fatores foram os mesmos de 1975 em posições diferentes. Neste ano, o uso de capital de terceiros, de curto e longo prazo, relacionado à produção animal (F1 1980) foi o fator mais importante. A intensidade de exploração da terra (F2 1980), o uso de mão-de-obra assalariada (F3 1980) e o uso de insumos modernos (F4 1980) foram os três outros fatores. Em 1980 podemos considerar que houve em Santa Catarina uma modernização, pois o uso do crédito foi o fator mais importante seguido do uso de insumos modernos e de mão-de-obra assalariada, apesar da intensidade de exploração da terra associada a força animal ser um dos fatores explicativos do processo.

No Estado, as microrregiões de Litoral de Itajaí (293), Carbonífera (300), Colonial do Rio do Peixe (305) e Colonial do Oeste Catarinense (306) foram as que apresentaram os quatro fatores positivos. A MRH de Litoral de Itajaí (293) se destacou pelo desenvolvimento da cultura canavieira, a MRH de Carbonífera (300), pela cultura do fumo e as MRH Colonial do Rio do Peixe (305) e Colonial do Oeste Catarinense (306) pelas criações de aves, suínos e produção de milho e soja, isto é, a modernização estaria relacionada às regiões onde se situam os complexos agroindustriais de cana-de-açúcar, fumo, aves e suínos.

Em 1985, ano em que as políticas e os recursos de crédito para investimento já haviam declinado bastante no País, a intensidade de exploração da terra, associada ao uso de mão-de-obra familiar e tração animal volta a ser o fator mais importante (F1 1985) seguido do uso de capital financeiro próprio de longo prazo (F2 1985), uso de capital financeiro de terceiros de curto prazo (F3 1985) e do uso de insumos modernos (F4 1985). Três microrregiões apresentaram os quatro fatores positivos simultaneamente: MRH Litoral Sul Catarinense (301), região produtora de fumo, MRH Colonial do Rio do Peixe (305) e MRH Colonial do Oeste Catarinense (306) regiões das agroindústrias de aves e suínos e de grãos como o milho e a soja. 


\section{CONCLUSÕES}

O processo de colonização do Estado de Santa Catarina constituiu-se basicamente de contingentes de imigrantes europeus ou de seus descendentes. Estes ocuparam a terra em pequenos lotes e na condição de proprietários, introduzindo a produção diversificada associada com as pequenas criações, principalmente de suínos, voltadas para o mercado interno e o auto-consumo. Esta forma de ocupação parece ter sido o principal fator a conduzir o Estado a apresentar uma distribuição menos desigual da posse da terra, quando comparado a outras regiões brasileiras.

Por sua vez, como uma exceção no Estado, a colonização do Planalto catarinense, a partir de migrantes oriundos do Estado de São Paulo, se apresentou associada à produção extensiva de bovinos e à concessão de sesmarias, que até 1822 eram a forma legal de ocupação das terras no País, originando as grandes propriedades catarinenses.

O pessoal ocupado na agricultura foi crescente no período todo como uma conseqüência do próprio crescimento da população, do crescimento econômico, da criação de novos municípios e do processo migratório com a expansão da 
fronteira agrícola do Estado. As terras de boa fertilidade, localizadas na Bacia do rio Uruguai, e as agroindústrias de carnes ali instaladas fizeram com que 0 pessoal ocupado que estava em maior número no início do século no Litoral, passasse a se localizar na região Oeste, indicando que fatores como os recursos naturais associados aos sócio-econômicos conduziram ao deslocamento e à concentração da população nesta região.

A mão-de-obra familiar se apresentou sempre como o principal componente da mão-de-obra rural, embora tenha mostrado um leve declínio acompanhado do aumento do emprego temporário e permanente no Estado todo. Esta característica da agricultura catarinense a distinguiu da agricultura de outras regiões.

As políticas voltadas à modernização da agricultura catarinense, no período todo, não diferiram daquelas adotadas para o resto do País. Porém, pode-se considerar que as políticas implementadas antes da década de 60 foram bem menos intensas e não conduziram a mudanças radicais no setor, tais como as resultantes do pacote tecnológico adotado em meados da década de 60. Ocrédito rural subsidiado, foi, sem dúvida, a principal política de modernização adotada em todo o período do estudo. Em Santa Catarina os maiores estímulos do crédito foram destinados às agroindústrias, que o utilizaram na viabilização de contratos com os pequenos produtores, destacadamente nos setores de avicultura e suinocultura.

Entretanto, os resultados do estudo mostraram que os efeitos das políticas do período analisado na agricultura catarinense foram diferentes dos obtidos para outros Estados brasileiros. Em todo o período houve uma clara predominância do uso de tecnologia tradicional: a intensidade de exploração da terra, quase sempre associada ao uso da força animal, mão-de-obra familiar e pastagens plantadas, foi o principal fator, com exceção do ano de 1980, na explicação das transformações 
pelas quais passou a agricultura catarinense. Esta tecnologia tradicional, em 1920, incluía o beneficiamento dos produtos agropecuários, estando limitada às regiões litorâneas ou próximas ao Litoral. Em 1950, a adoção de tecnologia tradicional se expandiu para outras regiões do Estado.

A política de crédito subsidiado no Estado, no período 1975-80, esteve mais intimamente ligada à produção animal do que à produção vegetal. O uso de crédito rural na produção animal foi o segundo fator mais importante em 1975 e o primeiro em 1980. Este mesmo fator deixa de ter importância em 1985, refletindo a diminuição do crédito rural disponível para a agricultura.

$\mathrm{O}$ uso de tecnologia moderna na produção vegetal esteve presente nos quatro últimos anos do período analisado, apesar de aparecer como um fator de pouca importância na agricultura do Estado. Parte da explicação para este resultado pode estar relacionada ao tipo de solo e relevo existentes em grande parte das propriedades catarinenses, considerados limitantes para o uso da tração mecânica.

$\mathrm{O}$ fato de termos as pequenas propriedades e a mão-de-obra familiar como os principais elementos da agricultura catarinense, não impediu o Estado de se modernizar em certas regiões e setores como o de avicultura, suinocultura, fumo e açúcar ligados às agroindústrias, o que também foi constatado em outros estudos. Porém, as maiores propriedades são destinadas principalmente à produção extensiva de bovinos, consideradas não modernizadas, indicando transformações heterogêneas no Estado.

A modernização teria, entretanto, sido parcial e dependente da agroindústria, não contribuindo, em muitos casos, para a sustentabilidade da pequena produção através dos anos. As recentes migrações de milhares de pequenos produtores do Oeste Catarinense mostram a falta de preparo dos mesmos para enfrentar as novas regras de abertura do mercado brasileiro. $\mathrm{O}$ 
mesmo fenômeno ocorre em outras regiões, como por exemplo o dos pequenos produtores de leite de diversas partes do País.

Do desenvolvimento parcial da pequena produção, não especificamente relacionado às agroindústrias, também pode ter resultado um dos maiores problemas ambientais enfrentados pela agricultura catarinense, que são os resíduos produzidos pela suinocultura. Entretanto, este não é um problema exclusivo da agricultura catarinense.

Portanto, sugere-se que os estudos e as políticas de desenvolvimento devam considerar e avaliar os reflexos que a modernização relacionada aos complexos agroindustriais vem trazendo aos produtores e ao Estado de Santa Catarina, sob o ponto de vista sócio-econômico e dos recursos naturais, com vistas ao destino de recursos. Os efeitos das políticas econômicas, desde o início do Plano Real, sobre alguns setores agroindustriais do Estado vem contribuindo para dificultar ainda mais a relação da agroindústria com os pequenos produtores.

A qualidade dos recursos naturais existentes no Estado e o tamanho das propriedades também devem ser avaliados na busca da sua utilização racional, considerando-se o fato de que os recursos são exauríveis, exigindo como no caso dos solos, o uso de insumos químicos. Entretanto, este nem sempre é viável nas pequenas propriedades catarinenses, devido à sua elevada relação custo-benefício.

Como o tamanho da propriedade em si, não é o principal fator limitante da viabilidade e modemização destas propriedades, mas sim a associação de propriedades de pequeno tamanho com recursos naturais de baixa qualidade, verificou-se a necessidade de uma maior intervenção com a adoção de políticas de auxílio. As políticas agrárias que visam aumentar a área dos minifúndios, que já estão sendo implementadas, vêm em parte a solucionar o problema da viabilidade dos estabelecimentos agropecuários de Santa Catarina, devendo haver, também, o prosseguimento dos estudos neste sentido. 


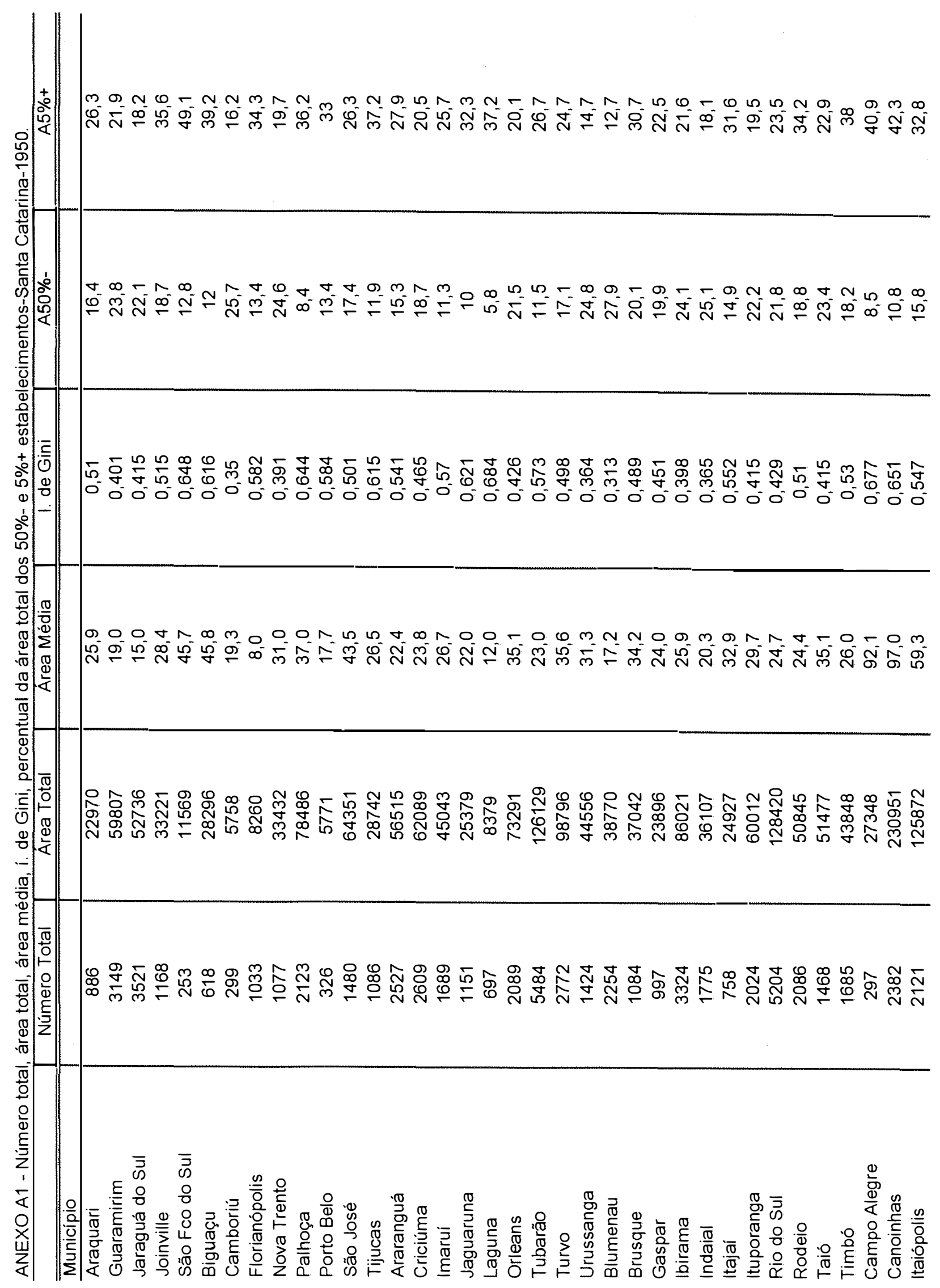




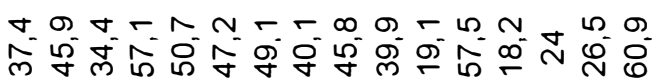

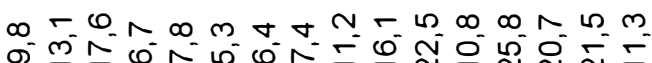

ต

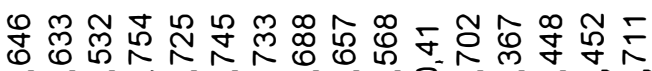

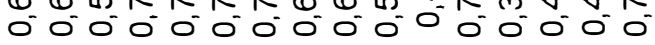

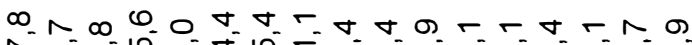

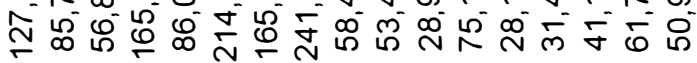

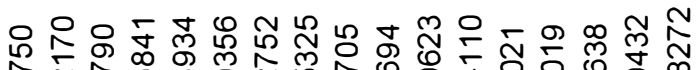

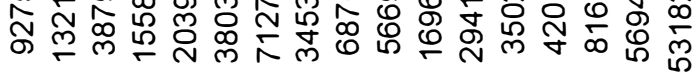

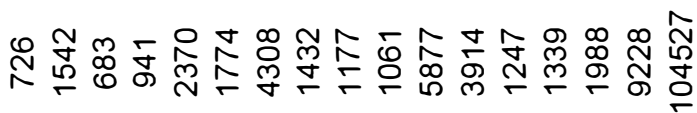

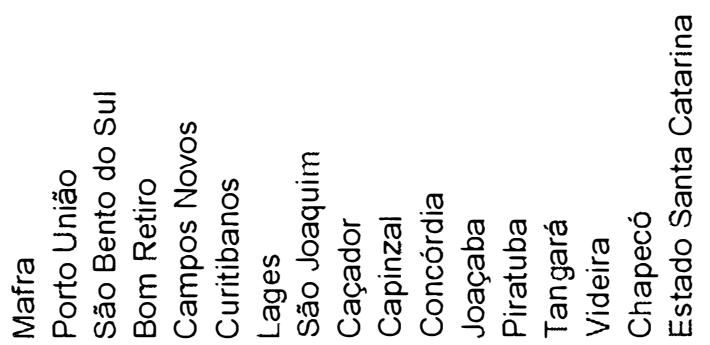




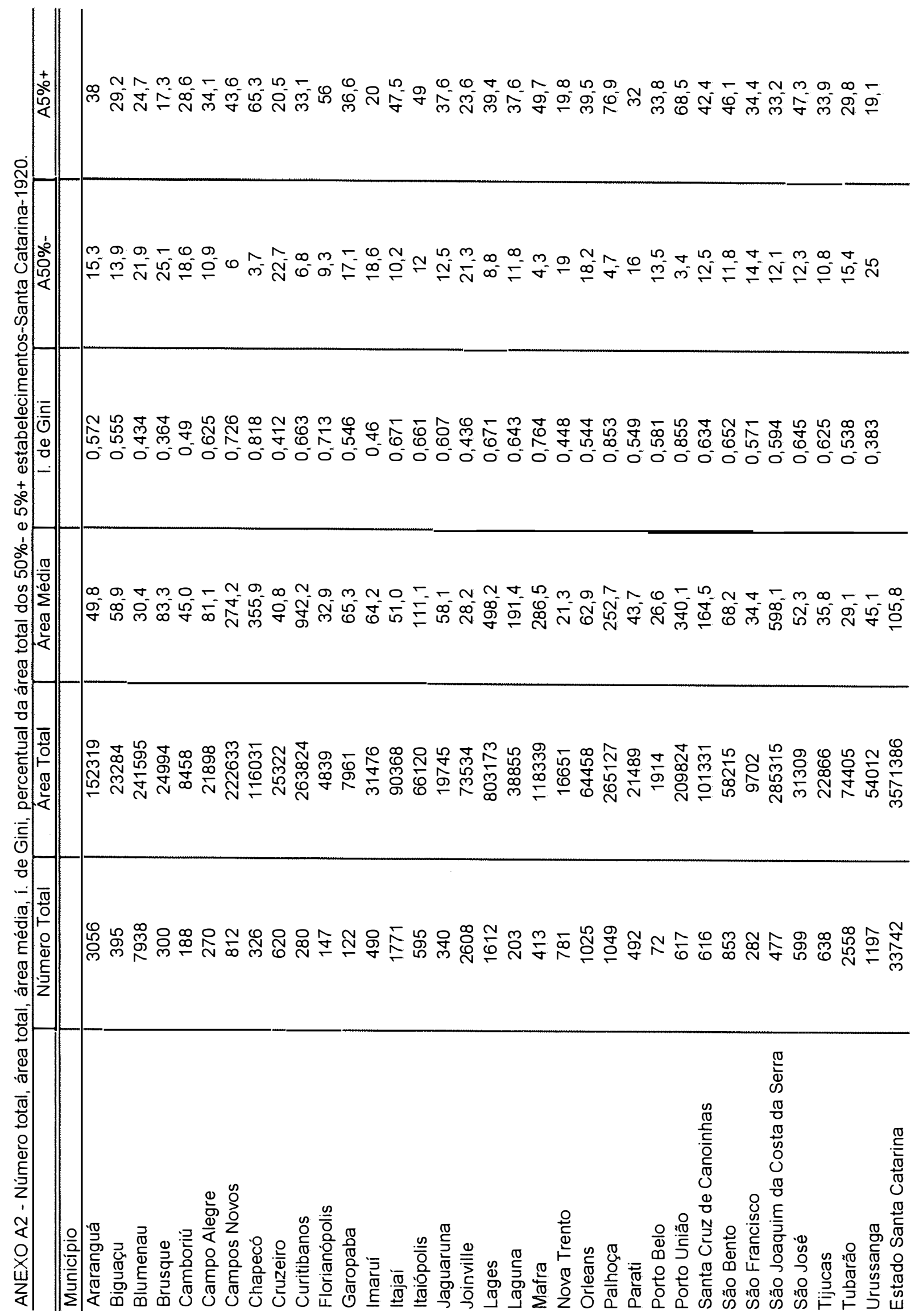




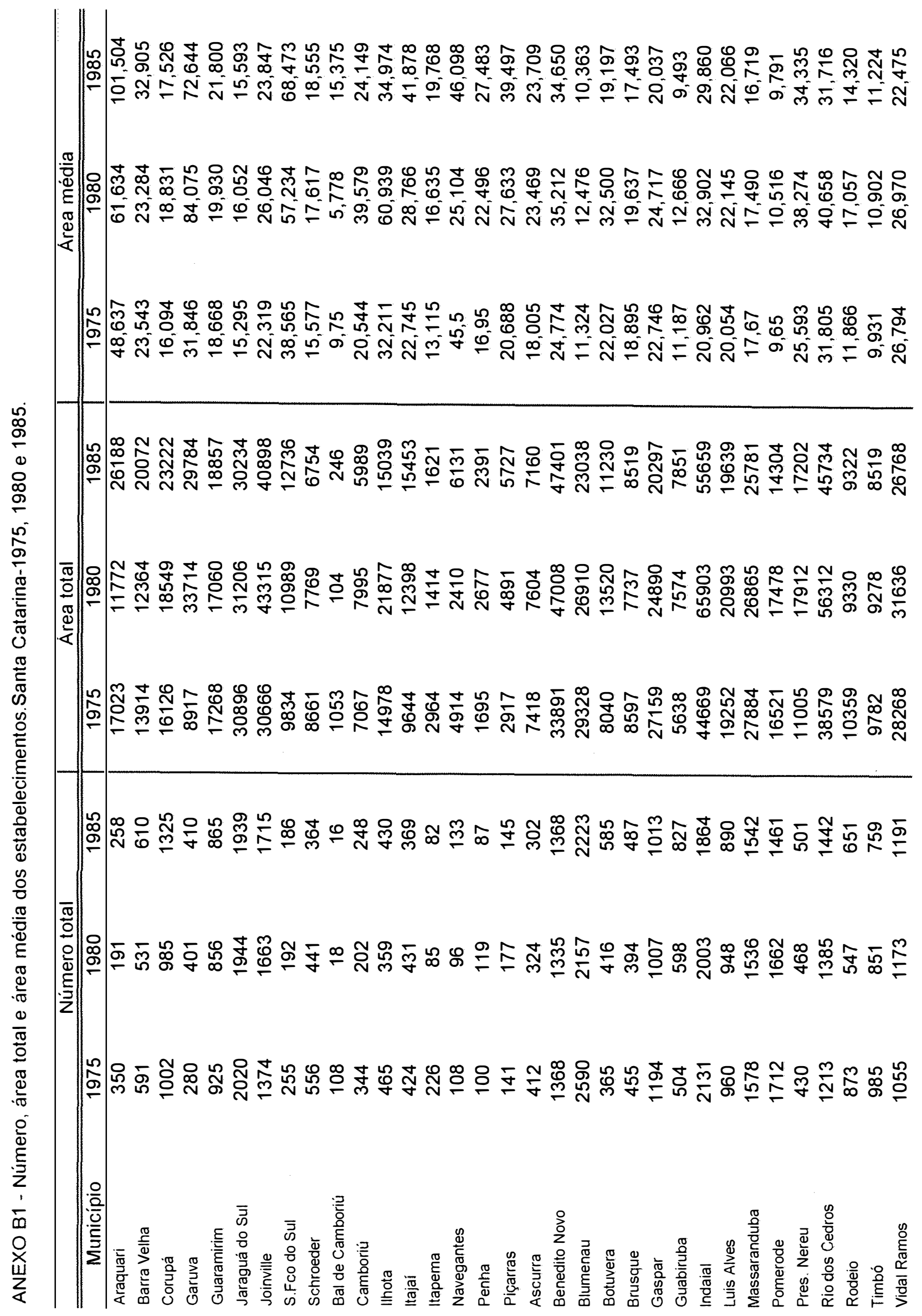




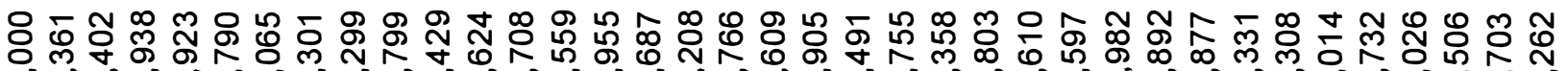
ป N

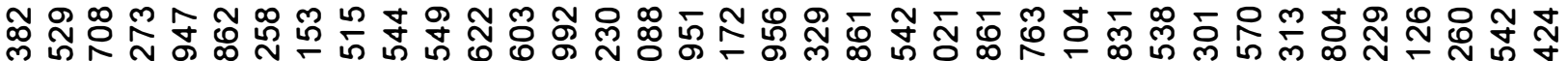
ลี

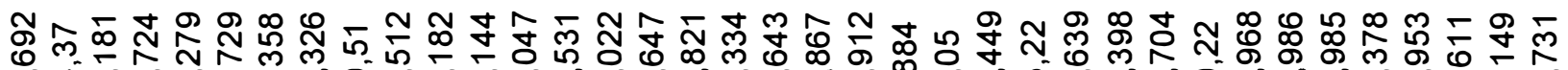

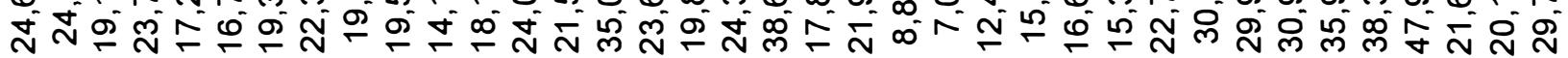

유요

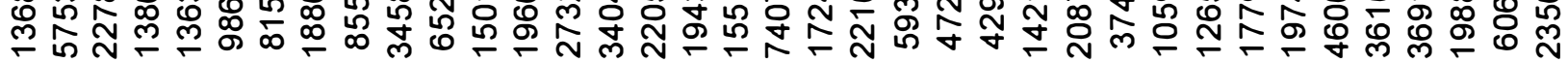

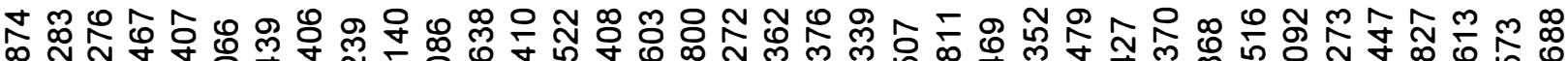

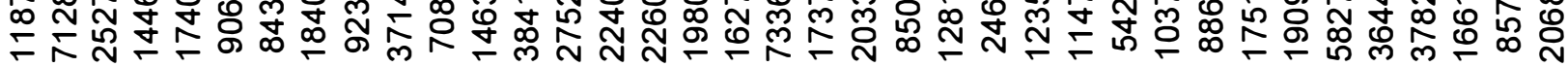

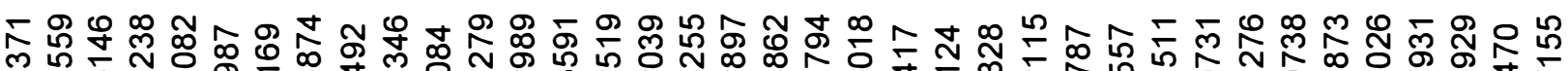

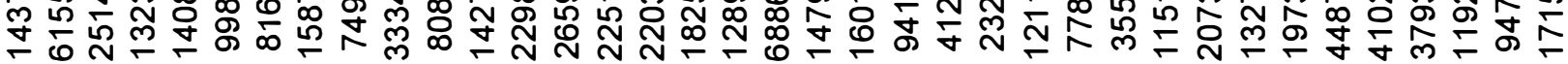

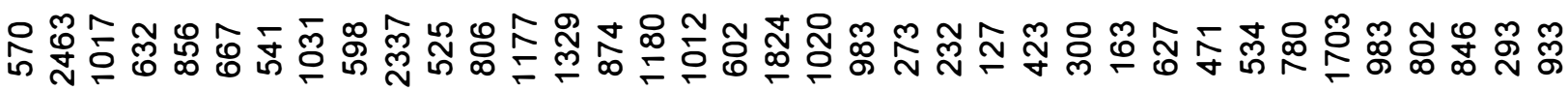

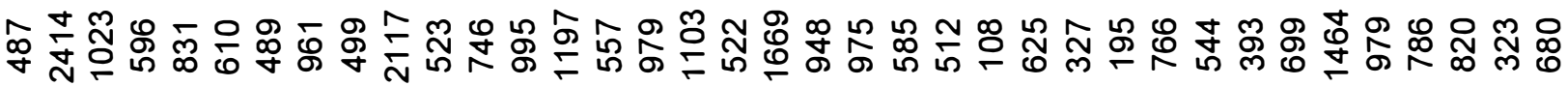

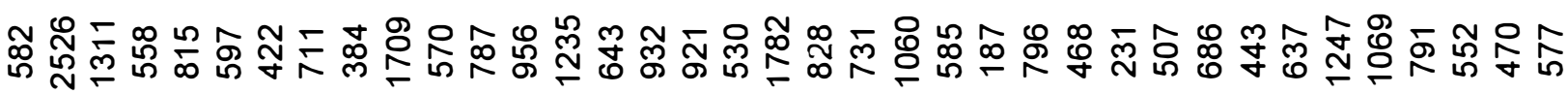

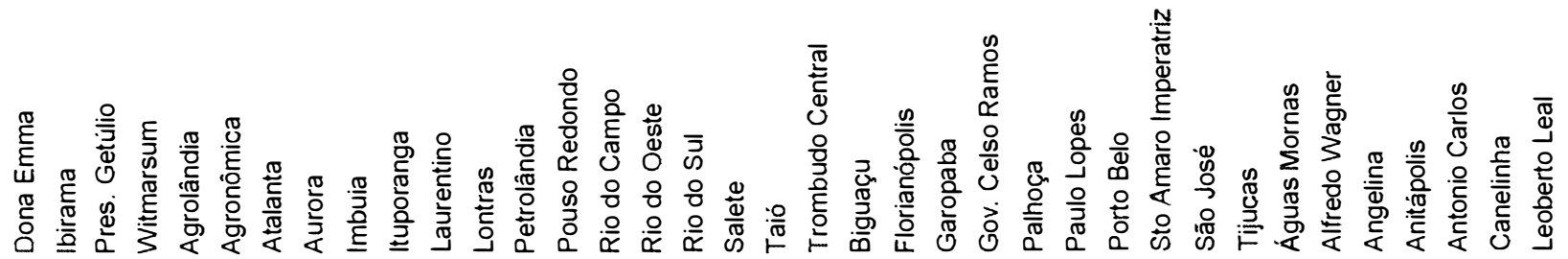




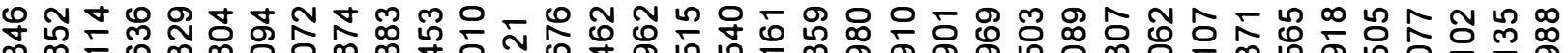
岗

స్ల 尚

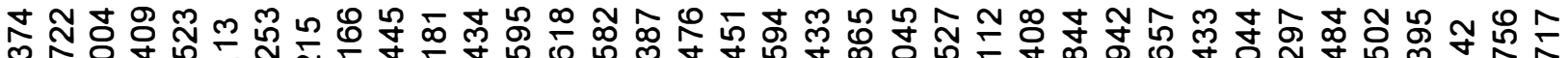
m

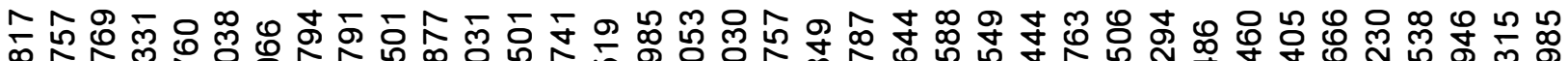

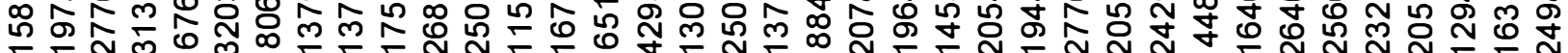

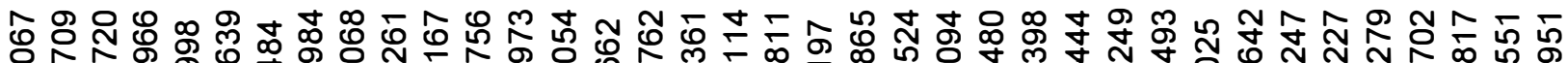

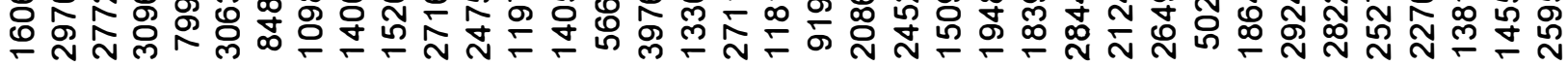

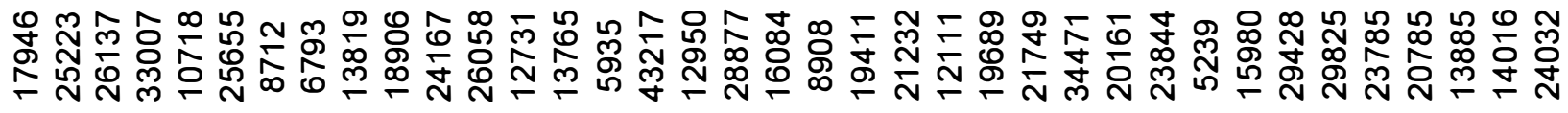

员

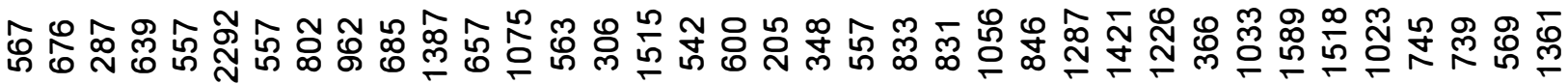

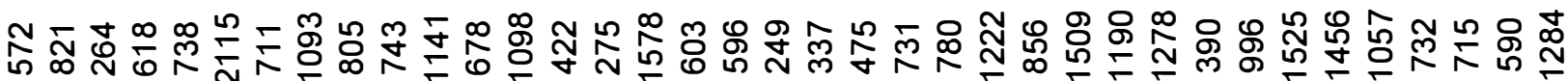

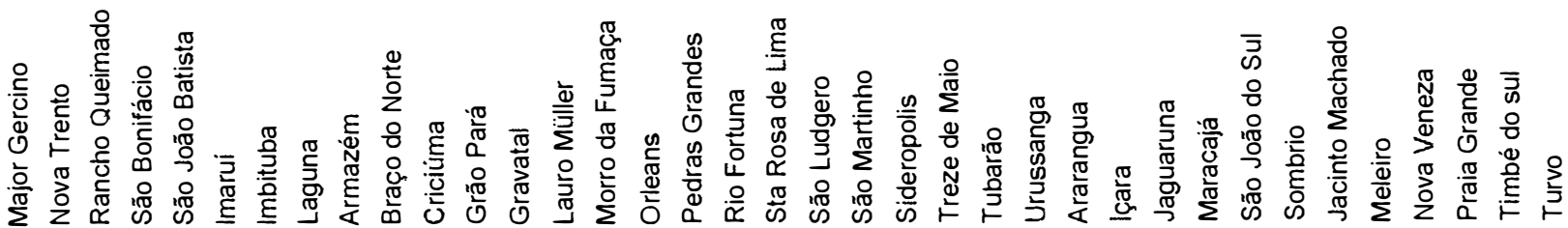




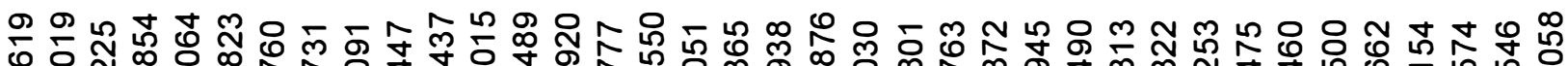

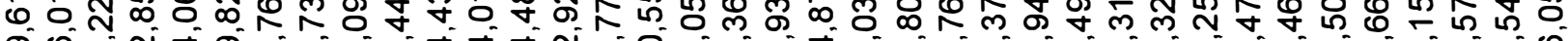
ํำ

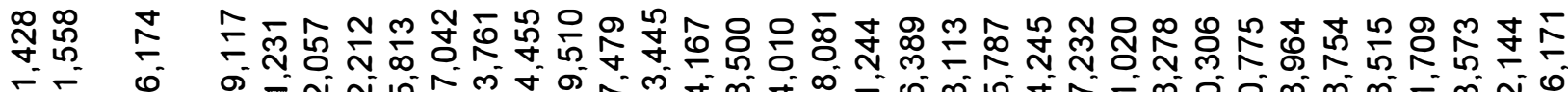

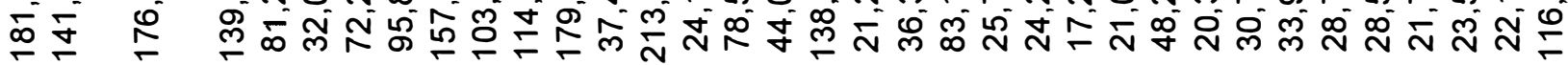

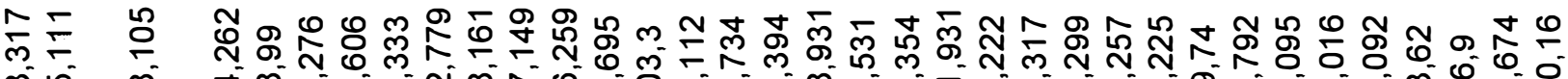
贷

๘

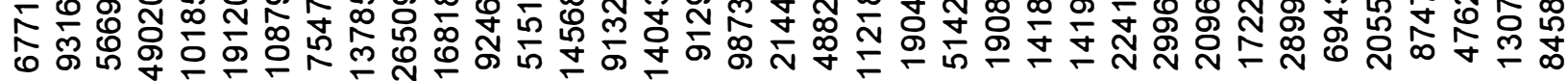

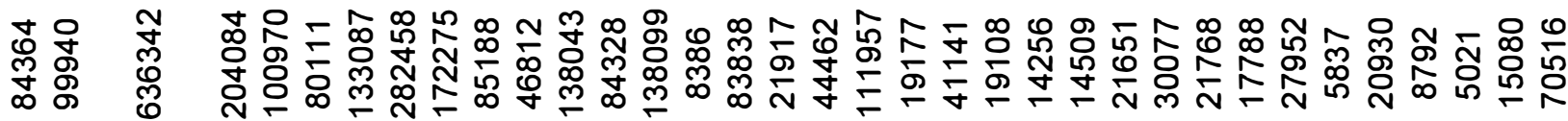

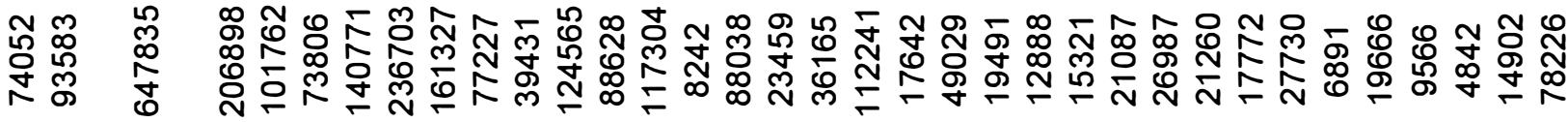

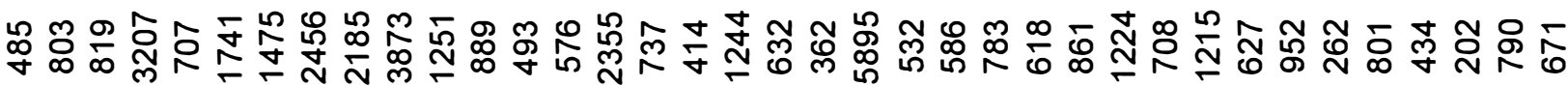

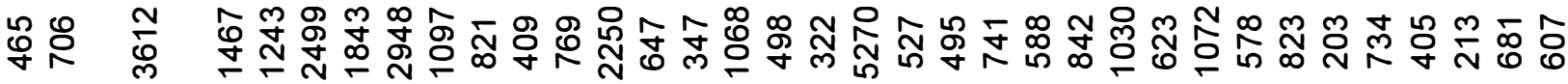

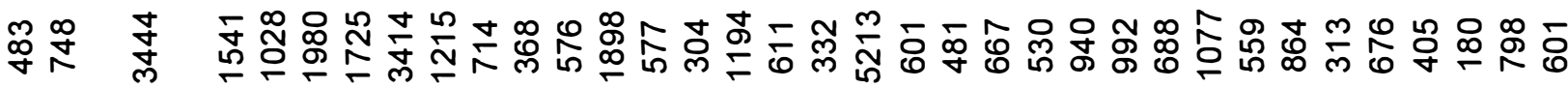

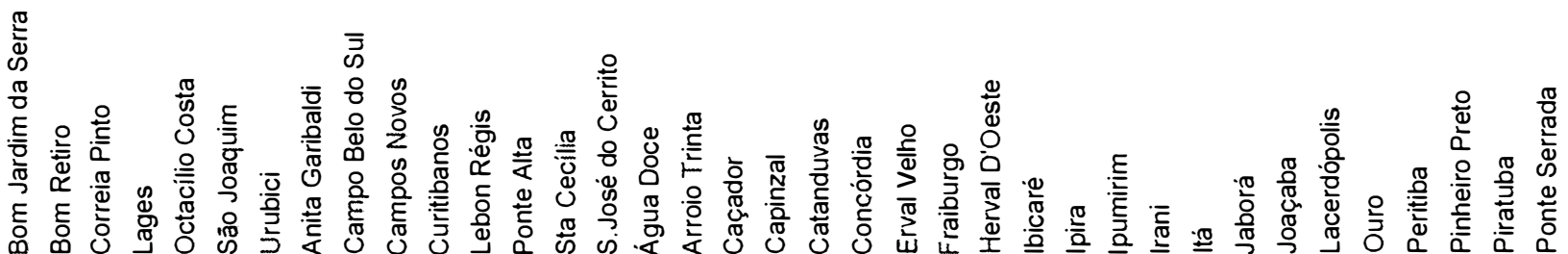


チ莳 ก

品 ลิ่

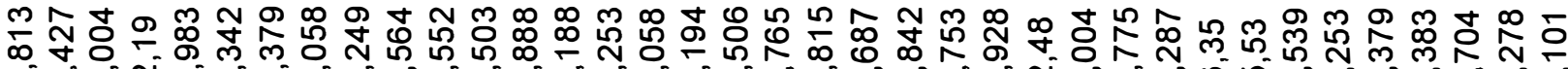

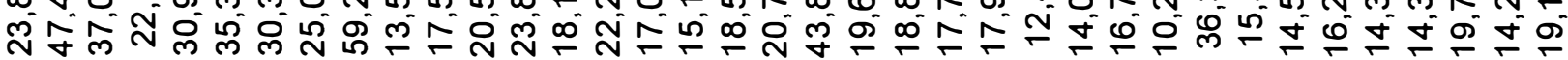

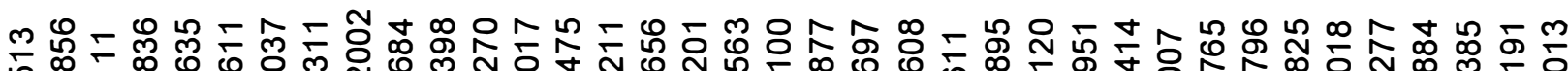

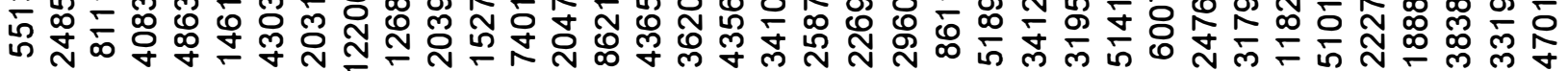

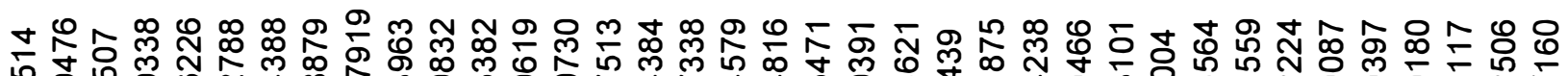
贞声员

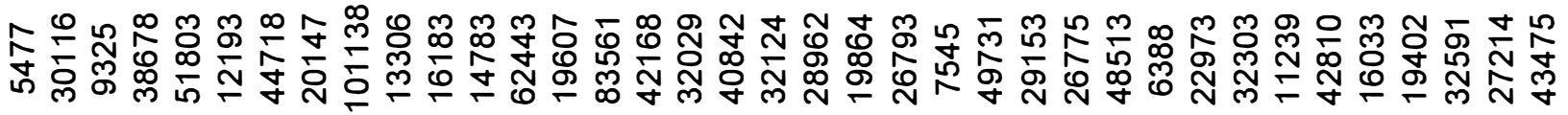

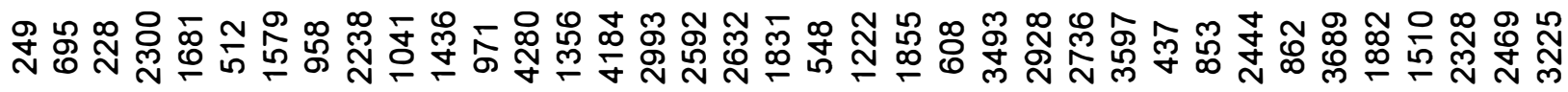

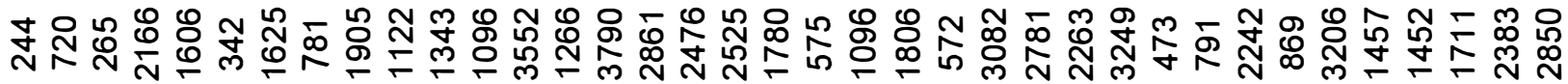

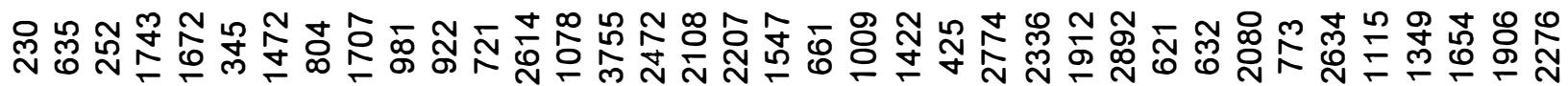

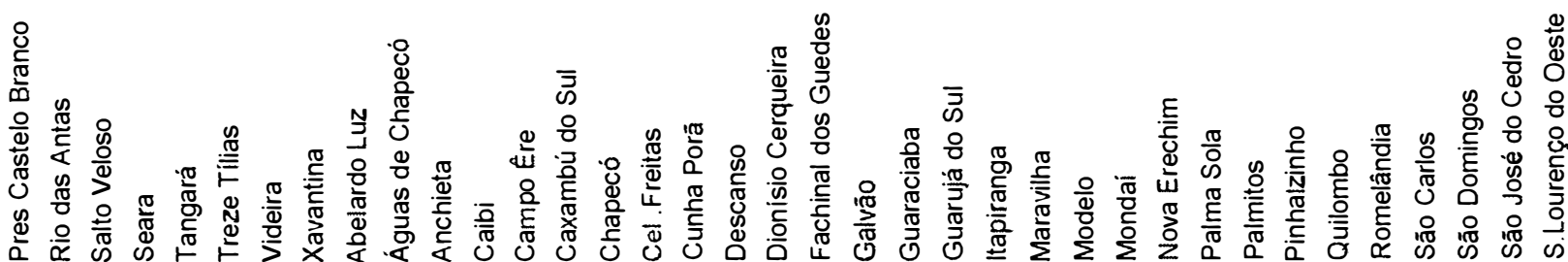




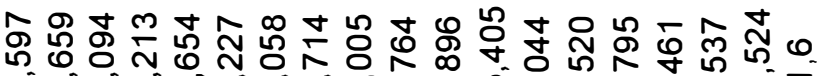

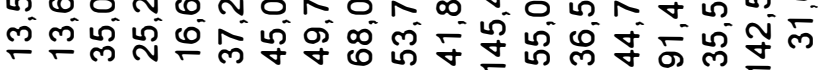

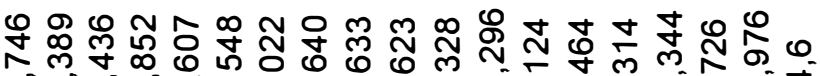

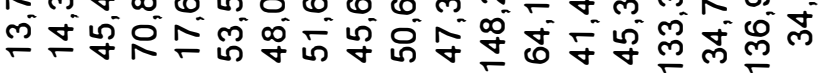

ల్రి

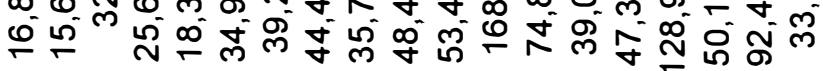

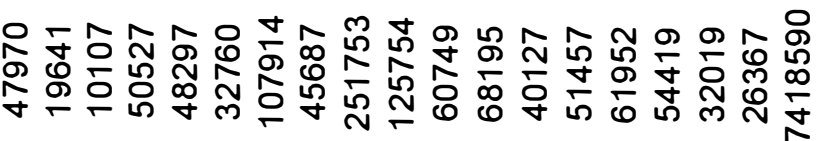

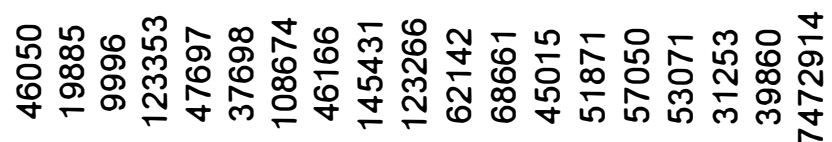

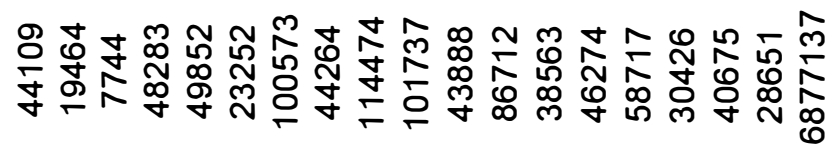

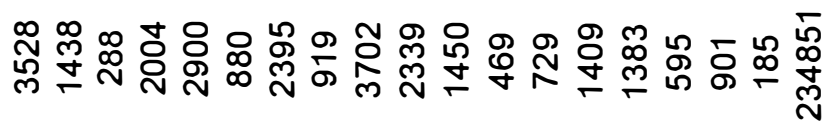

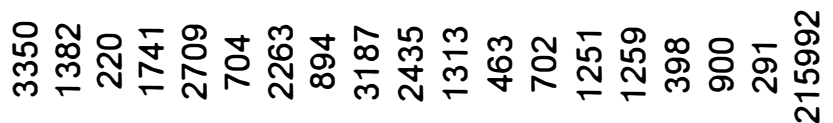

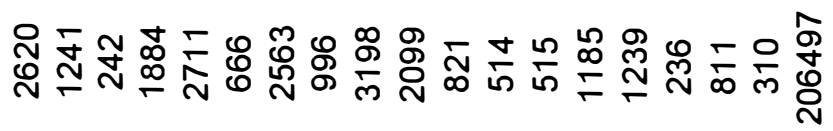

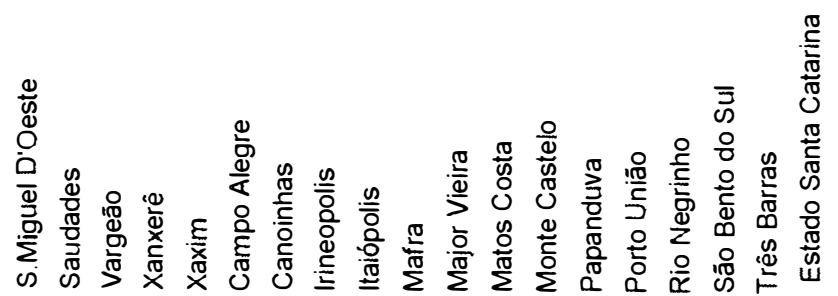




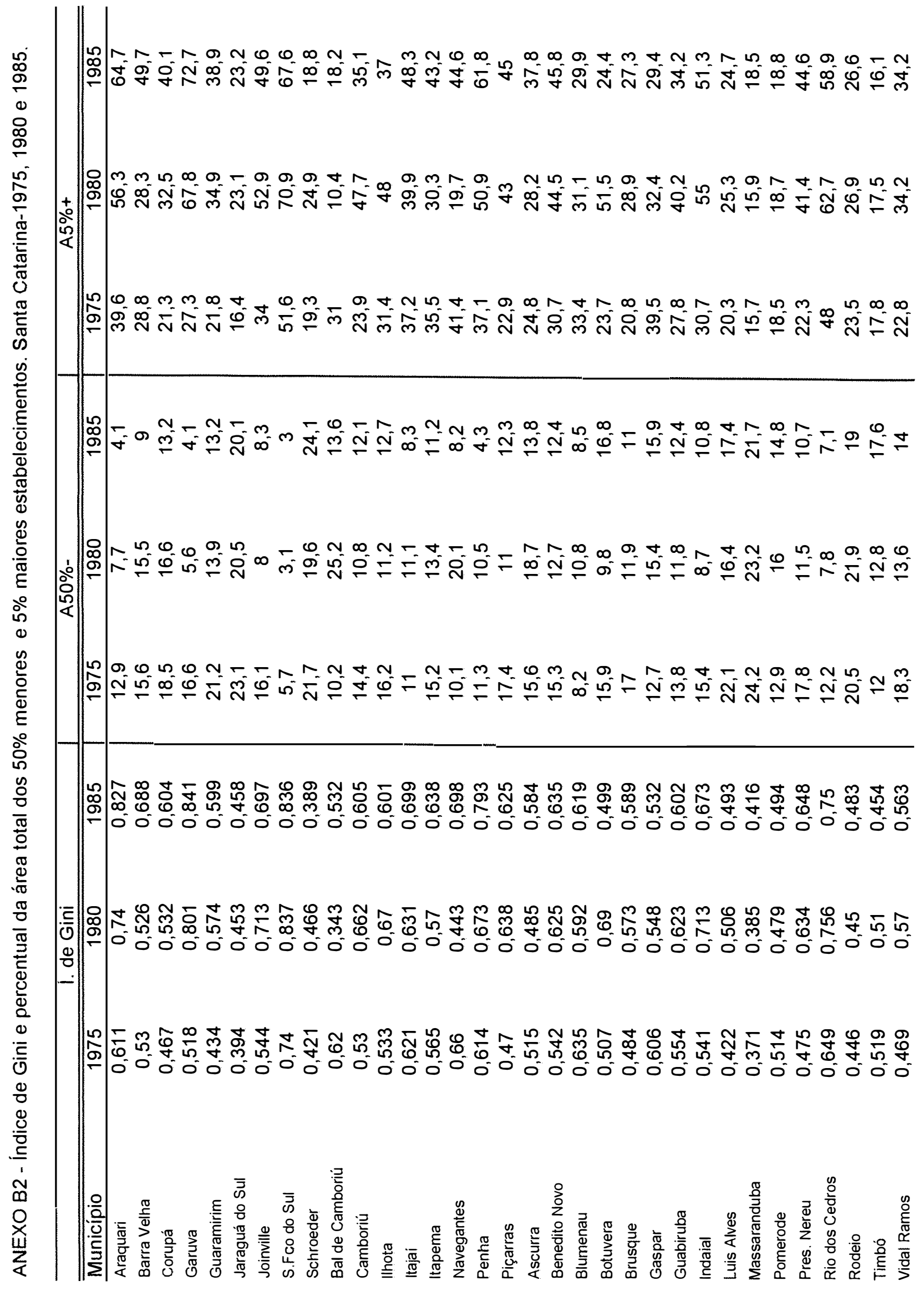




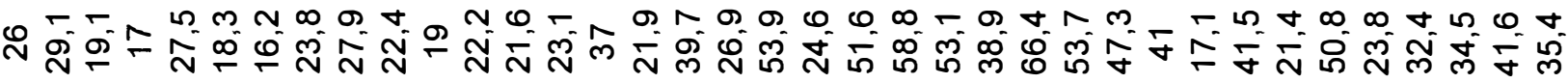

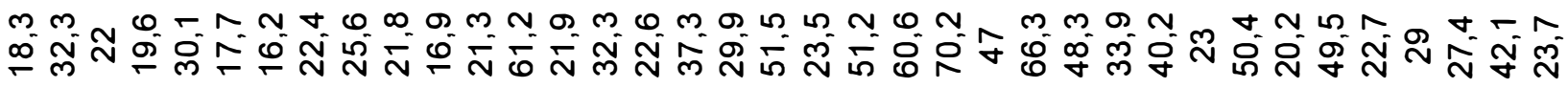

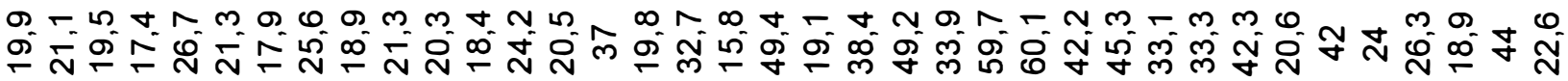

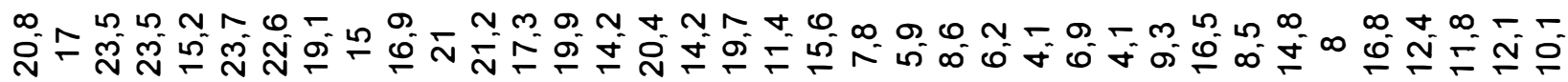

0 m ปัก

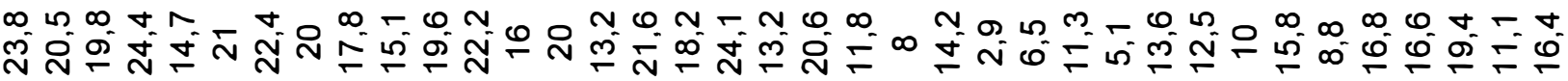

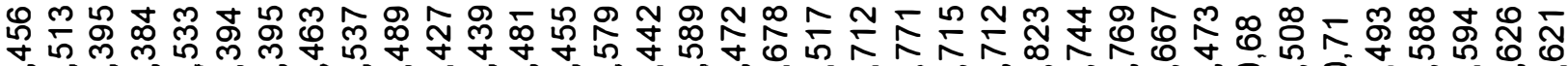

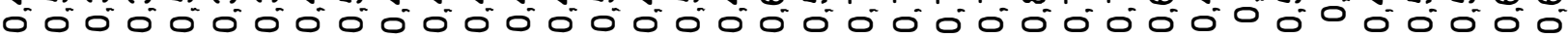

๓ m

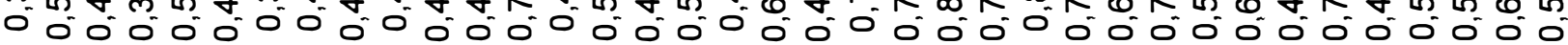

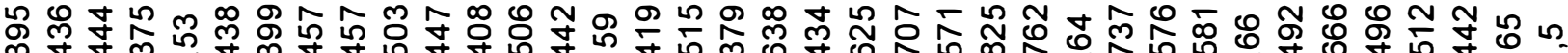

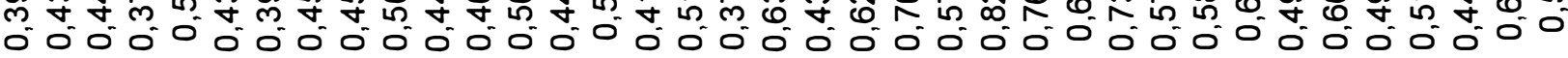

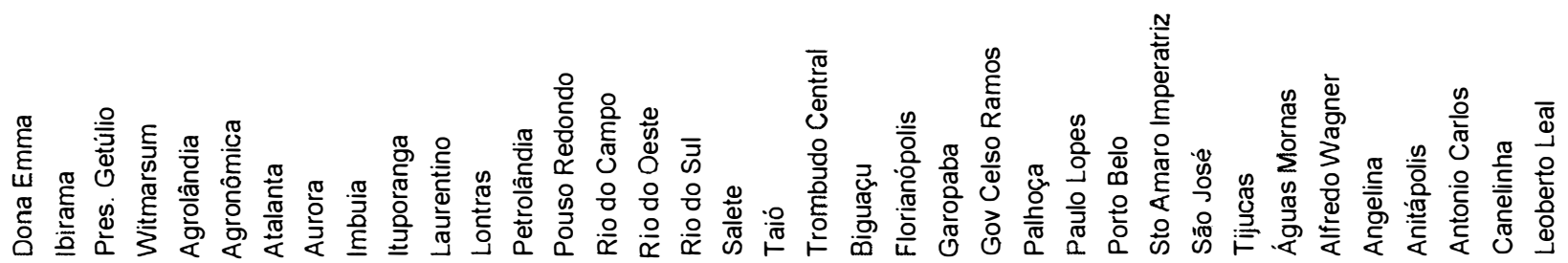


m

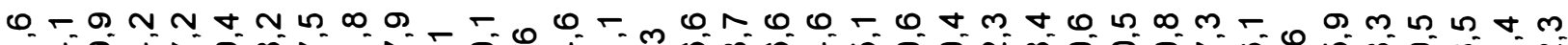

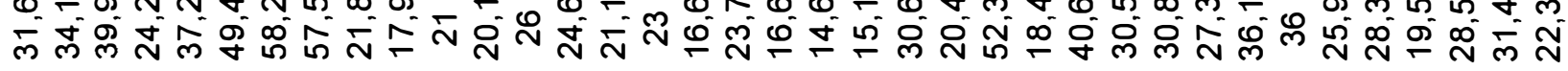

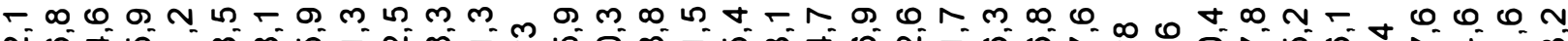

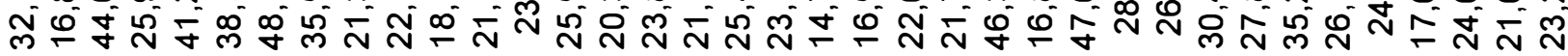

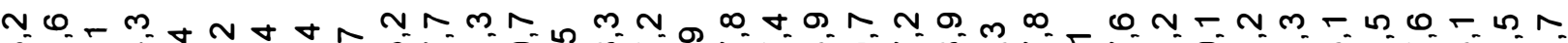

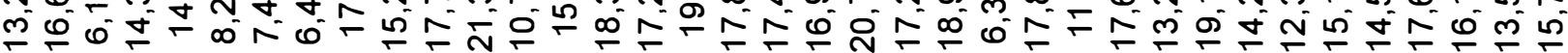

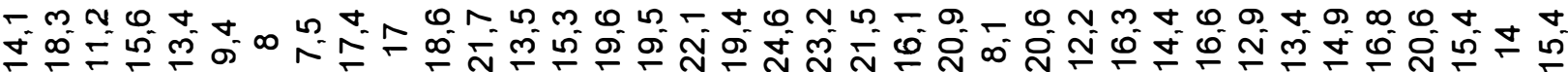

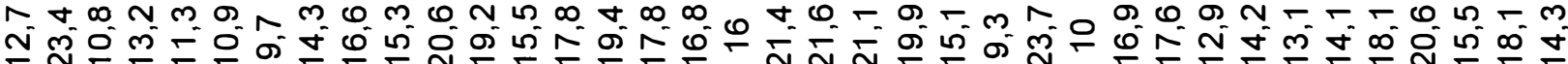

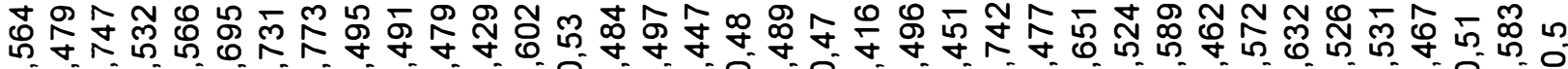

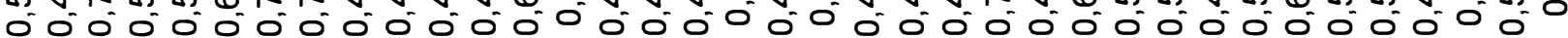

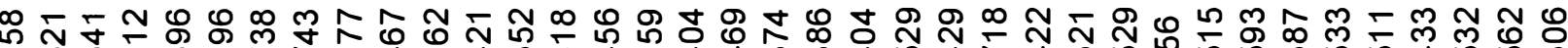
员

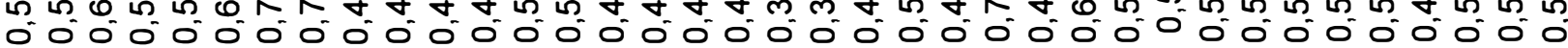

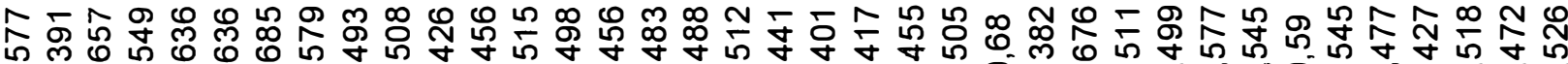

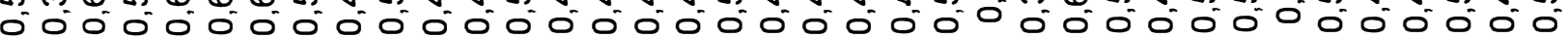

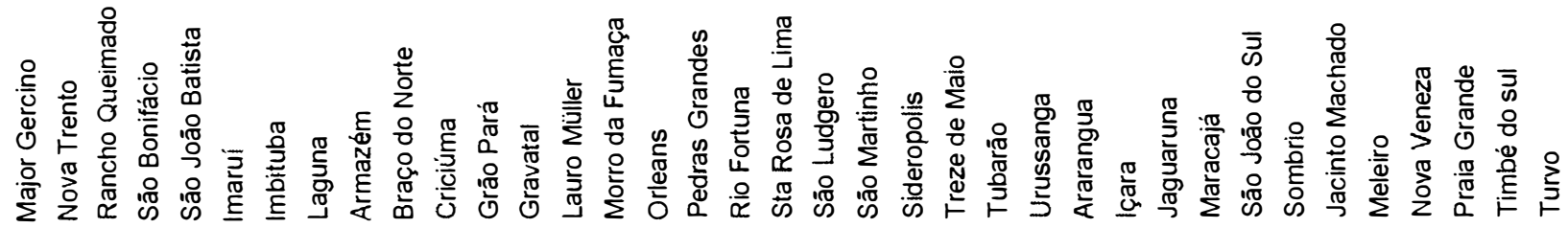




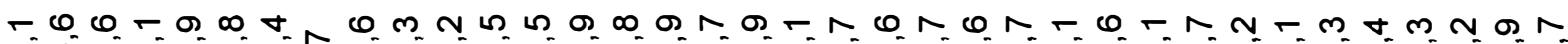
m

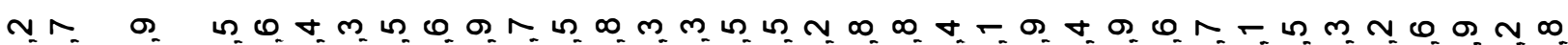

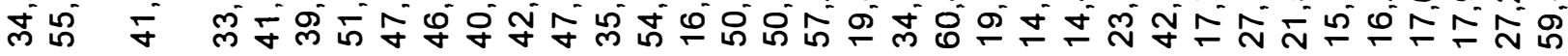

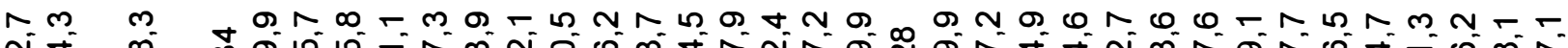
พั

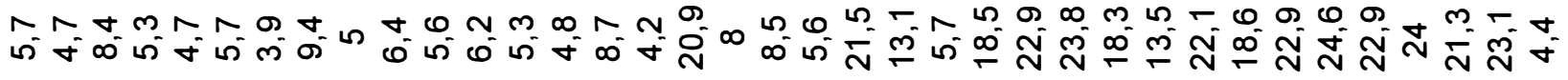

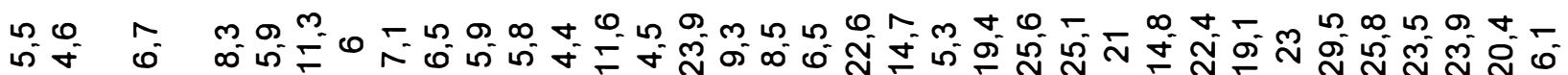

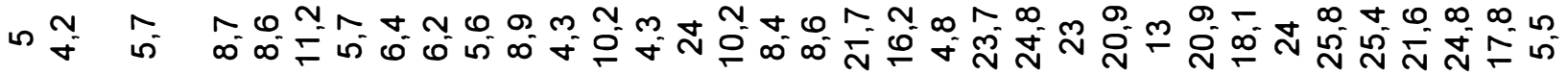

бำ

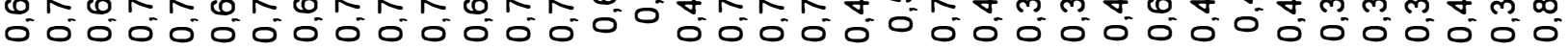

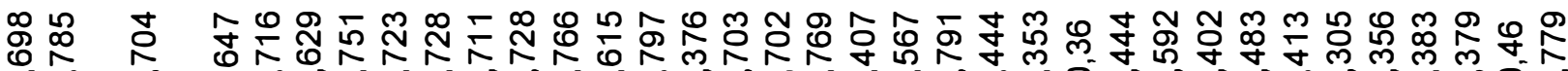

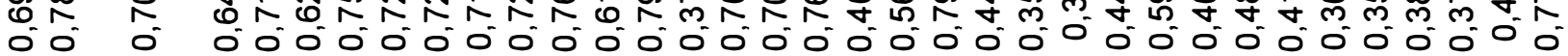

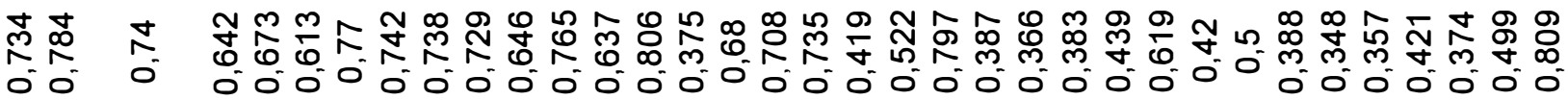

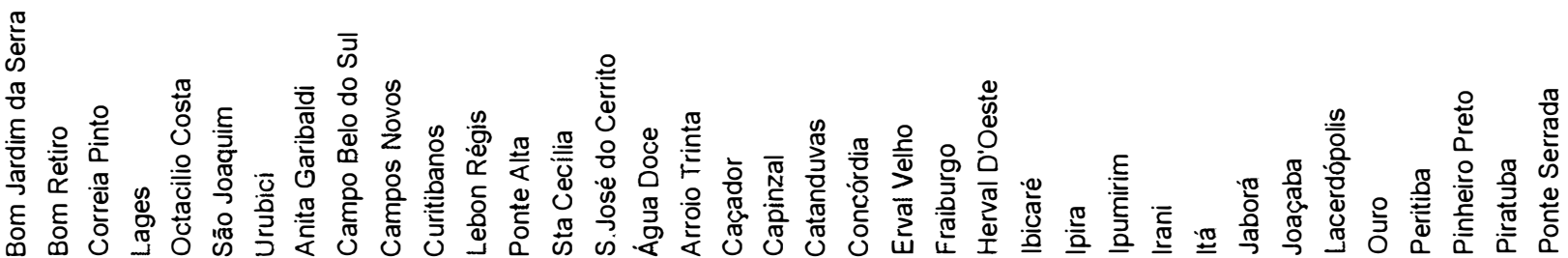




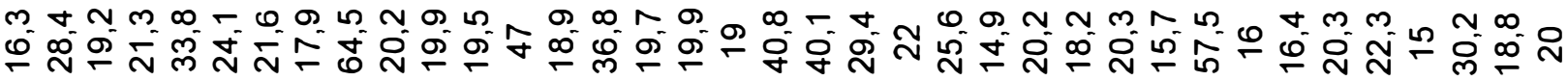

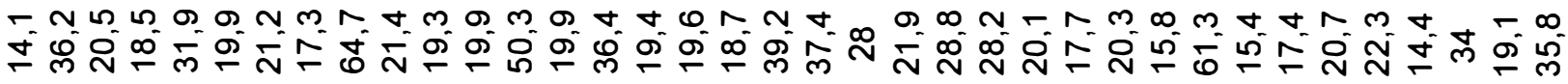

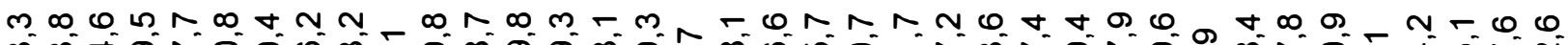
m

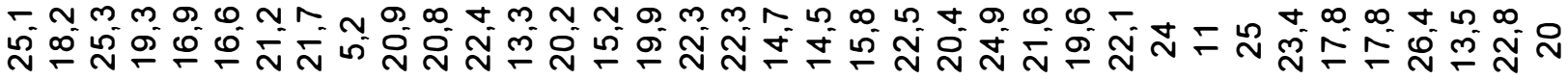

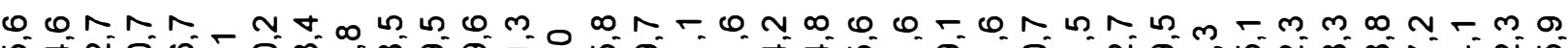

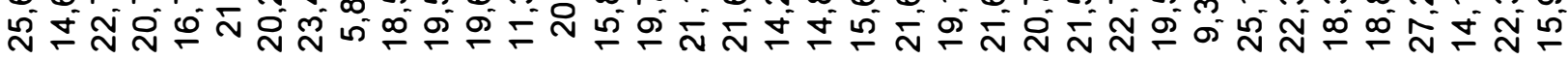

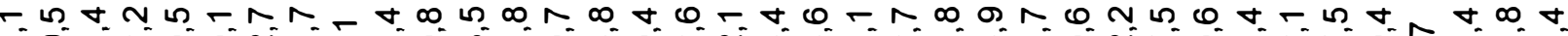

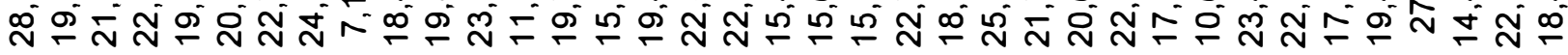

ஜ

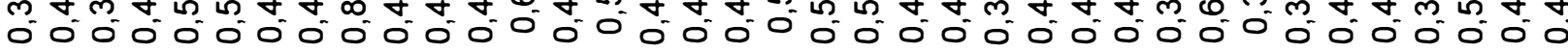

மำ m

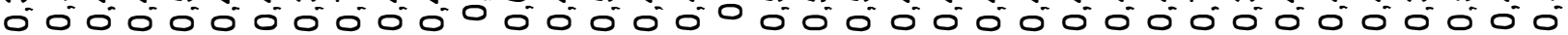

ㅅํㅇำ

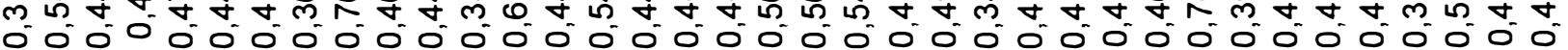

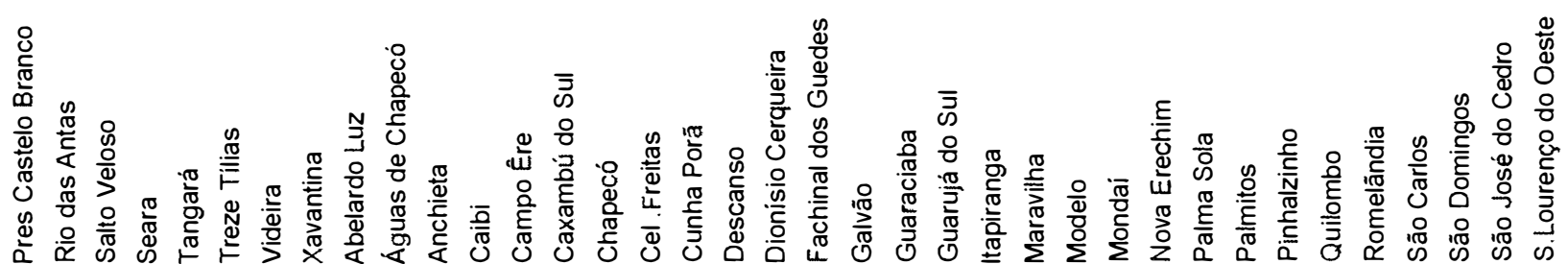




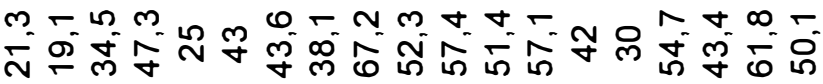

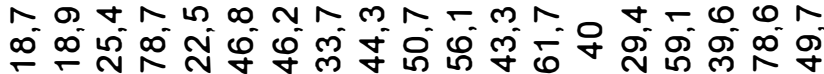

$\infty m-a n a$ m ลิ

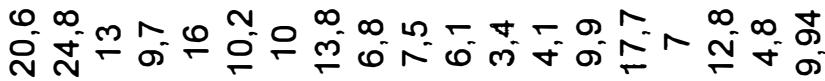

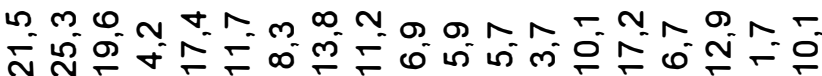

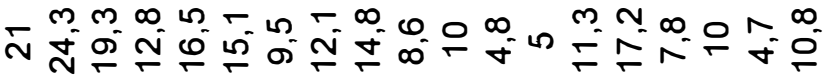

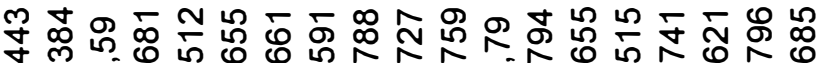

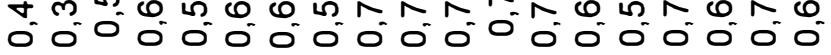

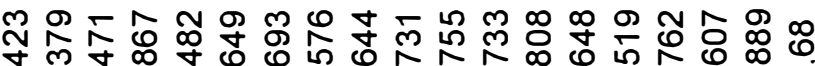

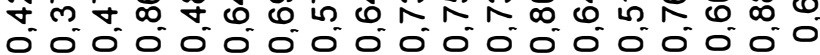

Ұ స్

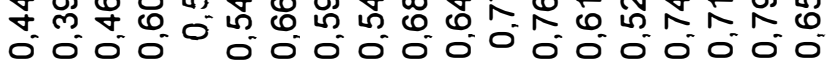

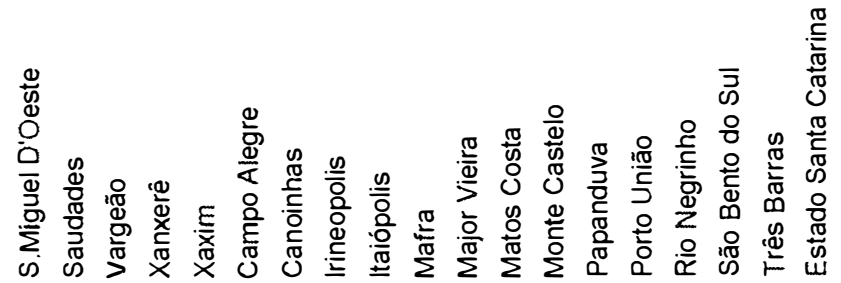




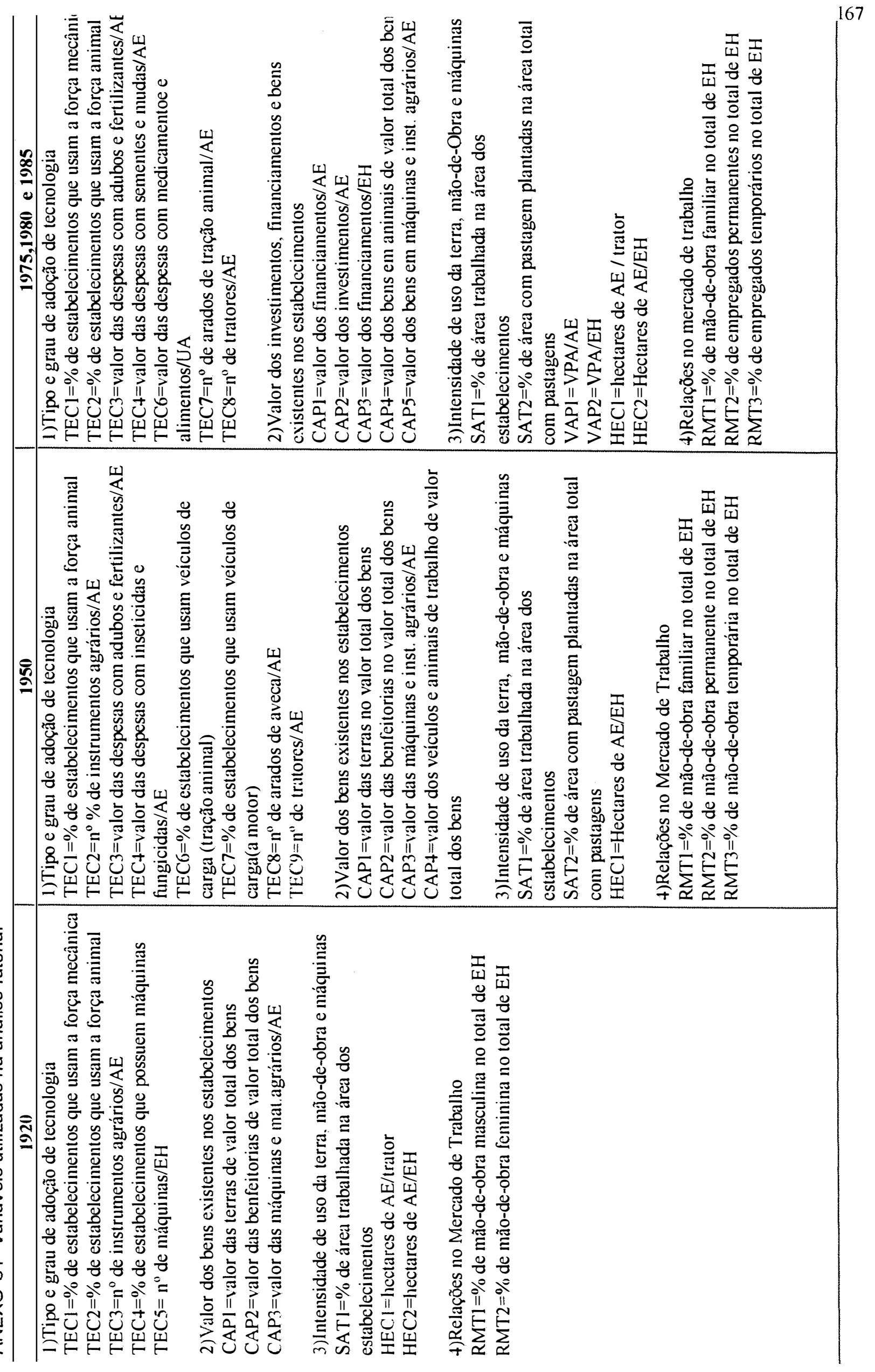


ANEXO C2 - Pessoal ocupado na agricultura. criaçào, caça e pesca em equivalentes-homem. percentual da mào-de-obra masculina e feminina. amiores de 21 anos e menores de 21 anos- Municípios de Santa Catarina - 1920.

\begin{tabular}{|c|c|c|c|c|c|}
\hline Municipios & EHTOTAL & $\begin{array}{l}\text { \% Masculino maior } \\
\text { de } 21 \text { anos }\end{array}$ & $\begin{array}{l}{ }^{\circ} \text { Feminino maior } \\
\text { de } 21 \text { anos }\end{array}$ & $\begin{array}{c}{ }^{\circ} \text { oMaior de } 21 \\
\text { anos }\end{array}$ & $\begin{array}{c}\text { \% Menor de } 21 \\
\text { anos }\end{array}$ \\
\hline Ararangua & 8044,3 & 96,9 & 3,09 & 83,8 & 16.2 \\
\hline Biguaçu் & 4358,7 & 93,3 & 6.68 & 90.5 & 9.50 \\
\hline Blumenau & 17736,3 & 79,6 & 20.4 & 83,2 & 16,8 \\
\hline Brusque & $246+, 9$ & 92,3 & 7.70 & 84.7 & 15.3 \\
\hline Camboriù & 1953.8 & 96,4 & 3.57 & 86,2 & 13,8 \\
\hline Campo Alegre & 1358.9 & 69,2 & 30.8 & 77.4 & 22.6 \\
\hline Campos Novos & 3387,8 & 96,7 & 3.29 & 87,3 & 12.7 \\
\hline Chapeso & 2400.9 & 96,8 & 3,16 & 89,6 & 10,4 \\
\hline Cruzeiro(Joaçaba) & 2853,7 & 92.1 & 7,87 & 89.9 & 10.1 \\
\hline Curitibanos & 2658.6 & 98.5 & 1.45 & 88.7 & 11,3 \\
\hline Florianópolis & 5361,3 & 96.3 & 3.75 & 89.9 & 10,1 \\
\hline Garopaba & 1990.6 & 97,7 & 2.34 & 92,1 & 7,90 \\
\hline Imarui & 2841,6 & 89.3 & 10,7 & 84,4 & 15,6 \\
\hline Itajai & 5906.6 & 98.2 & 1.77 & 91,3 & 8,70 \\
\hline Itaiópolis & 1298,1 & 95,4 & 4.55 & 93,9 & 6,10 \\
\hline Jaguaruna & 1505 & 98.9 & 1.06 & 86,7 & 13.3 \\
\hline Joinville & 9818,1 & 71,4 & 28.6 & 79,5 & 20,5 \\
\hline Lages & 7306,6 & 96.1 & 3.95 & 90,3 & 9,70 \\
\hline Laguna & 5330.6 & 98.3 & 1.66 & 86,2 & 13,8 \\
\hline Mafra & 1920,9 & 95,1 & 4.94 & 88,2 & 11.8 \\
\hline Nova Trento & 1394.3 & 90,7 & 9.35 & 84,5 & 15,5 \\
\hline Orleans & 3174.7 & 95.6 & +.45 & 78.5 & 21,5 \\
\hline Palhof̧a & 6881.2 & 94.3 & 5.67 & 86.6 & 13,4 \\
\hline Parati(Araquari) & 3932.7 & 76.6 & 23.4 & 87.0 & 13,0 \\
\hline Porto Belo & 1513.6 & 98.1 & 1.92 & 87,8 & 12,2 \\
\hline Porto Lnião & 2176.1 & 94.1 & 5.91 & 87.0 & 13.0 \\
\hline Sta Cruz de Canoinhas & 4283.3 & 94.8 & 5.24 & 85,9 & 14,1 \\
\hline São Banto & 1301.5 & 93.4 & 6.57 & 93.2 & 6,80 \\
\hline São Francisco & 3379,2 & 69.7 & 30.3 & 82.1 & 17,9 \\
\hline S.Joaquim da Costa da Serra & 2423.3 & 98.4 & 1.60 & 87.1 & 12,9 \\
\hline São Josẻ & 2846.9 & 97.8 & 2.21 & 92,5 & 7,50 \\
\hline Tijucas & $45+3.6$ & 85.1 & $1+.9$ & 83.1 & 16,9 \\
\hline Tubarão & 8185.5 & 86.2 & 13.8 & 81,9 & 18.1 \\
\hline Urussanga & 2827.5 & 77.2 & 22.9 & 78.2 & 21.8 \\
\hline Estado de Santa Catarina & 139361 & 91.2 & 8.80 & 86.4 & 13,6 \\
\hline
\end{tabular}


ANEXO C 3 - Equivalentes-homem total e percentual do pessoal ocupado na agricultura-Santa Catarina 1950.

\begin{tabular}{|c|c|c|c|c|c|}
\hline Municipios & EHTOTAL & $\% \mathrm{FMSO}^{\circ}$ & $\%$ EP50 & $\% \mathrm{ET} 50$ & $\%$ PARC 50 \\
\hline Araquari & 2703.12 & 88.5 & 1,46 & 7,20 & 2.82 \\
\hline Guaramirim & 8004.68 & 94,2 & 1,25 & 2,17 & 2.38 \\
\hline Jaragua do Sul & 7630.64 & 93.6 & 2,09 & 4,07 & 0,20 \\
\hline Joinville & 3240.64 & 95,2 & 1,85 & 2,65 & 0.32 \\
\hline S.Francisco do Sul & 776.70 & 84.2 & 3.41 & 10.9 & 1.51 \\
\hline Biguaçú & 2150.54 & 83.2 & 2.53 & 9.07 & 5,25 \\
\hline Camboriú & 977.12 & 74.5 & 6.35 & 18.9 & 0.24 \\
\hline Florianópolis & 3316.62 & 68,5 & 4,34 & 17.0 & 10,14 \\
\hline Vova Trento & 2751.56 & 88.0 & 1.13 & 9.99 & 0.83 \\
\hline Palhoça & 6034,46 & 86,6 & 0.86 & 12.5 & 0.03 \\
\hline Porto Belo & 1786,08 & 41.6 & 3,14 & 50.6 & 4,70 \\
\hline São José & 3277,56 & 91.8 & 2,73 & 4.70 & 0,72 \\
\hline Tijucas & 3470 & 70,0 & 4.87 & 18.1 & 7.01 \\
\hline Aranrangua & 7909.48 & 74.2 & 2.77 & 16.1 & 6,94 \\
\hline Criciúma & 6510,48 & 96.9 & 0.97 & 1.57 & 0.59 \\
\hline Imarui & 4217.28 & 83.9 & 1.41 & 12.6 & 2.16 \\
\hline Jaguaruna & 2480.94 & 82.8 & 2.30 & 13.3 & 1,61 \\
\hline Laguna & 1959.72 & 87.6 & 7,55 & 2.58 & 2.24 \\
\hline Orleans & 5262.82 & 95.3 & 0,39 & 3.51 & 0.77 \\
\hline Tubarão & 13775.24 & 84.2 & 1.72 & 11.5 & 2.66 \\
\hline Turvo & 9569,54 & 79.9 & 4.50 & 6,45 & 9.13 \\
\hline Urussanga & 4026.46 & 96.5 & 2.15 & 0.969 & 0.37 \\
\hline Blumenau & 4930.62 & 95.3 & 2.69 & 1,72 & 0.31 \\
\hline Brusque & 2749.4 & 95,5 & 2.31 & 1.56 & 0,61 \\
\hline Gaspar & 2706,78 & 94,5 & 1.37 & 2.36 & 1.81 \\
\hline Ibirama & 7512.82 & 91.5 & 1.55 & 6.35 & 0,61 \\
\hline Indaial & 4397.44 & 92.7 & 1.42 & 4.38 & 1.50 \\
\hline Itajai & 2881,88 & 81.7 & 11,21 & 6.33 & 0,73 \\
\hline Ituporanga & 6589.18 & 83.6 & 1.43 & 14,6 & 0.33 \\
\hline Rio do Sul & 12369.1 & 93.0 & 1,60 & 4,48 & 0,88 \\
\hline Rodeio & 4986.24 & 95.3 & 2.06 & 2.40 & 0,25 \\
\hline Taió & 3207,66 & 94.2 & 2.31 & 3.21 & 0.29 \\
\hline Timbó & 3814.26 & 97.1 & 0.64 & 2.06 & 0.19 \\
\hline Campo Alegre & 879.94 & 67.1 & 13,24 & 18.1 & 1.60 \\
\hline Canoinhas & 7457.1 & 70,3 & 4.98 & 22.2 & 2.55 \\
\hline Itaiópolis & 6106,86 & 80.6 & 1.73 & 16.5 & 1.20 \\
\hline Mafra & 2942.26 & $\vdots 1.6$ & 4,74 & 43.1 & 0.48 \\
\hline Porto União & 4294.26 & 86.7 & 2.26 & 10.4 & 0.72 \\
\hline São Bento do Sul & 1846.56 & 90.2 & 3.28 & 5.96 & 0.52 \\
\hline Bom Retiro & 2810.04 & 74.9 & 4.07 & 17.4 & 3.63 \\
\hline Campos Novos & 5758 & 92.0 & 1.89 & 4.50 & 1.59 \\
\hline Curitibanos & 6275,9 & 62.8 & 4.16 & 32.7 & 0.34 \\
\hline Lages & 11893,38 & 79.5 & 3.04 & 16.4 & 1.06 \\
\hline São Joaquim & 5697.62 & 62.4 & 4,26 & 11.2 & 22.10 \\
\hline Caçador & 3877.54 & 75.8 & 4,50 & 16.5 & 3.20 \\
\hline Capinzal & 3821,92 & 94,4 & 1,77 & 3,38 & 0.47 \\
\hline Concordia & 17129.26 & 95.4 & 1.20 & 1,98 & 1.39 \\
\hline Joaçaba & 10501.44 & 86,7 & 2.17 & 7,19 & 3.98 \\
\hline Piratuba & 3579.5 & 89.7 & 1.68 & 2.21 & 6.37 \\
\hline Tangara & 4042.82 & 77.7 & 1,66 & 16.3 & 4.39 \\
\hline Videira & 5268.3 & 87.1 & 3,68 & 7,73 & 1.54 \\
\hline Chapecó & 24300.98 & 89.7 & 3,19 & 6,77 & 0,35 \\
\hline Santa Catarina & 286460.74 & 85.7 & 2.56 & 9,34 & 2.40 \\
\hline
\end{tabular}


ANEXO D1.Valores dos fatores de modernização nos municípios do Estado de Santa Catarina-1920

$\begin{array}{rrrr}\text { Municipios } & F 1 & F 2 & F 3 \\ 1 & -0.34763 & -0.48119 & 0.19140 \\ 2 & 0.31684 & -0.89042 & 1.49965 \\ 3 & -0.22335 & 1.38272 & 0.24886 \\ 4 & -0.29403 & -0.07780 & 4.89586 \\ 5 & 1.61141 & -0.78799 & -0.18334 \\ 6 & -0.80675 & 1.36791 & -1.17678 \\ 7 & -1.29650 & -0.62696 & -0.64441 \\ 8 & -1.27015 & -0.66099 & -0.59363 \\ 9 & -0.11278 & 0.34575 & -0.66859 \\ 10 & -1.69163 & -0.93600 & -1.36802 \\ 11 & 2.14813 & -1.09136 & -1.22003 \\ 12 & 1.42256 & -1.00362 & 0.15873 \\ 13 & -0.11949 & -0.25937 & 0.00503 \\ 14 & 0.04914 & -0.72269 & 1.29867 \\ 15 & -0.52613 & -0.67755 & 0.79663 \\ 16 & 1.41991 & -0.73064 & 0.79743 \\ 17 & 0.25376 & 1.88369 & -0.37605 \\ 18 & -1.50769 & -0.73337 & -1.07993 \\ 19 & 1.34489 & -1.54033 & -0.38674 \\ 20 & -0.96155 & -0.31041 & -0.55707 \\ 21 & 0.11056 & 0.50333 & 1.72693 \\ 22 & -0.16910 & -0.24314 & -0.33563 \\ 23 & -0.75375 & -0.77881 & 0.63096 \\ 24 & 1.70793 & 0.82589 & -0.55338 \\ 25 & 3.31690 & -0.80871 & -0.96482 \\ 26 & -1.47159 & -0.46728 & -0.75797 \\ 27 & -0.22789 & -0.34698 & -0.27593 \\ 28 & -0.85538 & 0.35803 & 0.23720 \\ 29 & 0.98842 & 1.14141 & -0.59269 \\ 30 & -1.57918 & -0.92146 & -1.13642 \\ 31 & 0.12241 & -0.90468 & 1.44472 \\ 32 & 0.52600 & 0.11368 & 0.12947 \\ 33 & 0.05610 & 0.16668 & -0.37232 \\ 34 & 0.06115 & 1.17812 & 0.40712\end{array}$


ANEXO D2. Valores dos fatores de modernização nos municípios de Santa Catarina-1950

$\begin{array}{rrrrr}\text { Municipios } & F 1 & F 2 & F 3 & F 4 \\ 1 & 0.07976 & 1.76541 & -1.46815 & -0.63260 \\ 2 & 1.49334 & 0.29452 & 0.33887 & 0.42459 \\ 3 & 1.37048 & 0.38013 & 0.54303 & 0.43481 \\ 4 & -0.37035 & 1.96057 & 0.80674 & -0.78410 \\ 5 & -0.46038 & 1.74975 & -1.11817 & -0.14467 \\ 6 & -0.38309 & 1.24702 & -0.63284 & 0.08388 \\ 7 & -1.27575 & 1.83749 & -0.46249 & 0.78795 \\ 8 & -0.73722 & 0.09568 & -1.42649 & 7.02148 \\ 9 & 0.49617 & 0.44281 & -0.75121 & -0.64298 \\ 10 & -0.10711 & 1.08065 & -1.84009 & -0.61569 \\ 11 & -1.50689 & 0.42555 & -0.77599 & 0.65422 \\ 12 & -0.09573 & 0.24517 & -0.81473 & -0.15412 \\ 13 & -1.25618 & 1.30819 & -0.66929 & 2.19366 \\ 14 & -0.27177 & -0.10093 & 0.93061 & 0.25801 \\ 15 & 0.93890 & -0.59815 & 0.63970 & -0.10908 \\ 16 & -0.17928 & 2.13337 & -2.15908 & -0.66891 \\ 17 & 0.18725 & -0.58041 & 0.60213 & 0.23820 \\ 18 & -0.37811 & 0.98305 & 0.36814 & 0.25679 \\ 19 & 1.22492 & -0.00455 & -0.47238 & -0.56803 \\ 20 & 0.58851 & -0.47442 & -0.32495 & 0.79300 \\ 21 & 0.60760 & -0.72527 & 0.50717 & 0.34066 \\ 22 & 0.93532 & 0.13085 & -0.57560 & -0.04968 \\ 23 & 1.30766 & 0.29582 & 1.94567 & 0.96064 \\ 24 & 0.69223 & 0.03646 & -1.29836 & -0.48411 \\ 25 & 0.63980 & 1.22047 & -0.53030 & -0.00895 \\ 26 & 0.55785 & 0.93355 & -0.67797 & 0.24784 \\ 27 & 1.33477 & 0.30670 & -0.18255 & 0.40086 \\ 28 & -1.20435 & 0.39374 & -0.41242 & 3.19938 \\ 29 & 0.35397 & 0.26250 & -1.30916 & -0.27579 \\ 30 & 0.72172 & 0.27706 & -1.02164 & -0.33585 \\ 31 & 0.98702 & -0.02242 & 0.04988 & -0.36473 \\ 32 & 0.95638 & -0.34348 & -1.02614 & 0.02162 \\ 33 & 1.18084 & 0.04525 & 0.15131 & 0.05289 \\ 34 & -3.91346 & 1.92159 & 1.21982 & -0.07139 \\ 35 & -1.91234 & 0.88463 & 0.57169 & -0.49275 \\ 36 & -0.93276 & 1.59984 & -0.05573 & -0.84924 \\ 37 & -3.48782 & 1.72006 & 0.52995 & -0.50613 \\ 38 & -1.01692 & 0.92399 & 0.10065 & -0.84827 \\ 39 & -1.01485 & 2.34600 & 1.30119 & -0.41192 \\ 40 & -1.54285 & -1.41661 & 0.00822 & -0.32515 \\ 41 & 0.51454 & -2.07295 & -0.59065 & -0.50744 \\ 42 & -1.57725 & -1.97136 & -0.91622 & 0.11653 \\ 43 & -0.84005 & -2.18953 & -0.79000 & -0.27844 \\ 44 & -1.45507 & -1.95251 & -0.44290 & -0.13916 \\ 45 & -1.56157 & 0.18328 & 1.05151 & 0.10740 \\ 46 & 0.02291 & -0.25476 & 0.61807 & -0.52764 \\ 47 & 0.81905 & 0.10829 & 0.64543 & -0.42730 \\ 48 & -0.34527 & -0.76909 & 0.27823 & -0.67762 \\ 49 & 0.37193 & 0.10439 & 3.89629 & 0.61940 \\ 50 & -0.34189 & -0.25399 & 1.96533 & -0.00936 \\ 51 & -0.85037 & -0.06141 & 2.53852 & 0.68033 \\ 52 & -0.32293 & -0.21299 & 0.14200 & -0.67449\end{array}$


ANEXO D3.Valores dos fatores de modernização nos municípios do Estado de Santa Catarina-1975

\begin{tabular}{|c|c|c|c|c|}
\hline MUNICIPIOS & F1 1975 & F2 1975 & F3 1975 & F4 1975 \\
\hline 1 & $-0,74216$ & $-0,84384$ & 0,44133 & 2,02559 \\
\hline 2 & $-0,66155$ & $-0,97101$ & 0,76162 & 0,02289 \\
\hline 3 & $-0,80854$ & $-0,2807$ & 0,11139 & $-1,31199$ \\
\hline 4 & $-1,73738$ & $-0,5053$ & $-0,25602$ & $-0,99508$ \\
\hline 5 & $-0,12851$ & $-0,3877$ & 3,58799 & $-0,18761$ \\
\hline 6 & $-0,84266$ & 0,06037 & 0,41133 & $-1,1664$ \\
\hline 7 & $-0,66577$ & $-0,11652$ & 1,49808 & $-0,35453$ \\
\hline 8 & $-1,76713$ & $-0,57038$ & $-0,48367$ & 0,69385 \\
\hline 9 & $-1,30794$ & 1,89086 & 1,41072 & $-0,91598$ \\
\hline 10 & $-1,9285$ & $-0,13287$ & $-0,30917$ & $-1,15513$ \\
\hline 11 & $-1,12882$ & 0,19584 & 0,78897 & $-0,8132$ \\
\hline 12 & $-1,28314$ & $-0,41576$ & 0,20781 & $-0,27287$ \\
\hline 13 & $-1,2459$ & 0,09959 & 0,89452 & $-0,03628$ \\
\hline 14 & $-1,44987$ & $-0,39341$ & $-0,10979$ & $-1,31086$ \\
\hline 15 & $-1,74539$ & 0,09714 & 4,12864 & 1,96221 \\
\hline 16 & $-0,86268$ & $-0,15776$ & 0,27433 & 0,20083 \\
\hline 17 & $-0,90694$ & $-0,62371$ & 1,2781 & $-0,60069$ \\
\hline 18 & $-0,8315$ & $-0,57318$ & 1,59745 & $-1,65245$ \\
\hline 19 & $-1,26709$ & $-0,59864$ & $-0,17533$ & $-1,34364$ \\
\hline 20 & $-1,82867$ & 0,03537 & $-0,46134$ & $-1,26119$ \\
\hline 21 & $-0,73631$ & $-0,65508$ & 0,14405 & $-1,19316$ \\
\hline 22 & $-0,69185$ & $-0,61825$ & 0,3621 & $-0,70491$ \\
\hline 23 & $-1,0233$ & $-0,41028$ & 0,75243 & $-0,89463$ \\
\hline 24 & $-0,67488$ & $-0,97549$ & $-0,02606$ & $-1,55491$ \\
\hline 25 & $-1,41743$ & $-0,23669$ & 0,30595 & $-1,02737$ \\
\hline 26 & $-1,32529$ & $-0,1449$ & $-0,04209$ & $-1,29247$ \\
\hline 27 & $-0,42369$ & $-0,24325$ & 2,68905 & $-0,91954$ \\
\hline 28 & $-1,12004$ & $-0,39884$ & $-0,03789$ & $-1,57192$ \\
\hline 29 & $-0,15109$ & $-0,50286$ & $-0,5586$ & $-0,96409$ \\
\hline 30 & $-1,48198$ & $-0,09667$ & $-0,25622$ & $-0,83021$ \\
\hline 31 & $-0,84136$ & $-0,47659$ & 1,33372 & $-1,68678$ \\
\hline 32 & $-1,01707$ & 0,78305 & 0,97979 & $-1,86943$ \\
\hline 33 & $-0,33198$ & $-0,48709$ & 1,1435 & $-0,57768$ \\
\hline 34 & $-0,02863$ & $-0,38559$ & 0,04188 & $-0,77859$ \\
\hline 35 & $-0,24206$ & $-0,30167$ & 0,38452 & $-0,80538$ \\
\hline 36 & 0,18648 & $-0,47093$ & 1,01094 & $-0,76887$ \\
\hline 37 & 0,14821 & $-0,26046$ & 0,1471 & $-0,82623$ \\
\hline 38 & $-0,50389$ & $-0,42141$ & 1,31491 & $-0,79474$ \\
\hline 39 & $-0,1382$ & $-0,28821$ & 1,89803 & $-1,02622$ \\
\hline 40 & $-0,13105$ & $-0,20004$ & 1,81971 & $-0,98304$ \\
\hline 41 & $-0,28913$ & $-0,83885$ & 0,73265 & $-1,10638$ \\
\hline 42 & $-0,3889$ & $-0,35731$ & 1,98661 & $-0,58797$ \\
\hline 43 & $-0,04363$ & $-0,52906$ & 2,17322 & $-0,87614$ \\
\hline 44 & $-0,37619$ & $-0,25825$ & 1,52199 & $-1,09554$ \\
\hline 45 & $-0,10905$ & $-0,89377$ & $-0,03041$ & $-1,12374$ \\
\hline 46 & $-0,64824$ & $-0,25564$ & 1,55345 & $-0,85695$ \\
\hline 47 & 0,63883 & $-0,65285$ & 2,05425 & 0,43365 \\
\hline 48 & 0,08291 & $-0,63424$ & 0,6847 & $-0,10296$ \\
\hline 49 & $-0,02365$ & $-0,444$ & 1,74213 & $-0,93015$ \\
\hline 50 & $-0,51518$ & $-0,27547$ & 0,15042 & $-0,83806$ \\
\hline
\end{tabular}




\begin{tabular}{|c|c|c|c|c|}
\hline 51 & $-0,38194$ & 0,41956 & 1,36468 & $-1,11599$ \\
\hline 52 & $-0,92754$ & $-0,24749$ & 0,35029 & $-0,53518$ \\
\hline 53 & $-0,54017$ & $-0,40733$ & 1,73673 & $-0,80999$ \\
\hline 54 & $-1,02223$ & 0,37607 & 0,6291 & $-0,23595$ \\
\hline 55 & $-1,40598$ & 0,29496 & $-0,14773$ & $-0,79959$ \\
\hline 56 & $-0,58301$ & $-0,96074$ & $-0,51457$ & $-1,4524$ \\
\hline 57 & $-1,82358$ & $-0,38009$ & $-0,385$ & $-1,1454$ \\
\hline 58 & $-1,37778$ & 0,24355 & 0,14741 & $-0,21846$ \\
\hline 59 & $-1,07994$ & $-0,8437$ & $-1,67231$ & $-1,01514$ \\
\hline 60 & $-1,38348$ & $-0,89845$ & 0,03457 & $-0,71274$ \\
\hline 61 & $-0,39473$ & $-0,94109$ & 0,5659 & $-0,55914$ \\
\hline 62 & $-1,99465$ & 0,18908 & $-0,57863$ & $-1,17956$ \\
\hline 63 & $-0,84112$ & $-0,04759$ & 1,16789 & 0,22529 \\
\hline 64 & $-1,35107$ & $-0,72252$ & $-0,85298$ & $-1,20389$ \\
\hline 65 & $-0,94968$ & $-0,52281$ & 0,09311 & $-0,4295$ \\
\hline 66 & $-1,37373$ & $-0,76674$ & $-0,83249$ & $-1,1826$ \\
\hline 67 & $-1,01153$ & $-1,48063$ & $-2,40787$ & $-0,67294$ \\
\hline 68 & $-0,6815$ & $-0,99922$ & $-0,16639$ & $-1,04465$ \\
\hline 69 & $-0,78784$ & $-0,76854$ & 0,31802 & $-0,3603$ \\
\hline 70 & $-1,44207$ & $-0,68545$ & $-0,6844$ & $-1,26542$ \\
\hline 71 & $-1,24883$ & $-0,66385$ & $-0,45659$ & $-1,08487$ \\
\hline 72 & $-1,14769$ & $-0,99075$ & $-0,87945$ & $-1,34115$ \\
\hline 73 & $-1,4712$ & $-0,754$ & $-1,20259$ & 0,5849 \\
\hline 74 & $-0,57193$ & $-1,13323$ & $-0,80471$ & $-0,77974$ \\
\hline 75 & $-0,41485$ & $-1,01158$ & 1,67203 & $-0,49493$ \\
\hline 76 & $-0,7768$ & $-0,94069$ & $-0,42932$ & $-0,93629$ \\
\hline 77 & $-1,20749$ & $-0,45815$ & $-0,51081$ & $-0,7861$ \\
\hline 78 & $-1,07501$ & $-0,56083$ & $-0,76918$ & $-1,419$ \\
\hline 79 & 0,0078 & $-0,7469$ & $-0,20048$ & $-0,96407$ \\
\hline 80 & 0,43748 & $-0,37859$ & $-0,4923$ & $-0,76162$ \\
\hline 81 & 0,11998 & $-0,38121$ & 1,36284 & $-0,07161$ \\
\hline 82 & 0,04027 & $-0,94322$ & $-1,07866$ & $-0,66967$ \\
\hline 83 & $-0,70203$ & $-0,5685$ & $-0,15981$ & $-1,09238$ \\
\hline 84 & 0,02029 & $-1,05006$ & $-0,57036$ & $-0,82633$ \\
\hline 85 & $-0,10021$ & $-0,92185$ & 1,31189 & $-0,26588$ \\
\hline 86 & $-0,22714$ & $-0,01415$ & 0,1537 & $-0,91115$ \\
\hline 87 & 0,69805 & $-0,97866$ & 0,89856 & $-0,60583$ \\
\hline 88 & $-0,12236$ & $-1,05729$ & $-1,38173$ & $-0,68326$ \\
\hline 89 & $-1,1901$ & $-0,8766$ & $-1,46501$ & $-1,06895$ \\
\hline 90 & 0,32452 & $-0,0168$ & 0,08316 & $-0,35767$ \\
\hline 91 & $-0,43672$ & $-0,90535$ & $-0,71235$ & $-0,93089$ \\
\hline 92 & $-0,13201$ & $-0,89777$ & $-0,48212$ & $-0,5510$ \\
\hline 93 & 0,44899 & $-0,54044$ & 0,93142 & $-1,14967$ \\
\hline 94 & 0,92689 & $-0,90261$ & 1,61296 & 1,10339 \\
\hline 95 & $-0,16642$ & $-0,60245$ & $-0,3532$ & $-0,6096$ \\
\hline 96 & $-0,07356$ & $-0,70637$ & 0,85141 & 0,04275 \\
\hline 97 & 1,01845 & $-1,34192$ & 2,65096 & 0,42402 \\
\hline 98 & $-0,46391$ & 0,20465 & 0,4914 & $-0,68676$ \\
\hline 99 & 0,28724 & $-0,54639$ & 1,09129 & $-1,1576$ \\
\hline 100 & 0,08185 & $-0,97992$ & 1,08906 & $-0,0652$ \\
\hline 101 & $-0,48124$ & $-0,46339$ & 0,48304 & $-0,78615$ \\
\hline 102 & $-0,14612$ & $-0,5267$ & 0,92845 & $-0,75785$ \\
\hline
\end{tabular}




\begin{tabular}{|c|c|c|c|c|}
\hline 103 & 0,75759 & $-0,82388$ & 2,89526 & 0,07223 \\
\hline 104 & 0,059 & $-0,75251$ & 0,99808 & $-0,17146$ \\
\hline 105 & $-0,1464$ & $-0,43745$ & 1,44571 & $-0,28006$ \\
\hline 106 & $-0,42044$ & $-0,51005$ & 0,92586 & $-0,63806$ \\
\hline 107 & 0,86968 & $-0,79549$ & 3,38166 & 0,6435 \\
\hline 108 & $-2,51697$ & $-0,5249$ & $-2,72858$ & 1,59209 \\
\hline 109 & $-0,97636$ & $-0,97691$ & $-0,72856$ & 1,94463 \\
\hline 110 & $-2,42772$ & $-0,39322$ & $-1,27834$ & 1,22145 \\
\hline 111 & $-1,85678$ & $-0,15772$ & $-1,09485$ & 2,0898 \\
\hline 112 & $-1,63344$ & $-0,76126$ & $-1,06534$ & 0,14888 \\
\hline 113 & $-0,54498$ & $-1,25676$ & $-0,9629$ & 0,01958 \\
\hline 114 & $-1,94448$ & $-0,93344$ & $-1,41845$ & $-0,21642$ \\
\hline 115 & $-0,54634$ & $-0,47121$ & $-0,32$ & 1,36 \\
\hline 116 & $-1,76159$ & $-0,59857$ & $-0,62135$ & 1,43556 \\
\hline 117 & $-1,81932$ & $-0,39396$ & $-1,30801$ & $-0,04637$ \\
\hline 118 & $-1,67261$ & $-0,89686$ & $-0,47478$ & 0,94547 \\
\hline 119 & $-1,15824$ & $-1,31544$ & $-1,14732$ & 2,22275 \\
\hline 120 & $-0,97023$ & $-1,24656$ & $-0,61715$ & 0,28192 \\
\hline 121 & $-2,16091$ & 0,02304 & $-1,64211$ & 0,70809 \\
\hline 122 & 0,12239 & 1,81764 & $-0,07116$ & $-0,1807$ \\
\hline 123 & $-0,41169$ & $-0,61284$ & $-0,47203$ & 1,56375 \\
\hline 124 & $-0,26477$ & 0,15502 & $-0,05342$ & 0,94798 \\
\hline 125 & 1,33554 & $-1,67035$ & $-2,77596$ & 2,03311 \\
\hline 126 & $-0,00648$ & 2,43544 & $-0,45541$ & $-0,29374$ \\
\hline 127 & $-0,10492$ & 0,01234 & $-0,58761$ & $-0,23345$ \\
\hline 128 & $-0,40135$ & 0,52887 & 0,30953 & 3,85197 \\
\hline 129 & 0,26399 & 0,38064 & $-0,84988$ & $-0,27057$ \\
\hline 130 & 0,7142 & $-0,08336$ & $-0,43703$ & $-0,66803$ \\
\hline 131 & 0,9831 & $-0,63736$ & $-1,23487$ & $-0,67815$ \\
\hline 132 & $-0,17577$ & 0,98213 & 0,00676 & $-0,2002$ \\
\hline 133 & $-0,28588$ & $-0,1114$ & $-0,62723$ & $-0,39715$ \\
\hline 134 & 0,59951 & $-0,19894$ & $-0,83569$ & $-0,14892$ \\
\hline 135 & $-0,17692$ & 0,39761 & $-0,34939$ & $-0,37734$ \\
\hline 136 & 0,318 & $-0,24908$ & $-0,0834$ & $-0,41626$ \\
\hline 137 & 0,25799 & 0,38359 & $-0,8302$ & $-0,77344$ \\
\hline 138 & $-0,20922$ & 0,11032 & $-0,82062$ & $-0,65121$ \\
\hline 139 & 0,92685 & $-0,30475$ & $-0,64726$ & $-0,55364$ \\
\hline 140 & 0,84398 & 0,93479 & 2,30847 & 0,93171 \\
\hline 141 & 0,46345 & $-0,8576$ & $-1,00019$ & $-0,7652$ \\
\hline 142 & $-1,54091$ & $-0,29977$ & $-1,19596$ & 0,50356 \\
\hline 143 & 1,33211 & $-0,0486$ & $-2,00079$ & $-0,56493$ \\
\hline 144 & $-0,21392$ & 0,02104 & 0,07984 & 0,54568 \\
\hline 145 & $-0,26604$ & 1,37095 & $-0,13058$ & $-0,10452$ \\
\hline 146 & 1,00397 & $-0,03936$ & $-1,17463$ & 0,00784 \\
\hline 147 & $-0,0184$ & $-0,02285$ & $-0,14148$ & $-0,42643$ \\
\hline 148 & $-0,42256$ & 0,09152 & 0,46728 & $-0,61368$ \\
\hline 149 & $-0,60803$ & 2,31724 & 0,88623 & $-0,11041$ \\
\hline 150 & 0,58626 & 0,02023 & $-1,36293$ & $-0,43237$ \\
\hline 151 & $-0,01278$ & $-0,46325$ & 0,08502 & 1,42068 \\
\hline 152 & 1,08441 & $-0,41981$ & $-0,08993$ & $-0,10934$ \\
\hline 153 & 0,65476 & $-0,53322$ & $-0,58346$ & $-0,27436$ \\
\hline 154 & 1,35973 & $-0,49024$ & $-0,85464$ & $-0,04298$ \\
\hline
\end{tabular}




$\begin{array}{lcccc}155 & 0,52767 & -0,72598 & 0,0461 & -0,06988 \\ 156 & 0,87174 & 0,0333 & 0,21191 & 0,04664 \\ 157 & 0,32323 & 2,03019 & 0,12049 & 0,53968 \\ 158 & 0,98602 & -0,19082 & -0,96378 & -0,52539 \\ 159 & 1,5468 & -0,57799 & -0,48523 & -0,13862 \\ 160 & 1,41576 & -0,25463 & -0,59812 & -0,01872 \\ 161 & 1,69254 & -1,21566 & 0,0897 & 0,531 \\ 162 & 0,27625 & 0,69779 & 0,50813 & 1,82092 \\ 163 & 1,02899 & -1,00299 & -1,14937 & -0,5231 \\ 164 & 1,45516 & -0,37617 & -0,33694 & -0,18109 \\ 165 & 2,30269 & -0,47038 & 0,85379 & 0,86123 \\ 166 & 1,62038 & 1,33429 & -0,20591 & 0,45116 \\ 167 & 1,46728 & -0,77619 & -0,81773 & -0,41478 \\ 168 & 0,72432 & -0,29761 & -0,56461 & -0,61464 \\ 169 & 1,41992 & -0,28326 & -0,55308 & -0,14839 \\ 170 & 1,10021 & 1,11746 & -0,36975 & -0,01276 \\ 171 & 1,4074 & -1,01971 & 0,38511 & 1,11616 \\ 172 & 1,54111 & -0,41611 & -0,65645 & -0,06357 \\ 173 & 1,43077 & -0,25679 & -0,01223 & -0,20595 \\ 174 & 0,95824 & -0,62881 & -1,01008 & -0,47311 \\ 175 & 0,85608 & -0,83633 & -2,04002 & -0,50285 \\ 176 & 0,75297 & 0,28817 & -0,71075 & -0,7258 \\ 177 & 1,59604 & -0,9928 & 0,03372 & 0,11382 \\ 178 & 1,11576 & -0,3253 & -0,64435 & -0,50678 \\ 179 & 0,87298 & -0,56783 & -0,9983 & -0,31505 \\ 180 & 1,38288 & -0,5199 & -0,69904 & -0,05527 \\ 181 & 0,94062 & -0,28169 & -0,39604 & -0,34286 \\ 182 & -0,14222 & 1,07202 & 0,03306 & 0,09678 \\ 183 & 1,21989 & 0,00031 & 0,36574 & 1,22434 \\ 184 & 0,69126 & -0,1922 & -0,2451 & -0,22799 \\ 185 & -0,40765 & -0,71978 & -0,01812 & 0,36083 \\ 186 & -0,74499 & 0,44063 & 0,63399 & 0,86957 \\ 187 & -0,05065 & -0,60837 & 1,05731 & 1,29803 \\ 188 & -0,91256 & -0,90818 & -0,38354 & -0,6286 \\ 189 & -0,62513 & -0,71486 & -0,12966 & 0,63844 \\ 190 & -0,84384 & -0,87294 & -0,14728 & -0,07278 \\ 191 & -2,39498 & -0,32258 & -1,52416 & 1,3576 \\ 192 & -1,04138 & -0,44515 & -0,28717 & 0,70909 \\ 193 & 1,05391 & -2,16903 & 1,6955 & 3,74295 \\ 194 & -0,51882 & -0,3984 & 0,48462 & 0,52834 \\ 195 & -1,50693 & -0,35505 & -0,72007 & 1,32747 \\ 196 & -0,28953 & -0,93324 & -1,41798 & -0,07792 \\ 197 & 0,11964 & 0,57191 & 0,75961 & 5,958\end{array}$


ANEXO D4-Valores dos fatores de modernização nos municípios do Estado de Santa Catarina-1980

\begin{tabular}{|c|c|c|c|c|}
\hline MUNICIPIOS & F1 1980 & F2 1980 & F3 1980 & F4 1980 \\
\hline 1 & $-1,21585$ & $-1,16006$ & 0,52248 & 0,71059 \\
\hline 2 & 1,55023 & $-1,21278$ & 0,4321 & 1,81866 \\
\hline 3 & $-0,19381$ & $-1,20777$ & $-1,16325$ & 1,37872 \\
\hline 4 & $-1,22177$ & $-1,21752$ & 0,48538 & $-0,48864$ \\
\hline 5 & $-0,15615$ & $-0,51052$ & 0,04966 & 3,29843 \\
\hline 6 & 0,91139 & $-1,19877$ & $-1,03064$ & 0,67868 \\
\hline 7 & $-0,42784$ & $-1,08086$ & $-0,15021$ & 1,32197 \\
\hline 8 & $-1,22264$ & $-0,72647$ & 0,02724 & $-0,56154$ \\
\hline 9 & $-0,32117$ & $-0,67869$ & $-1,009$ & 1,4098 \\
\hline 10 & 0,76744 & 0,17657 & $-0,38363$ & 8,67545 \\
\hline 11 & 0,35722 & $-1,07658$ & 0,15647 & 1,70297 \\
\hline 12 & 1,25238 & $-0,48683$ & 3,35109 & 1,19353 \\
\hline 13 & 0,32815 & $-1,54103$ & 0,0323 & 1,3645 \\
\hline 14 & $-0,59708$ & $-1,44231$ & $-1,19164$ & 0,56007 \\
\hline 15 & 0,01896 & $-1,00212$ & 0,18832 & 1,73972 \\
\hline 16 & 0,17742 & $-1,62319$ & $-0,30849$ & 0,31953 \\
\hline 17 & 1,3938 & $-0,30489$ & 2,02454 & 2,42879 \\
\hline 18 & $-0,60335$ & 0,08868 & $-0,69866$ & 1,72211 \\
\hline 19 & $-0,77738$ & $-1,11634$ & $-0,98311$ & $-0,11577$ \\
\hline 20 & $-0,38469$ & $-1,66253$ & $-1,51626$ & 0,30994 \\
\hline 21 & $-0,60189$ & $-0,94893$ & $-1,54601$ & 0,21336 \\
\hline 22 & $-0,33727$ & $-1,47774$ & $-1,05587$ & 0,31934 \\
\hline 23 & $-0,20219$ & $-1,45939$ & $-0,97796$ & 1,02226 \\
\hline 24 & $-0,85929$ & $-1,28093$ & $-1,85761$ & $-0,27771$ \\
\hline 25 & $-0,48724$ & $-1,63276$ & $-0,92078$ & 0,27896 \\
\hline 26 & $-0,45122$ & $-0,70852$ & $-0,89371$ & 0,21927 \\
\hline 27 & $-0,01478$ & $-0,63672$ & $-0,85509$ & 2,22247 \\
\hline 28 & $-0,30466$ & $-1,17966$ & $-1,79895$ & 0,19188 \\
\hline 29 & $-0,48994$ & $-0,83025$ & $-0,64904$ & 0,16069 \\
\hline 30 & $-0,50301$ & $-1,34312$ & $-0,98814$ & $-0,53239$ \\
\hline 31 & $-0,43289$ & $-0,81635$ & $-0,97531$ & 1,58551 \\
\hline 32 & 1,09357 & $-1,50452$ & $-1,41531$ & 1,49148 \\
\hline 33 & $-0,8887$ & 0,24741 & $-0,94232$ & 0,50534 \\
\hline 34 & $-0,98324$ & 0,1789 & $-1,24645$ & $-0,02053$ \\
\hline 35 & $-0,62894$ & $-0,9958$ & $-1,173$ & 0,38418 \\
\hline 36 & $-0,92857$ & 0,23337 & $-0,83644$ & 0,58917 \\
\hline 37 & $-0,60245$ & 0,24153 & $-1,00652$ & $-0,0742$ \\
\hline 38 & $-0,65875$ & $-0,80995$ & $-0,81419$ & 1,84309 \\
\hline 39 & $-0,60705$ & $-0,67929$ & $-1,45699$ & 2,7202 \\
\hline 40 & $-0,29432$ & 0,05977 & $-0,75375$ & 3,37843 \\
\hline 41 & $-0,74748$ & 0,33304 & $-0,8015$ & 1,88266 \\
\hline 42 & $-0,7838$ & $-0,29951$ & $-0,81834$ & 2,54655 \\
\hline 43 & $-0,34707$ & 0,09377 & $-0,11914$ & 3,40221 \\
\hline 44 & $-0,43399$ & $-0,74514$ & $-0,88595$ & 1,92863 \\
\hline 45 & $-0,33111$ & $-0,95459$ & $-1,21934$ & 0,57622 \\
\hline 46 & $-1,22363$ & 0,06154 & $-0,73125$ & 0,9511 \\
\hline 47 & $-0,70931$ & $-0,33444$ & $-0,79981$ & 1,48279 \\
\hline 48 & $-0,78249$ & $-0,48076$ & $-1,10293$ & 0,27782 \\
\hline 49 & $-0,57784$ & $-1,02872$ & $-1,31428$ & 1,47343 \\
\hline 50 & $-0,43961$ & $-1,18275$ & $-1,12577$ & 0,85045 \\
\hline
\end{tabular}




\begin{tabular}{|c|c|c|c|c|}
\hline 51 & $-0,50303$ & $-0,0655$ & $-0,97686$ & 0,23755 \\
\hline 52 & $-0,61354$ & $-0,78838$ & $-0,70202$ & 0,05962 \\
\hline 53 & $-0,42533$ & $-1,11809$ & $-1,53229$ & 1,52791 \\
\hline 54 & 0,27938 & $-0,97987$ & $-0,15736$ & $-0,30847$ \\
\hline 55 & $-0,41666$ & $-1,5497$ & $-0,73219$ & 0,06119 \\
\hline 56 & $-1,13625$ & $-0,84678$ & $-0,83681$ & $-3,79845$ \\
\hline 57 & $-0,32945$ & $-1,64959$ & $-0,49188$ & $-0,29562$ \\
\hline 58 & 0,05073 & $-1,15289$ & 0,06802 & 0,51979 \\
\hline 59 & $-0,44248$ & $-1,37588$ & $-1,11627$ & $-0,82566$ \\
\hline 60 & 0,29257 & $-1,576$ & 0,34544 & 0,1526 \\
\hline 61 & $-0,66623$ & $-0,62567$ & $-0,66417$ & 0,92411 \\
\hline 62 & 3,86319 & $-2,32705$ & $-0,51133$ & $-0,21408$ \\
\hline 63 & $-0,12167$ & $-0,55072$ & 1,69771 & 0,84211 \\
\hline 64 & $-0,42777$ & $-1,05401$ & $-1,17268$ & 0,32007 \\
\hline 65 & $-0,95234$ & $-0,94694$ & $-0,22009$ & 0,54095 \\
\hline 66 & $-0,69237$ & $-1,41998$ & $-1,30648$ & $-0,31759$ \\
\hline 67 & $-0,66971$ & $-1,31034$ & $-0,61982$ & $-0,57716$ \\
\hline 68 & $-0,72532$ & $-0,85355$ & $-1,31215$ & $-0,08188$ \\
\hline 69 & $-0,21826$ & $-0,73493$ & $-0,04199$ & 0,48117 \\
\hline 70 & $-0,64541$ & $-0,98996$ & $-1,27477$ & 0,6415 \\
\hline 71 & $-0,92626$ & $-1,06931$ & $-1,2046$ & $-0,19592$ \\
\hline 72 & $-0,62906$ & $-1,39481$ & $-1,467$ & $-0,41804$ \\
\hline 73 & $-0,9796$ & $-1,84811$ & $-0,69371$ & $-0,35326$ \\
\hline 74 & $-0,8698$ & $-0,39191$ & $-1,17047$ & $-1,19865$ \\
\hline 75 & $-0,42794$ & $-0,59846$ & $-0,90477$ & 0,71878 \\
\hline 76 & $-0,84119$ & $-0,38548$ & $-0,85773$ & $-0,89041$ \\
\hline 77 & $-0,55336$ & $-0,81326$ & $-0,60844$ & $-0,08994$ \\
\hline 78 & $-0,32817$ & $-1,49187$ & $-1,09098$ & $-0,98678$ \\
\hline 79 & $-0,4837$ & 0,02309 & $-1,06972$ & $-0,47063$ \\
\hline 80 & $-0,27141$ & 0,2271 & $-0,65679$ & 0,01189 \\
\hline 81 & $-0,39802$ & 0,28718 & $-0,32121$ & 1,37988 \\
\hline 82 & $-0,6737$ & $-0,01911$ & $-1,12068$ & $-0,2151$ \\
\hline 83 & $-0,43874$ & $-1,15971$ & $-1,18817$ & $-0,61364$ \\
\hline 84 & $-0,58308$ & $-0,3499$ & $-1,16072$ & $-0,64211$ \\
\hline 85 & $-0,78745$ & 0,12314 & $-0,59306$ & 0,80735 \\
\hline 86 & 0,26761 & $-0,69651$ & $-0,95826$ & 0,23084 \\
\hline 87 & $-0,56602$ & 0,02142 & $-0,82169$ & 0,49372 \\
\hline 88 & $-0,7104$ & $-0,15733$ & $-1,15875$ & $-1,48975$ \\
\hline 89 & $-1,00609$ & $-0,20604$ & $-1,35076$ & $-1,02875$ \\
\hline 90 & 0,70801 & $-0,50131$ & $-0,60333$ & 0,4347 \\
\hline 91 & $-0,84537$ & 0,05293 & $-0,97522$ & $-0,63037$ \\
\hline 92 & $-1,13149$ & $-0,12484$ & $-0,85774$ & $-0,51778$ \\
\hline 93 & $-0,29666$ & $-0,34696$ & $-0,89803$ & 0,8037 \\
\hline 94 & $-0,16252$ & $-0,42582$ & 0,22627 & 0,7197 \\
\hline 95 & $-0,05417$ & $-0,10742$ & $-0,84589$ & $-0,30626$ \\
\hline 96 & 0,01392 & $-0,44516$ & $-0,1923$ & 0,86175 \\
\hline 97 & $-0,37068$ & $-0,04787$ & $-0,42872$ & 2,04003 \\
\hline 98 & $-0,50457$ & $-0,39158$ & $-0,26776$ & 0,43396 \\
\hline 99 & $-0,12052$ & 0,2234 & $-0,6412$ & 0,91214 \\
\hline 100 & $-0,60136$ & $-0,11165$ & $-0,37054$ & 0,98975 \\
\hline 101 & $-0,60958$ & $-0,50389$ & $-0,8299$ & $-0,05511$ \\
\hline 102 & $-1,00929$ & 0,57945 & $-0,39125$ & 0,83693 \\
\hline
\end{tabular}




\begin{tabular}{|c|c|c|c|c|}
\hline 103 & $-0,59276$ & 0,20426 & $-0,28793$ & 2,51449 \\
\hline 104 & $-0,49354$ & 0,15047 & $-0,13188$ & 1,51964 \\
\hline 105 & $-0,72482$ & 0,34191 & $-0,32468$ & 0,75572 \\
\hline 106 & $-0,93598$ & $-0,61373$ & $-0,82682$ & 0,5137 \\
\hline 107 & $-0,61302$ & 0,08721 & $-0,41315$ & 2,69286 \\
\hline 108 & $-0,68513$ & $-2,0638$ & 1,09073 & $-2,32654$ \\
\hline 109 & $-1,24316$ & $-1,32926$ & 0,49797 & $-0,88187$ \\
\hline 110 & $-0,92598$ & $-1,9489$ & 0,72973 & $-1,75688$ \\
\hline 111 & $-0,91198$ & $-1,60228$ & 1,36094 & $-0,7087$ \\
\hline 112 & $-1,01703$ & $-1,27841$ & $-0,27715$ & $-0,43028$ \\
\hline 113 & $-0,89693$ & $-0,64161$ & $-0,65641$ & $-1,31949$ \\
\hline 114 & $-1,34065$ & $-1,30467$ & 0,51826 & $-1,39112$ \\
\hline 115 & $-0,87594$ & $-0,07186$ & 1,81005 & $-0,21335$ \\
\hline 116 & $-0,83906$ & $-0,77845$ & 3,22355 & $-0,69614$ \\
\hline 117 & $-1,15002$ & $-1,48316$ & 0,83774 & $-1,83413$ \\
\hline 118 & $-0,86803$ & $-1,33646$ & 1,9723 & $-1,3343$ \\
\hline 119 & $-1,08359$ & $-1,67227$ & 0,9334 & $-1,94754$ \\
\hline 120 & $-1,01225$ & $-0,96729$ & $-0,30151$ & $-1,28323$ \\
\hline 121 & $-0,53475$ & $-1,56243$ & 1,46248 & $-1,42543$ \\
\hline 122 & 0,35534 & $-0,00531$ & $-0,72775$ & $-0,64473$ \\
\hline 123 & $-0,94782$ & $-0,54473$ & 0,62381 & $-0,48767$ \\
\hline 124 & 0,84913 & $-0,17458$ & 1,24834 & 0,19204 \\
\hline 125 & $-0,39886$ & $-1,20707$ & 1,05623 & $-0,71224$ \\
\hline 126 & 2,30091 & $-0,02992$ & $-0,3481$ & $-0,73207$ \\
\hline 127 & 0,25208 & $-0,08484$ & 0,142 & $-0,39121$ \\
\hline 128 & 0,94475 & $-0,0966$ & 3,78842 & 0,94638 \\
\hline 129 & 0,61607 & 0,41279 & $-0,39127$ & $-1,27922$ \\
\hline 130 & 0,93534 & $-0,15061$ & $-0,80294$ & $-0,49805$ \\
\hline 131 & $-0,21367$ & 0,22285 & $-0,96863$ & $-1,36243$ \\
\hline 132 & 1,23492 & 0,23525 & $-0,21044$ & $-0,67075$ \\
\hline 133 & $-0,47554$ & $-0,26768$ & $-0,50313$ & $-0,96003$ \\
\hline 134 & 0,44633 & 0,29838 & $-0,56791$ & $-0,75785$ \\
\hline 135 & 1,19267 & $-0,54197$ & $-0,51922$ & $-0,10091$ \\
\hline 136 & 0,12578 & 0,24617 & $-0,61516$ & $-0,23939$ \\
\hline 137 & 0,27008 & 0,07782 & $-0,888$ & $-0,52566$ \\
\hline 138 & 0,48739 & 0,10172 & $-0,2742$ & $-0,42033$ \\
\hline 139 & 0,65346 & 0,20476 & $-0,90916$ & $-0,15572$ \\
\hline 140 & 1,126 & 0,84435 & 0,58728 & 2,404 \\
\hline 141 & $-0,3966$ & 0,41712 & $-0,98159$ & $-1,12626$ \\
\hline 142 & $-0,8372$ & $-0,77573$ & 0,68394 & $-1,05264$ \\
\hline 143 & 1,58325 & 0,21727 & 0,04252 & $-0,88774$ \\
\hline 144 & 0,01654 & $-0,37472$ & 0,03318 & $-0,40393$ \\
\hline 145 & $-0,00063$ & $-0,18531$ & $-0,83906$ & $-1,03422$ \\
\hline 146 & 0,42729 & 0,85507 & $-0,47489$ & $-1,37739$ \\
\hline 147 & $-0,00475$ & 0,01167 & $-0,08242$ & $-0,07317$ \\
\hline 148 & 1,20602 & $-0,90159$ & $-0,94687$ & 0,50677 \\
\hline 149 & 1,85476 & $-0,29848$ & 0,28293 & 0,75078 \\
\hline 150 & 0,648 & 0,32011 & $-0,55419$ & $-1,5996$ \\
\hline 151 & $-0,64488$ & 0,8048 & 2,05691 & 0,66376 \\
\hline 152 & $-0,9921$ & 1,72133 & $-0,32039$ & $-0,15625$ \\
\hline 153 & $-0,61701$ & 1,21221 & $-0,34873$ & $-1,12022$ \\
\hline 154 & $-0,43684$ & 1,67307 & $-0,20988$ & $-0,38264$ \\
\hline
\end{tabular}




$\begin{array}{lcccc}155 & -0,8345 & 0,70195 & 0,17624 & -0,01645 \\ 156 & -0,33217 & 1,15201 & -0,45039 & 0,30115 \\ 157 & 1,09945 & 0,235 & 0,28015 & 0,06002 \\ 158 & -0,35538 & 1,36637 & -0,41172 & -0,3386 \\ 159 & -0,5937 & 1,59931 & -0,29363 & 0,09109 \\ 160 & -0,38673 & 1,45826 & -0,26391 & -0,23595 \\ 161 & -1,15872 & 1,82204 & 0,8255 & 0,00721 \\ 162 & 0,615 & 1,00613 & 2,13353 & 1,37122 \\ 163 & -0,74634 & 1,20056 & -0,40387 & -0,47327 \\ 164 & -0,45754 & 1,6886 & -0,25225 & -0,16888 \\ 165 & -0,63864 & 1,34405 & 0,3139 & 0,13758 \\ 166 & 0,42884 & 1,43278 & 0,26059 & -0,67084 \\ 167 & -0,65516 & 1,65023 & -0,41796 & -0,25758 \\ 168 & -0,65875 & 1,86711 & 0,18614 & 0,09099 \\ 169 & -0,37694 & 1,65628 & -0,06275 & -0,54237 \\ 170 & 0,55812 & 0,80382 & -0,35469 & 0,55834 \\ 171 & -0,51902 & 0,47485 & 0,40061 & 0,26686 \\ 172 & -0,17566 & 1,70244 & -0,1776 & -0,14244 \\ 173 & -0,21828 & 1,84655 & -0,27146 & 0,68097 \\ 174 & -0,48096 & 0,93348 & -0,63362 & -0,26471 \\ 175 & -0,69929 & 1,18029 & -0,66747 & -1,49673 \\ 176 & 0,13336 & 2,0138 & -0,1948 & -0,41261 \\ 177 & -0,70402 & 1,07155 & 0,27486 & 0,83102 \\ 178 & -0,1028 & 1,55998 & -0,14471 & -0,69332 \\ 179 & -0,62104 & 1,02916 & -0,34529 & -1,18906 \\ 180 & -0,66 & 1,49042 & -0,45764 & -0,80644 \\ 181 & -0,37239 & 1,80565 & -0,05721 & -0,06054 \\ 182 & 0,25764 & 0,34119 & 1,22646 & 1,58625 \\ 183 & 1,34154 & 0,11414 & 1,23017 & 0,78647 \\ 184 & 0,65776 & 0,15571 & 0,03815 & -0,23766 \\ 185 & -0,64866 & -0,85762 & -0,15994 & -0,8664 \\ 186 & -0,76451 & 0,00352 & 0,96165 & 0,88283 \\ 187 & -1,00954 & 0,15472 & 1,06694 & 1,36556 \\ 188 & -0,92263 & -0,94142 & -0,83079 & -0,32653 \\ 189 & -0,99732 & -0,2633 & 0,73464 & 0,19369 \\ 190 & -0,97985 & -0,96766 & -0,59162 & -0,09162 \\ 191 & -1,04669 & -1,84433 & 0,05707 & -1,92892 \\ 192 & -1,22378 & -0,78815 & 0,09898 & -0,32269 \\ 193 & -0,66882 & 0,1203 & 1,08035 & 0,78459 \\ 194 & -0,6427 & -0,63487 & -0,36337 & 0,4352 \\ 195 & -1,13448 & -1,3003 & 0,56678 & -0,41034 \\ 196 & -0,92545 & -1,05939 & -1,1171 & -0,12217 \\ 197 & -0,40899 & -0,94185 & 2,5396 & 1,16018\end{array}$


ANEXO D5-Valores do fatores de modernização nos municípios do Estado de Santa Catarina-1985

\begin{tabular}{|c|c|c|c|c|}
\hline MUNICÍPIOS & F1 1985 & F2 1985 & F3 1985 & F4 1985 \\
\hline 1 & $-1,56825$ & $-0,30931$ & $-0,0376$ & 0,17834 \\
\hline 2 & $-0,37939$ & $-0,53746$ & $-0,34552$ & 0,91151 \\
\hline 3 & $-0,09206$ & $-0,72725$ & $-0,92217$ & 0,65634 \\
\hline 4 & $-1,22198$ & $-0,00899$ & $-1,09606$ & $-0,62459$ \\
\hline 5 & $-0,19119$ & $-0,24108$ & $-0,30524$ & 2,02296 \\
\hline 6 & 0,14117 & $-0,3063$ & $-0,89129$ & 0,35682 \\
\hline 7 & $-0,34695$ & $-0,52792$ & $-0,74379$ & 0,63506 \\
\hline 8 & $-0,88537$ & $-0,79468$ & $-0,51548$ & $-0,95355$ \\
\hline 9 & 0,13453 & $-0,4246$ & $-1,0466$ & 1,48688 \\
\hline 10 & $-0,39262$ & $-0,62838$ & $-1,21545$ & 0,20977 \\
\hline 11 & $-0,47514$ & $-0,54082$ & $-0,43497$ & 0,5075 \\
\hline 12 & $-0,6962$ & $-0,64969$ & 0,18224 & 0,71097 \\
\hline 13 & $-1,60649$ & $-0,14827$ & $-0,03958$ & 0,7521 \\
\hline 14 & $-0,20304$ & $-0,44508$ & $-0,02545$ & 0,16868 \\
\hline 15 & $-1,62911$ & $-0,63071$ & 2,19425 & 0,70088 \\
\hline 16 & $-0,9907$ & $-0,1995$ & 1,02063 & $-0,21202$ \\
\hline 17 & $-0,99846$ & $-0,55585$ & 0,91877 & 1,22239 \\
\hline 18 & $-0,34411$ & $-0,37038$ & $-1,04344$ & 1,93244 \\
\hline 19 & $-0,18308$ & $-0,60871$ & $-1,13902$ & $-0,15096$ \\
\hline 20 & $-0,17092$ & $-0,71519$ & $-1,53487$ & 0,07042 \\
\hline 21 & 0,44904 & $-0,71913$ & $-0,75549$ & 0,48469 \\
\hline 22 & $-0,42627$ & $-0,65769$ & $-1,25426$ & $-0,01666$ \\
\hline 23 & $-0,39247$ & $-0,45443$ & $-0,78578$ & 0,75949 \\
\hline 24 & 0,27765 & $-0,71114$ & $-1,36969$ & 0,54816 \\
\hline 25 & $-0,29624$ & $-0,69823$ & $-1,20576$ & 0,0829 \\
\hline 26 & 0,10876 & $-0,80959$ & $-0,84941$ & 0,31124 \\
\hline 27 & 0,41151 & $-0,35389$ & $-0,64408$ & 1,87741 \\
\hline 28 & 0,27258 & $-0,82064$ & $-1,34525$ & 0,09114 \\
\hline 29 & 0,19983 & $-0,76765$ & $-0,52217$ & $-0,4109$ \\
\hline 30 & $-0,25799$ & $-0,85573$ & $-1,29424$ & $-0,12609$ \\
\hline 31 & 0,28642 & $-0,82005$ & $-1,24952$ & 0,82875 \\
\hline 32 & 0,20486 & $-0,44927$ & $-1,2994$ & 1,01944 \\
\hline 33 & 0,33944 & $-0,64067$ & $-0,47558$ & 1,1599 \\
\hline 34 & 0,32421 & $-0,79358$ & $-1,22441$ & 0,1771 \\
\hline 35 & 0,14863 & $-0,6269$ & $-0,94159$ & 0,45379 \\
\hline 36 & 0,4715 & $-0,50053$ & $-0,93827$ & 0,74177 \\
\hline 37 & 0,46728 & $-0,70829$ & $-0,77256$ & 0,72253 \\
\hline 38 & 0,35487 & $-0,41594$ & $-0,9106$ & 1,81631 \\
\hline 39 & 0,47541 & $-0,31596$ & $-0,9158$ & 2,4734 \\
\hline 40 & 0,44367 & $-0,19555$ & $-0,75656$ & 2,83142 \\
\hline 41 & 0,75065 & $-0,28723$ & $-0,53785$ & 1,81568 \\
\hline 42 & 0,48572 & $-0,33721$ & $-0,84754$ & 2,18651 \\
\hline 43 & 0,54602 & $-0,27318$ & $-0,3781$ & 2,96425 \\
\hline 44 & 0,50344 & $-0,05587$ & $-0,96684$ & 1,71635 \\
\hline 45 & 0,33732 & $-0,54843$ & $-1,09474$ & 0,69778 \\
\hline 46 & $-0,10955$ & $-0,21755$ & $-0,87838$ & 2,57385 \\
\hline 47 & 0,33808 & $-0,49192$ & $-0,64212$ & 1,26377 \\
\hline 48 & 0,10352 & $-0,6905$ & $-0,70979$ & 0,2527 \\
\hline 49 & 0,26095 & $-0,49826$ & $-1,15599$ & 1,67123 \\
\hline 50 & 0,0536 & $-0,50528$ & $-0,98499$ & 0,70434 \\
\hline
\end{tabular}




\begin{tabular}{|c|c|c|c|c|}
\hline 51 & 0,62206 & $-0,46539$ & $-0,60327$ & 0,20862 \\
\hline 52 & $-0,15802$ & $-0,43124$ & $-0,50513$ & 0,09843 \\
\hline 53 & 0,17102 & $-0,45338$ & $-1,23033$ & 1,41828 \\
\hline 54 & $-0,5618$ & $-0,53523$ & $-0,7641$ & $-0,37902$ \\
\hline 55 & $-1,05389$ & $-0,62627$ & $-0,52395$ & $-0,10747$ \\
\hline 56 & $-0,63894$ & $-0,62121$ & $-1,02865$ & $-1,56745$ \\
\hline 57 & $-0,98556$ & $-0,59925$ & 1,04869 & 0,0085 \\
\hline 58 & $-0,99596$ & $-0,44948$ & $-0,14242$ & $-0,17646$ \\
\hline 59 & $-1,3146$ & $-0,46212$ & $-0,98323$ & $-1,4382$ \\
\hline 60 & $-1,4565$ & $-0,37753$ & $-0,08524$ & $-0,45467$ \\
\hline 61 & 0,11528 & $-0,72018$ & $-0,55997$ & 0,63099 \\
\hline 62 & $-0,73715$ & $-0,84188$ & 0,29387 & $-1,02718$ \\
\hline 63 & $-1,02005$ & $-0,54405$ & 0,62074 & 0,05172 \\
\hline 64 & 0,33522 & $-0,5962$ & $-1,20446$ & 0,06506 \\
\hline 65 & $-0,23266$ & $-0,67039$ & $-1,0912$ & 0,5991 \\
\hline 66 & $-0,12366$ & $-0,82259$ & $-1,43311$ & $-0,23905$ \\
\hline 67 & $-0,23051$ & $-0,72085$ & $-1,30727$ & $-0,60858$ \\
\hline 68 & 0,26961 & $-0,64691$ & $-1,11927$ & $-0,0571$ \\
\hline 69 & $-0,05239$ & $-0,73765$ & 0,44355 & 0,60412 \\
\hline 70 & 0,08975 & $-0,5208$ & $-1,29359$ & 0,48162 \\
\hline 71 & 0,02684 & $-0,7984$ & $-1,20865$ & 0,42823 \\
\hline 72 & 0,26599 & $-0,63529$ & $-1,10446$ & 0,38826 \\
\hline 73 & $-1,28514$ & $-0,48869$ & $-1,36206$ & 0,14673 \\
\hline 74 & 0,08558 & $-0,65211$ & $-1,22627$ & $-0,47086$ \\
\hline 75 & 0,47221 & $-0,65538$ & $-1,22075$ & 0,73016 \\
\hline 76 & 0,21944 & $-0,82922$ & $-0,50289$ & $-0,96463$ \\
\hline 77 & $-0,27187$ & $-0,67505$ & 0,46561 & $-0,09954$ \\
\hline 78 & $-0,44478$ & $-0,75235$ & $-0,48175$ & $-0,47785$ \\
\hline 79 & 0,88959 & $-0,65535$ & $-0,30741$ & $-0,50616$ \\
\hline 80 & 0,88312 & $-0,17586$ & $-0,32016$ & 0,05072 \\
\hline 81 & 0,18997 & $-0,23412$ & $-0,02005$ & 1,58383 \\
\hline 82 & 0,33443 & $-0,37316$ & $-0,53391$ & 0,5325 \\
\hline 83 & $-0,1283$ & $-0,66448$ & $-0,85966$ & $-0,47584$ \\
\hline 84 & 0,43901 & $-0,55561$ & $-0,42779$ & $-0,47052$ \\
\hline 85 & 0,45554 & $-0,23588$ & $-0,35828$ & 1,24751 \\
\hline 86 & 0,39702 & $-0,12459$ & $-0,40379$ & 0,54517 \\
\hline 87 & 0,5055 & $-0,57544$ & $-0,18926$ & 0,52867 \\
\hline 88 & 0,55998 & $-0,68035$ & $-0,93221$ & $-0,41942$ \\
\hline 89 & 0,46625 & $-0,72472$ & $-1,01911$ & $-0,55575$ \\
\hline 90 & 0,23266 & $-0,38126$ & 0,80759 & 0,15608 \\
\hline 91 & 0,66586 & $-0,65364$ & $-0,98594$ & $-0,63286$ \\
\hline 92 & 0,19651 & $-0,51079$ & $-1,12955$ & 0,07242 \\
\hline 93 & 0,41373 & $-0,60259$ & $-0,18002$ & 0,96921 \\
\hline 94 & $-0,07848$ & $-0,75781$ & 0,67584 & 0,43161 \\
\hline 95 & 0,0806 & $-0,37009$ & $-0,49932$ & $-0,10781$ \\
\hline 96 & $-0,13165$ & 0,90782 & $-1,18073$ & 3,96033 \\
\hline 97 & $-0,10497$ & 0,24824 & $-0,01083$ & 3,02593 \\
\hline 98 & $-0,09572$ & $-0,54996$ & $-0,17526$ & 0,28302 \\
\hline 99 & 0,00451 & 0,54265 & 0,88386 & 1,74547 \\
\hline 100 & 0,23103 & $-0,56572$ & $-0,1764$ & 0,92998 \\
\hline 101 & 0,18806 & $-0,57351$ & $-0,15788$ & 0,45488 \\
\hline 102 & 0,24387 & $-0,31469$ & $-0,11755$ & 1,0717 \\
\hline
\end{tabular}




\begin{tabular}{|c|c|c|c|c|}
\hline 103 & 0.40505 & $-0,09171$ & 0,75242 & 3,01837 \\
\hline 104 & 0,20076 & $-0,36167$ & $-0,09068$ & 1,59841 \\
\hline 105 & 0,4607 & $-0,54073$ & 0,31109 & 0,50859 \\
\hline 106 & 0,03423 & $-0,52248$ & $-0,35916$ & 0,60242 \\
\hline 107 & 0,43253 & $-0,16756$ & 1,25171 & 2,92072 \\
\hline 108 & $-2,3062$ & $-0,27685$ & $-0,91124$ & $-1,28631$ \\
\hline 109 & $-1,71951$ & $-0,5178$ & $-0,81085$ & $-0,33064$ \\
\hline 110 & $-1,94308$ & $-0,3274$ & $-1,26595$ & $-0,75512$ \\
\hline 111 & $-3,0327$ & 0,00692 & $-1,23506$ & $-1,37639$ \\
\hline 112 & $-2,72899$ & 0,23069 & $-1,04354$ & $-0,27354$ \\
\hline 113 & $-2,23518$ & $-0,34088$ & $-0,34655$ & $-0,41063$ \\
\hline 114 & $-1,24501$ & $-0,6254$ & $-1,12932$ & $-0,05585$ \\
\hline 115 & $-0,31273$ & $-0,67387$ & $-1,00192$ & $-0,89003$ \\
\hline 116 & $-1,83333$ & $-0,45735$ & $-1,10955$ & $-1,46312$ \\
\hline 117 & $-1,26341$ & $-0,4283$ & 0,50211 & $-0,19849$ \\
\hline 118 & $-2,92754$ & 0,09287 & $-0,48127$ & $-0,10941$ \\
\hline 119 & $-2,67233$ & 0,13687 & $-0,55615$ & $-0,94159$ \\
\hline 120 & $-2,21943$ & $-0,06256$ & $-0,7135$ & $-0,76594$ \\
\hline 121 & $-3,47248$ & 0,17043 & $-0,8749$ & $-1,20541$ \\
\hline 122 & $-0,82951$ & $-0,61435$ & $-0,74513$ & $-0,7641$ \\
\hline 123 & $-2,2564$ & $-0,11524$ & $-0,70779$ & $-1,22365$ \\
\hline 124 & 0,2705 & $-0,40624$ & $-0,56591$ & $-0,23313$ \\
\hline 125 & $-1,23755$ & $-0,51215$ & $-0,54662$ & $-0,19869$ \\
\hline 126 & $-0,84937$ & 0,38469 & 1,07091 & $-0,16815$ \\
\hline 127 & $-1,98573$ & 0,01958 & $-0,55417$ & $-0,65706$ \\
\hline 128 & 0,66463 & 0,27718 & 0,09003 & $-0,67193$ \\
\hline 129 & 0,04506 & $-0,55641$ & $-0,32496$ & $-0,50499$ \\
\hline 130 & $-2,0911$ & $-0,40639$ & 3,11645 & 0,46135 \\
\hline 131 & 0,55356 & $-0,33289$ & $-0,35678$ & $-0,88998$ \\
\hline 132 & 0,64079 & $-0,39001$ & $-0,28162$ & $-0,76768$ \\
\hline 133 & 0,86597 & $-0,13998$ & $-0,04276$ & $-2,04002$ \\
\hline 134 & 0,65341 & $-0,31601$ & 0,01033 & $-0,53137$ \\
\hline 135 & 0,00817 & $-0,45565$ & $-0,58605$ & $-1,21007$ \\
\hline 136 & 0,61944 & $-0,54991$ & $-0,04946$ & $-0,85313$ \\
\hline 137 & 0,30578 & 0,00166 & $-0,10422$ & $-0,31361$ \\
\hline 138 & 0,28743 & $-0,38003$ & $-0,54219$ & $-0,28739$ \\
\hline 139 & 0,67175 & $-0,20422$ & $-0,63434$ & 0,0012 \\
\hline 140 & 0,70505 & $-0,34794$ & $-0,16284$ & $-0,38156$ \\
\hline 141 & 0,91759 & $-0,4242$ & $-0,15584$ & $-0,56207$ \\
\hline 142 & $-0,23481$ & 0,03054 & $-0,55743$ & 1,76209 \\
\hline 143 & 1,02209 & $-0,58742$ & $-0,34898$ & $-1,12424$ \\
\hline 144 & $-1,83761$ & $-0,30818$ & $-0,6726$ & $-0,66722$ \\
\hline 145 & 0,3922 & 0,11016 & $-0,18487$ & $-0,44311$ \\
\hline 146 & $-0,48005$ & 0,36411 & $-0,16196$ & 0,00263 \\
\hline 147 & 0,37486 & $-0,13116$ & $-0,55359$ & $-0,86346$ \\
\hline 148 & 0,99712 & $-0,17862$ & 0,31624 & $-1,47789$ \\
\hline 149 & 0,2995 & $-0,48392$ & $-0,1557$ & $-0,33923$ \\
\hline 150 & 0,1162 & $-0,13591$ & $-0,70476$ & 0,05716 \\
\hline 151 & $-0,04725$ & 0,15964 & $-0,12803$ & 0,06506 \\
\hline 152 & 0,63001 & $-0,0309$ & $-0,22355$ & $-1,46678$ \\
\hline 153 & $-0,61422$ & $-0,59004$ & 1,07024 & 0,17187 \\
\hline 154 & 1,35447 & $-0,48756$ & 0,25444 & $-0,47123$ \\
\hline
\end{tabular}




$\begin{array}{lcccc}155 & 1,2432 & -0,70267 & 0,2958 & -1,35974 \\ 156 & 1,44869 & -0,58555 & 0,06904 & -0,5041 \\ 157 & 0,61404 & -0,90618 & 0,54162 & -0,64293 \\ 158 & 1,14601 & -0,54743 & 0,3394 & -0,14224 \\ 159 & 0,22034 & 0,0939 & 0,53562 & -0,2962 \\ 160 & 1,0912 & -0,48639 & 0,01506 & -0,66713 \\ 161 & 1,31495 & -0,46761 & 0,30685 & -0,43649 \\ 162 & 1,28773 & -0,51124 & 0,37242 & -0,70504 \\ 163 & 0,98612 & -0,88024 & 0,10632 & -0,56158 \\ 164 & -1,22425 & -0,11253 & 6,38862 & 0,0987 \\ 165 & 0,80111 & -0,72972 & 0,59433 & -0,55928 \\ 166 & 1,19 & -0,53906 & 0,40044 & -0,60174 \\ 167 & 1,19228 & -0,42166 & 0,21446 & -0,31906 \\ 168 & 0,14406 & 3,18319 & -0,27429 & -0,05512 \\ 169 & 1,22939 & -0,53741 & 0,13815 & -0,34401 \\ 170 & 1,24362 & -0,61574 & 0,50833 & -0,73009 \\ 171 & 1,16756 & -0,47066 & 0,03172 & -0,9743 \\ 172 & 1,14488 & -0,23159 & 0,87321 & -0,0435 \\ 173 & 0,3865 & -0,82602 & 0,93983 & -0,24663 \\ 174 & 1,21164 & -0,21297 & 0,28883 & -0,19839 \\ 175 & 1,27806 & -0,19493 & 0,59737 & -0,09698 \\ 176 & 0,88882 & -0,68159 & -0,17249 & -0,67877 \\ 177 & 1,05133 & -0,53887 & 0,23947 & -1,50819 \\ 178 & 1,57753 & -0,2054 & 0,48469 & -0,5789 \\ 179 & 0,35588 & -0,75687 & 0,49064 & 0,22411 \\ 180 & 1,22101 & -0,34022 & 0,13781 & -0,94061 \\ 181 & 0,82052 & -0,77982 & -0,1787 & -1,03145 \\ 182 & 1,10606 & -0,56279 & 0,05379 & -0,95513 \\ 183 & 1,32098 & -0,2658 & 0,5595 & -0,98692 \\ 184 & -0,03374 & -0,58453 & 1,18148 & 0,50341 \\ 185 & -0,11864 & -0,53217 & 1,21179 & 0,19404 \\ 186 & 0,27739 & 1,05992 & 0,64816 & -0,52185 \\ 187 & 0,05271 & -0,84172 & -0,84636 & -0,25962 \\ 188 & -0,37751 & -0,68508 & -0,07828 & 0,70906 \\ 189 & -0,29166 & -0,72913 & 0,19977 & 1,00459 \\ 190 & -0,49747 & -0,8668 & -0,76708 & -0,56327 \\ 191 & -0,6878 & -0,67386 & -0,27519 & 0,1348 \\ 192 & -0,69448 & -0,78133 & -0,21585 & -0,02552 \\ 193 & -2,56707 & -0,24292 & -1,1997 & -1,33038 \\ 194 & -1,12248 & -0,72924 & -0,0348 & -0,21798 \\ 195 & -0,48309 & -0,70949 & 0,45598 & 0,45358 \\ 196 & -0,20442 & -0,71581 & -0,8502 & -0,00802 \\ 197 & -1,69494 & -0,28269 & -0,53393 & -0,27701 \\ 198 & -0,15635 & -0,75831 & -1,02734 & -0,27735 \\ 199 & -1,96928 & -0,10739 & 2,15826 & 1,1671\end{array}$




\section{BIBLIOGRAFIA}

ALVES, E. Reflexões sobre política agrícola. R. Econ. Sociol. Rural, Brasília, v. 31, n.2, p.91-102, abr./jun. 1993.

ALVES, E.R.; PASTORE, A.C. A política agrícola no Brasil e hipótese de inova ção induzida. In: Coletânea de trabalhos sobre a EMBRAPA. Brasília, 1980. p.9-19.

ANDRADE, M. P. de. Estrutura fundiária, modernização e distribuição de ren da na agricultura matogrossense. Piracicaba, 1989. 201 p. Dissertação de mestrado-ESALQ/USP.

ARAÚJO, P. F. C. de . Agricultura no processo de desenvolvimento econômico. In: ARAÚJO, P.F.C. de; SCHUH, G.E. Desenvolvimento da agricultura: natureza do processo e modelos dualistas. São Paulo: Pioneira, 1975. Livro 1. 
et al. Crescimento e desenvolvimento da agricultura paulista. In:ARAÚJO, P.F.C. de; SCHUH, G.E. Desenvolvimento da agricultura brasileira. Estudos de casos. São Paulo: Pioneira, 1983. p.279-303.

ARAÚJO, P.F.C. de; MEYER, R.L. Política de crédito agrícola no Brasil: objetivos e resultados. In: ARAÚJO, P.F.C. de; SCHUH, G.E. Desenvolvimento da agricultura. Estudos de casos. São Paulo: Pioneira, 1983. p.305-28.

BARROS, J.R.M.; PASTORE, A.C.; RIZZIERI, J. A. B. A evolução recente da agricultura brasileira. In: Estudos sobre a modernização da agricultura brasileira. Série IPE, monografias, 1977. p.107-38.

BECKER, G.S. Investiment in human capital: a theoretical analysis. The Journal of Political Economy, 70(5):9-49, 1962.

BRASIL. Anuário Estatístico do Brasil. Rio de Janeiro, 1917. v.II . Recenseamento do Brasil. Superfície territorial, área e valor dos imóveis recenseados. Categoria e nacionalidade dos proprietários. Sistema de exploração rural. Recenseamento do gado. Rio de Janeiro, 1923. v. III. 512p.

. Recenseamento do Brasil. Agricultura. Superficie do Brasil. Área recenseada e área cultivada. Produção agrícola. Produção florestal. Produção animal. Rio de Janeiro, 1924. v. III. 526 p. 
. Recenseamento do Brasil. Agricultura (instrumentos e máquinas agrícolas dos estabelecimentos rurais - beneficiamento da produção). Rio de Janeiro, 1927. v. VIII. 367 p.

Recenseamento do Brasil. População. Rio de Janeiro, 1930. v.IV, Tomo II. $851 \mathrm{p}$.

BROWN, L.R. Revolução agrícola na Ásia. In: ARAÚJO, P.F.C. de; SCHUH, G. E. Desenvolvimento da agricultura brasileira. Estudos de casos. São Paulo: Pioneira, 1983. p. 129-137.

CÂMARA, L. A concentração da propriedade agrária no Brasil. Boletim Geográ fico do IBGE, v.II, 77, p.516-28, 1949.

CARVALHO, D.; BACHA, C.J.C. Mercado de trabalho na agricultura brasileira: década de 80. R. Econ.Sociol. Rural, Brasília, v.32, n.3, p.255-88, jul./set.1994.

CAZELlA, A. Ações fundiárias em Santa Catarina. Agropecuária Catarinense, Florianópolis, v.8, n.4, p.40-42, dez. 1995.

CEAG/SC-CENTRO DE ASSISTÊNCIA GERENCIAL DE SANTA CATARINA Evolução histórico-econômica de Santa Catarina; estudo das alterações estruturais (século XVII-1960).Florianópolis: CEAG/SC, 1980. 217p. 
CEPAL- COMISION ECONOMICA PARA AMERICA LATINA Y EL CARIBE Anuario Estadistico de America Latina y el Caribe, Edicion 1994. Nacio nes Unidas: Chile, 1995. 781p.

CHATFIELD, C. ; COLLINS, A.J. Introduction to multivariate analysis. Lon don: Chapman \& Hall, 1980. 246p.

CLINE, W.R. Economics consequences of land reform in Brazil. Amsterdam: North Holland, 1970.

. Distribution and development: a survey of literature. Journal of Development Economics, 1(4): 359-400, 1975.

CORRÊA, A.M.C.J. Distribuição de rendimentos e pobreza na agricultura bra sileira: 1981-1990. Piracicaba, 1995. 356p. Tese de doutorado-ESALQ/USP.

CUNHA, A.S. Rural poverty and agricultural modernization in Brazil. Nash ville, Tennessee, 1978. 245p. Tese de PhD, Vanderbilt University.

DE JANVRY, A. Social structure and biased technical change in Argentine agriculture. In: BISWANGER, H.P.; RUTTAN, V.W. Induced inovations. The Johns Hopkins University Press, 1978. p.297-326.

DELGADO, G.C. Capital financeiro e agricultura no Brasil: 1965-85. Campipinas: UNICAMP, 1985. 240p. 
. Capital e política agrária no Brasil: 1930-1980. In: História econômica do Brasil contemporâneo. São Paulo: Hucitec, 1997. p. 209-226.

DEL GROSSI, M.S. Distribuição de renda na agropecuária paranaense. Pira cicaba, 1989. 129p. Dissertação de mestrado - ESALQ/USP.

ESPÍRITO SANTO, E.N.do. Modernização da agricultura catarinense no perío do 1975-1985. Piracicaba: ESALQ/USP, 1995. 27p. (não publicado).

EVENSON, R. Revolução verde na experiência recente de desenvolvimento. In: ARAÚJO, P.F.C. de; SCHUH, G.E. Desenvolvimento da agricultura brasileira. Estudos de casos. São Paulo: Pioneira, 1983 . p. 139-151.

FAO. ORGANIZAÇÃO DAS NAÇÕES UNIDAS PARA A AGRICULTURA E ALIMENTAÇÃO. Diretrizes de política agrária e desenvolvimento sustentável. Brasília: 1994. 24p.

FIELDS, G.S. Poverty, inequality and development. New York: Cambridge, U. p., 1980.

FIESC. FEDERAÇÃO DAS INDÚSTRIAS DO ESTADO DE SANTA CATARINA. Santa Catarina em dados-1994. Florianópolis: FIESC, Setor Econômico Estatístico, 1995. v.6, p.1-95.

FIGUEIREDO, N.M.S. Modernização, distribuição da renda e pobreza na agricultura brasileira, 1975, 1980 e 1985. Piracicaba, 1996. 248p. Tese de doutorado-ESALQ/USP. 
FURTADO, C. Análise do modelo brasileiro. São Paulo: Civilização Brasileira, 1972. 122p.

FURTADO, M.B. Síntese da economia brasileira. Rio de Janeiro: LTC LTDA, 1988. $254 \mathrm{p}$.

GRILICHES, Z. Hybrid corn: an exploration in the economics of technological change. Econometrica, 25(4):501-22, Oct. 1957.

GUIMARÃES, A.P. Quatro séculos de latifúndio. Rio de Janeiro: Paz e Terra, 1977. 255p.

HAYAMI, Y.; RUTTAN, V. Agricultural development, an international perspective. Baltimore: Johns Hopkins Press, 1971. 367p.

Desenvolvimento agrícola: teoria e experiências internacionais. Brasília: EMBRAPA, 1988. 583 p.

HARMANN, H.H. Modern factor analysis. Chicago: The University of Chicago Press, 1976. 487p.

HESS, E. et al (coord.). Impacto da expansão das culturas voltadas às alterna tivas energéticas e à exportação sobre a agricultura de alimentos. Curitiba: IPARDES, Fundação Edison Vieira, 1983. 2v.

HOFFMANN, R. Contribuição à análise da distribuição da posse da terra no Brasil. Piracicaba, 1967. 65p. Dissertação de mestrado-ESALQ/USP. 
. Contribuição à análise da distribuição da renda e da posse

da terra no Brasil. Piracicaba, 1971. 161p. Tese de Livre-docênciaESALQ/USP.

. Estimação da desigualdade dentro de estratos no cálculo do ín dice de Gini e da redundância. Pesquisa e planejamento econômico, Rio de Janeiro, 9(3) 719-38, dez. 1979.

. Estatística para economistas. São Paulo: Pioneira, 1980. 379p.

. Evolução da desigualdade da distribuição da posse da terra no

Brasil no período 1960-80. Reforma Agrária, Campinas, v.12(6), p.1734, nov./dez. 1982.

A distribuição da renda e pobreza na agricultura brasileira. São Paulo: IPEA, ESALQ/USP, 1987. 151p.

. O índice de desigualdade de Theil-Atkinson. Anais do XI en contro brasileiro de econometria. Fortaleza, 1989. p. 193-210.

. A dinâmica da modernização da agricultura em 157 microrregiões homogêneas do Brasil. R. Econ.Sociol.Rural, Brasília, v.30, n.4, p.27190, out./dez. 1992.

Componentes principais e análise fatorial. Série didática, $n .90$ DESR/ESALQ, 1994. 37p. 
et al. Administração da empresa agrícola. São Paulo: Pioneira 1984. 325p.

et al. Inovações tecnológicas e transformações recentes na agri cultura brasileira. Relatório de pesquisa. FINEP/USP, 1985. v.1.

HOFFMANN, R.; KAGEYAMA, A. Modernização da agricultura e distribuição de renda no Brasil. Pesquisa e Planejamento Econômico, Rio de Janeiro, 15(1), 171-208, Abr. 1985.

. Distribuição de renda no Brasil entre famílias e entre pessoas em 1970 e 1980. Estudos Econômicos, São Paulo, 16(1): 25-51, jan./abr. 1986.

HOFFMANN, R.; KASSOUF, A. L. Modernização e desigualdade na agricultura. Revista Brasileira de Economia, Rio de janeiro, 43(2): 273-303, abr./jun. 1989.

IBGE. FUNDAÇÃO INSTITUTO BRASILEIRO DE GEOGRAFIA E ESTATÍSTICA. Censo Demográfico: Estado de Santa Catarina-1950. Rio de Janeiro: IBGE, 1951. V. XXVII, tomo 2. 284 p.

. Censos Econômicos de 1950. Série regional. Rio de Janeiro: IBGE, 1956.

. Censos Econômicos de 1975. Santa Catarina. Rio de Janeiro: IBGE, 1979

Censos Econômicos de 1980. Santa Catarina. Rio de Janeiro: IBGE, 1983 
.Censos Econômicos de 1985. Santa Catarina. Rio de Janeiro: IBGE, 1990

. Censo Demográfico 1970. Rio de Janeiro: IBGE, 1973. v.1, tomo XX, n. IX, Santa Catarina.

. Censo Demográfico 1980. Rio de Janeiro: IBGE, 1982. v. 1, tomo 4, n.

21, Santa Catarina.

.Sinopse preliminar do Censo Demográfico, 1991. Rio de Janeiro: IBGE, 1991. v.6, p.1-91, Santa Catarina.

.Censo Demográfico 1991. Rio de Janeiro: IBGE, 1994. n. 23. Santa Catarina.

INSTITUTO CEPA / SC. INSTITUTO DE PLANEJAMENTO E ECONOMIA AGRÍCOLA DE SANTA CATARINA. Estudos básicos para o planejamento do desenvolvimento agrícola e rural. Florianópolis, 1978. v.I.

. Estrutura Agrária; evolução em Santa Catarina. 1969-1980. Florianópolis, 1984. 75p. (mimeog.)

. Colonização e evolução econômica; breves considerações - Oeste Catarinense. Florianópolis, 1990. 35p.

JOHNSON, R.A.; WICHERN, D.W. Applied multivariate statistical analysis. Englewood Cliffs: N.J. Prentice Hall, 1982. 589p. 
JOHNSTON, B.F.; MELLOR, J.W. The role of agriculture in economic develop ment. American Economic Review, 51, p.566-93, Sep. 1961.

KAGEYAMA, A.In:SILVA, J.G. Por um novo programa agrário. Anais do XXXI Congresso Brasileiro de Economia e Sociologia Rural. Brasília: SOBER, 19 93. v.2.

KAGEYAMA, A.; SILVA, J.G. da. Os resultados da modemização agrícola dos anos 70. Estudos econômicos, São Paulo, v.13, n.3, p.537-59. 1983.

KIYUNA, I. Modernização da agricultura e distribuição da renda no Estado de São Paulo, 1980. Piracicaba, 1989. 91 p. Dissertação de mestrado, ESALQ/ USP.

KUZNETS, S. Economic growth and income inequality. American Economic Review, Nashville, 45(1): 1-28, mar. 1955.

LAMOUNIER, B. (coord.). Determinantes políticos da política agrícola: um estudo de atores, demandas e mecanismos de decisão. IPEA: Estudos de Política agrícola, n.9, 1994. 58p.

LANDIM, J.R.M.; MONTEIRO, M.A. DE A. O processo de modemização da da agricultura e a estrutura produtiva da microrregião homogênea Serra de Jáboticabal, SP. R. Econ. Sociol. Rural, Brasília, 29(3):229-248, jul./set. 1991.

LEONE, E.T. Modernização e distribuição de renda na agricultura no Estado da Bahia em 1980. Piracicaba, 1988. Dissertação de mestrado-ESALQ/USP. 
MARQUES, P.V. Economia da integração vertical na avicultura de corte no Estado de São Paulo. Piracicaba, 1991. 133p. Tese de livre docência. ESALQ/USP.

MARTINE, G. A evolução recente da estrutura de produção agropecuária: algu mas notas preliminares. In: IPEA. Análise dos dados do Censo Agropecuário de 1985. Edição especial. Brasília: IPEA, 1987. p.63-88.

MESQUITA, O.V. et al. Modernização da agricultura brasileira. Revista Brasilei ra de Geografia, Rio de Janeiro, v.39, n.4, p.3-65. 1977.

MOLINAR, E.C.B. O crédito rural no Brasil: relação com a modernização da agricultura e aspectos distributivos. Piracicaba, 1984. 160p. Dissertação de mestrado-ESALQ/USP.

MOTTA, N.C. As conseqüências da implantação do projeto Aracruz celulose sobre a estrutura econômica da "região de linhares"-ES. Rio Claro, 1982. Dissertação de mestrado-UNESP.

MUELLER, C.A. A evolução recente da agropecuária brasileira segundo os dados dos Censos Agropecuários. In: IPEA. Análise dos dados do Censo Agropecuário de 1985. Edição especial. Brasília: IPEA, 1987. p.11 -41.

NICHOLLS, W.H. A economia agrícola brasileira: desempenho e política recente. In: Tecnologia e desenvolvimento agrícola. Rio de Janeiro: IPEA/INPES, 1975. Monografia n.17. p.47-87. 
PAIVA, R.M. Modemização e dualismo tecnológico na agricultura: uma reformulação. Pesquisa e Planejamento Econômico, Rio de Janeiro, 5(1):117-62. 1975.

. A agricultura no desenvolvimento econômico: suas limitações como fator dinâmico. Rio de Janeiro: IPEA, 1979. 218p. Série monográfica, n.30.

PASTORE, J.; ALVES, E.R.A. A reforma do sistema brasileiro de pesquisa agricola. In: Tecnologia e desenvolvimento agrícola. Rio de Janeiro: IPEA/ INPES, 1975. p.111-29. Monografia n.17.

PAULILO, M.I.S. A integração no sul de Santa Catarina. Rio de Janeiro, 1987. Tese de doutorado-UFRJ.

Produtor e agroindústria: consensos e dissensos.O caso de Santa Catarina. Florianópolis: Editora da UFSC, 1990. 182p.

PIAZZA, W.F. Atlas Histórico de Santa Catarina.Florianópolis: Secretaria de Educação e Cultura, 1970.

PRADO JÚNIOR, C. Contribuição para a análise da questão agrária no Brasil São Paulo: Brasiliense, 1979. 188p.

PREBISCH, R. O desenvolvimento econômico da América latina e seus principais problemas. Revista Brasileira de Economia, Rio de Janeiro, p.47-100, set. 1949. 
RANGEL, I. A questão agrária brasileira. In: Comissão de desenvolvimento econômico de Pernambuco. Recife, 1962. 74p.

. Questão agrária e agricultura. Encontro com a civilização brasileira, 7. 1979.

REZENDE, G.C. e GOLDIN, I. A agricultura brasileira na década de 80: crescimento numa economia em crise. Rio de Janeiro: Série IPEA 138, 1993.119p

SANTOS, R. F. dos. Presença de viéses de mudança técnica na agricultura brasileira. São Paulo: IPE/USP, 1986. 176p.

Análise crítica da interpretação neoclássica do processo de modernização da agricultura brasileira. Revista de Economia Política, São Paulo, v.8, n.3, p.131-48. 1988.

SCHUH, G. E. A modernização da agricultura brasileira: uma interpretação. In: Tecnologia e desenvolvimento agrícola. Rio de Janeiro: IPEA/INPES, 1975. p. 7-45. Monografia n. 17.

SCHUH, G. E.; BRANDÃO, A. S. P. The theory, empirical evidence, and debate debate on agricultural development issues in Latin America: a selective survey. In:A survey of agricultural economics literature. AAEA, 1990.(mimeog.)

SCHULTZ, T.W. The economic organization of agriculture. New York: Mac Graw-Hill Book Company, Inc., 1953. 
. Transforming traditional agriculture. New Haven: Yale University Press, 1964.

. O capital humano: investimentos em educação e pesquisa. Rio de Janeiro: Zahar, 1973. 250p.

SILVA, J.G. da. Pessoal ocupado: alguns resultados preliminares do Censo Agropecuário de 1985. In: IPEA. Análise dos dados do Censo Agropecuário de 1985, Edição especial. Brasília, 1987. p.42-62.

et al. Tecnologia e campesinato: o caos brasileiro. Revista de Economia Política, v.3, n.4. 1983.

. Por um novo programa agrário. In: Anais do XXXI Congresso Brasileiro de Economia e Sociologia Rural. Brasília: SOBER, 1993.v.2.

SMITH, G. W. A política agrícola brasileira, 1950-67. In: ARAÚJO, P. F. C. de; SCHUH, G.E. Desenvolvimento da agricultura. Estudo de casos. São Paulo: Pioneira, 1983. p.213-56.

SORJ, B. P. ; POMPERMAYER, M. ; CORADINI, O. C. Camponeses e agroindústria-Transformação social e representação política na avicultura brasi leira. Rio de Janeiro: Zahar Editores, 1982. 119p.

STERN, N. The determinants of growth. The Economic Journal, Great Britain, 101, p.122-33, Jan. 1991. 
Growth theories, old and new, and the role of agriculture in eco nomic development. 1994. 149p. (mimeografado)

TARSITANO, M.A.A. Análise da agricultura matogrossense, 1970/85: modernização, desconcentração da terra e mão-de-obra. São Paulo, 1990. 152p. Tese de doutorado-EAESP/FGV.

VERGARA FILHO, O. Desenvolvimento rural, condições de sustentabilidade, avaliação de impactos e auxílio à tomada de decisão tecnológica. In: Anais do XXXI Congresso Brasileiro de Economia e Sociologia Rural. Brasília, SO BER, 1993. v.2.

ZANCHET, M.S. Estrutura agrária, modernização e distribuição da renda na agropecuária catarinense em 1980. Piracicaba, 1990. 122p. Dissertação de mestrado-ESALQ/USP. 